Report No. BMI-1374

UC-25 Metallurgy and Ceramics (TID-4500, 14th Ed.)

Contract No. W-7405-eng-92

GAS-PRESSURE BONDING OF ZIRCALOY-CLAD FLAT-PLATE URANIUM DIOXIDE FUEL ELEMENTS

by

Stan J. Paprocki

Edwin S. Hodge

Donald C. Carmichael

Paul J. Gripshover

August 28, 1959

BATTELLE MEMORIAL INSTITUTE

505 King Avenue

Columbus 1 , Ohio 


\section{DISCLAIMER}

This report was prepared as an account of work sponsored by an agency of the United States Government. Neither the United States Government nor any agency Thereof, nor any of their employees, makes any warranty, express or implied, or assumes any legal liability or responsibility for the accuracy, completeness, or usefulness of any information, apparatus, product, or process disclosed, or represents that its use would not infringe privately owned rights. Reference herein to any specific commercial product, process, or service by trade name, trademark, manufacturer, or otherwise does not necessarily constitute or imply its endorsement, recommendation, or favoring by the United States Government or any agency thereof. The views and opinions of authors expressed herein do not necessarily state or reflect those of the United States Government or any agency thereof. 


\section{DISCLAIMER}

Portions of this document may be illegible in electronic image products. Images are produced from the best available original document. 


\section{TABLE OF CONTENTS}

\section{INTRODUCTION}

ABSTRACT . . . . . . . . . . . . . . . . . . . . . . . . . . . . . . . . . 1

BACKGROUND . . . . . . . . . . . . . . . . . . . . . . . . . . . . . . . . . 2

MATERIALS . . . . . . . . . . . . . . . . . . . . . . . . . . . . . . . . . 3

PRESSURE-BONDING EQUIPMENT . . . . . . . . . . . . . . . . . . . . . . . . . . . 4

CLEANING AND ASSEMBLY OF COMPONENTS . . . . . . . . . . . . . . . . . . . . . . . . . . . . 4

II. BASIC DEVELOPMENT STUDIES

GAS-PRESSURE-BONDING PROCESS . . . . . . . . . . . . . . . . . . . . . . . . . . . . . . .

EFFECT OF SURFACE PREPARATION . . . . . . . . . . . . . . . . . . . . . . . . . 14

Cold-Rolled Surfaces. . . . . . . . . . . . . . . . . . . . . . . . . . 14

Pickled Surfaces . . . . . . . . . . . . . . . . . . . . . . . . . . . 14

Miscellaneous Surfaces . . . . . . . . . . . . . . . . . . . . . . . 16

Machined and Belt-Abraded Surfaces . . . . . . . . . . . . . . . . . . 16

Beta-Heat-Treated Specimens . . . . . . . . . . . . . . . . . . . . . . . 16

CORE-CLADDING-REACTION STUDIES . . . . . . . . . . . . . . . . . . . . . . . . . 23

Specimens With Bare Cores . . . . . . . . . . . . . . . . . . . . . . . . . . 23

Specimens Containing Barrier Layers . . . . . . . . . . . . . . . . . . . . . . . 27

Graphite Barrier . . . . . . . . . . . . . . . . . . . . . . . . . . . . 27

Chromium Barrier . . . . . . . . . . . . . . . . . . . . . . . . . . . 32

Iron Barrier . . . . . . . . . . . . . . . . . . . . . . . . . . . . . 33

Nickel Barrier . . . . . . . . . . . . . . . . . . . . . . . . . . . . 33

Miscellaneous Barriers . . . . . . . . . . . . . . . . . . . . . . . . . . 33

III. DEVELOPMENT OF PROCESS FOR GAS-PRESSURE BONDING OF FUEL ELEMENTS UTILIZING PROTECTIVE CONTAINERS

TEST PROCEDURES . . . . . . . . . . . . . . . . . . . . . . . . . . . 38

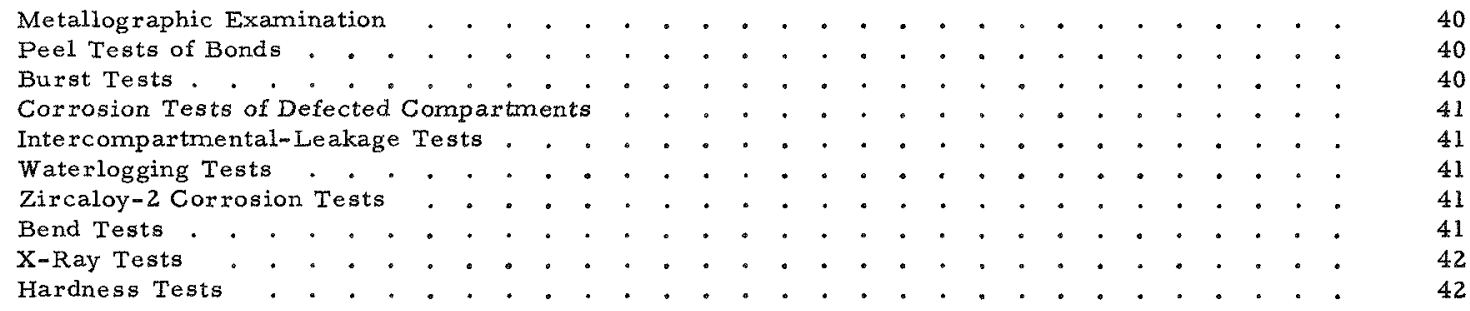

TEST RESULTS . . . . . . . . . . . . . . . . . . . . . . . . . . . . . . . . 42

General Evaluation . . • . . . . . . • . . . . . . . . . . . 42

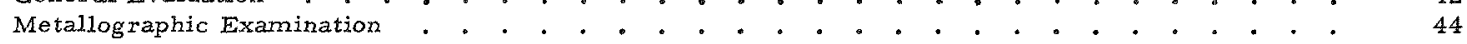

Peel Tests of Bonds . . . . . . . . . . . . . . . . . . . . . . . . . . . 44

Bend Tests . . . . . . . . . . . . . . . . . . . . . . . . . . . . . 48

Corrosion Tests of Purposely Defected Compartments . . . . . . . . . . . . . . . 55

Burst Tests. . . . . . . . . . . . . . . . . . . . . . . . . . . 61

Intercompartmental-Leakage Tests . . . . . . . . . . . . . . . . . . . . . . . 65

Waterlogging Tests . . . . . . . . . . . . . . . . . . . . . . . . . . .67

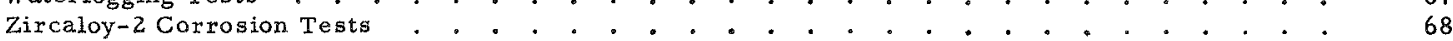

Evaluation of Gas-Pressure-Bonded 3-Ft-Long Fuel Element . . . . . . . . . . . . . . . 68

Investigation of Bonding Fuel Elements Prepared With Pure Zircaloy Components . . . . . . . . . 70 


\section{TABLE OF CONTENTS}

(Continued)

Page

IV. GAS-PRESSURE BONDING OF EDGE-WELDED ELEMENTS

PRELIMINARY STUDIES OF EDGE-WELDED ELEMENTS . . . . . . . . . . . . . . . . . . . . . . . 74

Specimens With One-Piece Punched Picture Frames . . . . . . . . . . . . . . . . . . . 74

Specimens With Piece-Component Picture Frames . . . . . . . . . . . . . . . . . . . . 76

GAS-PRESSURE BONDING OF EDGE-WELDED ELEMENTS FOR PROCESS DEVELOPMENT . . . . . . . . 81

Preparation of Elements . . . . . . . . . . . . . . . . . . . . . . . . . . . . 81

Test Procedures. . . . . . . . . . . . . . . . . . . . . . . . . . . . . . . 85

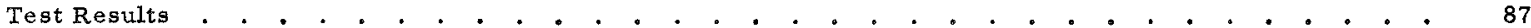

General Evaluation . . . . . . . . . . . . . . . . . . . . . . . . . . 87

Analyse of Cladđing . . . . . . . . . . . . . . . . . . . . . . . . . . . . 90

Intercompartmental-Leakage Tests and Corrosion Tests of Purposely Defected Compartments . . . 92

Burst Tests of Compartments . . . . . . . . . . . . . . . . . . . . . . 95

Metallographic Examination . . . . . . . . . . . . . . . . . . . . . . 99

V. SUMMARY AND CONCLUSIONS

ACKNOWLEDGMENT . . . . . . . . . . . . . . . . . . . . . . . . . 105

REFERENCES •. . . . . . . . . . . . . . . . . . . . . . . . . . . . . . 105 


\title{
GAS-PRESSURE BONDING OF ZIRCALOY-CLAD FLAT-PLATE URANIUM DIOXIDE FUEL ELEMENTS
}

\author{
Stan J. Paprocki, Edwin S. Hodge, Donald C. Carmichael, \\ and Paul J. Gripshover
}

A solid-state bonding technique involving the use of gas pressure at elevated temperatures was investigated for the preparation of compartmented Zircaloy-clad flat-plate uranium dioxide fuel elements. 'These investigations involved development of methods for the surface preparation and assembly of fuel-element components for bonding, determination of optimum bonding parameters, development of barrier coatings for uranium dioxide to prevent reaction with Zircaloy, and extensive testing and evaluation of the bonded fuel elements. During the course of this work, the process was continually modified and refined in an effort to improve the quality of the bonded element and decrease the cost of fabrication.

The surface-preparation studies indicated that satisfactory bonding could be obtained consistently with both machined and belt-abraded components. Belt abrasion is more economical and was used as the standard technique in the development phases of the program. Initially the elements were assembled into a stainless steel or Ti-Namel envelope which was evacuated and sealed prior to bonding. Later studies showed that the quality of bonded elements could be improved and process costs decreased by edge welding the Zircaloy components to form a gastight assembly that was then bonded without use of a protective envelope. Further cost reductions were incorporated into the process by the use of piece Zircaloy components to form the picture frame.

Optimum bonding with a minimum core-to-cladding reaction was achieved by pressure bonding at 1500 to $1550 \mathrm{~F}$ for $4 \mathrm{hr}$ using a helium gas pressure of 10,000 psi. A postbonding heat treatment for $5 \mathrm{~min}$ at $1850 \mathrm{~F}$ in a salt bath promoted additional grain growth at the bond interface during the alpha-to-beta transformation.

Barrier layers of graphite, chromium, iron, molybdenum, nickel, niobium, palladium, and various oxides were investigated to prevent reaction between the $\mathrm{UO}_{2}$ core and Zircaloy cladding. Graphite, in the form of a sprayed and buffed coating, and chromium were found to be relatively effective barriers. The graphite coating was easy to apply and less expensive than a chromium electroplate. 


\section{INTRODUCTION}

\section{BACKGROUND}

A. Zircaloy-clad flat-plate uranium dioxide fuel element is being considered for use in the PWR. $(1,2,3)$ The oxide is spaced in compartments separated by Zircaloy webs designed to isolate failures if a cladding rupture occurs. The compartments also function as individual pressure chambers for the containment of fission gas.

Gas-pressure bonding is one of the methods that is being studied for the fabrication of these elements. In this method, the Zircaloy components are fabricated to final size prior to bonding. The oxide cores are inserted into a compartmented Zircaloy picture frame which is then covered with Zircaloy cladding plates. Final assembly of the components for pressure bonding can be accomplished by two different methods. One method consists of as sembling the components into an envelope which is then evacuated and sealed. The other method involves fusion welding of the edges of the Zircaloy cladding plates to the Zircaloy picture frame prior to evacuation, sealing, and pressure bonding in an autoclave. In the first method, the differential gas pressure between the high-pressure helium and the inside of the sealed envelope brings the components into intimate contact so that diffusion can occur to form a solid-state bond. In the second method the gas pressure is exerted directly on the Zircaloy components, and the same end result is obtained. Bonding is done above the recrystallization temperature of the Zircaloy. The temperature and pressure are maintained for a sufficient length of time to produce a solid-phase bond at all interfaces of the components.

The gas-pressure-bonding process is well suited to the bonding of these elements because bonding is accomplished without deformation of the uranium dioxide. It takes place with a small amount of deformation of the Zircaloy; the amount is only that necessary to close all of the void space and obtain intimate contact between all components. This is desirable from a heat-transfer standpoint, but it may be undesirable if void space is required for fission-gas containment.

The pressure-bonding parameters of temperature, time, and pressure may be varied over an extensive range, limited only by the design specifications of the equipment. The most satisfactory conditions for a particular application depend upon the materials and configuration to be used. It was necessary to determine pressurebonding parameters suitable for bonding of these elements.

Since the pressure-bonding process involves only slight deformation, the method used to surface condition the Zircaloy has a significant influence on the bond quality. Surface condition is, of course, important in all bonding processes. It is more critical for gas-pressure bonding because extensive deformation is not available to disrupt contaminating layers and cause recrystallization and grain growth. Therefore, a study was conducted to determine the effect on bond quality of various methods of surface finishing of Zircaloy.

Zircaloy begins to react with uranium dioxide at about $1100 \mathrm{~F}^{(4)}$ At the pressurebonding temperature of $1500 \mathrm{~F}$, extensive reaction occurs. The reaction products possess poor corrosion resistance in pressurized water, and, in service, defects in the

(1) References at end. 
cladding would possibly result in excessive corrosion and bulging or rupture of the compartments. In efforts to overcome this problem, barrier layers were investigated, and several were found to minimize or prevent the reaction between the uranium dioxide and Zircaloy.

The program described in this report consisted of a study of pressure-bonding conditions of temperature, time, and pressure, a study of bonding-surface preparation, and a study of core-to-cladding reaction and of barrier layers to prevent the reaction. These basic studies were followed by a process-development study of elements bonded in containers, preliminary studies of bonding edge-welded elements with one-piece picture frames and then piece-component picture frames, and a process-development study of bonding edge-welded elements having piece-component picture frames.

\section{MATERIALS}

Both the reactor-grade Zircaloy -2 and the uranium dioxide fuel material utilized in this work were supplied by the Bettis Atomic Power Division of Westinghouse Electric Corporation. Initially, the Zircaloy was inert-atmosphere arc melted. Later vacuummelted material was supplied by Bettis as it was desirable to bond reference material. The fuel core materials were high-density $\mathrm{UO}_{2}-\mathrm{Al}_{2} \mathrm{O}_{3}$ or $\mathrm{UO}_{2}$.

Most of the Zircaloy cladding stock supplied by Bettis was already fabricated to final thickness. The Zircaloy stock fabricated by Battelle was initially hot rolled at $1450 \mathrm{~F}$ from a helium atmosphere; however, to reduce oxidation, the rolling temperature was ultimately lowered to $1150 \mathrm{~F}$. (5)

Barrier layers of iron, molybdenum, nickel, niobium, and palladium were obtained from the purest foil available. Chromium, iron, and nickel were also used in the form of an electroplated coating on the core material, and, to do this, methods for electroplating chromium, iron, and nickel on uranium dioxide were developed. Iron and nickel were plated over a $0.003-\mathrm{mil}$ conductive layer of silver, and chromium was plated over a flash electroplate of iron or nickel applied over the conductive silver layer. Cores were also plated with electroless or Kanigen nickel by the Kanigen Division of the American General Transportation Company. A barrier of graphite was applied by brushing the uranium dioxide with Neolube, a suspension of graphite in alcohol, followed by $750 \mathrm{~F}$ vacuum drying, or by spraying the cores with Aquadag, a suspension of graphite in water, followed by vacuum drying and buffing.

The gastight envelopes were prepared from Type 304 stainless steel or Ti-Namel sheet. Ti-Namel spacers were inserted between the container and the Zircaloy cladding plates. Either these spacers were chromium plated or 0.005-in.-thick stainless steel shims were inserted between the Zircaloy and Ti-Namel to minimize diffusion of iron into the Zircaloy. 
PRESSURE-BONDING EQUIPMENT

The specimens, except for those in the final process-development study of edgewelded elements, were pressure bonded in a 9-in. -ID cold-wall autoclave obtained from the Autoclave Engineering Company. A schematic drawing of the autoclave is shown in Figure 1. The vessel was machined from a billet of Type 410 stainless steel and is equipped with modified Bridgeman closures. The large-scale edge-welded elements were bonded in a similar 14-in. -ID autoclave. These autoclaves are described elsewhere in the literature. (6)

A resistance heater was located in the center of the autoclave, and the specimens to be bonded were loaded within this heater. Several thermocouples were spaced along the length of the specimens to record the temperature gradient. All of the void space in the autoclave was tightly packed with insulating material to minimize heat,transfer to the wall of the autoclave, which otherwise would be extremely rapid because of the high gas pressure. At a temperature of $1550 \mathrm{~F}$ and a helium pressure of $10,000 \mathrm{psi}$, utilizing a 3-in.-diameter heater, it was possible to operate with a maximum outside-wall temperature of the 9-in. -ID vessel below $300 \mathrm{~F}$ without benefit of a cooling liner. The 14-in. -ID autoclave has a spiral-grooved liner incorporated in the inside vessel walls through which water can be circulated to keep the outer body cool. During the pressurebonding cycle, both the temperature and pressure were attained in about $1 \mathrm{hr}$. These conditions were then maintained for the specified time, usually 2 to $5 \mathrm{hr}$.

Helium was used for pressurizing in all experiments, but other inert gases such as argon can also be used. To minimize contamination, the autoclave was evacuated and purged prior to pressure bonding.

\section{CLEANING AND ASSEMBLY OF COMPONENTS}

The Zircaloy components were cleaned by a standard process involving degreasing in alcohol, followed by detergent washes and cold- and hot-water rinses. Fuel cores were carefully inserted into the compartments of the picture frame, the cladding plates were applied, and the assembled components were then either sealed in a stainless steel or Ti-Namel container or edge welded. For the specimens bonded in a container, the Ti-Namel spacers were inserted between the Zircaloy cladding plates and the container to facilitate decanning after pressure bonding. Either these were chromium plated or a stainless steel shim was used to minimize diffusion of iron into the Zircaloy. The components for an element to be bonded in a container using a one-piece punched picture frame are shown ready for assembly in Figure 2.

The stainless steel or Ti-Namel containers were prepared by bending light-gage sheet on a form block, and welding the edges of the sheet to form the container. A swastika container design was used to facilitate welding and promote an even distribution of pressure along the edges of the specimen. An end plate of similar material and an evacuation tube were welded in one end. After the fuel-element components were inserted from the other end, the final end plate was welded in position. Leak testing of the assembly was accomplished by pressurizing with helium followed by helium detection. The assembly was then evacuated, sealed, and pressure bonded. After bonding, 
the ends of the container were cut off and the container and spacers were manually stripped from the element.

Specimens were also bonded without use of an envelope. The fuel-element components were assembled and the edges of the Zircaloy were fusion welded to form a gastight assembly. To avoid contamination of the bonding surfaces, the elements were clamped between copper cooling blocks and welded in a helium-atmosphere. Initially, a small area at one end of the element was not sealed in the weld in order to avoid entrapment of helium inside the element. After welding, the element was evacuated through this opening and the final closure was made by welding in air. It was considered that a small amount of air inside the element, unlike helium, might be absorbed by the Zircaloy during pressure bonding without adverse effects. Later, techniques were developed for evacuating these edge-welded elements during final sealing. The picture frames for these elements were assembled from strip components. 


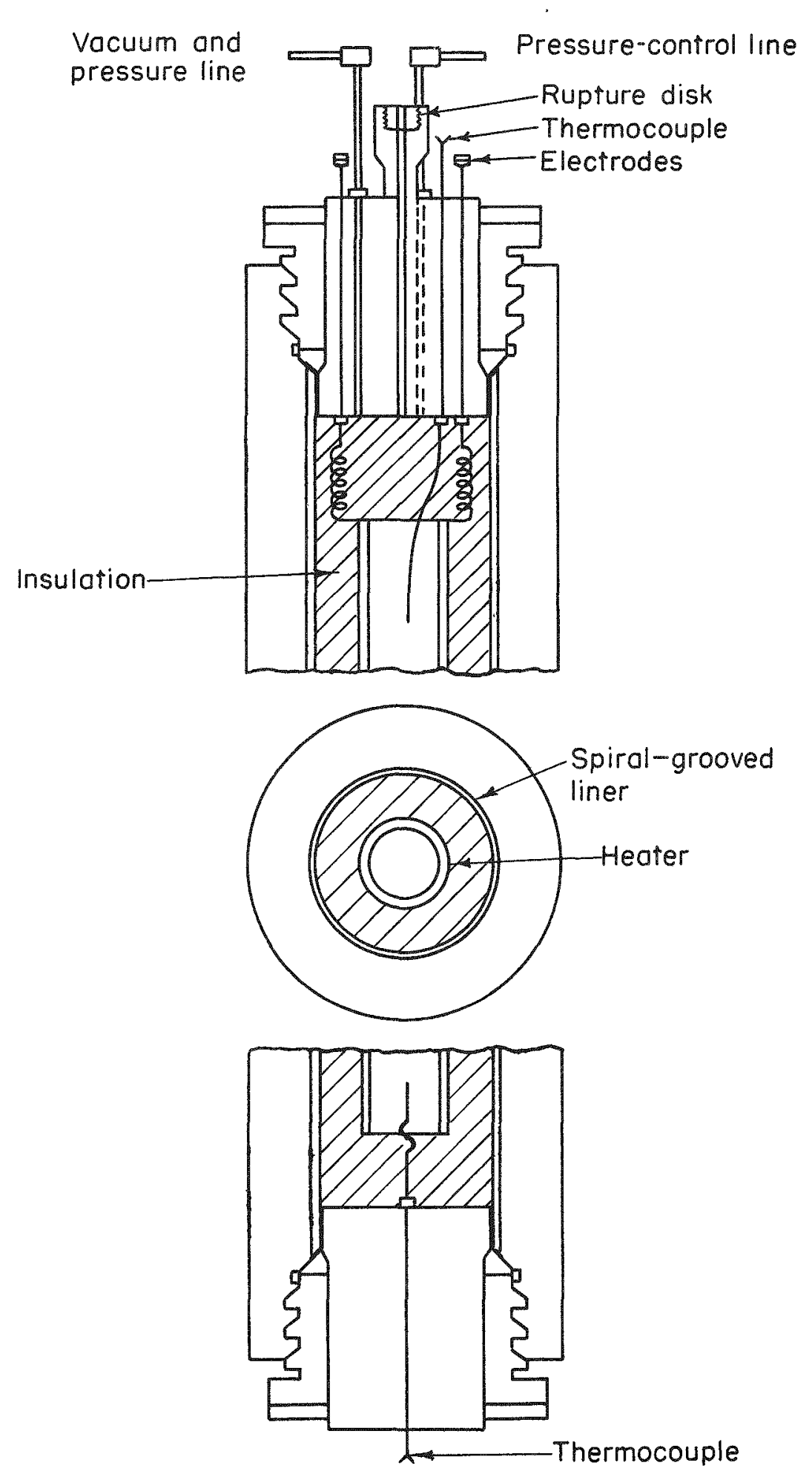

A 27437

FIGURE 1. SECTIONAL VIEW OF A HIGH-PRESSURE COLD-WALL AUTOCLAVE 


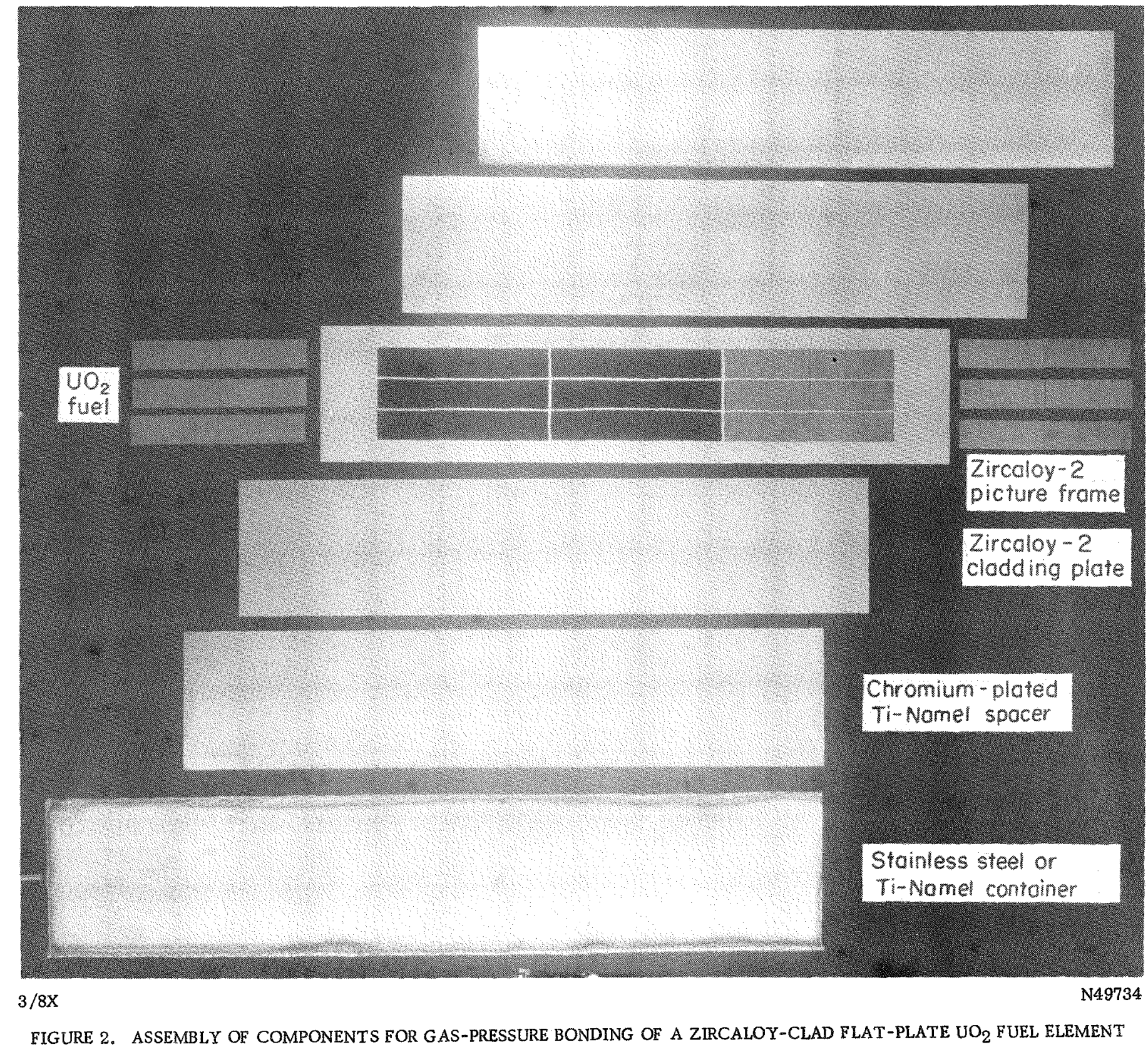

FIGURE 2. ASSEMBLY OF COMPONENTS FOR GAS-PRESSURE BONDING OF A ZIRCALOY-CLAD FLAT-PLATE UO 2 FUEL ELEMENT 


\section{BASIC DEVELOPMENT STUDIES}

\section{GAS-PRESSURE-BONDING PROCESS}

The pressure-bonding operation was conducted at a temperature and gas pressure which produced sufficient plastic flow to achieve intimate contact between the components. After this contact was established, the temperature and pressure were maintained until a solid-phase bond was formed. A study was conducted in which the pressure-bonding parameters of temperature, time, and pressure were varied in order to determine the optimum bonding conditions. Pressures of 5,000 and 10,000 psi, times of 2 and $4 \mathrm{hr}$, and temperatures from 1200 to $1600 \mathrm{~F}$ were investigated.

Previous studies had shown that the surface condition of the Zircaloy hada pronounced effect on bonding. In the most promising surface treatments the components were: (1) belt abraded; (2) pickled with a solution consisting of 5 parts HF (by volume), 45 parts $\mathrm{HNO}_{3}$, and 50 parts water, followed by a sulfuric acid etch; and (3) pickled with hydrofluoric acid solution and then rinsed in a boiling sodium hydroxide solurion. The specimens utilized to study pressure-bonding parameters with these surface preparations consisted of two surface-prepared flat plates of arc-melted Zircaloy- 2 and contained no cores. The surface-prepared plates and accompanying Ti-Namel spacers were inserted in Ti-Namel envelopes for pressure bonding. After bonding and removal of the Ti-Namel containers and spacers, the specimens were heat treated at $1850 \mathrm{~F}$ for $5 \mathrm{~min}$ in a barium chloride salt bath and rapidly cooled in a flow of helium. For most of the conditions, additional specimens were prepared without the beta-phase heat treatment for examination in the as-bonded condition. The heat treatment promoted additional grain growth across the original bond interface during the alpha-beta phase transformation. It was found that many of the as-bonded specimens exhibited only 5 to 60 per cent grain growth across the original interface. These same specimens after a beta treatment of $5 \mathrm{~min}$ at $1850 \mathrm{~F}$ would usually exhibit 70 to 95 per cent grain growth. The specimens in this study were evaluated by metallographic examination, peel tests of bonds, bend tests, tensile tests, and composition analyses.

The results of the metallographic bond evaluation of the as-pressure-bonded samples are presented in Table 1 and of the beta-heat-treated samples in Table 2. In the evaluation of the pressure-bonded specimens it was desirable to establish a definite means of comparison of the bonds in each of the specimens. To do this, the quality of the bonds as determined using a light microscope with polarized light was designated as Type A, B, or C. The original interface of a Type A bond is not visible metallographically; there is complete grain growth across the entire original bond interface with no visible contamination or voids at the bond. An area of a bond classified as Type $B$ has grain growth across the bond interface, but slight contamination or voids are visible along the original bond line. An area of a bond which does not demonstrate grain growth across the bond interface is classified as Type C. Typical bonds of each type are shown in Figure 3 for specimens from this series both with and without the beta heat treatment. Under bright field and low magnification, it appears that the inclusions observed in these specimens illustrated in Figure 3 are present in a somewhat continuous manner in the bond line; however, electron-microscopy studies did not detect the presence of inclusions in these specimens. The bond interfaces, as evidenced by electron microscopy, seemed to contain fine voids, which were not interconnected or 
TABLE 1. METALLOGRAPHIC EVALUATION OF SPECIMENS PREPARED USING VARIOUS PRESSURE-BONDING CONDITIONS

Specimens not beta heat treated.

\begin{tabular}{|c|c|c|c|c|c|c|}
\hline \multirow[b]{3}{*}{ Surface Preparation } & \multicolumn{3}{|c|}{ Pressure-Bonding Conditions } & \multirow{2}{*}{\multicolumn{3}{|c|}{$\begin{array}{l}\text { Bond Evaluation, percentage of bond } \\
\text { interface occupied by each type of bond }\end{array}$}} \\
\hline & Temperature, & Time, & Pressure, & & & \\
\hline & $F$ & & psi & Type A & Type B & Type C \\
\hline \multirow[t]{8}{*}{ Belt abraded } & 1500 & 4 & 10,000 & 70 & 30 & -- \\
\hline & 1500 & 4 & 5,000 & 5 & 60 & 35 \\
\hline & 1450 & 4 & 10,000 & 10 & 70 & 20 \\
\hline & 1400 & 4 & 10,000 & -- & 40 & 60 \\
\hline & 1350 & 4 & 10,000 & -- & 60 & 40 \\
\hline & $1350^{(a)}$ & 4 & 10,000 & - & 40 & 60 \\
\hline & 1200 & 4 & 10,000 & -- & 10 & 90 \\
\hline & $1200^{(a)}$ & 4 & 10,000 & - & 5 & 95 \\
\hline \multirow[t]{3}{*}{$\mathrm{HE}$ pickle, $\mathrm{NaOH}$ rinse } & 1500 & 4 & 10,000 & $\ldots$ & 94 & 1 \\
\hline & 1450 & 4 & 10,000 & -- & 5 & 95 \\
\hline & 1400 & 4 & 10,000 & -- & -- & 100 \\
\hline \multirow[t]{3}{*}{$\mathrm{HF}$ pickle, $\mathrm{H}_{2} \mathrm{SO}_{4}$ etch } & 1500 & 4 & 10,000 & -- & 5 & 95 \\
\hline & 1450 & 4 & 10,000 & -- & 40 & 60 \\
\hline & 1400 & 4 & 10,000 & $-\infty$ & 10 & 90 \\
\hline
\end{tabular}

(a) The assembled specimens were heared $4 \mathrm{hr}$ at $1650 \mathrm{~F}$ after evacuation and sealing and before pressure bonding.

TABLE 2. MET ALLOGRAPHIC EVALUATION OF SPECIMENS PREPARED USING V ARIOUS PRESSURE - BONDING CONDITIONS

Specimens heat treated at $1850 \mathrm{~F}$ for $5 \mathrm{~min}$ in a salt bath.

\begin{tabular}{|c|c|c|c|c|c|c|}
\hline \multirow[b]{3}{*}{ Surface Preparation } & \multicolumn{3}{|c|}{ Pressure-Bonding Conditions } & \multirow{2}{*}{\multicolumn{3}{|c|}{$\begin{array}{l}\text { Bond Evaluation, percentage of bond } \\
\text { interface occupied by each type of bond }\end{array}$}} \\
\hline & Temperature, & Time, & Pressure, & & & \\
\hline & F & hr & psi & Type A & Type B & Type C \\
\hline \multirow[t]{10}{*}{ Belt abraded } & 1550 & 4 & 10,000 & 80 & 20 & - \\
\hline & 1500 & 4 & 10,000 & 80 & 20 & -- \\
\hline & 1500 & 4 & 5,000 & 75 & 25 & -- \\
\hline & 1500 & 2 & 10,000 & 75 & 25 & $-\infty$ \\
\hline & 1450 & 4 & 10,000 & 100 & - & $-\infty$ \\
\hline & 1400 & 4 & 10,000 & 25 & 75 & $-\infty$ \\
\hline & 1350 & 4 & 10,000 & 30 & 70 & - \\
\hline & $1350^{(a)}$ & 4 & 10,000 & 5 & 55 & 40 \\
\hline & 1200 & 4 & 10,000 & 5 & 50 & 45 \\
\hline & $1200^{(a)}$ & 4 & 10,000 & -- & 30 & 70 \\
\hline \multirow[t]{5}{*}{ HF pickle, NaOH rinse } & 1500 & 4 & 10,000 & 90 & 10 & $-\infty$ \\
\hline & 1500 & 4 & 5,000 & 5 & 90 & 5 \\
\hline & 1450 & 4 & 10,000 & 10 & 90 & $-\infty$ \\
\hline & 1400 & 4 & 10,000 & 5 & 95 & - \\
\hline & 1350 & 4 & 10,000 & -- & 95 & 5 \\
\hline \multirow[t]{5}{*}{$\mathrm{HF}$ pickle, $\mathrm{N}_{2} \mathrm{SO}_{4}$ etch } & 1500 & 4 & 10,000 & 30 & 70 & $=-$ \\
\hline & 1500 & 4 & 5,000 & $-\infty$ & 10 & 90 \\
\hline & 1450 & 4 & 10,000 & 40 & 60 & -- \\
\hline & 1400 & 4 & 10,000 & 15 & 65 & 20 \\
\hline & 1350 & 4 & 10,000 & 1 & 99 & -- \\
\hline
\end{tabular}

(a) The assembled specimens were heated $4 \mathrm{hr}$ at $1650 \mathrm{~F}$ after evacuation and sealing and before pressure bonding. 

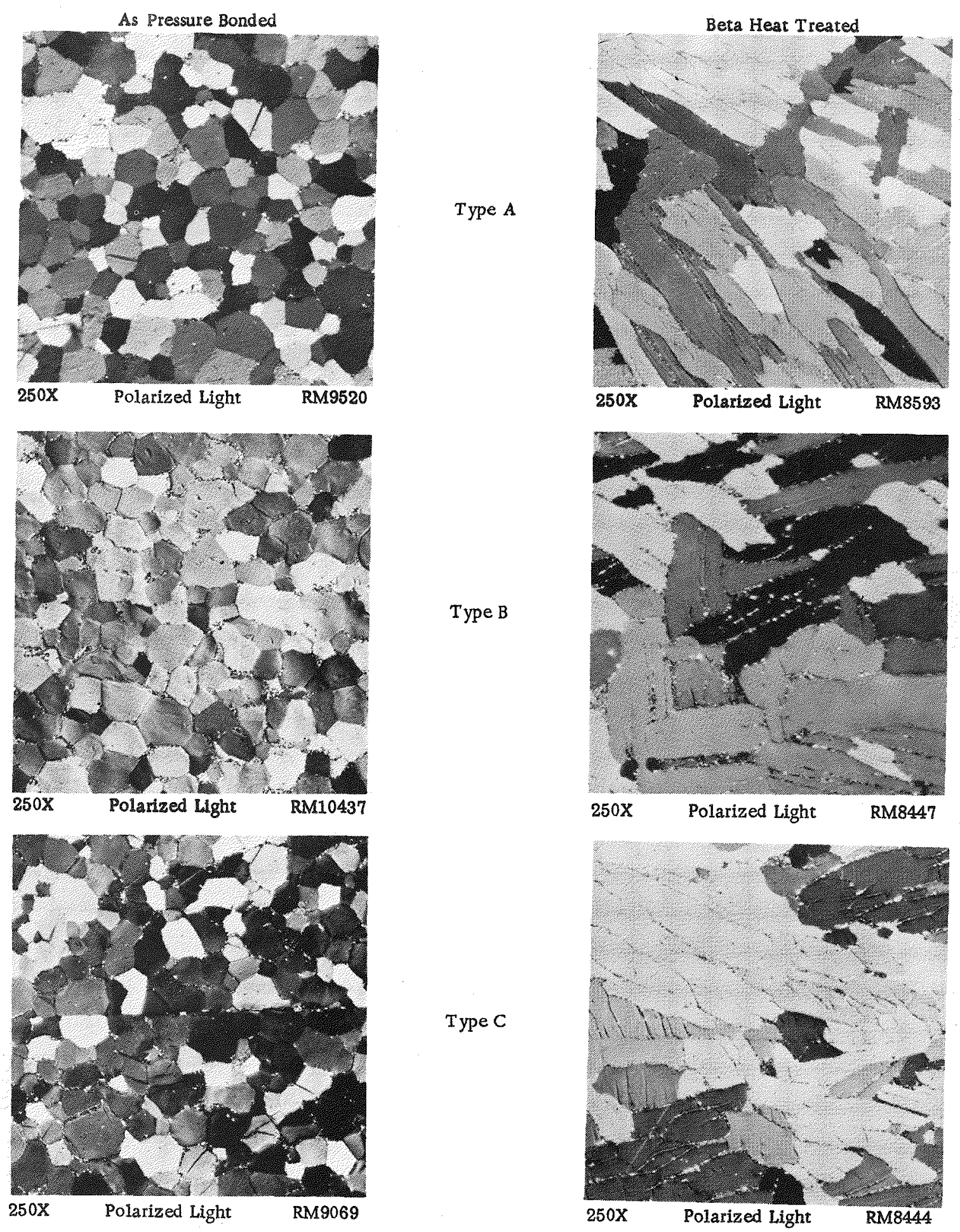

FIGURE 3. CLASSIFICATION OF BONDS AS TYPES A, B, AND C BY MET ALLOGRAPHIC EVALUATION

Type A - Grain growth across entire bond interface, no visible bond-line contamination or voids.

Type B - Grain growth across bond interface, slight bond-line contamination or voids visible.

Type C - No grain growth across bond interface, with or without visible bond-line contamination or voids. 
continuous. The preferential etch used to prepare the specimens for light microscopy may account for the inclusionlike appearance of the voids in the bond line.

The results of the metallographic study disclosed that as the bonding temperature was decreased, the consistency of the metallurgical bonds obtained also generally decreased. Temperatures in the range of 1450 to $1550 \mathrm{~F}$ yielded the most satisfactory bonds. It was found in one specimen bonded at $1600 \mathrm{~F}$ that the diffusion of iron from the spacers into the Zircaloy was excessive. A decrease in bond quality was noted for one specimen when the bonding pressure was reduced from 10,000 to 5,000 psi. Also, on the basis of one specimen, which was heat treated after bonding, the bonding time does not appear to be critical in the range of 2 to $4 \mathrm{hr}$; other studies have indicated this same result.

A comparison of Tables 1 and 2 shows that the amount of grain growth across the bond interface was markedly improved by the beta heat treatment. Bonds with incomplete grain growth across the interface still possessed good corrosion resistance and strength; however, they were considered unsatisfactory because the interface was suspected to be a plane of weakness. Therefore, the brief salt-bath treatment at $1850 \mathrm{~F}$ gave added assurance that a satisfactory bond was obtained.

Although this study was not designed to determine the optimum surface preparation for the bonding of Zircaloy, the data indicated that the belt-abraded surfaces produced the most consistent bonds for the various conditions tested. However, belt abrading had not been sufficiently investigated and standardized at the time these specimens were prepared to eliminate some inconsistencies in the results. The concurrent study made of belt abrading and other surface preparations is reported in the next section.

Several specimens to be bonded at 1200 and $1350 \mathrm{~F}$ were heat treated at $1650 \mathrm{~F}$ for $4 \mathrm{hr}$ after being evacuated and sealed and before being pressure bonded. It was desired to determine if this prior treatment would produce improved bonding due to solution of contaminants into the Zircaloy. Comparison of the results of the metallographic inspection of these specimens and specimens identical except for the $1650 \mathrm{~F}$ heat treatment before bonding revealed that no improvement had been obtained by including the additional treatment, as shown in Tables 1 and 2.

Bend tests, peel tests, and tensile tests were also made on a portion of the specimens bonded in this study to determine if cladding embrittlement had occurred during pressure bonding or beta heat treating and to test the strength of the bonds. The bend tests were conducted by using a bend-test die and bending samples through a 90-deg angle around successively smaller radii until failure occurred. The results of the se tests were expressed in terms of the $T$-value, which is equal to the radius of the die preceding the final die divided by the sample thickness. After bend testing, the samples were metallographically examined to determine if any separation of the bond had occurred. Tensile tests were performed using flat-plate tensile specimens in which the original bond interface ran longitudinally through the center of the specimen. In addition to obtaining strength and ductility properties, the samples were inspected for possible bond failures during testing. Reference specimens, prepared from the same base material, but not pressure bonded, were also tensile tested. In the peel tests, a small V-notch was filed in the specimen with the apex at the bond interface. A chisel was then driven into the notch to attempt to separate the bond. 
TABLE 3. RESULTS OF MECHANICAL TESTS OF PRESSURE-BONDED SPECIMENS

\begin{tabular}{|c|c|c|c|c|c|c|c|c|c|c|c|}
\hline \multirow[b]{2}{*}{ Specimen } & \multicolumn{3}{|c|}{ Pressure-Bonding Conditions } & \multirow[b]{2}{*}{$\begin{array}{c}\text { Surface } \\
\text { Preparation }\end{array}$} & \multirow{2}{*}{$\begin{array}{c}0.2 \text { Per Cent Offset } \\
\text { Yield Strength } \\
(0.04 \mathrm{In} . / \mathrm{In} . / \mathrm{Min}), \\
10^{3} \mathrm{psi}\end{array}$} & \multirow{2}{*}{$\begin{array}{l}\text { Elongation } \\
\text { in } 1 \mathrm{In.} \\
\text { per cent }\end{array}$} & \multirow{2}{*}{$\begin{array}{c}\text { Bond Strength } \\
\text { During } \\
\text { Tensile Test }\end{array}$} & \multirow[b]{2}{*}{$\begin{array}{c}\text { Bend T'est, } \\
\text { T-value }\end{array}$} & \multirow{2}{*}{$\begin{array}{c}\text { Bond Strength } \\
\text { in } \\
\text { Bend Test }\end{array}$} & \multirow{2}{*}{$\begin{array}{l}\text { Bond Strength } \\
\text { in } \mathrm{V} \text {-Notch } \\
\text { Peel Test }\end{array}$} & \multirow{2}{*}{$\begin{array}{c}\text { Rockwell B } \\
\text { Hardness } \\
\text { (100-Kg Load) }\end{array}$} \\
\hline & $\begin{array}{c}\text { Time, } \\
\mathrm{hr}\end{array}$ & $\begin{array}{c}\text { Temperature } \\
\text { F }\end{array}$ & $\begin{array}{l}\text { Pressure, } \\
\text { psi }\end{array}$ & & & & & & & & \\
\hline
\end{tabular}

Specimens Heat Treated at $1850 \mathrm{~F}$ for $5 \mathrm{Min}$ After Pressure Bonding

\begin{tabular}{|c|c|c|c|c|c|c|c|c|c|c|c|}
\hline STD-1 & \multicolumn{4}{|c|}{ Reference material; beta heat treated } & 56.3 & 21 & -- & 2.70 & $\ldots$ & -. & 85 \\
\hline STD-2 & \multicolumn{4}{|c|}{ Reference material; beta heat treated } & 55.2 & 22 & -- & 2.70 & - & -- & 84 \\
\hline $\mathrm{FP}-1$ & 4 & 1550 & 10,000 & Abraded & 51.0 & 24 & Good & 3.05 & Good & Good & 81 \\
\hline $\mathrm{FP}-2$ & 4 & 1500 & 10,000 & $\mathrm{HF} ; \mathrm{NaOH}$ & 53.5 & 24 & Good & 3.06 & Good & Good & 81 \\
\hline FP-3 & 4 & 1500 & 10.000 & $\mathrm{HF} ; \mathrm{H}_{2} \mathrm{SO}_{4}$ & 50.0 & 23 & Good & 2.34 & Good & Good & 81 \\
\hline FP -4 & 4 & 1450 & $\begin{array}{l}10,000 \\
10,000\end{array}$ & Abraded 4 & 50.5 & 24 & Good & 2.32 & Good & Good & 81 \\
\hline FP-5 & 4 & 1450 & 10,000 & $\mathrm{HF} ; \mathrm{NaOH}$ & 53.9 & 24 & Good & 2.34 & Good & Good & 82 \\
\hline FP-6 & 4 & 1450 & 10,000 & $\mathrm{HF} ; \mathrm{H}_{2} \mathrm{SO}_{4}$ & 53.9 & 24 & Good & 2.34 & Good & Good & 81 \\
\hline FP -7 & 4 & 1450 & 10,000 & Abraded & 52.9 & 24 & Good & 2.33 & Good & Good & 82 \\
\hline FP-8 & 4 & 1400 & 10,000 & $\mathrm{HF}_{3} \mathrm{NaOH}$ & 51.1 & 23 & Good & 1.70 & Good & Good & 84 \\
\hline FP-9 & 4 & 1400 & 10,000 & $\mathrm{HF} ; \mathrm{H}_{2} \mathrm{SO}_{4}$ & 51,1 & 23 & Good & 2.36 & Good & Good & 83 \\
\hline $\mathrm{FP}-10$ & 4 & 1500 & 5,000 & Abraded & 52.1 & 23 & Good & 2.36 & Good & Good & 82 \\
\hline FP-11 & 4 & 1500 & 5,000 & $\mathrm{HF}^{\prime} \mathrm{NaOH}$ & 53.9 & 22 & Good & 1.54 & Good & Good & 82 \\
\hline FP-12 & 4 & 1500 & 5,000 & $\mathrm{HF} ; \mathrm{H}_{2} \mathrm{SO}_{4}$ & 52.3 & 21 & Good & 1.57 & Good & Good & 81 \\
\hline
\end{tabular}

Specimens Not Heat Treated After Pressure Bonding

\begin{tabular}{|c|c|c|c|c|c|c|c|c|c|c|c|}
\hline STD -3 & \multicolumn{4}{|c|}{ Reference material; not beta heat treated } & 44.8 & 28 & $-\infty$ & 2.70 & $-\infty$ & - & 87 \\
\hline STD -4 & \multicolumn{4}{|c|}{ Reference material; not beta heat treated } & 43.8 & 28 & -- & 2.70 & -- & - & 88 \\
\hline $\mathrm{FP}-4 \mathrm{~A}$ & 4 & 1450 & 10,000 & Abraded & 40.9 & 25 & Failed & 1.50 & Failed & Failed & 86 \\
\hline $\mathrm{FP}-8 \mathrm{~A}$ & 4 & 1400 & 10,000 & $\mathrm{HF} ; \mathrm{NaOH}$ & 42.0 & 25 & Failed & 1.50 & Failed & Failed & 87 \\
\hline
\end{tabular}


The results of these mechanical tests are given in Table 3. The tensile and bend tests showed the Zircaloy -2 in the specimens to be strong and ductile after pressure bonding and beta heat treating. There was not considered to be a significant difference between the physical properties of the pressure-bonded material and the reference material. Separation resulting from the bend and tensile tests was not observed in any of the bonds which had been beta heat treated. Neither could any of the se bonds be caused to fail during the $V$-notch peel tests. However, the two samples tested which had not been heat treated ruptured at the bond.

Vacuum-fusion gas analyses of some of the specimens were performed by standard techniques to determine the amount of oxygen and hydrogen absorbed by the Zircaloy during pressure bonding and heat treating. These results are presented in Table 4. Although there is considerable variability in the data, there apparently was an increase in the hydrogen content of the Zixcaloy during pressure bonding and also during beta treating in the salt bath. These hydrogen contents did not appear to affect the ductility of these thick specimens, however. There did not appear to be a significant increase in the oxygen content as a result of either of these operations.

The Ti-Namel spacers used for these specimens were flash plated with chromium in an attempt to prevent diffusion of iron into the Zircaloy-2. No diffusion was metallographically observed in these specimens and the tensile properties also indicated no contamination of the Zircaloy by the spacers. Stainless steel foil 0.005 in. thick between the spacers and cladding was also found to successfully prevent reaction. The chromium plating was preferred and was used for the later process-development study because of easier assembly of the specimens. However, in the process-development study it was found that nonuniform chromium coatings permitted diffusion and stainless steel barriers gave better results.

As a result of this study of pressure-bonding parameters, a bonding cycle was selected that consisted of pressure bonding at $1450 \mathrm{~F}$ to $1550 \mathrm{~F}$ for 2 to $4 \mathrm{hr}$ with a helium pressure of 10,000 psi, which may be followed by heat treating at $1850 \mathrm{~F}$ for $5 \mathrm{~min}$ in a barium chloride salt bath.

TABLE 4. VACUUM-FUSION GAS ANALYSES OF PRESSURE-BONDED ZIRCALOY -2 SPECIMENS

\begin{tabular}{|c|c|c|c|c|}
\hline \multirow[b]{2}{*}{ Marerial } & \multirow{2}{*}{\multicolumn{2}{|c|}{ Condition }} & \multicolumn{2}{|c|}{ Analysis, ppm } \\
\hline & & & Oxygen & Hydrogen \\
\hline \multirow[t]{5}{*}{ Zircaloy -2 plate } & \multirow[t]{2}{*}{ As received } & & 1110 & 24 \\
\hline & & & 1440 & 25 \\
\hline & \multirow{3}{*}{ Heat treated at $1850 \mathrm{~F}$ in $\mathrm{BaCl}_{2}$ salt bath for: } & & 1085 & 35 \\
\hline & & & 1690 & 52 \\
\hline & & & 1150 & 66 \\
\hline \multirow{4}{*}{$\begin{array}{l}\text { Zircaloy }-2 \text { plates etched } \\
\text { with HF solution and } \\
\text { pressure bonded }\end{array}$} & \multicolumn{2}{|l|}{ Pressure bonded $4 \mathrm{hr}$ at $1400 \mathrm{~F}$ and $10,000 \mathrm{psi}$} & 1050 & 74 \\
\hline & \multirow[t]{3}{*}{ Bonded and heat treated at $1850 \mathrm{~F}$ in $\mathrm{BaCl}_{2}$ salt bath for: } & $3 \min$ & 812 & 82 \\
\hline & & $5 \min$ & 1230 & 73 \\
\hline & & $10 \mathrm{~min}$ & 1430 & 116 \\
\hline \multirow{5}{*}{$\begin{array}{l}\text { Zircaloy - } 2 \text { plates belt } \\
\text { abraded and pressure } \\
\text { bonded }\end{array}$} & \multirow{5}{*}{$\begin{array}{l}\text { Pressure bonded } 4 \mathrm{hr} \text { at } 1450 \mathrm{~F} \text { and } 10,000 \mathrm{psi} \\
\text { Bonded and heat treated at } 1850 \mathrm{~F} \text { in } \mathrm{BaCl}_{2} \text { salt bath for: }\end{array}$} & & 927 & 96 \\
\hline & & $3 \min$ & 704 & 86 \\
\hline & & $5 \mathrm{~min}$ & 1070 & 108 \\
\hline & & $5 \mathrm{~min}$ & 1348 & 140 \\
\hline & & $10 \mathrm{~min}$ & 715 & 97 \\
\hline
\end{tabular}




\section{EFFECT OF SURFACE PREPARATION}

The method used to condition surfaces of Zircaloy-2 for gas-pressure bonding is critical because the process involves only slight deformation. Extensive deformation during a bonding process such as roll cladding serves to disrupt contaminating surface layers and cause grain growth and recrystallization. Because of this significant effect of surface preparation on bond quality, a study was conducted to establish a method of surface conditioning that would consistently yield Zircaloy-to-Zircaloy bonds of high integrity.

Several series of specimens surface finished by various techniques were pressure bonded. Included in these series were specimens prepared with cold-rolled, grit-vapor blasted, belt-abraded, shot-peened, acid-pickled, barrel-finished, and machined surfaces. Each surface-preparation procedure was investigated in detail to assure that the optimum treatment was used. The objective of this investigation was to evaluate all of the bonds and select the lowest cost surface-conditioning treatment that would consistently produce a satisfactory bond. The bonds were evaluated metallographically to determine the amount of contamination and extent of grain growth across the original bond interface. They were also peel tested by driving a chisel into a V-notch at the bond interface, and, to determine their corrosion resistance, they were exposed to $750 \mathrm{~F}$ steam. Each sample consisted of two flat plates of Zircaloy-2 which had been identically surface conditioned. Pressure bonding was performed at $1550 \mathrm{~F}$ and 10,000 psi for 4 or $5 \mathrm{hr}$. The optimum bonding condition from the concurrent bonding-parameter study had not been determinedat the time these specimens were prepared; the condition chosen had previously been found to produce satisfactory bonding in somewhat similar specimens.

\section{Cold-Rolled Surfaces}

From a cost standpoint, the most desirable surface for bonding would be one which is cold rolled and cleaned without metal removal. Specimens prepared using cold-rolled stock fabricated from vapor blasted and washed hot-rolled stock were cleaned by a standard degreasing and washing treatment and pressure bonded. None of the bonds obtained with such surfaces were satisfactory. A typical bond is shown in Figure 4. The interface is contaminated and there is no grain growth across it. While such bonds are relatively strong and usually corrosion resistant, they are not considered acceptable because the interface is a possible plane of weakness.

\section{Pickled Surfaces}

The standard surface treatment of hot-rolled Zircaloy for other bonding operations usually includes grit-vapor blasting followed by acid pickling. In the present work two pickling solutions were used; one was the normal Zircaloy pickling solution consisting of 5 parts $\mathrm{HF}, 45$ parts $\mathrm{HNO}_{3}$, and 50 parts water, and the other was a 1 volume per cent solution of HF in concentrated nitric acid. Specimens prepared with these two pickling solutions exhibited about 5 per cent grain growth across the interface, and there appeared to be continuous contamination, as shown in Figure 5 .

To determine whether the pickled surfaces were contaminated prior to bonding, they were examined by electron diffraction. Tin, tin oxide, and zirconium oxide were found on the surfaces. During pickling of Zircaloy, tin presumably redeposits on the 


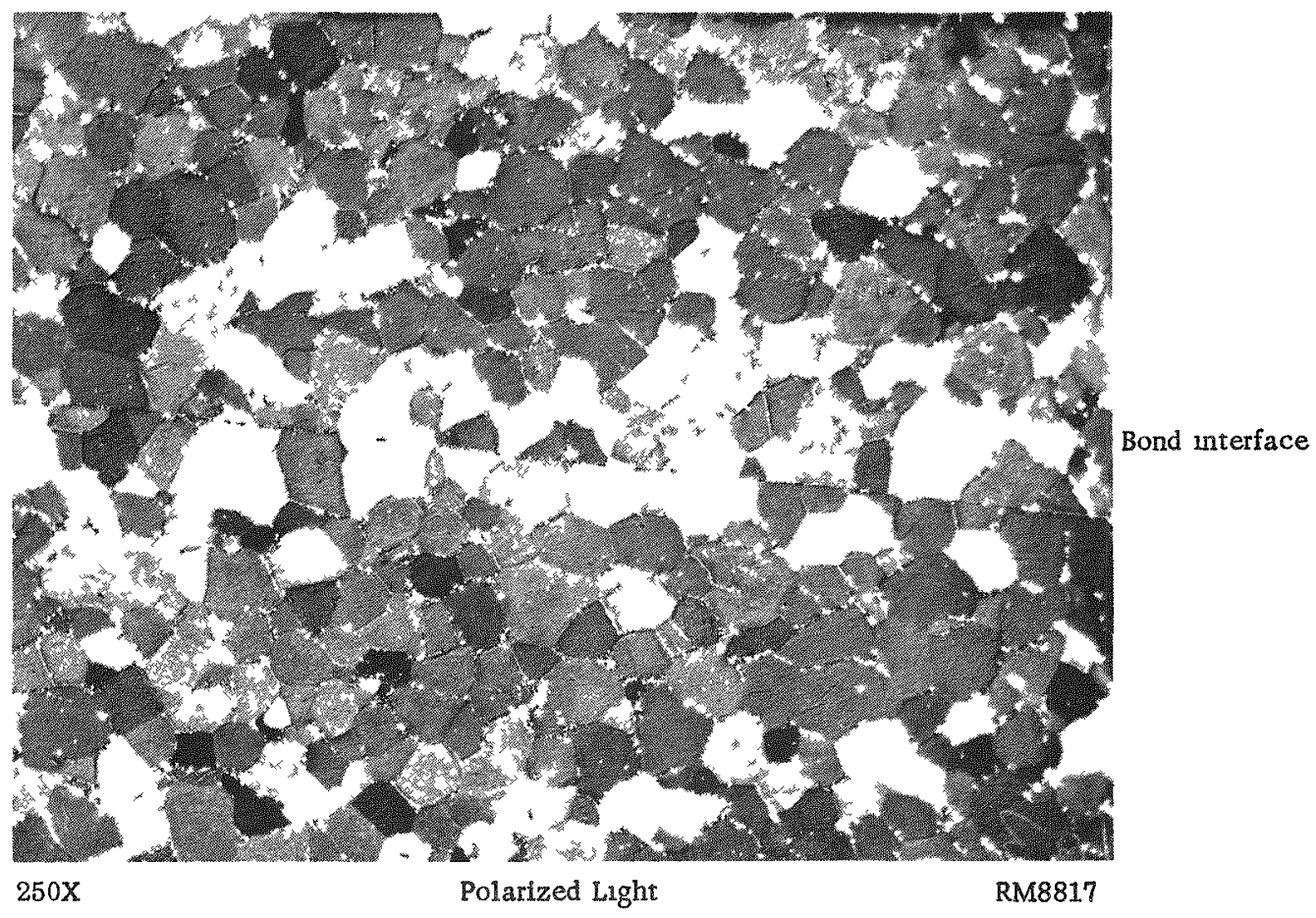

FIGURE 4. ZIRCALOY-TO-ZIRCALOY BOND OF SPECIMEN PREPARED BY GAS-PRESSURE BONDING AS-COLD-ROLLED ZIRCALOY

This specimen was bonded at $1550 \mathrm{~F}$ and 10,000 psi for $4 \mathrm{hr}$. Note the apparent presence of contamination and lack of grain growth.

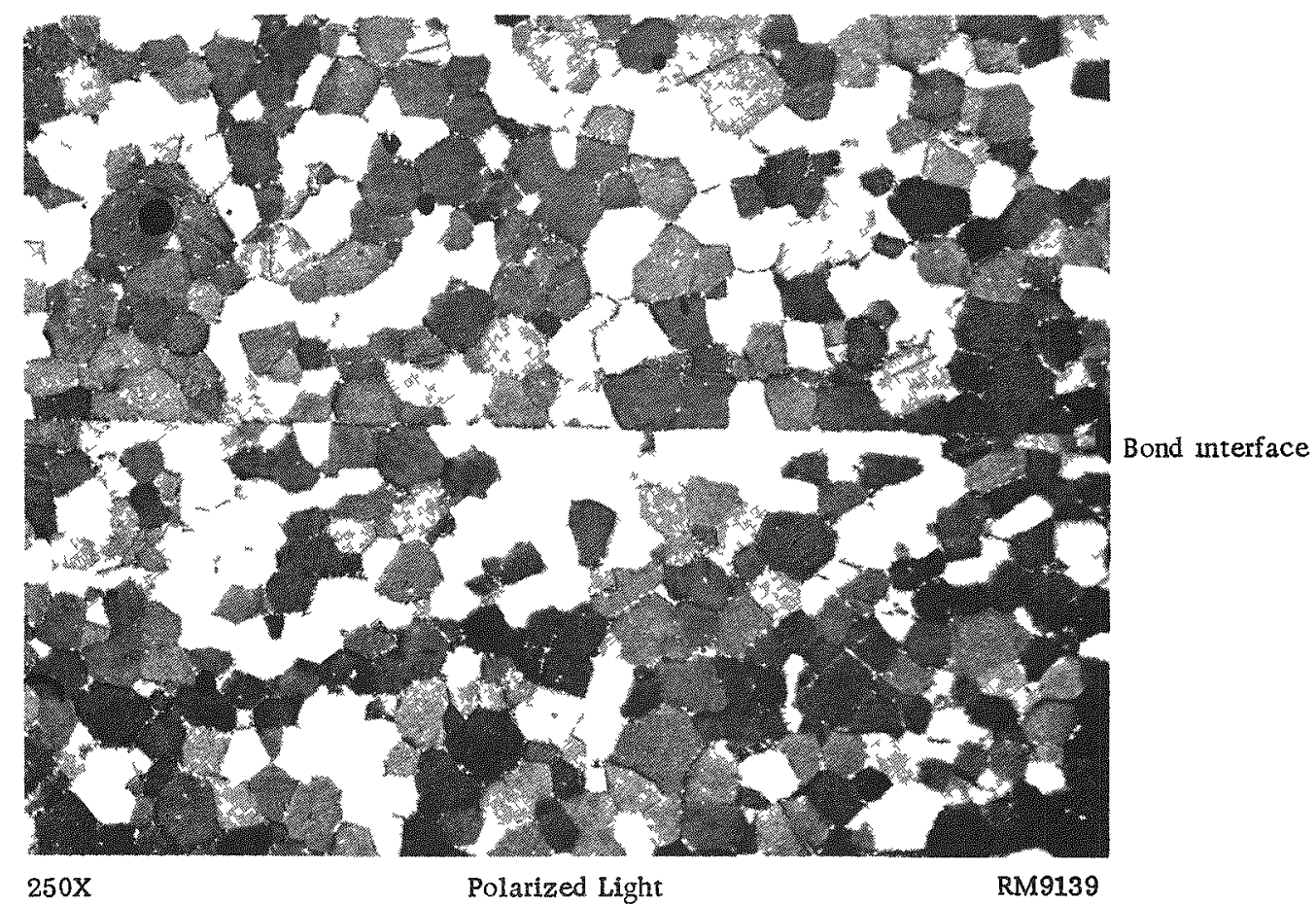

EIGURE 5. ZIRCALOY-TO-ZIRCALOY BOND OBTAINED BY PRESSURE BONDING ACID-PICKLED ZIRCALOY

This specimen was bonded at $1550 \mathrm{~F}$ and $10,000 \mathrm{psi}$ for $4 \mathrm{hr}$. Contunuous contamination and low grain growth are evident. 
surface by chemical replacement. In an effort to improve bonding of pickled surfaces, an attempt was made to remove surface contaminants by treating the material with $\mathrm{HCl}$, $\mathrm{HNO}_{3}, \mathrm{H}_{2} \mathrm{SO}_{4}$, or $\mathrm{NaOH}$ solutions following the $\mathrm{HF}$-solution pickle. No significant improvement in bonding was obtained with any of the se additional treatments. Also, electron-diffraction inspection of such surfaces still disclosed contamination by zirconium oxide, tin, or tin oxide. To attempt to activate the surface of the Zircaloy and thereby promote bonding, material which had previously been vapor blasted and pickled was cathodically charged with hydrogen in $\mathrm{H}_{2} \mathrm{SO}_{4}$ to form a thin surface layer of zir conium hydride. Results of pressure-bonded specimens prepared from this material showed no significant improvement in bonding. In general, the acid treatments were not considered to be promising. The results obtained with the various acid treatments are summarized in Table 5.

\section{Miscellaneous Surfaces}

A number of other surface-preparation methods were studied. These included vapor blasting, barrel finishing, and shot peening. None of these treatments was sufficiently promising to warrant extensive study. Table 6 contains a summary of the results obtained with these surface treatments.

\section{Machined and Belt-Abraded Surfaces}

The best bonds were obtained with surfaces prepared by machining or belt abrading. The machined specimens were finished on a shaper without a coolant. Excellent bonding was obtained with machined surfaces, as recorded in Table 7 , but good machining practice must be followed. Figure 6 shows a typical bond achieved between properly machined Zircaloy surfaces. Figure 7 illustrates the type of bond that is obtained when the speed of machining and amount of metal removal are excessive so that local overheating and surface oxidation occur. $X$-ray analyses of surfaces similar to that shown in Figure 7 revealed the presence of zirconium oxide on the surface. However, even this bond interface exhibited good strength and acceptable corrosion resistance. Use of a coolant during shaping is desirable to prevent overheating.

The best and most consistent bonds were obtained with surfaces prepared by belt abrading. Machine belt abrading is accomplished by passing the Zircaloy on a horizontal conveyer belt between a flat-feed bed and a fast-moving abrasive belt mounted in a vertical position. For best results, from 0.0005 to $0.001 \mathrm{in}$. of metal is removed per pass. The results of a study conducted to determine the optimum combination of abrasive-belt speed, type of coolant, type and size of abrasive grit, and amount of metal removal are tabulated in Table 8. Cold-rolled and hot-rolled material which was properly abraded to avoid any embedding of abrasive produced excellent bonds, as illustrated in Figures 8 and 9. The best surfaces for bonding were obtained using 60-grit silicon carbide belts operating at a speed of 2000 to $2700 \mathrm{ft}$ per min with a sulfonated-oil coolant.

Beta-Heat-Treated Specimens

Heat-treating studies at Bettis showed that a beta-phase heat treatment after pressure bonding promoted grain growth across the bond interface, because of the large driving force during transformation. All of the growth is apparently obtained during 
TABLE 5. EV ALUATION OF GAS -PRESSURE-BONDED SPECIMENS PREPARED WITH ACID-PICKLED ZIRCALOY SURF ACES

Specimens bonded at $1550 \mathrm{~F}$ and $10,000 \mathrm{psi}$ for $4 \mathrm{hr}$.

\begin{tabular}{|c|c|c|c|c|c|}
\hline Materıal & Surface Treatment & $\begin{array}{l}\text { Extent of } \\
\text { Contamination }\end{array}$ & $\begin{array}{l}\text { Amount of Grain } \\
\text { Growth Across } \\
\text { Interface, } \\
\text { per cent }\end{array}$ & $\begin{array}{l}\text { Results of } V \text {-Notch } \\
\text { Peel Test }\end{array}$ & $\begin{array}{l}\text { Result of Corrosion } \\
\text { Test ( } 1 \text { Week in } \\
750 \text { F Steam) }\end{array}$ \\
\hline \multirow[t]{3}{*}{$\begin{array}{l}\text { Cold rolled } \\
\qquad(3: 1)\end{array}$} & $100 \mathrm{~F}, 5 \mathrm{HF}-45 \mathrm{HNO}_{3}-50 \mathrm{H}_{2} \mathrm{O} ; 5 \mathrm{~min}$ in $120 \mathrm{~F} 20$ per cent $\mathrm{NaOH}$ & Light & 25 & Partial fallure & Slight attack \\
\hline & $100 \mathrm{~F}, 5 \mathrm{HF}-45 \mathrm{HNO}_{3}-50 \mathrm{H}_{2} \mathrm{O}$; wire brushed & Intermitrent & None & Fallure & Attack at all bonds \\
\hline & $\begin{array}{l}\text { Bollung, } 1 \mathrm{HF}-99 \mathrm{HNO}_{3}, 5 \text { min in } 120 \mathrm{~F} 20 \text { per cent } \mathrm{HCl} \text { and then } \\
20 \text { per cent } \mathrm{HNO}_{3}\end{array}$ & Light & None & Fanlure & Attack at all bonds \\
\hline \multirow[t]{4}{*}{ Hot rolled } & Bolling, $1 \mathrm{HF}-99 \mathrm{HNO}_{3}$ & Light & 5 & Good & Attack at all bonds \\
\hline & $\begin{array}{l}\text { Bolling, } 1 \mathrm{HF}-99 \mathrm{HNO}_{3} ; 5 \mathrm{~min} \text { in } 120 \mathrm{~F} 20 \text { per cent } \mathrm{HCl} \text { and then } \\
20 \text { per cent } \mathrm{HNO}_{3}\end{array}$ & Light & 5 & Good & Slight attack \\
\hline & $100 \mathrm{~F}, 5 \mathrm{HF}-45 \mathrm{HNO}_{3}-50 \mathrm{H}_{2} \mathrm{O}, 1 \mathrm{~min}$ in $100 \mathrm{~F} 50$ per cent $\mathrm{H}_{2} \mathrm{SO}_{4}$ & Light & 5 & Fanlure & Slight attack \\
\hline & $\begin{array}{l}100 \mathrm{~F}, 5 \mathrm{HF}-45 \mathrm{HNO}_{3}-50 \mathrm{H}_{2} \mathrm{O} \text {, cathod cally charged in } \mathrm{H}_{2} \mathrm{SO}_{4} \text { to } \\
\text { form } \mathrm{ZrH}_{2} \text { surface layer }\end{array}$ & Light & 10 & Good & Slight attack \\
\hline
\end{tabular}


TABLE 6. EVALUATION OF PRESSURE-BONDED ZIRCALOY SPECIMENS WITH MISCELLANEOUS SURFACE TREATMENTS

Specimens bonded at $1550 \mathrm{~F}$ and 10,000 psi for $5 \mathrm{hr}$.

\begin{tabular}{|c|c|c|c|c|c|}
\hline Material & Surface Treatment & $\begin{array}{l}\text { Extent of } \\
\text { Contamination }\end{array}$ & $\begin{array}{l}\text { Amount of Grain } \\
\text { Growth Across } \\
\text { Interface, } \\
\text { per cent }\end{array}$ & $\begin{array}{l}\text { Results of V-Notch } \\
\text { Peel Test }\end{array}$ & $\begin{array}{l}\text { Results of Corrosion Test } \\
\text { ( } 1 \text { Week in } 750 \mathrm{~F} \text { Stearn) }\end{array}$ \\
\hline $\begin{array}{l}\text { Cold rolled } \\
(2: 1)\end{array}$ & Barrel finished, alumina abrasive & Heavy & 5 & Good & Heavy attack \\
\hline \multirow[t]{7}{*}{$\begin{array}{l}\text { Cold rolled } \\
(3: 1)\end{array}$} & $\begin{array}{l}\text { Barrel finished, alumina abrasive; } 2 \mathrm{hr} \text { in } 20 \text { per } \\
\text { cent boiling } \mathrm{NaOH}\end{array}$ & Heavy & 5 & Good & Heavy attack \\
\hline & $\begin{array}{l}\text { Vapor blasted, } 100-\text { and } 400 \text {-mesh alumina; } 5 \text { min each in } 20 \text { per cent } \\
\mathrm{NaOH} \text { and } 20 \text { per cent } \mathrm{HCl}\end{array}$ & Heavy & None & Good & Heavy attack \\
\hline & Vapor blasted, $100-$ and $400-$ mesh alumina & Heavy & None & Failed & Heavy attack \\
\hline & Vapor blasted, $400-$ mesh alumina; $2-1 / 2 \mathrm{hr}$ in boiling 20 per cent $\mathrm{NaOH}$ & Heavy & None & Good & Heavy attack \\
\hline & Vapor blasted, 325-mesh zirconia & Heavy & 5 & Failed & Heavy atrack \\
\hline & Shot peened, 0.040 to 0.060 -in. hardened steel shot & Heavy & 15 & Good & Heavy attack \\
\hline & $\begin{array}{l}\text { Shot peened, } 0.040 \text { to } 0.060 \text {-in. hardened steel shot; } 15 \text { min in } 20 \text { per } \\
\text { cent } \mathrm{HCl}\end{array}$ & Heavy & 10 & Partial failure & Heavy attack \\
\hline Hot rolled & $\begin{array}{l}\text { Shot peened, } 0.040 \text { to } 0.060 \text {-in. hardened steel shot; } 2 \mathrm{hr} \text { in } 20 \text { per cent } \\
\mathrm{HCl}\end{array}$ & Heavy & 20 & Good & Light attack at all bonds \\
\hline
\end{tabular}


TABLE 7. EVALUATION OF PRESSURE -BONDED SPECIMENS PREPARED WITH MACHINED ZIRCALOY SURFACES

Specimens bonded at $1550 \mathrm{~F}$ and 10,000 psi for $4 \mathrm{hr}$.

\begin{tabular}{|c|c|c|c|c|c|}
\hline \multirow{2}{*}{$\begin{array}{l}\text { Cold rolled } \\
(3: 1)\end{array}$} & 0.003 & 95 & None & Good & No attack \\
\hline & 0.003 & 80 & Light & Good & No attack \\
\hline \multirow[t]{2}{*}{ Hot rolled } & 0.060 & 95 & None & Good & No attack \\
\hline & 0.060 & 85 & Light & Good & No attack \\
\hline
\end{tabular}




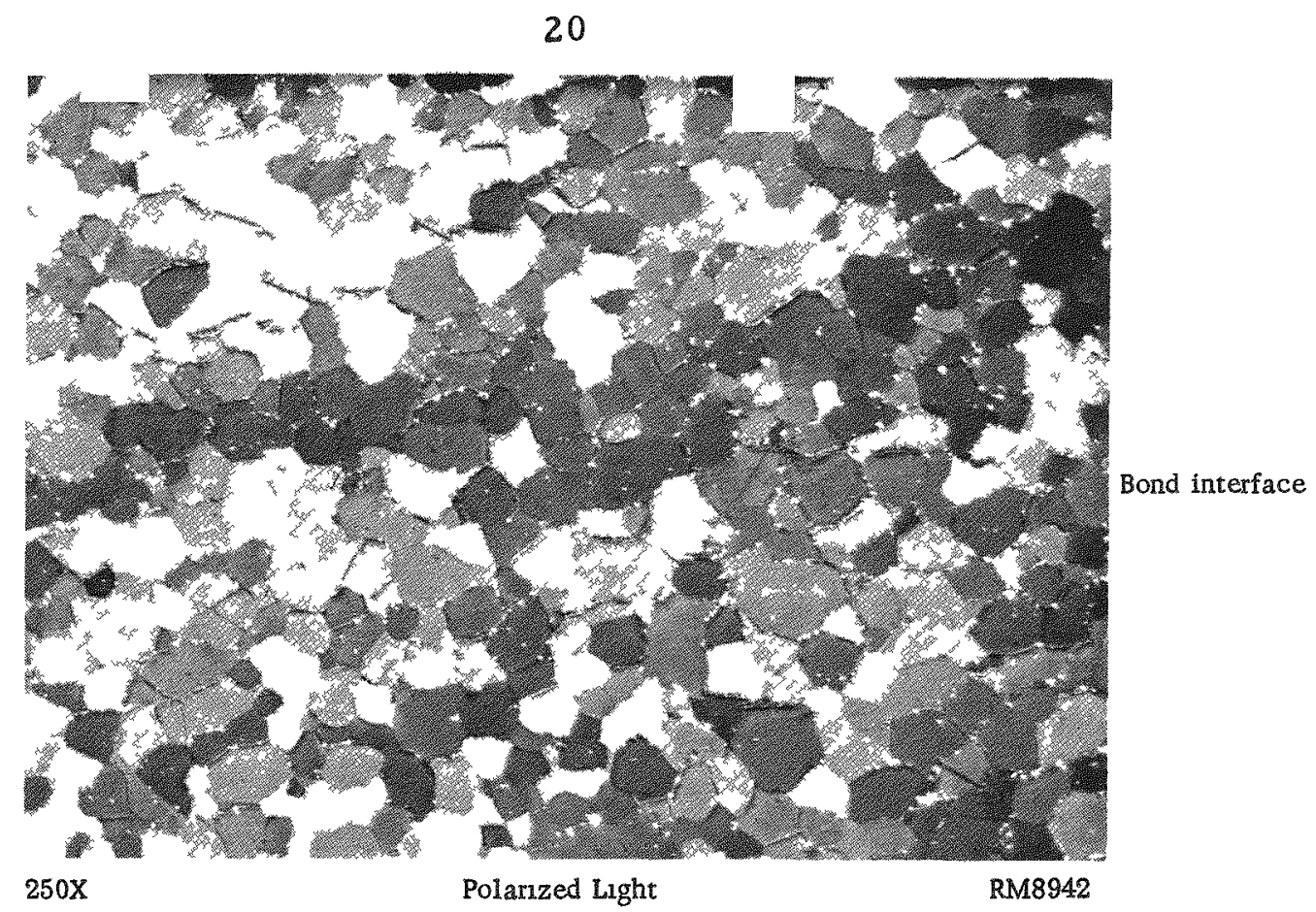

FIGURE 6. ZIRCALOY-TO-ZIRCALOY BOND ACHIEVED BY PRESSURE BONDING PROPERLY MACHINED ZIRCALOY Specimen was bonded at $1550 \mathrm{~F}$ and $10,000 \mathrm{psi}$ for $4 \mathrm{hr}$

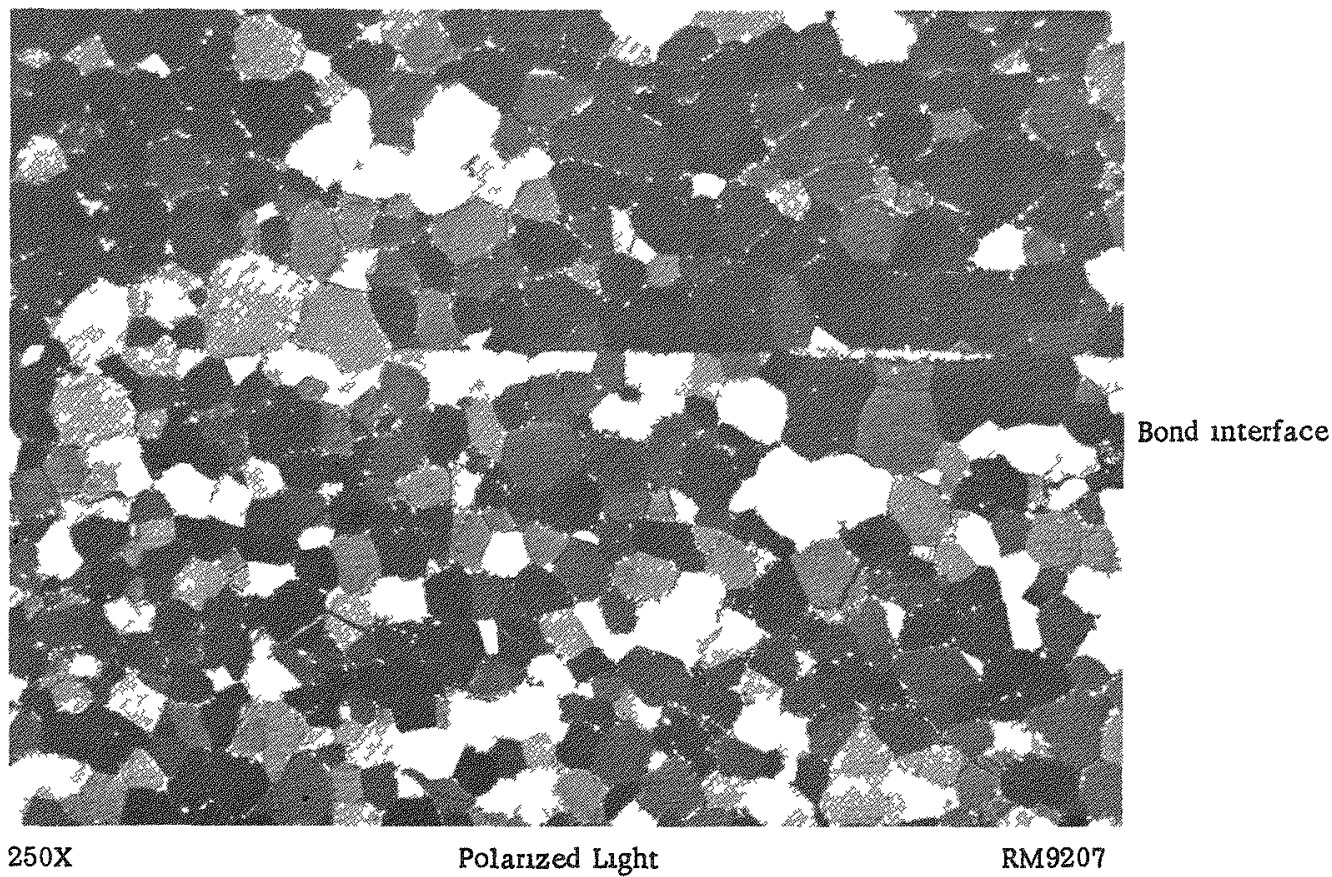

FIGURE 7. ZIRCALOY-TO-ZIRCALOY BOND ACHIEVED BY PRESSURE BONDING IMPROPERLY MACHINED ZIRCALOY

Excessive rate of metal removal dunng machunng caused local overheatung and oxidation of this specumen bonded at $1550 \mathrm{~F}$ and $10,000 \mathrm{psi}$ for $4 \mathrm{hr}$. Note the inclusion at the onginal bond interface. Further metallographic preparation involving the removal of 1 mil of additional metal completely removed this inclusion. 
TABLE 8. EVALUATION OF PRESSURE-BONDED SPECIMENS PREPARED WITH MACHINE BELT-ABRADED ZIRCALOY SURFACES

Specimens bonded at $1550 \mathrm{~F}$ and 10,000 psi for $5 \mathrm{hr}$.

\begin{tabular}{|c|c|c|c|c|c|c|c|c|c|}
\hline \multirow[b]{2}{*}{ Material } & \multicolumn{5}{|c|}{ Belt-Abrading Conditions } & \multirow{2}{*}{$\begin{array}{l}\text { Amount of } \\
\text { Grain } \\
\text { Growth, } \\
\text { per cent }\end{array}$} & \multirow[b]{2}{*}{$\begin{array}{c}\text { Extent of } \\
\text { Contamination }\end{array}$} & \multirow{2}{*}{$\begin{array}{l}\text { Results of } \\
V \text {-Notch } \\
\text { Peel Test }\end{array}$} & \multirow{2}{*}{$\begin{array}{l}\text { Results of } \\
\text { Corrosion Test } \\
\text { ( } 1 \text { Week in } \\
750 \text { F Steam) }\end{array}$} \\
\hline & $\begin{array}{l}\text { Metal Removal, } \\
\text { in. per side }\end{array}$ & Abrasive & Grit & $\begin{array}{l}\text { Belt Speed, } \\
\text { ft per min }\end{array}$ & Coolant & & & & \\
\hline \multirow[t]{8}{*}{ Hot rolled } & 0.003 & $\mathrm{SiC}$ & 60 & 5500 & Water & 85 & Light & Good & No attack \\
\hline & 0.002 & $\mathrm{SiC}$ & 60 & 5500 & Water & 95 & Very little & Good & No attack \\
\hline & 0.003 & $\mathrm{SiC}$ & 180 & 5500 & Water & 85 & Light & Good & No attack \\
\hline & 0.005 & $\mathrm{SiC}$ & 60 & 2700 & $\begin{array}{l}\text { Sulfonated } \\
\text { oil }\end{array}$ & 100 & None & Good & No attack \\
\hline & 0.001 & $\mathrm{SiC}$ & 60 & 1100 & $\begin{array}{l}\text { Sulfonated } \\
\text { oil }\end{array}$ & 90 & None & Good & No attack \\
\hline & 0.003 & $\mathrm{SiC}$ & 60 & 1100 & $\begin{array}{l}\text { Sulfonated } \\
\text { oil }\end{array}$ & 90 & None & Good & No attack \\
\hline & 0.005 & $\mathrm{SiC}$ & 60 & 2700 & $\begin{array}{l}\text { Sulfonated } \\
\text { oil }\end{array}$ & 100 & None & Good & No attack \\
\hline & 0.003 & $\mathrm{Al}_{2} \mathrm{O}_{3}$ & 60 & 5500 & Water & 20 & None & Good & Slight attack \\
\hline \multirow[t]{5}{*}{ Cold rolled } & 0.001 & $\mathrm{SiC}$ & 180 & 5500 & Water & 35 & Intermittent & Good & No attack \\
\hline & 0.002 & $\mathrm{SiC}$ & 180 & 5500 & Water & 30 & Intermittent & Good & No attack \\
\hline & 0.003 & $\mathrm{SiC}$ & 60 & 2000 & $\begin{array}{l}\text { Sulfonared } \\
\text { oil }\end{array}$ & 95 & None & Good & No attack \\
\hline & 0.003 & $\mathrm{SiC}$ & 60 & 2000 & $\begin{array}{l}\text { Sulfonated } \\
\text { oil }\end{array}$ & 95 & None & Good & No attack \\
\hline & 0.005 & $\mathrm{SiC}$ & 60 & 2000 & $\begin{array}{l}\text { Sulfonated } \\
\text { oil }\end{array}$ & 95 & None & Good & No attack \\
\hline
\end{tabular}




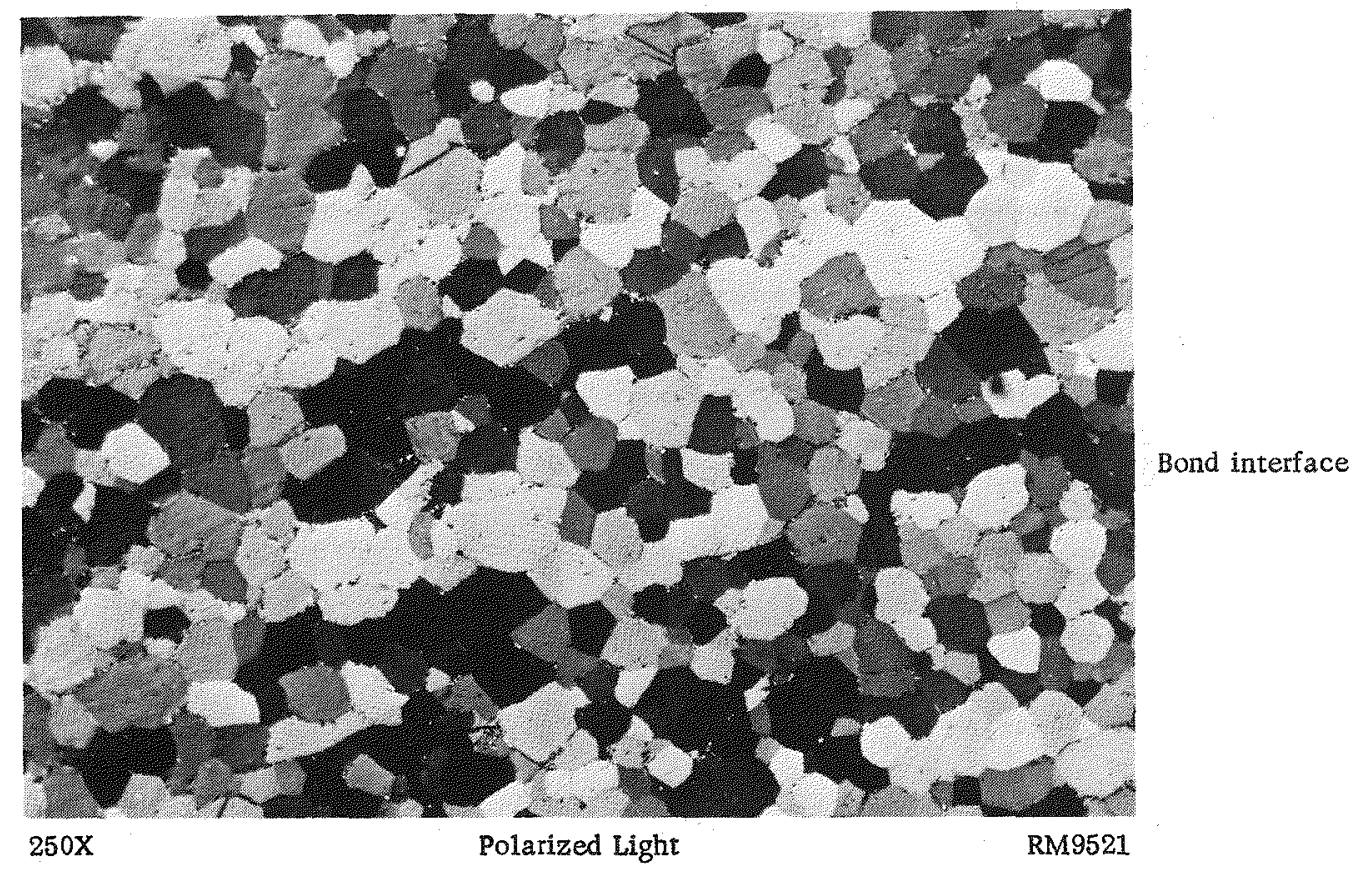

FIGURE 8. BOND ACHIEVED WITH COLD-ROLLED AND BELT-ABRADED ZIRCALOY

The specimen was pressure bonded at $1550 \mathrm{~F}$ and 10,000 psi for $5 \mathrm{hr}$.

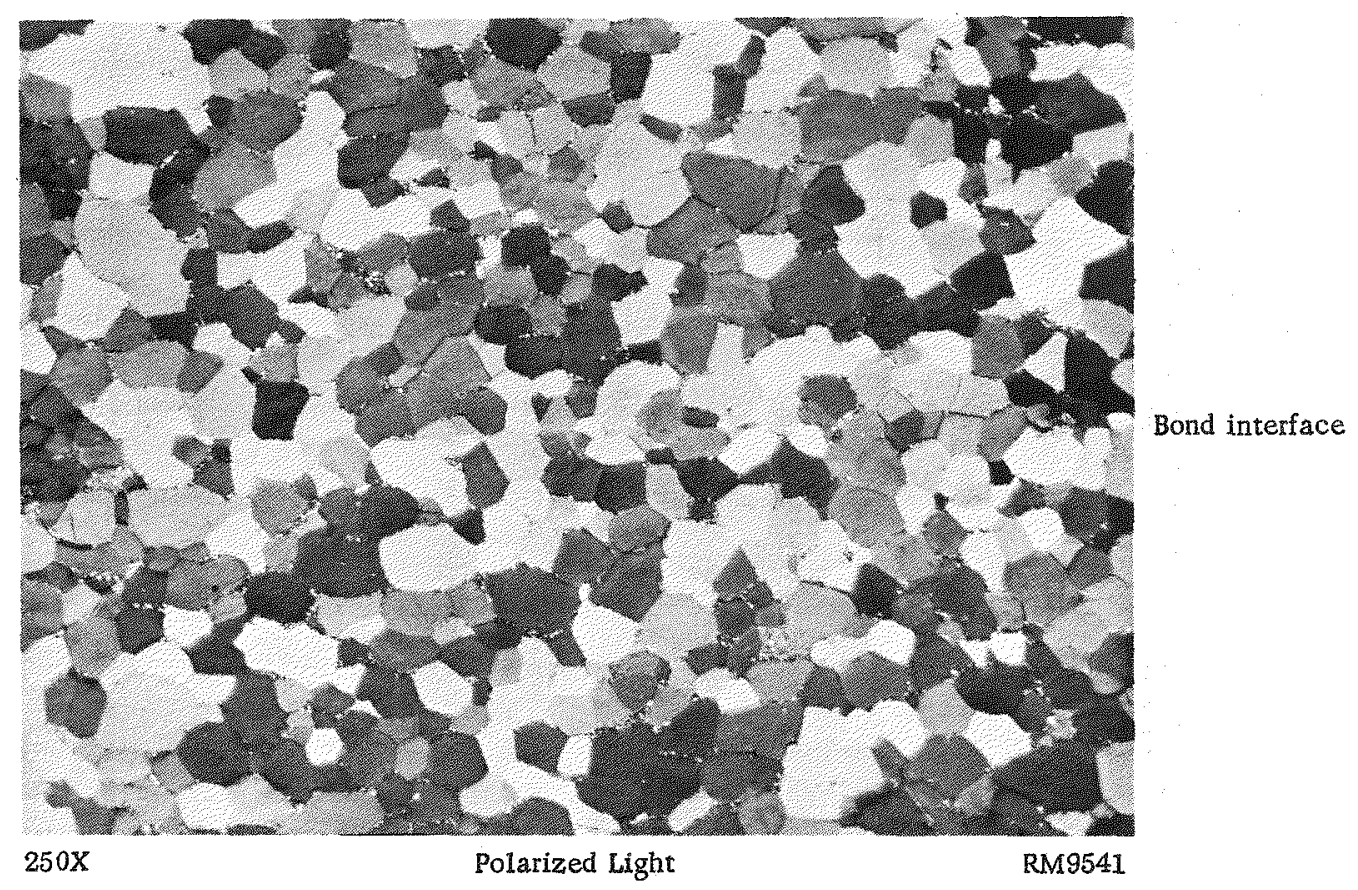

FIGURE 9. BOND PREPARED FROM HOT-ROLLED AND BELT-ABRADED ZIRCALOY

This specimen was pressure bonded at $1550 \mathrm{~F}$ and 10,000 psi for $5 \mathrm{hr}$. 
transformation and a short time thereafter, so that a short salt-bath treatment is sufficient. A number of the surface-prepared specimens were given a 5 to 15 -min heat treatment at $1850 \mathrm{~F}$ after pressure bonding to determine the extent of bond improvement. The treatment was found to be especially effective in specimens lacking grain. growth but possessing only light bond-line contamination. Figure 10 illustrates a specimen bonded with a properly abraded surface and Figure 11 shows the same bond interface after a beta heat treatment. Similar conditions are shown in Figures 12 and 13 for a machined specimen. This specimen possesses an irregular, but readily detectable, bond interface after pressure bonding which is significantly improved by a beta heat treatment. Figures 14 and 15 show a specimen bonded with as-rolled Zircaloy. In this specimen, appreciable grain growth across the interface was obtained by the beta heat treatment; however, the contamination at the original interface is clearly visible after the heat treatment.

As a result of these studies, machine belt abrading was chosen as the reference method of surface preparation. This process is relatively inexpensive, being of comparable cost to an acid-pickling treatment. A short-time beta heat treatment after pressure bonding consisting of a 5 -min immersion in a barium chloride salt bath at $1850 \mathrm{~F}$ was also found desirable for added assurance of bond integrity.

\section{CORE-CLADDING-REACTION ST UDIES}

Previous investigations have revealed that uranium dioxide is reduced by zirconium(4). The reaction products are alpha uranium and alpha zirconium rich in oxygen, plus small amounts of the zirconium-uranium epsilon phase. Very slight reaction has been observed as low as $950 \mathrm{~F}$, but reaction does not become significant until the temperature is above $1100 \mathrm{~F}$. Although it was known that appreciable reaction would be obtained at the pressure-bonding temperatures of 1450 to $1550 \mathrm{~F}$, the effects of this reaction on the properties of the fuel element, especially on the corrosion resistance of the interface, were not known. Also, suitable barrier layers which could be used to prevent this reaction had not been determined.

Zircaloy-clad specimens with bare $\mathrm{UO}_{2}$ cores and with various barrier layers were pressure bonded at temperatures of 1450 to $1550 \mathrm{~F}$. Evaluations of the specimens were based on metallographic examinations and corrosion tests in $680 \mathrm{~F}$ water and $750 \mathrm{~F}$ steam. The corrosion specimens were either sectioned or were defected by drilling a 0,040-in.-diameter hole through the cladding. Additional pressure-bonded specimens were beta heat treated and then examined and tested. Square cores composed of $\mathrm{Al}_{2} \mathrm{O}_{3}-21 \mathrm{w} / \mathrm{O} \mathrm{UO}_{2}$ and 100 per cent $\mathrm{UO}_{2}$ were utilized initially in the core-claddingreaction investigation. Later, because the fuel design specifications were altered, rectangular cores of 100 per cent $\mathrm{UO}_{2}$ were used.

\section{Specimens With Bare Cores}

Specimens with bare fuel cores were pressure bonded and, in some cases, heat treated to determine the effect of the core-cladding reaction and the necessity for a barrier layer between the $\mathrm{UO}_{2}$ and the Zircaloy. Figure 16 illustrates the reaction 


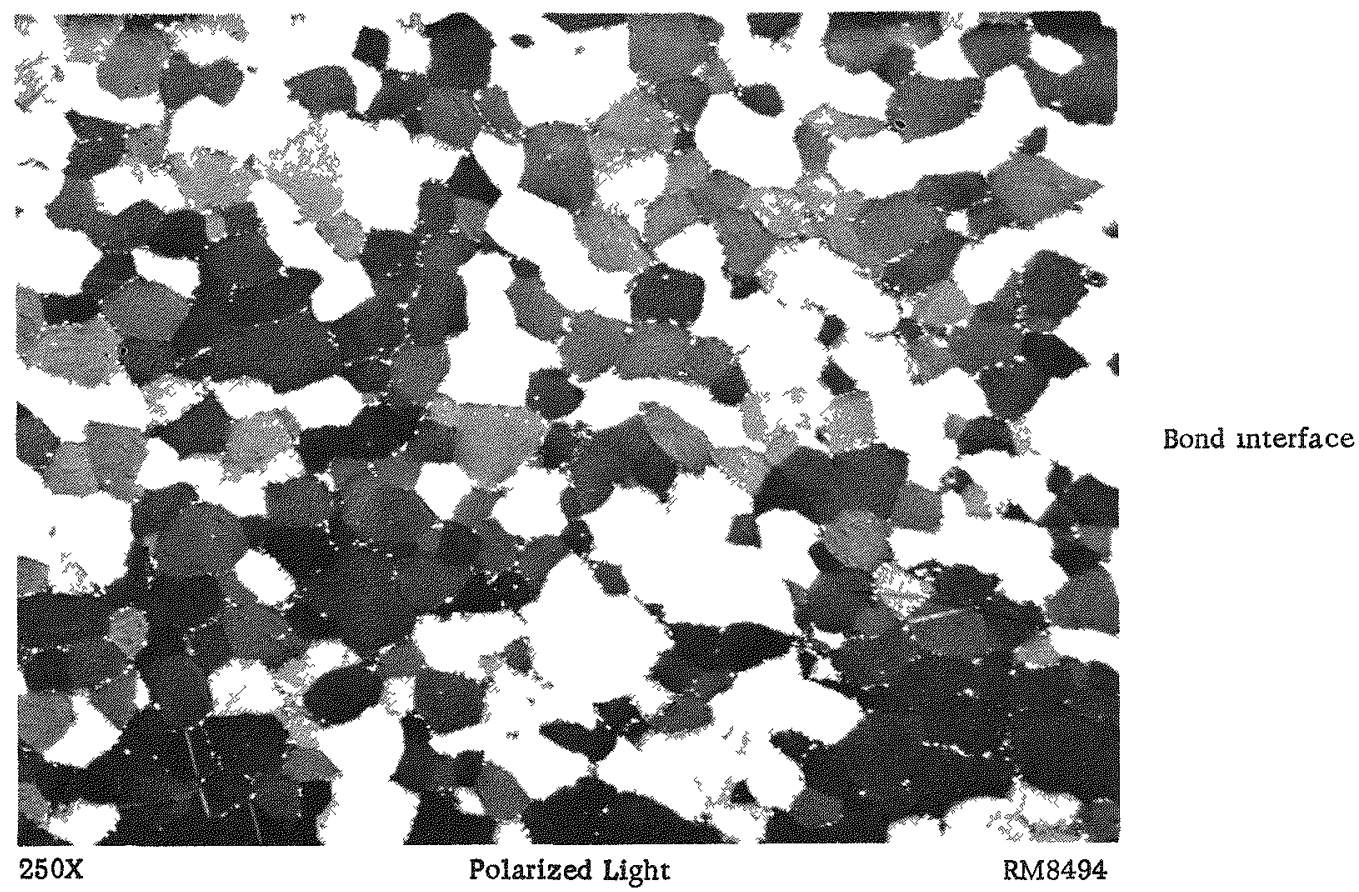

FIGURE 10. ZIRCALOY-TO-ZIRCALOY BOND OBTAINED WITH BELT-ABRADED MATERIAL

The specimen was bonded at $1550 \mathrm{~F}$ and $10,000 \mathrm{psi}$ for $4 \mathrm{hr}$.

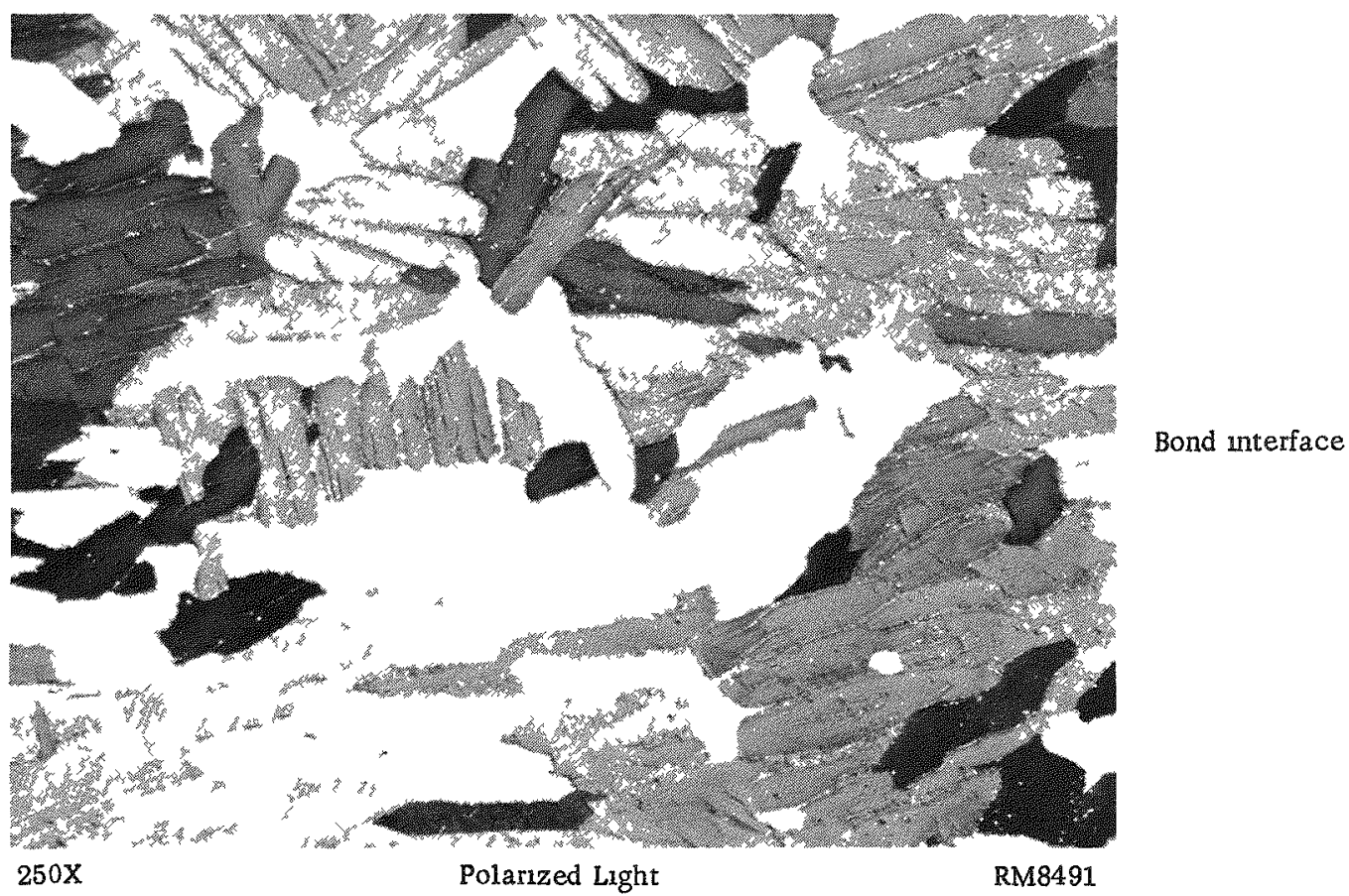

FIGURE 11 SAME SPECIMEN SHOWN IN FIGURE 10 AFTER AN ADDITIONAL HEAT TREATMENT OF 15 MIN AT 1850 F 


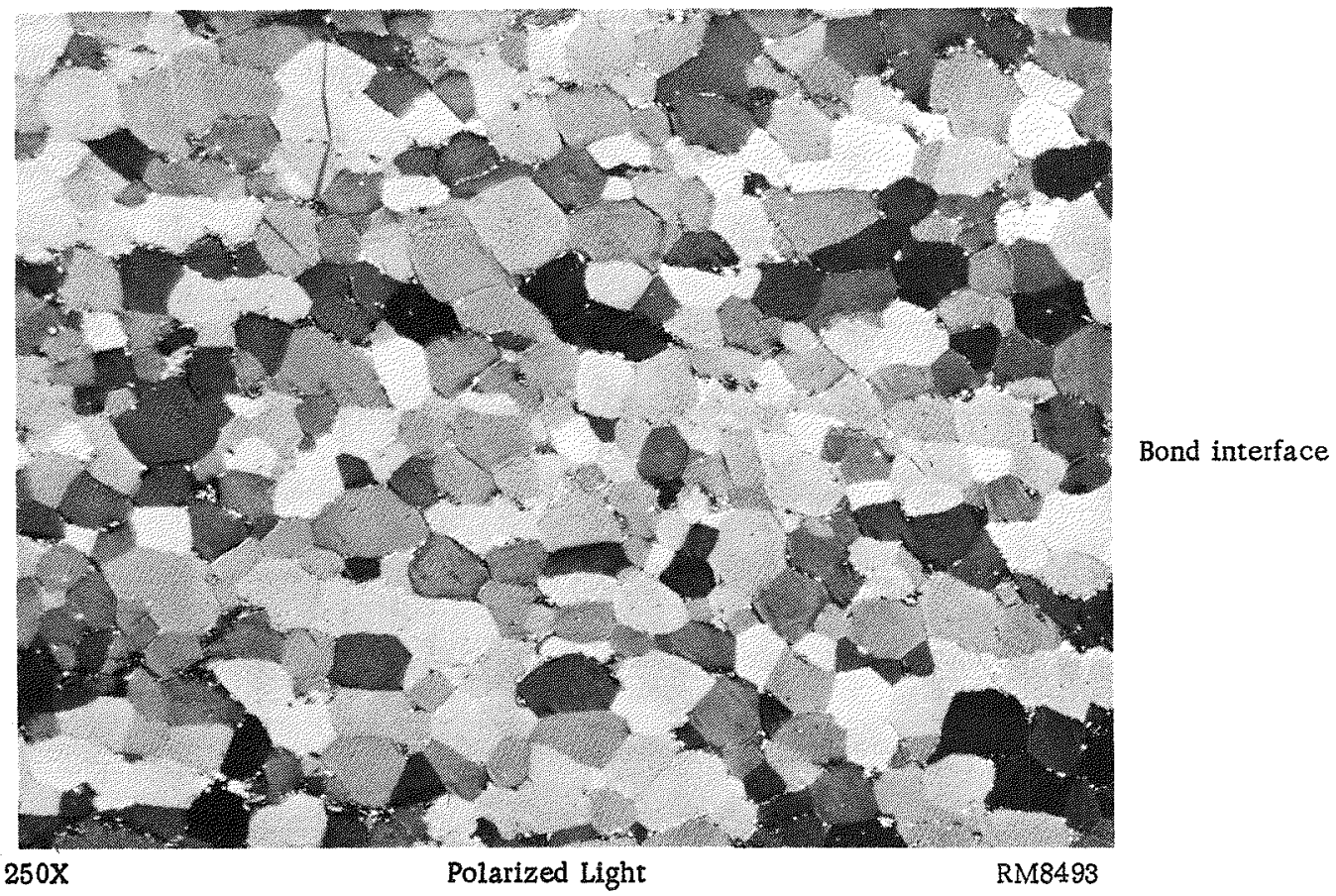

FIGURE 12. ZIRCALOY-TO-ZIRCALOY BOND PREPARED WITH HOT-ROLLED AND MACHINED MATERIAL

This specimen was bonded at $1550 \mathrm{~F}$ and $10,000 \mathrm{psi}$ for $4 \mathrm{hr}$. Note lack of complete grain growth across bond interface resulting from improper machining.

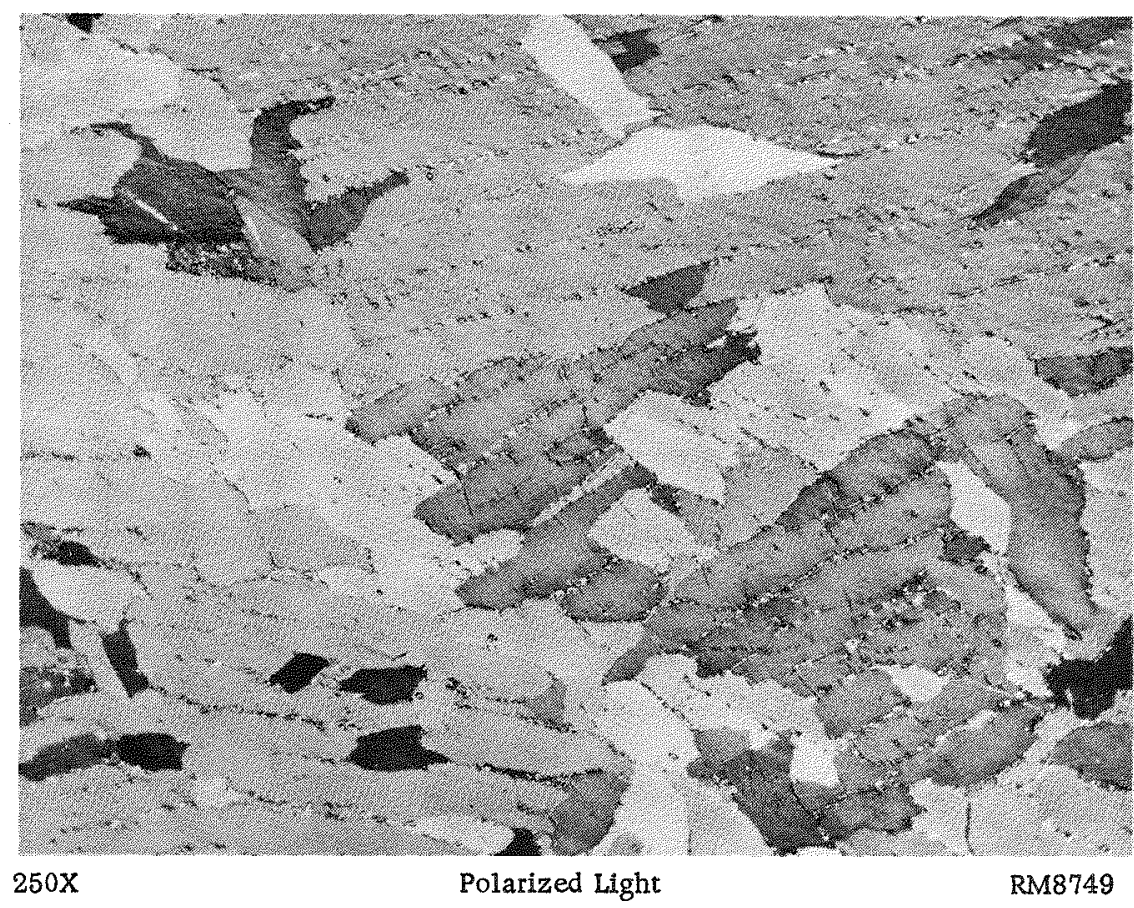

Bond interface

FIGURE 13. SAME SPECIMEN SHOWN IN FIGURE 12 AFTER AN ADDITIONAL HEAT TREATMENT OF 15 MIN AT $1850 \mathrm{~F}$ 


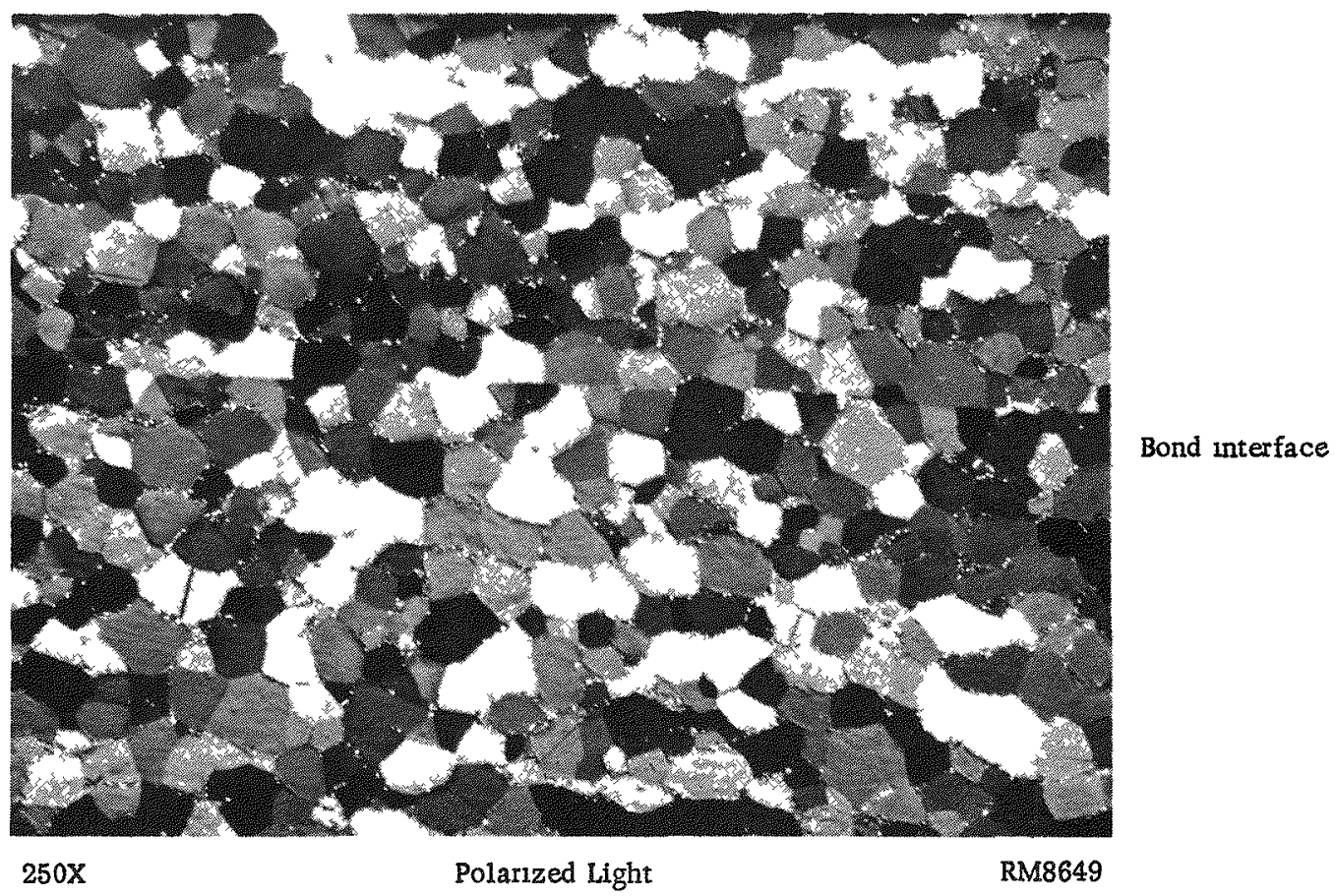

FIGURE 14, ZIRCALOY-TO-ZIRCALOY BOND ACHIEVED WITH AS-ROLLED MATERIAL

This specimen was bonded at $1550 \mathrm{~F}$ and 10,000 psi for $4 \mathrm{hr}$. Note lack of grain growth.

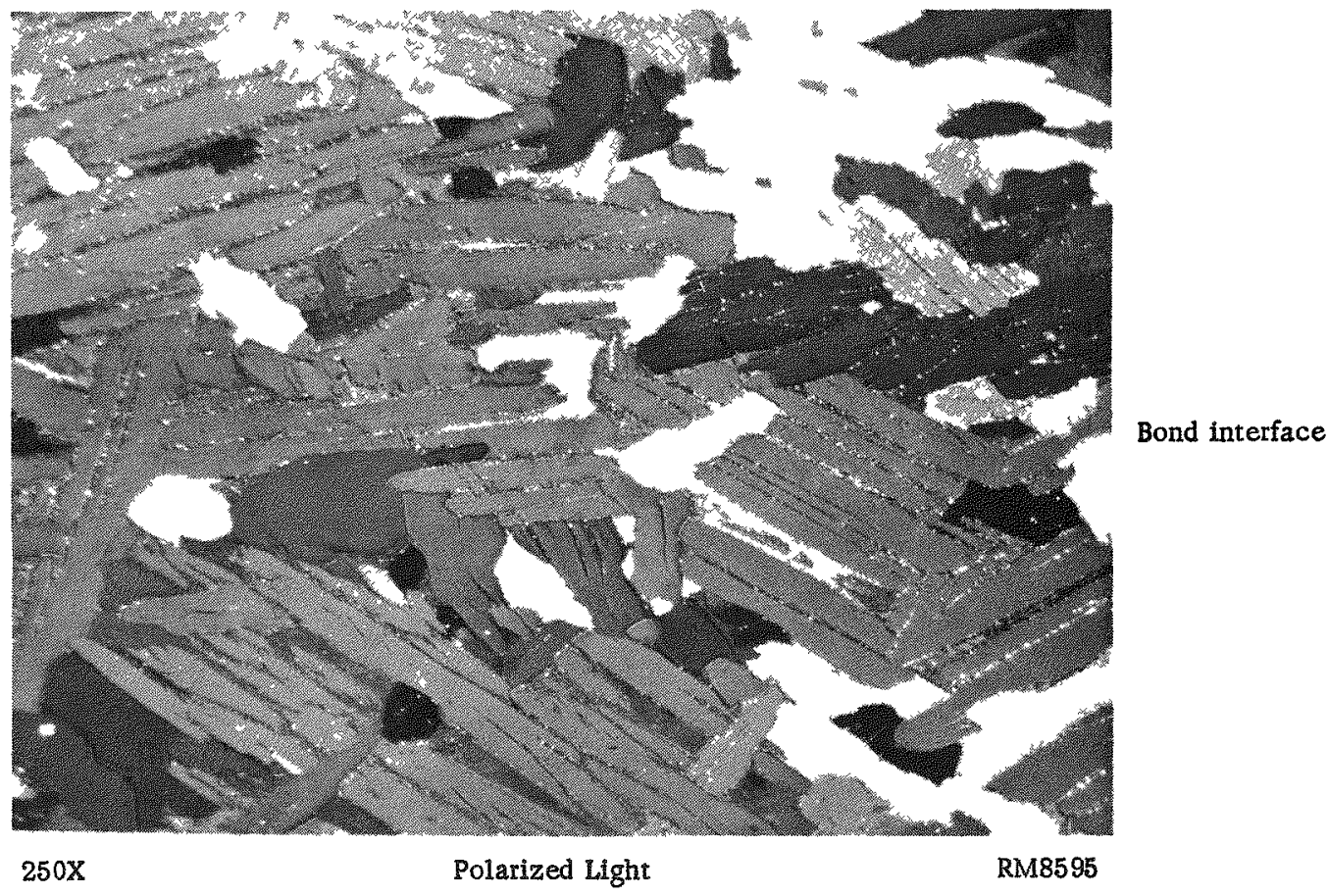

FIGURE 15. SAME SPECIMEN SHOWN IN FIGURE I4 AFTER AN ADDITIONAL BET A TREATMENT OF 15 MIN AT 1850 E

Note grain growth across light contamination in most areas of the bond interface. 
between a 100 per cent $\mathrm{UO}_{2}$ core and the Zircaloy cladding obtained during pressure bonding at $1550 \mathrm{~F}$ for $5 \mathrm{hr}$. The effect of a beta-phase heat treatment at $1850 \mathrm{~F}$ for 5 min on a duplicate pressure-bonded specimen containing a 100 per cent $\mathrm{UO}_{2}$ core is illustrated in Figure 17. It is apparent that there was considerable reaction after pressure bonding and that there was a slight increase in the reaction during the short beta heat treatment.

The results of the corrosion tests are summarized in Table 9. Extensive attack was observed at the bare core-to-Zircaloy interface in all of the specimens in both $680 \mathrm{~F}$ water and $750 \mathrm{~F}$ steam. In the specimens defected with a $0.040-$ in. hole, a growth in thickness of from 0.008 to $0.035 \mathrm{in}$. was observed in approximately 10 weeks. Metallographic examination revealed that the reaction zone was severely attacked.

From the metallographic examinations and corrosion testing, it became apparent that a barrier layer would be required, and a survey of possible barrier materials was made.

\section{Specimens Containing Barrier Layers}

A series of specimens was pressure bonded which contained cores that had been coated with various barrier materials, including graphite, chromium, iron, molybdenum, nickel, niobium, palladium, and several oxides. Techniques for obtaining a satisfactory coating on the cores had to be developed for most of the barrier materials. In some instances pressure bonding was followed by a heat treatment at $1850 \mathrm{~F}$.

\section{Graphite Barrier}

During this phase of the program the graphite was applied by brushing Neolube, a suspension of graphite in alcohol, onto the surfaces of the cores. To remove volatile hydrocarbons, the Neolube coating was baked in vacuum at $750 \mathrm{~F}$. After drying, the cores were handled carefully during the assembly operation. Graphite in the Zircaloy-Zircaloy bond interface must be avoided if good bonds are to be obtained.

Specimens containing graphite-coated cores were pressure bonded at 1450 to $1550 \mathrm{~F}$, and some were additionally beta heat treated. The results recorded in Table 10 show that only a small thickness increase or no increase was obtained for pressurebonded specimens which were defected with 0.040 . -diameter holes and tested in $680 \mathrm{~F}$ water and $750 \mathrm{~F}$ steam. Metallographic examination revealed a minimum amount of uranium-zirconium reaction between the fuel and the cladding during pressure bonding as shown in Figure 18. Examination of beta-heat-treated specimens revealed that graphite also was excellent barrier material during a short-time heat treatment at $1850 \mathrm{~F}$ (Figure 19). Beta-treated and defected specimens containing graphite-coated cores showed no growth during corrosion testing in $680 \mathrm{~F}$ water. As the procedure for graphite-coating of the cores was improved, less growth of the fuel compartments occurred during corrosion; this can be noted in Table 10, which lists the specimens in the order in which they were prepared.

It should be noted here that during the final evaluation studies of a large number of specimens bonded in containers with Neolube-coated cores, it became apparent based on metallographic examination that the Neolube was not completely effective in preventing 
TABLE 9. CORROSION RESULTS FOR DEFECTED SPECIMENS WITHOUT A BARRIER LAYER BETWEEN THE CORE AND ZIRCALOY CLADDING

\begin{tabular}{|c|c|c|c|c|c|c|c|c|c|}
\hline \multirow[b]{2}{*}{$\begin{array}{c}\text { Fuel-Core } \\
\text { Composition, w/o }\end{array}$} & \multirow[b]{2}{*}{ Specimen } & \multicolumn{3}{|c|}{ Bonding Conditions } & \multicolumn{2}{|c|}{ Heat Treatment } & \multirow[b]{2}{*}{$\begin{array}{l}\text { Duration of } \\
\text { Test, weeks }\end{array}$} & \multirow[b]{2}{*}{$\begin{array}{l}\text { Corrosion } \\
\text { Condition }\end{array}$} & \multirow{2}{*}{$\begin{array}{c}\text { Total } \\
\text { Growth. } \\
\text { in. }\end{array}$} \\
\hline & & $\begin{array}{c}\text { Temperature, } \\
F\end{array}$ & Time, & $\begin{array}{l}\text { Pressure, }_{3} \\
\text { psi }\end{array}$ & $\begin{array}{c}\text { Temperature, } \\
\text { F }\end{array}$ & $\begin{array}{c}\text { Time, } \\
\text { min }\end{array}$ & & & \\
\hline \multirow{13}{*}{$\mathrm{Al}_{2} \mathrm{O}_{3}-21 \mathrm{UO}_{2}$} & $H-101=C$ & 1550 & 5 & 10,000 & None & None & 16 & $750 \mathrm{~F}$ steam & 0.016 \\
\hline & $\mathrm{H}-114-\mathrm{C}$ & 1550 & 4 & 10,000 & None & None & 15 & $750 \mathrm{~F}$ steam & 0.029 \\
\hline & $H-114-D^{(a)}$ & 1550 & 4 & 10,000 & None & None & 3 & 750 F steam & 0.018 \\
\hline & H $119-\mathrm{C}$ & 1550 & 4 & 10,000 & None & None & 12 & $750 \mathrm{~F}$ steam & 0.017 \\
\hline & $H-119-D^{(a)}$ & 1550 & 4 & 10,000 & None & None & 12 & $750 \mathrm{~F}$ steam & 0.026 \\
\hline & $C-105$ & 1550 & 5 & 10,000 & None & None & 16 & 750 F steam & 0.012 \\
\hline & $H-119-W$ & 1550 & 4 & 10,000 & None & None & 11 & $680 \mathrm{~F}$ water & 0.008 \\
\hline & $\mathrm{H}-122-\mathrm{A}$ & 1550 & 5 & 10,000 & 1650 & 240 & 10 & $680 \mathrm{~F}$ water & 0.029 \\
\hline & $H-122-B$ & 1550 & 5 & 10,000 & 1650 & 240 & 10 & $680 \mathrm{~F}$ water & 0.029 \\
\hline & $\mathrm{H}-123-1 \mathrm{~A}$ & 1550 & 5 & 10,000 & None & None & 11 & $680 \mathrm{~F}$ water & 0.011 \\
\hline & $H-123-1 B$ & 1550 & 5 & 10,000 & None & None & 11 & $680 \mathrm{~F}$ water & 0.010 \\
\hline & $\mathrm{H}-123-2 \mathrm{~A}$ & 1550 & 5 & 10,000 & 1850 & 15 & 10 & $680 \mathrm{~F}$ water & 0.028 \\
\hline & $\mathrm{H}-123-2 \mathrm{~B}$ & 1550 & 5 & 10,000 & 1850 & 15 & 10 & 680 F water & 0.028 \\
\hline \multirow{8}{*}{$\mathrm{UO}_{2}$} & $H-201-1 A$ & 1550 & 5 & 10,000 & None & None & 11 & $680 \mathrm{~F}$ water & 0.020 \\
\hline & $\mathrm{H}-201-1 \mathrm{~B}$ & 1550 & 5 & 10,000 & None & None & 11 & $680 \mathrm{~F}$ water & 0.025 \\
\hline & $\mathrm{H}-201-2$ & 1550 & 5 & 10,000 & 1850 & 15 & 10 & $680 \mathrm{~F}$ water & 0.027 \\
\hline & $\mathrm{H}-202-\mathrm{A}$ & 1550 & 5 & 10,000 & 1650 & 240 & 9 & $680 \mathrm{~F}$ water & 0.033 \\
\hline & $H-202-B$ & 1550 & 5 & 10,000 & 1650 & 240 & 9 & $680 \mathrm{~F}$ water & 0.035 \\
\hline & $\mathrm{U}-2$ & 1550 & 4 & 10,000 & None & None & 11 & $680 \mathrm{~F}$ water & 0.008 \\
\hline & $\mathrm{U}-3$ & 1550 & 5 & 10,000 & 1650 & 1650 & 10 & $680 \mathrm{~F}$ water & 0.013 \\
\hline & & 1550 & & & & & & & \\
\hline
\end{tabular}

(a) Sectioned specimens. (Remaining specimens were defected by drilling a 0.040-in.-diameter hole through the cladding.) 
TABLE 10. CORROSION RESULTS FOR DEFECTED SPECIMENS WITH A GRAPHITE BARRIER BETWEEN THE CORE AND ZIRCALOY CLADDING

\begin{tabular}{|c|c|c|c|c|c|c|c|}
\hline \multirow[b]{2}{*}{$\begin{array}{c}\text { Fuel-Core } \\
\text { Composition, w/o }\end{array}$} & \multirow[b]{2}{*}{ Specimen } & \multicolumn{3}{|c|}{ Bonding Conditions } & \multirow[b]{2}{*}{$\begin{array}{l}\text { Duration of } \\
\text { Test, weeks }\end{array}$} & \multirow[b]{2}{*}{$\begin{array}{l}\text { Corrosion } \\
\text { Condition }\end{array}$} & \multirow{2}{*}{$\begin{array}{l}\text { Total } \\
\text { Growth, } \\
\text { in. }\end{array}$} \\
\hline & & $\begin{array}{c}\text { Temperat ure, } \\
\text { F }\end{array}$ & $\underset{\mathrm{hr}}{\text { Time, }}$ & $\begin{array}{l}\text { Pressure, } \\
\text { psi }\end{array}$ & & & \\
\hline \multirow[t]{7}{*}{$\mathrm{Al}_{2} \mathrm{O}_{3}-21 \mathrm{UO}_{2}$} & $\mathrm{H}-120-\mathrm{C}$ & 1550 & 4 & 10,000 & 12 & $750 \mathrm{~F}$ steam & 0.007 \\
\hline & $H-120-D^{(a)}$ & 1550 & 4 & 10,000 & 12 & 750 F steam & 0.015 \\
\hline & $\mathrm{H}-121-\mathrm{C}$ & 1550 & 4 & 10,000 & 12 & $750 \mathrm{~F}$ steam & 0.007 \\
\hline & $C-102-A$ & 1550 & 5 & 10,000 & 16 & $750 \mathrm{~F}$ steam & 0.003 \\
\hline & $C-102-B$ & 1550 & 5 & 10,000 & 16 & $750 \mathrm{~F}$ steam & 0.005 \\
\hline & $C-103-A$ & 1550 & 5 & 10,000 & 16 & $750 \mathrm{~F}$ steam & 0.005 \\
\hline & $C-103-B$ & 1550 & 5 & 10,000 & 16 & $750 \mathrm{~F}$ steam & 0.003 \\
\hline $\mathrm{UO}_{2}$ & $U-1-W$ & 1550 & 4 & 10,000 & 10 & $680 \mathrm{~F}$ water & 0.002 \\
\hline \multirow[t]{2}{*}{$\mathrm{Al}_{2} \mathrm{O}_{3}-21 \mathrm{UO}_{2}$} & $H-120-W$ & 1550 & 4 & 10,000 & 10 & $680 \mathrm{~F}$ water & 0 \\
\hline & $H-121-W$ & 1550 & 4 & 10,000 & 10 & $680 \mathrm{~F}$ water & 0 \\
\hline \multirow[t]{2}{*}{$\mathrm{UO}_{2}$} & $L-35^{(b)}$ & 1550 & 4 & 10,000 & 3 & $680 \mathrm{~F}$ water & 0 \\
\hline & $26 x^{(b)}$ & 1450 & 2 & 10,000 & 2 & 680 F water & 0 \\
\hline
\end{tabular}

(a) Sectioned specimen. (Remaining specimens were defected with a 0.040-in. hole.)

(b) Specimens heat treated at $1850 \mathrm{~F}$ for $5 \mathrm{~min}$. 


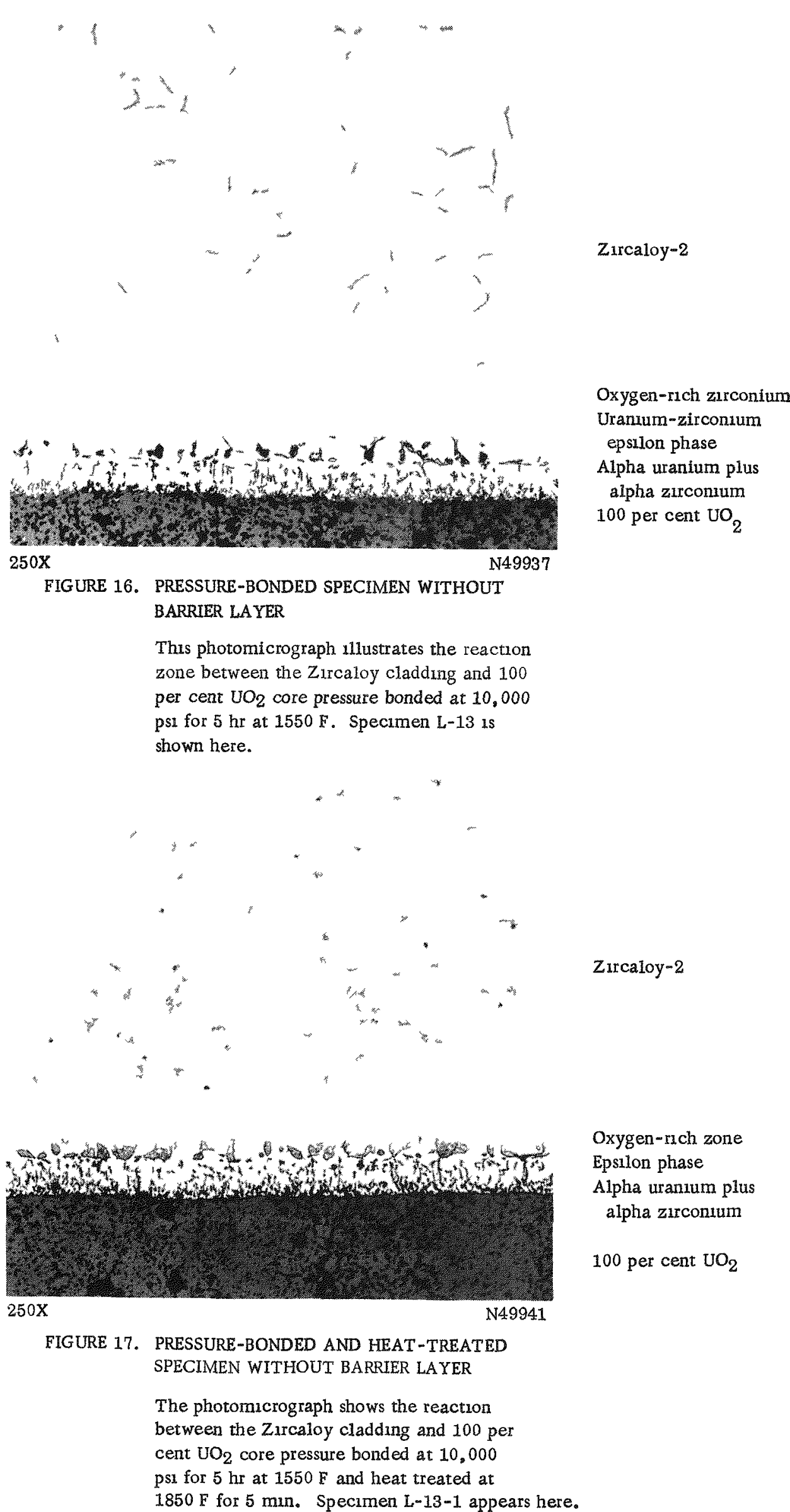




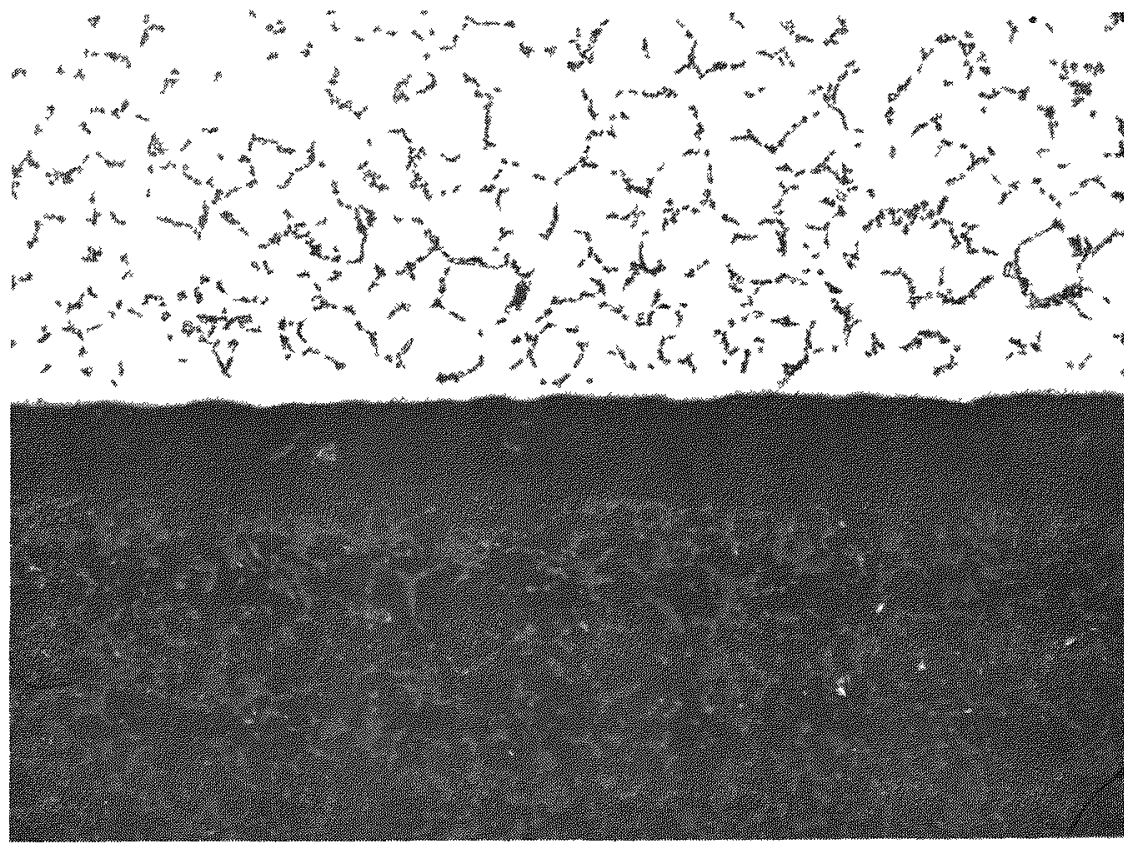

$250 \mathrm{X}$

FIGURE 18. SPECIMEN WITH GRAPHITE BARRIER LAYER

This specimen was pressure bonded at $1550 \mathrm{~F}$ and 10,000 psi for $4 \mathrm{hr}$. Specimen $\mathrm{H}-121-\mathrm{A}$ is shown.

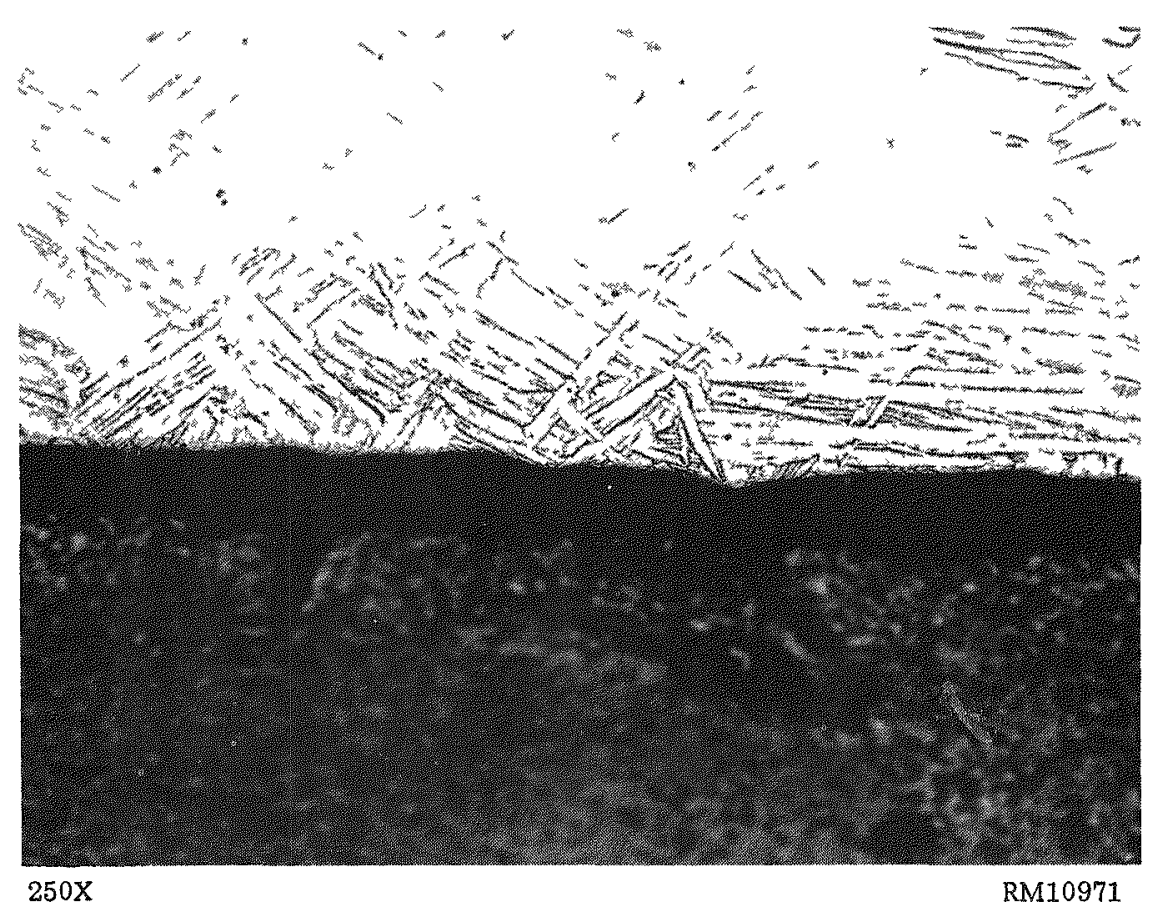

FIGURE 19. BET A-HEAT -TREATED SPECIMEN WITH GRAPHITE BARRIER LAYER

The specimen was heat treated at $1850 \mathrm{~F}$ for $5 \mathrm{~min}$ after pressure bonding at $1550 \mathrm{~F}$ and $10,000 \mathrm{psi}$ for $4 \mathrm{hr}$, Shown is Specimen $\mathrm{H}-5$.
Zircaloy-2

Graphite barmer layer

$\mathrm{Al}_{2} \mathrm{O}_{3}-21 \mathrm{w} / \mathrm{O} \mathrm{UO} 2$

\section{Zircaloy -2}

Graphite barrier layer

100 per cent $\mathrm{UO}_{2}$ 
core-to-cladding reaction, although no swelling of purposely defected compartments occurred during corrosion testing. It was determined, however, that later specimens bonded with cores coated at Bettis by spraying with Aquadag, a suspension of graphite in water, showed less reaction in metallographic examination between cladding and core after bonding and heat treating. This process of spray coating was incorporated in later studies in this program. Th1s type of coating is easy to apply and is very inexpensive. Of the barrier layers investıgated, graphite was determined to be the easiest to apply with techniques currently available and afforded consistent protection against core-tocladding reaction.

\section{Chromium Barrier}

Initially, attempts were made to vapor deposit a coating of chromium on the fuel cores to serve as a barrier, but the coatings were thin and were readily penetrated. In some areas, the chromlum prevented reaction, however, and it appeared that a thicker coating of chromium would serve as a good barrier.

Techniques were developed, therefore, for electroplating coatings of chromium on the oxide cores. Plating was accomplished by first applying a $0.003-$ mil coating of silver, followed by a $0.1-$ mil electrodeposited iron or nickel coating upon which a 0.5-mil coating of chromium was electroplated.

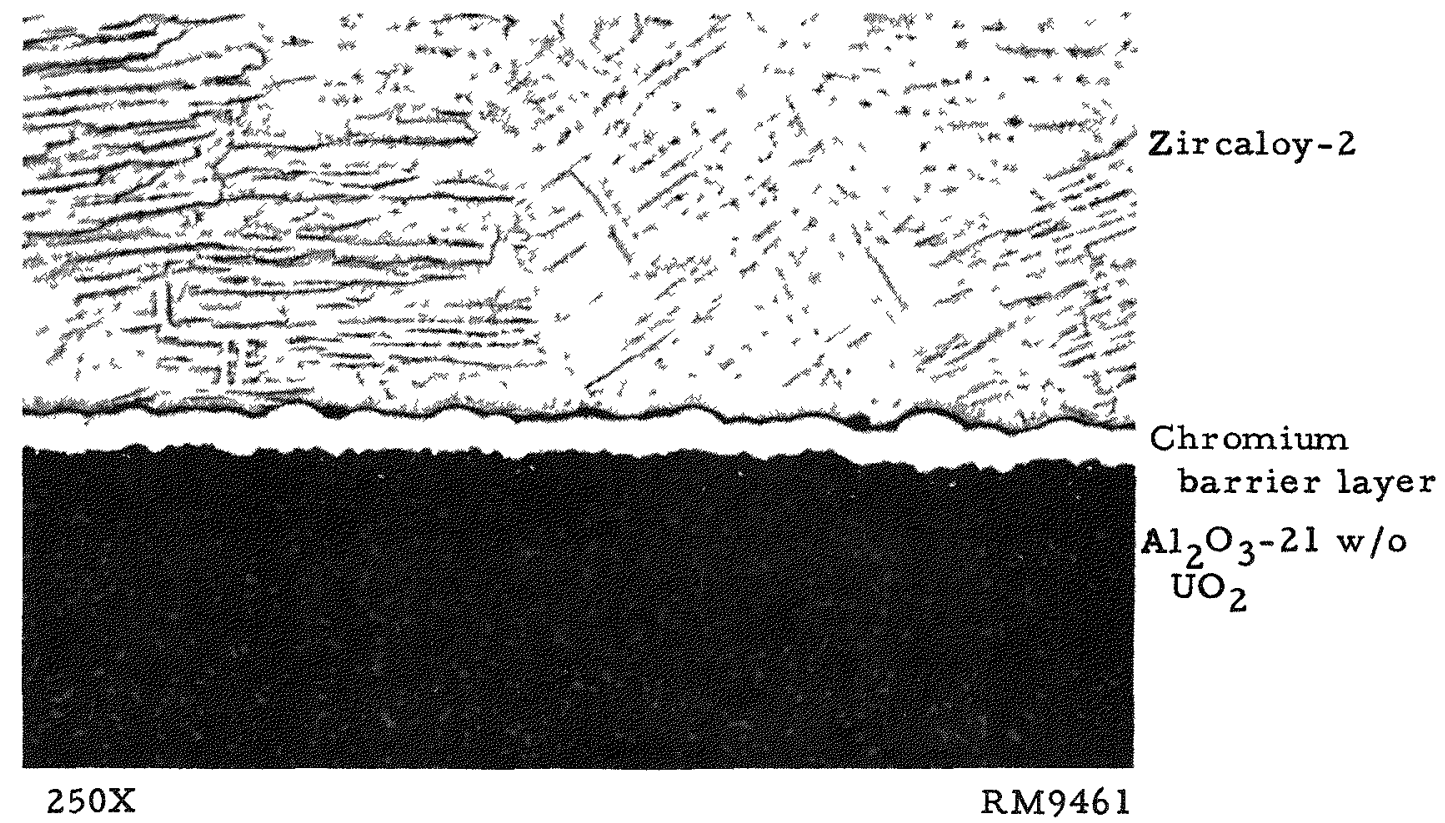

FIGURE 20. PRESSURE-BONDED AND HEAT-TREATED SPECIMEN WITH CHROMIUM BARRIER LAYER

This specimen has an electroplated chromium barrier layer between the $\mathrm{Zircaloy}-2$ cladding and $\mathrm{Al}_{2} \mathrm{O}_{3}-21$ w/o $\mathrm{UO}_{2}$ core. This specimen was pressure bonded at 10,000 psi for $4 \mathrm{hr}$ at $1500 \mathrm{~F}$ and then was heat treated at $1850 \mathrm{~F}$ for $15 \mathrm{~min}$. Specimen H-116-E appears here. 
Specimens containing 0.5-mil electroplated-chromium barriers were pressure bonded at $1500 \mathrm{~F}$. Drilled corrosion specimens in the as-bonded condition exhibited no growth in $680 \mathrm{~F}$ water or $750 \mathrm{~F}$ steam (Table 11). The chromium did not have a deleterious effect on the corrosion resistance of the Zircaloy and also possessed good corrosion resistance itself. Metallographic examinations showed no apparent reaction between the core and barrier or between the cladding and barrier during pressure bonding. A specimen heat treated at $1850 \mathrm{~F}$ for $15 \mathrm{~min}$ after pressure bonding revealed no visible reaction (Figure 20) and did not swell when corrosion tested in $680 \mathrm{~F}$ degassed water after sectioning.

\section{Iron Barrier}

The potentiality of iron as a barrier layer was initially studied using 1-mil iron foil. Later, specimens containing 0.5-mil electroplated iron barrier layers were pressure bonded using temperatures of 1500 and $1550 \mathrm{~F}$. Table 11 lists only slight or no growth in $750 \mathrm{~F}$ steam and $680 \mathrm{~F}$ water for specimens purposely defected with a 0.040 -in. hole. Sectioned specimens in $750 \mathrm{~F}$ steam showed a slight amount of swelling, although severe rusting of the iron barrier occurred. During pressure bonding at $1500 \mathrm{~F}$, the iron diffused only slightly into the cladding, and there was no visible core-barrier reaction. When pressure bonded at $1500 \mathrm{~F}$, there was a large amount of diffusion of iron into the Zircaloy (Figure 21). As shown in Figure 22, the barrier diffused away entirely during a $15-\mathrm{min}$ beta-phase anneal at $1850 \mathrm{~F}$, leaving a zirconium-rich layer containing oxygen adjacent to the core. A thin uranium-rich layer can also be noted.

\section{Nickel Barrier}

On the basis of preliminary results obtained from feasibility studies with nickel foil as a barrier, cores were coated with 0.5 to 1.5 -mil Kanigen nickel (nickel-8 w/o phosphorus) and 0.5-mil electroplated nickel barrier layers. Defected specimens which were corrosion tested in $750 \mathrm{~F}$ steam or $680 \mathrm{~F}$ water exhibited only varying amounts of growth, as can be noted in Table 11. Exposure in corrosion tests produced a large thickness increase in sectioned specimens. Observation of these corrosion specimens indicated a lamellar separation in the barrier-cladding reaction zone. There was no detrimental effect on the corrosion resistance of the cladding noted during the period of testing from the phosphorus or nickel present in the coatings. Metallographic observations revealed no reaction at the core-barrier interface and large amounts of reaction between the barrier and the cladding. It was observed that extensive diffusion of nickel occurred during a beta treatment and decreased the corrosion resistance of the interface.

\section{Miscellaneous Barriers}

Numerous other materials were investigated as diffusion barriers between Zircaloy and $\mathrm{UO}_{2}$, but none appeared as promising as graphite or chromium. The corrosion results for specimens prepared with various barrier materials are summarized in Table 12. Only slight thickness increases were recorded for defected specimens containing a molybdenum barrier. However, examination of one of these specimens showed that severe attack had occurred in the molybdenum-rich zirconium layer. A defected specimen containing a 1-mil palladium-foil barrier failed catastrophically in $750 \mathrm{~F}$ steam. A steady growth was observed for both sectioned and defected specimens 


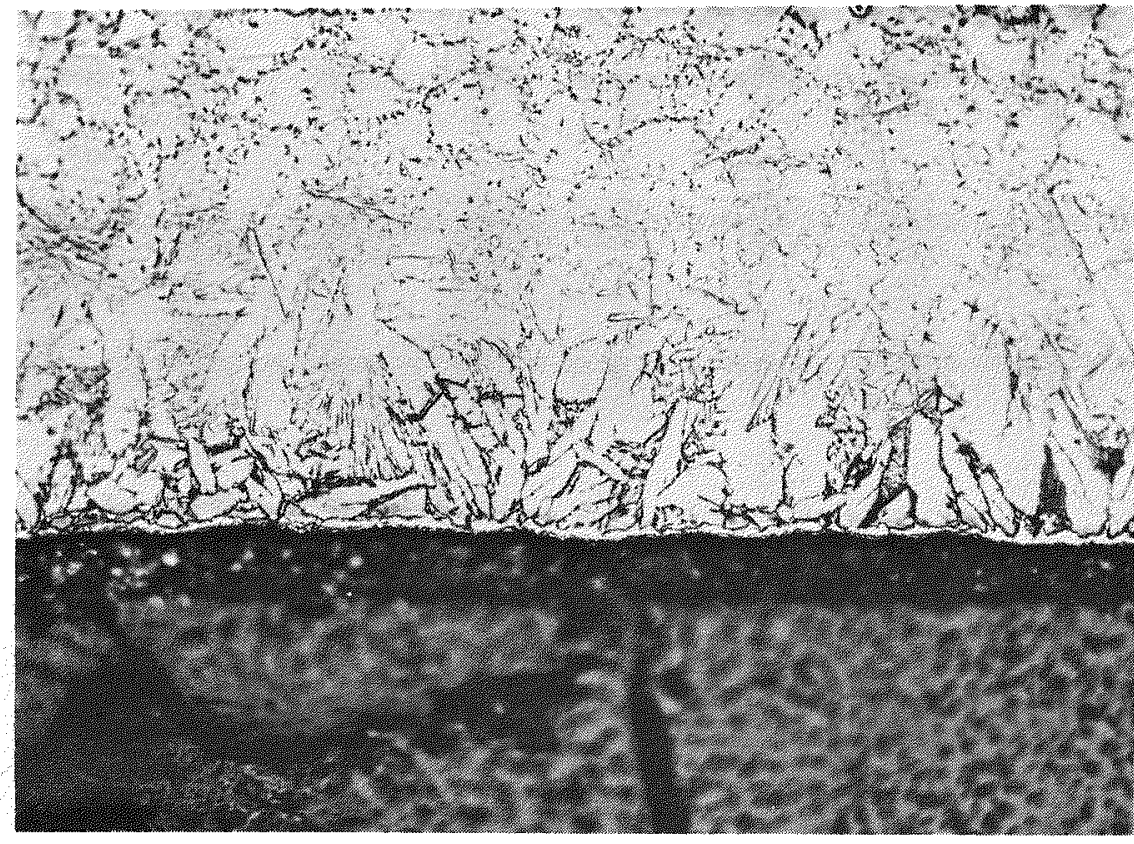

$250 \mathrm{X}$

FIGURE 21. SPECIMEN WITH IRON BARRIER LAYER

This specimen has a $0.5-$ mil electroplated iron

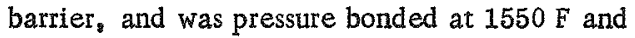
10, 000 psi for $5 \mathrm{hr}$. Shown is Specimen $\mathrm{U}^{-5}$.

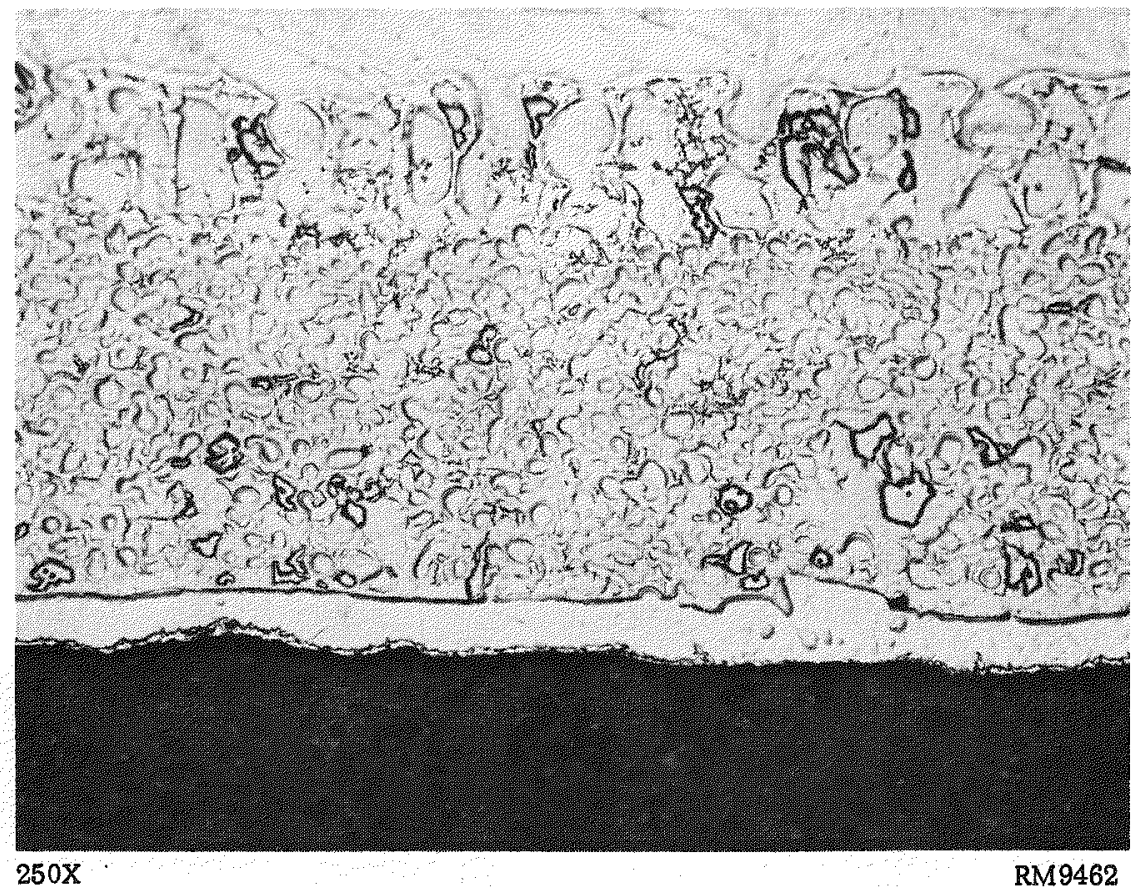

FIGURE 22. HEAT-TREATED SPECIMEN WITH IRON BARRIER LAAYER

This photomicrograph shows the reaction between an electroplated iron barrier layer and the Zircaloy-2 cladding after a beta-phase anneal at $1850 \mathrm{~F}$ for $15 \mathrm{~min}$. The specimen was pressure bonded at $1500 \mathrm{E}$ and 10,000 psi for $4 \mathrm{hr}$ prior to heat treatment. Specimen $\mathrm{H}-115-\mathrm{E}$ appears here.

Zircaloy -2

Iron $-z$ irconium reaction zone

Iron barrier layer (overetched)

100 per cent $\mathrm{UO}_{2}$

Zircaloy-2

Iron "zirconium reaction zone

Zirconium-rich layer containing oxygen Uranium-zirconium reaction zone

$\mathrm{Al}_{2} \mathrm{O}_{3}-21$ w/o UO 
TABLE 11. CORROSION RESULTS FOR DEFECTED SPECIMENS WITH CHROMIUM, IRON, AND NICKEL BARRIER LAYERS

\begin{tabular}{|c|c|c|c|c|c|c|c|c|c|c|c|c|}
\hline \multirow{3}{*}{$\begin{array}{c}\text { Fuel-Core } \\
\text { Composition, } \\
\text { w/o }\end{array}$} & \multirow[b]{3}{*}{ Specimen } & & & \multicolumn{3}{|c|}{ Bonding Conditions } & \multicolumn{3}{|c|}{ Heat Treatment } & \multirow{3}{*}{$\begin{array}{c}\text { Duration } \\
\text { of Test, } \\
\text { weeks }\end{array}$} & \multirow{3}{*}{$\begin{array}{l}\text { Corrosion } \\
\text { Condition }\end{array}$} & \multirow{3}{*}{$\begin{array}{l}\text { Total Growth } \\
\text { in. }\end{array}$} \\
\hline & & \multicolumn{2}{|c|}{ Barrier } & \multirow{2}{*}{$\begin{array}{c}\text { Temperature, } \\
\text { E }\end{array}$} & \multirow{2}{*}{$\begin{array}{c}\text { Time } \\
\mathrm{hr}\end{array}$} & \multirow{2}{*}{$\begin{array}{c}\text { Pressure } \\
\text { psï }\end{array}$} & \multirow{2}{*}{\multicolumn{2}{|c|}{$\begin{array}{c}\text { Temperature } \\
\mathrm{E}\end{array}$}} & \multirow{2}{*}{$\begin{array}{l}\text { Time, } \\
\text { min }\end{array}$} & & & \\
\hline & & Thickness, mils & Material & & & & & & & & & \\
\hline \multirow{4}{*}{$\mathrm{Al}_{2} \mathrm{O}_{3}-21 \mathrm{UO}_{2}$} & $\mathrm{H}-116^{\infty} \times \mathrm{C}$ & 0.5 & Electroplated $\mathrm{Cr}$ & 1500 & 4 & 10,000 & & None & & 12 & $750 \mathrm{~F}$ steam & None \\
\hline & $H-116-D^{(a)}$ & 0.5 & Electroplated $\mathrm{Cr}$ & 1500 & 4 & 10,000 & & None & & 12 & $750 \mathrm{~F}$ steam & 0.006 \\
\hline & $H-116-W$ & 0.5 & Electroplated $\mathrm{Cr}$ & 1500 & 4 & 10,000 & & None & & 11 & $680 \mathrm{E}$ water & None \\
\hline & $H-116-B^{(a)}$ & 0.5 & Electroplated $\mathrm{Cr}$ & 1500 & 4 & 10,000 & 1850 & & 15 & 5 & $680 \mathrm{~F}$ water & None \\
\hline \multirow{6}{*}{$\mathrm{Al}_{2} \mathrm{O}_{3}-21 \mathrm{UO}_{2}$} & $\mathrm{H}-105-\mathrm{C}$ & 1.0 & Fe foil & 1500 & 5 & 10,000 & & None & & 16 & $750 \mathrm{~F}$ steam & None \\
\hline & $H-105-D^{(a)}$ & 1.0 & Fe foil & 1500 & 5 & 10,000 & & None & & 16 & 750 E steam & 0.006 \\
\hline & $\mathrm{H}-115-\mathrm{C}$ & 0.5 & Electroplated $\mathrm{Fe}$ & 1500 & 4 & 10,000 & & None & & 12 & $750 \mathrm{~F}$ steam & None \\
\hline & $H-115-D^{(a)}$ & 0.5 & Electroplated $\mathrm{Fe}$ & 1500 & 4 & 10,000 & & None & & 12 & $750 \mathrm{~F}$ steam & 0.006 \\
\hline & $\mathrm{H}-105-\mathrm{W}$ & 1.0 & Fe foil & 1500 & 5 & 10,000 & & None & & 11 & $680 \mathrm{~F}$ water & 0.004 \\
\hline & $H-115-W$ & 0.5 & Electroplated $\mathrm{Fe}$ & 1500 & 4 & 10,000 & & None & & 11 & $680 \mathrm{~F}$ water & None \\
\hline $\mathrm{UO}_{2}$ & $\mathrm{U}-5^{(a)}$ & 0.5 & Electroplated $\mathrm{Fe}$ & 1550 & 5 & 10,000 & & None & & 5 & $680 \mathrm{~F}$ water & None \\
\hline \multirow{12}{*}{$\mathrm{Al}_{2} \mathrm{O}_{3}-21 \mathrm{UO}_{2}$} & $\mathrm{H}-106-\mathrm{C}$ & 1.0 & Ni foil & 1500 & 5 & 10,000 & & None & & 16 & $750 \mathrm{~F}$ steam & 0.011 \\
\hline & $H-106-D^{(a)}$ & 1.0 & Ni foil & 1500 & 5 & 10,000 & & None & & 16 & $750 \mathrm{~F}$ steam & 0.040 \\
\hline & $\mathrm{H}-111-\mathrm{C}$ & 0.5 & Kanigen $\mathrm{Ni}$ & 1550 & 4 & 10,000 & & None & & 15 & $750 \mathrm{~F}$ steam & 0.002 \\
\hline & $\mathrm{H}-112-\mathrm{C}$ & 1.0 & Kanigen Ni & 1550 & 4 & 10,000 & & None & & 15 & $750 \mathrm{~F}$ steam & 0.002 \\
\hline & $\mathrm{H}-113-\mathrm{C}$ & 1.5 & Kanigen Ni & 1550 & 4 & 10,000 & & None & & 15 & $750 \mathrm{~F}$ steam & 0.002 \\
\hline & $\mathrm{H}-117-\mathrm{C}$ & 0.5 & Electroplated Ni & 1500 & 4 & 10,000 & & None & & 12 & $750 \mathrm{~F}$ steam & 0.010 \\
\hline & $H-117-D^{(a)}$ & 0.5 & Electroplated $\mathrm{Ni}$ & 1500 & 4 & 10,000 & & None & & 12 & $750 \mathrm{~F}$ steam & 0.027 \\
\hline & $\mathrm{H}-117-\mathrm{W}$ & 1.0 & Ni foil & 1500 & 5 & 10,000 & & None & & 11 & $680 \mathrm{~F}$ water & 0.003 \\
\hline & $H-111-W$ & 0.5 & Kanigen $\mathrm{Ni}$ & 1550 & 4 & 10,000 & & None & & 11 & $680 \mathrm{~F}$ water & None \\
\hline & $H-112-W$ & 1.0 & Kanigen $\mathrm{Ni}$ & 1550 & 4 & 10,000 & 1850 & & 15 & 10 & $680 \mathrm{~F}$ water & 0.003 \\
\hline & $H-113-W$ & 1.5 & Kanigen $\mathrm{Ni}$ & 1550 & 4 & 10,000 & 1850 & & 15 & 10 & $680 \mathrm{~F}$ water & 0.013 \\
\hline & $H-117-W$ & 0.5 & Electroplated Ni & 1500 & 4 & 10,000 & & None & & 11 & $680 \mathrm{~F}$ water & None \\
\hline $\mathrm{UO}_{2}$ & $U-4^{(a)}$ & 0.5 & Electroplated Ni & 1550 & 5 & 10,000 & & None & & 5 & $680 \mathrm{~F}$ water & None \\
\hline
\end{tabular}

(a) Sectioned specimens. (Remaining specimens were defected with 0.040 -in. drilled holes.) 
TABLE 12. CORROSION RESULTS FOR DEFECTED SPECIMENS WITH MISCELLANEOUS BARRIERS BETWEEN THE A1 ${ }_{2} \mathrm{O}_{3}^{-21} \mathrm{w} / \mathrm{O} \mathrm{UO}_{2}$ CORE AND THE ZIRCALOY CLADDING

Specimens were not beta heat treated after bonding.

\begin{tabular}{|c|c|c|c|c|c|c|c|}
\hline \multirow[b]{2}{*}{ Specimen } & \multirow[b]{2}{*}{ Barrier } & \multicolumn{3}{|c|}{ Bonding Conditions } & \multirow[b]{2}{*}{$\begin{array}{l}\text { Duration of } \\
\text { Test, weeks }\end{array}$} & \multirow[b]{2}{*}{$\begin{array}{l}\text { Corrosion } \\
\text { Conditions }\end{array}$} & \multirow{2}{*}{$\begin{array}{c}\text { Total } \\
\text { Growth, } \\
\text { in. }\end{array}$} \\
\hline & & $\begin{array}{c}\text { Temperature, } \\
F\end{array}$ & $\begin{array}{l}\text { Time, } \\
\text { hr }\end{array}$ & $\begin{array}{c}\text { Pressure, } \\
\text { psi }\end{array}$ & & & \\
\hline $\mathrm{H}-107-\mathrm{C}$ & $\begin{array}{l}\text { Niobium } \\
(0.001 \text { in.) }\end{array}$ & 1550 & 5 & 10,000 & 16 & $750 \mathrm{~F}$ steam & 0.021 \\
\hline$H-107-D^{(a)}$ & $\begin{array}{l}\text { Niobium } \\
(0.001 \text { in. })\end{array}$ & 1550 & 5 & 10,000 & 16 & $750 \mathrm{~F}$ steam & 0.022 \\
\hline $\mathrm{H}-103-\mathrm{B}$ & $\begin{array}{r}\text { Molybdenum } \\
(0.001 \text { in. })\end{array}$ & 1550 & 5 & 10,000 & 16 & $750 \mathrm{~F}$ steam & 0.004 \\
\hline $\mathrm{H}-108-\mathrm{C}$ & $\begin{array}{l}\text { Magnesium } \\
\text { oxide }\end{array}$ & 1550 & 5 & 10,000 & 15 & $750 \mathrm{E}$ steam & 0.051 \\
\hline $\mathrm{H}-109-\mathrm{C}$ & Thorium oxide & 1550 & 5 & 10,000 & 15 & $750 \mathrm{~F}$ steam & 0.030 \\
\hline $\mathrm{H}-110-\mathrm{C}$ & $\begin{array}{l}\text { Zirconium } \\
\text { oxide }\end{array}$ & 1550 & 4 & 10,000 & 15 & $750 \mathrm{~F}$ steam & 0.036 \\
\hline $\mathrm{H}-102-\mathrm{W}$ & $\begin{array}{l}\text { Palladium } \\
(0.001 \text { in. })\end{array}$ & 1550 & 5 & 10,000 & 15 & $680 \mathrm{~F}$ water & 0.040 \\
\hline$H-103-W$ & $\begin{array}{r}\text { Molybdenum } \\
(0.001 \text { in. })\end{array}$ & 1550 & 5 & 10,000 & 15 & $680 \mathrm{~F}$ water & 0.005 \\
\hline
\end{tabular}

(a) Sectioned specimens. (Remaining specimens were defected with 0.040-in. holes). 
containing niobium-foil barrier layers in $750 \mathrm{~F}$ steam. These specimens showed considerable diffusion between the niobium and the Zircaloy. This niobium-rich layer was severely attacked during the exposure; however, the low purity of the niobium foil employed was probably the cause of the corrosion attack.

Coatings of $\mathrm{ZrO}_{2}, \mathrm{ThO}_{2}$, and $\mathrm{MgO}$ were applied to $\mathrm{Al}_{2} \mathrm{O}_{3}-21 \mathrm{w} / 0 \mathrm{UO}_{2}$ cores by use of water and lacquer slurries and fired in hydrogen up to $2600 \mathrm{~F}$. All of the coatings were porous and tended to flake. Specimens containing these oxide coatings were pressure bonded, defected, and corrosion tested in $750 \mathrm{~F}$ steam. A large thickness increase was observed for all of the specimens during corrosion testing. Metallographic examination indicated large amounts of oxygen diffusion into the cladding and thin uraniumrich reaction zones along the interface. In all specimens, bonding was erratic as a result of flaking of the oxide layers and contamination of the Zircaloy-Zircaloy interface.

The results of the study of core-cladding reaction indicated that a barrier would be required to prevent reaction during pressure bonding and beta heat treating. The data from the barrier-layer investigation showed that a coating of either graphite or chromium on the cores was satisfactory as a barrier during both pressure bonding and beta heat treating. Graphite is the most economical barrier layer and the easiest to apply with consistent results by techniques available at the present time. 


\section{DEVELOPMENT OF PROCESS FOR GAS-PRESSURE BONDING OF FUEL ELEMENTS UTILIZING PROTECTIVE CONTAINERS}

A series of flat-plate Zircaloy-clad fuel elements containing compartmentalized uranium dioxide cores was pressure bonded, incorporating the techniques developed in previous phases of the program, in order to obtain a comprehensive evaluation of the procedures used. The components for these elements, with accompanying Ti-Namel spacers, were assembled into Ti-Namel containers for bonding. The cladding components for these elements were surface finished by machine belt abrading using 60-grit silicon carbide belts operating at a speed of $2200 \mathrm{ft}$ per min with sulfonated oil coolant. To prevent core-cladding reaction, the uranium dioxide cores were coated with graphite, using Neolube as described earlier. The Ti-Namel spacers placed between the TiNamel container and the cladding plates were plated with a $0.3-\mathrm{mil}$ coating of chromium in an attempt to avoid diffusion of iron into the Zixcaloy-2. Several of the later elements contained a stainless steel shim between the cladding plates and spacers to prevent or minimize diffusion of iron.

The components for these elements are shown ready for assembly in Figure 2. The approximate over-all size of the elements was 11.25 by $2.5 \mathrm{in}$. with a thickness of $0.120 \mathrm{in.}$, consisting of two 0.020-in. -thick cladding plates and an 0.080-in. -thick compartmented picture frame. Each element contained nine fuel compartments, 3 by 0.5 in. , separated from each other by Zircaloy ribs either 0.040 or 0.060 in. wide. Two cores half the length of a compartment were inserted into each compartment. The picture frames for these elements were prepared in one piece by punching out the compartment areas and then abrading the frame to final thickness, except for several elements which were prepared using a pieced picture frame assembled from surface-prepared strip components.

Pressure bonding was performed at 10,000 psi for $4 \mathrm{hr}$ using temperatures from 1450 to $1550 \mathrm{~F}$. Most of the pressure-bonded elements were heat treated at $1850 \mathrm{~F}$ for 5 min in a barium chloride salt bath and quenched in a stream of helium; a few elements were tested without this treatment. After heat treatment, the specimens were vapor blasted and pickled in a hydrofluoric acid solution. The tests employed to evaluate these elements included visual examination, metallographic examination of bond quality and core-cladding reaction, peel tests of bonds, intercompartmental leakage tests, burst tests of compartments, corrosion of purposely defected compartments, waterlogging tests, corrosion of the Zircaloy-2 cladding, and chemical analyses.

\section{TEST PROCEDURES}

A diagram of an element is shown in Figure 23, indicating the sectioning and defecting of specimens for the various tests and examinations. The fuel compartments were arbitrarily numbered and simulated defects, $0.005 \mathrm{in}$. in diameter, were drilled into the cores in selected compartments for the various tests, as indicated. Holes were drilled to a depth of $0.025 \mathrm{in}$. to insure penetration to the cores. Examination of the holes with a light microscope was used to establish if the defects extended into the cores. The samples for metallographic examination, peel tests, and Zircaloy corrosion tests were removed from the portion of the intercompartmental-leakage-test specimens which 


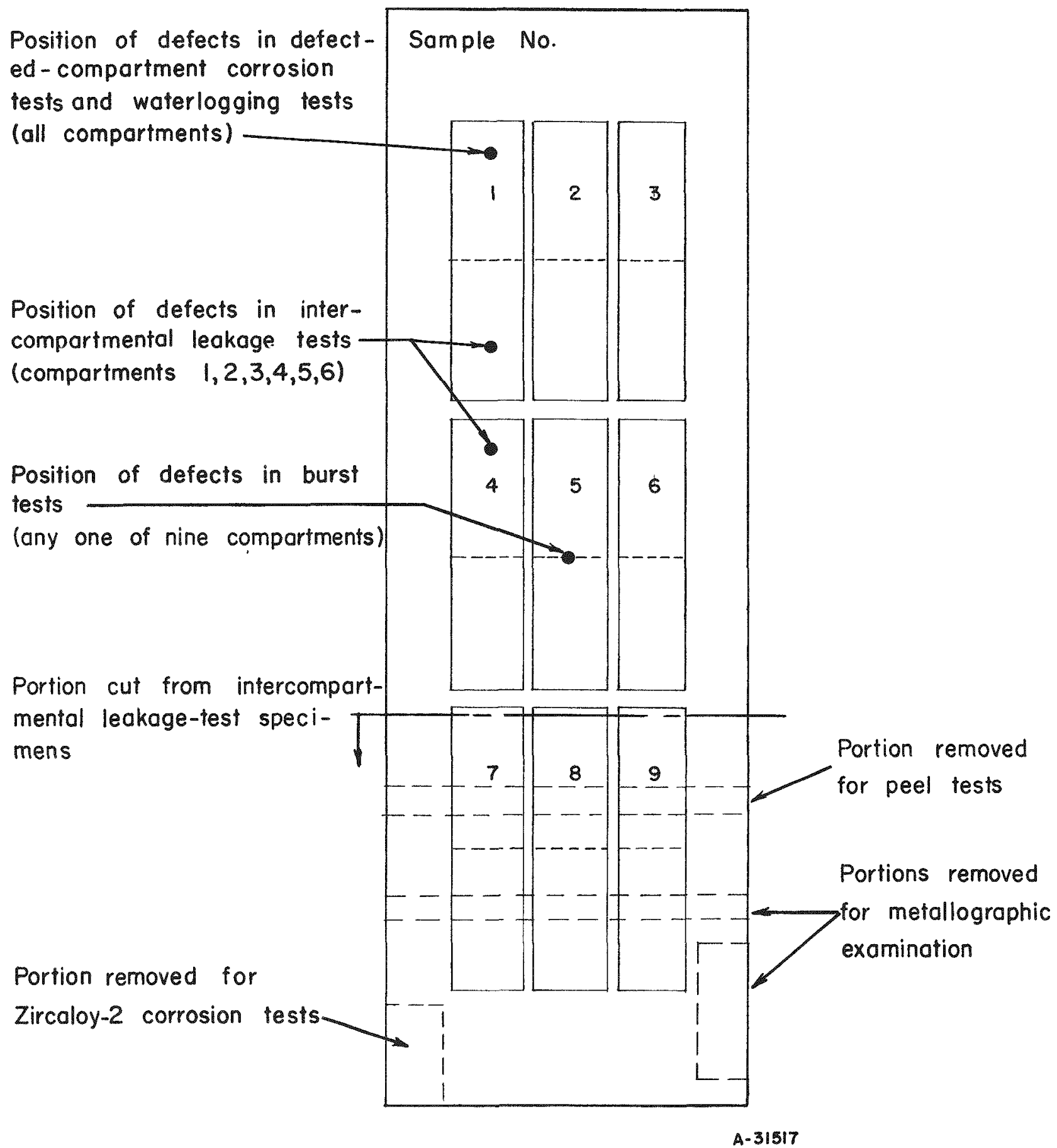

FIGURE 23. PREPARATION OF ELEMENTS FOR EVALUATION 
was cut off, as shown in Figure 23. The remaining six compartments of these elements were then tested for intercompartmental leakage.

\section{Metallographic Examination}

Cross-sectional and edge samples of the specimens were removed as indicated in Figure 23 for metallographic examination of bond quality and extent of core-cladding reaction. Light microscopes with polarized and bright-field illumination were used with magnifications of 100,250 , and 500X. Bonds were classified by the percentage of areas with Types $A, B$, and $C$ bonds, as described in a previous section and shown in Figure 3. Bond interfaces were examined for oxygen-rich layers along the interface, extensive iron diffusion, hydride needles, and the presence of inclusions of graphite from the graphite-coated cores. The cladding was examined for core-to-cladding reaction products, for iron or chromium contamination from the chromium-plated $T i-N a m e l$ spacers, and for hydrogen contamination. The thickness of the cladding as a function of dimensional control of the surface-prepared and assembled element was also studied.

\section{Peel Tests of Bonds}

Cross-sectional portions of elements (Figure 23) were peel tested to determine the strength of the bonds along the ribs and edges. The bonds between the ribs of the picture frames and the cladding plates were tested by driving a wedge into the exposed compartments; the strength of the bonds at the edges of the elements was determined by driving a chisel into a $\mathrm{V}$-notch which had been filed into the bond interface at the edge of the specimen. A good test was considered one in which rupture of the cladding material occurred instead of separation of the bond.

\section{Burst Tests}

Compartments of elements were burst tested in order to indicate the relative strength and ductility of the cladding and strength of the bond. In this test, one compartment of an element was subjected to increasing internal pressure until rupture of the cladding occurred. The pressure required to produce rupture and the amount of deflection of the cladding before rupture were recorded. It was also noted if any of the bonds between the cladding plates and the ribs of the picture frame failed during the test.

Defects were drilled in these elements in the center of the compartment as shown in Figure 23, which placed the hole between the two cores in the compartment. The tests were conducted in a jig designed to permit the application of gas pressure into the defected compartment. The pressure was applied through a 1/4-in.-diameter probe with a rubber O-ring seal around the 0.005-in. defect. Metal plates were placed on both sides of the element. The front plate had a 1/4-in. opening to admit the probe. The back plate had a 3 by 1/2-in. opening over the compartment to be tested. The two plates and test specimen were clamped to a supporting frame and helium gas pressure was applied in 100-1b increments. As bulging occurred, the deflection of the back side of the compartment under test was read from a dial gage. After deflection ceased, there was a 15-sec delay before the next 100-1b increment of pressure was applied. 
Corrosion Tests of Defected Compartments

Corrosion tests were conducted to determine the resistance of purposely defected. compartments to attack in $680 \mathrm{~F}$ degassed water. If core-cladding reaction had occurred, it was evidenced by attack at the interface and swelling of the compartments. These elements were defected with 0.005 -in. holes located about $1 / 4$ in. from the top end of all nine of the compartments, as shown in Figure 23. Evaluation was on the basis of changes in thickness, weight, and general appearance.

Intercompartmental-Leakage Tests

Specimens were tested for intercompartmental leakage in order to evaluate the integrity of the bonding between the ribs of the picture frame and the cladding plates. There were only six compartments in these specimens; remaining portions were removed for other tests. Defects were drilled into the center of the bottom core in Compartments 1, 2, and 3 and in the center of the top core in Compartments 4, 5, and 6 (Figure 23). A helium pressure of $700 \mathrm{psi}$ was applied successively to the defects in Compartments 1, 3, and 5 using the same apparatus as was employed in the burst tests. The front masking plate was not used in order to permit painting of the five exposed defects with soap solution. Bubbles over a defect revealed a leak between compartments resulting from imperfect bonding between the cladding plates and picture frame. The specimens were tested before and after corrosion testing in $680 \mathrm{~F}$ water; they were evaluated on the basis of intercompartmental leakage and behavior during corrosion.

\section{Waterlogging Tests}

Tests were conducted on several elements to detect waterlogging of the compartmented cores. Defects were drilled into the center of the bottom core in each of the nine compartments. The specimens were weighed and measured prior to and after corrosion testing for $18 \mathrm{hr}$ in $680 \mathrm{~F}$ water. After drying for $15 \mathrm{~min}$ at $140 \mathrm{~F}$ subsequent to corrosion testing, the elements were plunged into molten lead at 650 to $700 \mathrm{~F}$. If the compartments contained entrapped water (waterlogged), the water turned to steam, and the pressure generated resulted in bulging of the Zircaloy cladding.

Zircaloy -2 Corrosion Tests

The general corrosion resistance of the Zircaloy- 2 was evaluated from coupons taken from the corner of the piece cut from the leak-test specimens, as shown in Figure 23. The coupon consisted of Zircaloy-2 cladding plates bonded to the Zircaloy -2 picture frame, and did not contain fuel. Specimens were shaper finished on the edges and pickled in 5 parts $\mathrm{HF}-45$ parts $\mathrm{HNO}_{3}-50$ parts $\mathrm{H}_{2} \mathrm{O}$ (by volume) prior to corrosion testing in $750 \mathrm{~F}$ steam at $1500 \mathrm{psi}$. Specimens were evaluated on the basis of weight change and general appearance.

Bend Tests

Bend-test samples were prepared from various portions of the Zircaloy cladding from elements exhibiting any erratic test results as determined by the aforementioned 
testing methods. The bend tests were conducted by successively bending the sample through a 90-deg angle on dies with decreasing radii until failure occurred The $T$ value for each test was equal to the radius of the die divided by the thickness of the sample. The radius value employed was based on the last die used when the specimen did not fail.

\section{$\underline{X-R a y ~ T e s t s ~}$}

Elements were subjected to radiographic analysis to determine if transport of uranium oxide had occurred during handling of the element prior to the bonding operation. X-ray analysis was initiated late in the program; consequently, the radiographs were made of as-bonded elements or of bonded specimens that failed in an erratic manner in other tests. The radiographs were made with a power level of $180 \mathrm{kv}$.

\section{Hardness Tests}

Specimens exhibiting core-cladding reaction and oxygen-rich alpha layers of Zircaloy along the cladding-to-rib interface were subjected to microhardness tests to determine the hardness of the reaction layers and the extent of the reaction layers. Hardness values were also determined for the cladding over the core and the cladding over the frame at the ends of the specimens.

\section{TEST RESULTS}

\section{General Evaluation}

A large number of the 75 elements prepared in Ti-Namel containers for processfeasibility studies exhibited exratic results during testing. Erratic test properties were normally observed as cladding embrittlement experienced during decanning, intercompartmental leaks during burst testing or intercompartmental leak tests, brittle cladding failure during burst testing, inconsistent corrosion as a result of erratic core-tocladding reaction, and major inclusions between cladding and rib as observed during radiographic evaluations.

One of the 75 elements that was bonded during this feasibility-of-process evaluation is shown in Figure 24. The flow obtained during pressure bonding is evidenced by the deformation along the Zircaloy ribs separating the oxide fuel cores. All of the specimens bonded contained undersized ribs; consequently, most of the deformation that was obtained was across the rib area. The amount of deformation and cladding thinning is governed by the dimensional control imposed on the fuel-element cores and the Zircaloy receptacle. If normal tolerances are maintained on the cores, cladding plates, and receptacle, and if the cores are not chipped, the effect of thinning of the cladding is minor.

During the preparation of these specimens, the holes to receive the cores were punched in the Zircaloy picture frames before the frames were belt abraded. It was observed after abrading that this had resulted in uneven metal removal from the ribs, 

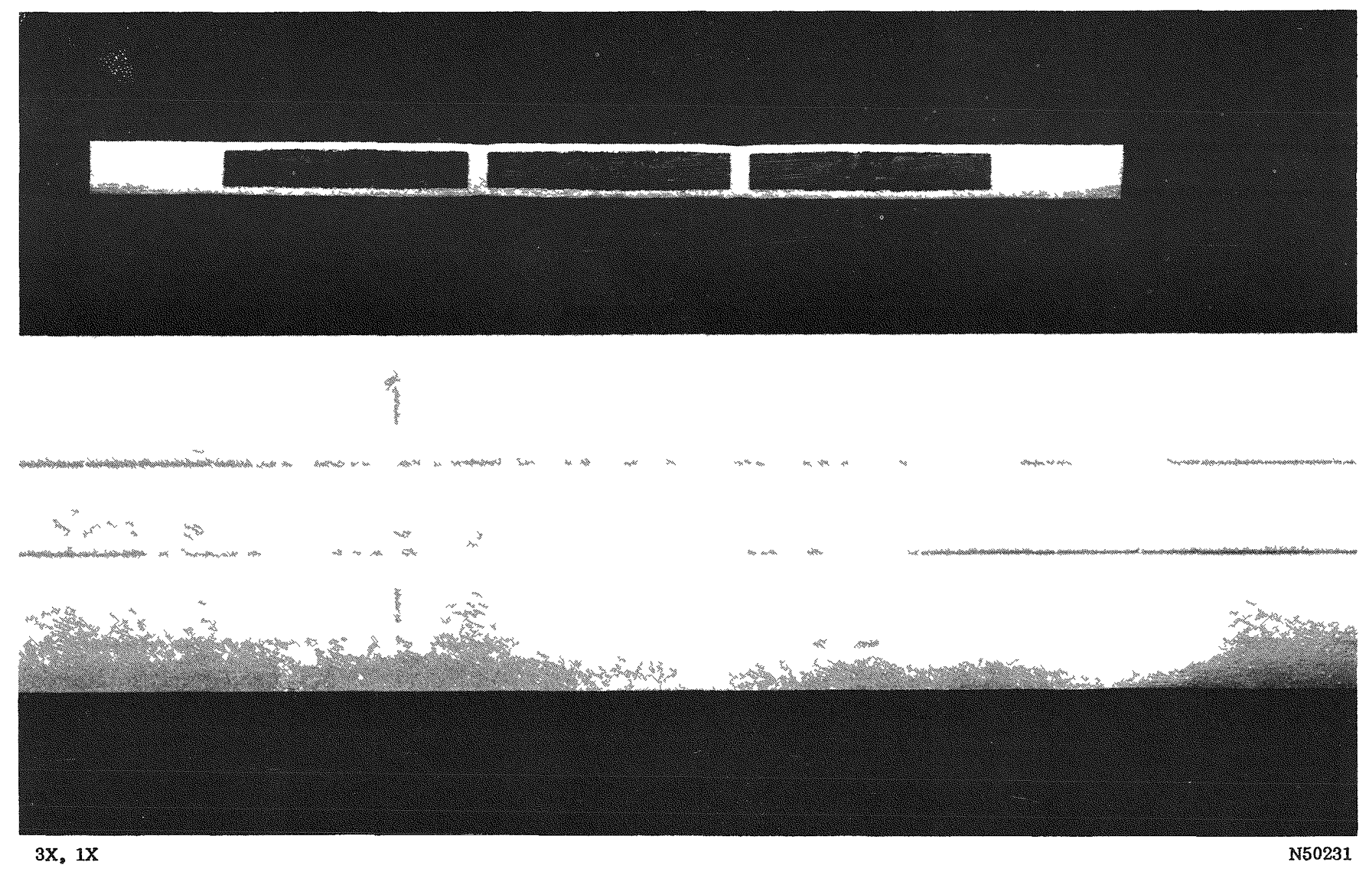

FIGURE 24. ZIRCALOY-CLAD FLAT-PLATE UO 2 FUEL ELEMENT PRESSURE BONDED IN A PROTECTIVE CONTAINER FOR 4 HR AT $1550 \mathrm{~F}$ WITH A 10,000-PSI HELIUM PRESSURE

Fragmentation of the $\mathrm{UO}_{2}$ core occurred during the machining operation. 
which were easily deflected and twisted during the finishing operation. Some areas of the ribs were not abraded at all and others were reduced excessively in thickness. It would be more desirable to abrade the picture frame before punching the holes in order to obtain a uniform surface finish and improved tolerances.

A number of the elements pressure bonded in protective cans exhibited brittle failure of a portion of the cladding when the elements were separated from the Ti-Namel spacers and the protective can after bonding. Core-cladding reaction was also obsexved to be severe in many of the specimens subjected to intercompartmental leakage, corrosion, and burst tests. A complete evaluation was made of all specimens to determine the causes of the erratic test results and to determine if these causes of failure could be eliminated by a revision of the pressure-bonding process.

\section{Metallographic Examination}

Pretest metallographic examination was made on a large number of the specimens along the longitudinal edge of the element and across the cores and ribs of the element. Prior to testing, none of the metallographic evaluations could be made near the rib areas in the portions of the elements to be leak and burst tested, since this would ruin the adjoining compartment for further testing; consequently, the results of the metallographic studies included in Table 13 do not indicate cladding plate-to-rib bond characteristics in the areas which were tested for intercompartmental leakage. The major portion of the bonds, as indicated in Table 13, were Type A, which is an excellent metallurgical bond, as shown in Figure 25. The "spots" of Type C bond noted in the table were small, isolated areas which were found by repolishing to be very shallow. Metallographic examinations of portions of specimens which had exhibıted intercompartmental leakage revealed a prevalence of Type $\mathrm{C}$ bond along the rib-to-cladding plate interface. The occurrence of Type $C$ bond was believed due in part to the difficulty of abrading the frames after punching. This resulted in improper abrading of the rib, causing excessive metal removal along the rib or lack of surface pxeparation as a result of insufficient metal removal. An additional observed cause of intercompartmental leakage was the presence of particles of oxide and graphite between the cladding plate and rib. This oxide and graphite were transported to the rib areas during handling of the assembled fuel element prior to bonding or during excessive flow of the cladding during bonding. An edge effect manifested by a poor bond extending a short distance from the edges and ends was observed in most of the specimens. The maximum depth of such a zone was observed to be about $1 / 8 \mathrm{in}$. at the edges and $1 / 4 \mathrm{in}$. at the ends. The edges and ends of all of the specimens had good bond integrity inside this area.

Specimens with cores which had not been coated with graphite to prevent corecladding reaction revealed a 0.002 to 0.003 -in. reaction zone. Graphite-coated cores properly prepared did not appear to have reacted with the cladding (Figure 26). How ever, some areas along the interface, especially at the corners of most of the cores, showed narrow regions of Zircaloy with a high oxygen content.

Peel Tests of Bonds

Table 14 contains the data from the peel tests. The strength of the bonds between the picture-frame ribs and the cladding plates was found to be good in most of the specimens. However, in many of the specimens, there were poorly bonded areas along the edges extending up to $1 / 8 \mathrm{in}$. in toward the center of the element, as shown in the table. 


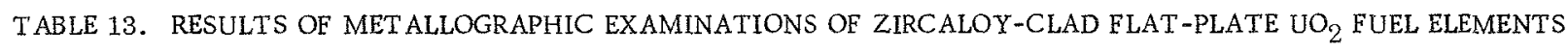

\begin{tabular}{|c|c|c|c|c|c|c|c|c|c|c|c|c|}
\hline \multirow[b]{2}{*}{ Specimen } & \multirow[b]{2}{*}{$\begin{array}{l}\text { Core } \\
\text { Coating }\end{array}$} & \multicolumn{3}{|c|}{ Pressure-Bonding Conditions } & \multicolumn{2}{|c|}{ Heat Treatment } & \multirow[b]{2}{*}{$\begin{array}{l}\text { Specimen } \\
\text { Location }\end{array}$} & \multirow{2}{*}{$\begin{array}{l}\text { Iron- } \\
\text { Reaction, } \\
\text { Depth, } \\
\text { in. }\end{array}$} & \multicolumn{3}{|c|}{ Bond Results } & \multirow{2}{*}{$\begin{array}{c}\text { Edge- } \\
\text { Effect } \\
\text { Depth, } \\
\text { in. }\end{array}$} \\
\hline & & $\begin{array}{l}\text { Time, } \\
\mathrm{hr}\end{array}$ & $\begin{array}{l}\text { Temperature, } \\
\text { F }\end{array}$ & $\begin{array}{l}\text { Pressure, } \\
\text { psi }\end{array}$ & $\begin{array}{l}\text { Time, } \\
\text { min }\end{array}$ & $\begin{array}{c}\text { Temperature, } \\
\text { F }\end{array}$ & & & $\begin{array}{l}\text { Type A, } \\
\text { per cent }\end{array}$ & $\begin{array}{l}\text { Type B, } \\
\text { per cent }\end{array}$ & $\begin{array}{l}\text { Type C, } \\
\text { per cent }\end{array}$ & \\
\hline $\mathrm{P}-1$ & None & 4 & 1500 & 10,000 & 5 & 1850 & Entire edge & None & 60 & 40 & -- & -- \\
\hline $\mathrm{p}-2$ & None & 4 & 1500 & 10,000 & 5 & 1850 & Entire edge & None & 90 & 10 & -- & -- \\
\hline $\mathrm{P}-3$ & None & 4 & 1550 & 10,000 & 5 & 1850 & Entire edge & None & 70 & 30 & -- & -- \\
\hline \multirow[t]{2}{*}{$\mathrm{p}-4$} & None & 4 & 1550 & 10,000 & 5 & 1850 & Edge & None & 99 & 1 & -- & -- \\
\hline & & & & & & & Cross section & None & 100 & -- & -- & None \\
\hline \multirow[t]{2}{*}{$P-5$} & Graphite & 4 & 1550 & 10,000 & 5 & 1850 & Edge & None & 90 & 10 & -- & -- \\
\hline & & & & & & & Cross section & None & 90 & 10 & -- & $1 / 16$ \\
\hline \multirow[t]{2}{*}{$P-6$} & None & 4 & 1550 & 10,000 & 5 & 1850 & Edge & None & 95 & 5 & -- & -- \\
\hline & & & & & & & Cross section & None & 95 & 5 & - & $1 / 16$ \\
\hline \multirow[t]{2}{*}{$\mathrm{P}-8$} & None & 2 & 1550 & 10,000 & No & & Edge & 0.003 & 90 & 10 & Spots & -- \\
\hline & & & & & & & Cross section & 0.003 & 90 & 5 & 5 & $1 / 8$ \\
\hline \multirow[t]{2}{*}{$\mathrm{P}-9$} & None & 4 & 1550 & 10,000 & No & & Edge & 0.007 & 10 & 90 & Spots & -- \\
\hline & & & & & & & Cross section & 0.007 & 10 & 90 & -- & $1 / 64$ \\
\hline \multirow[t]{2}{*}{$\mathrm{P}-10$} & None & 4 & 1550 & 10,000 & 5 & 1850 & Edge & None & 99 & 1 & - & -- \\
\hline & & & & & & & Cross section & None & 95 & 5 & -- & $1 / 64$ \\
\hline \multirow[t]{2}{*}{$P-11$} & Graphite & 4 & 1550 & 10,000 & 5 & 1850 & Edge & None & 95 & 5 & -- & -- \\
\hline & & & & & & & Cross section & None & 90 & 10 & -- & $1 / 64$ \\
\hline \multirow[t]{2}{*}{$P-14$} & Graphite & 4 & 1550 & 10,000 & 5 & 1850 & Edge & None & 90 & 10 & -- & -- \\
\hline & & & & & & & Cross section & None & 95 & 5 & -- & $1 / 16$ \\
\hline \multirow[t]{2}{*}{$P-21$} & Graphite & 4 & 1550 & 10,000 & \multirow{2}{*}{\multicolumn{2}{|c|}{ None }} & Edge & None & 80 & 20 & Spots & -- \\
\hline & & & & & & & Cross section & None & 90 & 10 & Spots & $1 / 16$ \\
\hline $\mathrm{P}-45$ & Graphite & 4 & 1450 & 10,000 & \multicolumn{2}{|c|}{ None } & Edge & 0.001 & 60 & 40 & -- & -- \\
\hline$p-45-B$ & Graphite & 4 & 1450 & 10,000 & 5 & 1850 & Edge & 0.001 & 95 & 5 & -- & -- \\
\hline \multirow[t]{2}{*}{$P-47$} & Graphite & 4 & 1500 & 10,000 & 5 & 1850 & Edge & None & 95 & -- & 5 & - \\
\hline & & & & & & & Cross section & None & 60 & 10 & 30 & $1 / 8$ \\
\hline \multirow[t]{2}{*}{$P-52$} & Graphite & 4 & 1450 & 10,000 & 5 & 1850 & Edge & None & 90 & 5 & 5 & -- \\
\hline & & & & & & & Cross section & None & 80 & 10 & 10 & $1 / 8$ \\
\hline$P-58$ & Graphite & 4 & 1500 & 10,000 & 5 & 1850 & Cross section & None & 60 & -- & 40 & $1 / 16$ \\
\hline$P-58$ & Graphite & 4 & 1500 & 10,000 & 5 & 1850 & Cross section & None & 40 & 30 & 30 & $1 / 16$ \\
\hline
\end{tabular}




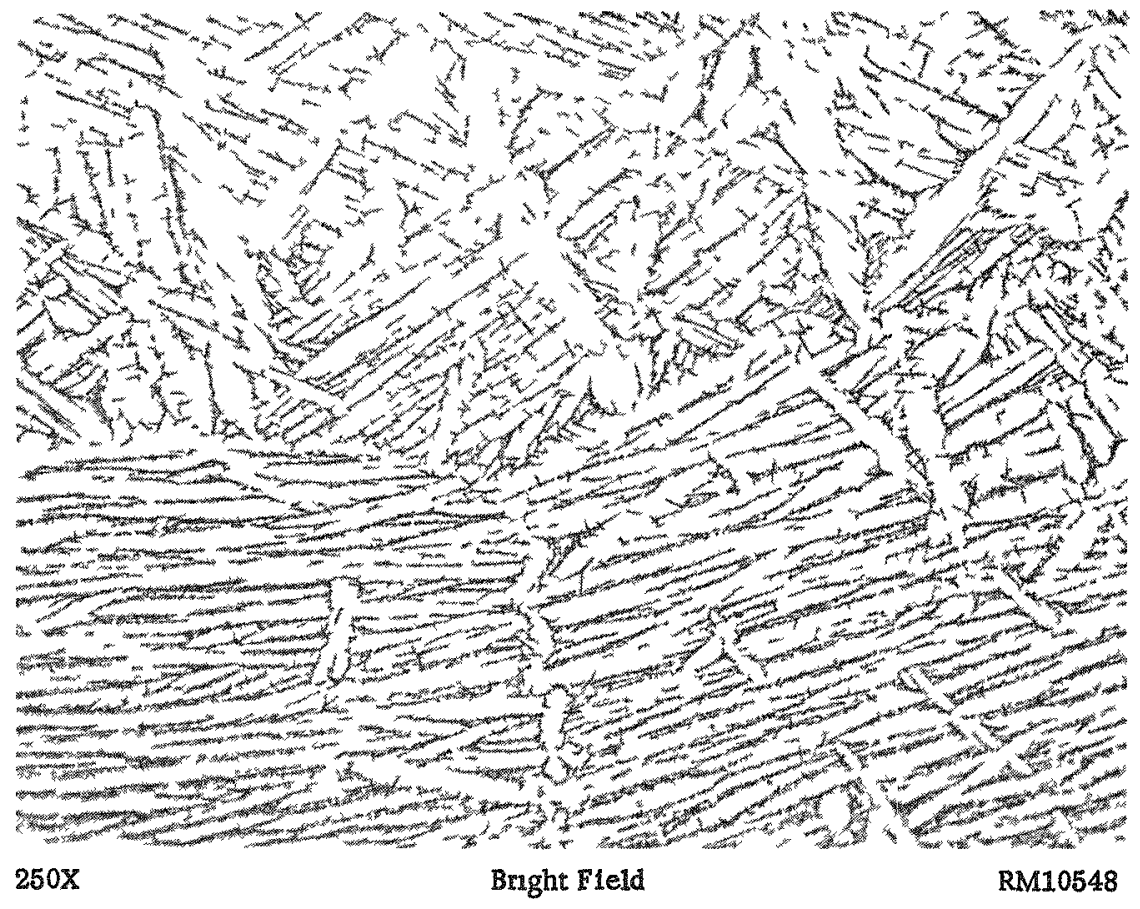

FIGURE, 25. ZIRCALOY-TO-ZIRCALOY BOND OBTAINED IN FUEL ELEMENT WHICH WAS PRESSURE BONDED AND BETA HEAT TREATED

This element was pressure bonded at $1550 \mathrm{~F}$ and $10,000 \mathrm{psi}$ for $4 \mathrm{hr}$ and heat treated at $1850 \mathrm{~F}$ for $5 \mathrm{~min}$. Beltmabraded bonding surfaces and graphitecoated cores were used. Bond is between the cladding $\mathrm{pl}$ ate and a rib of the picture frame.

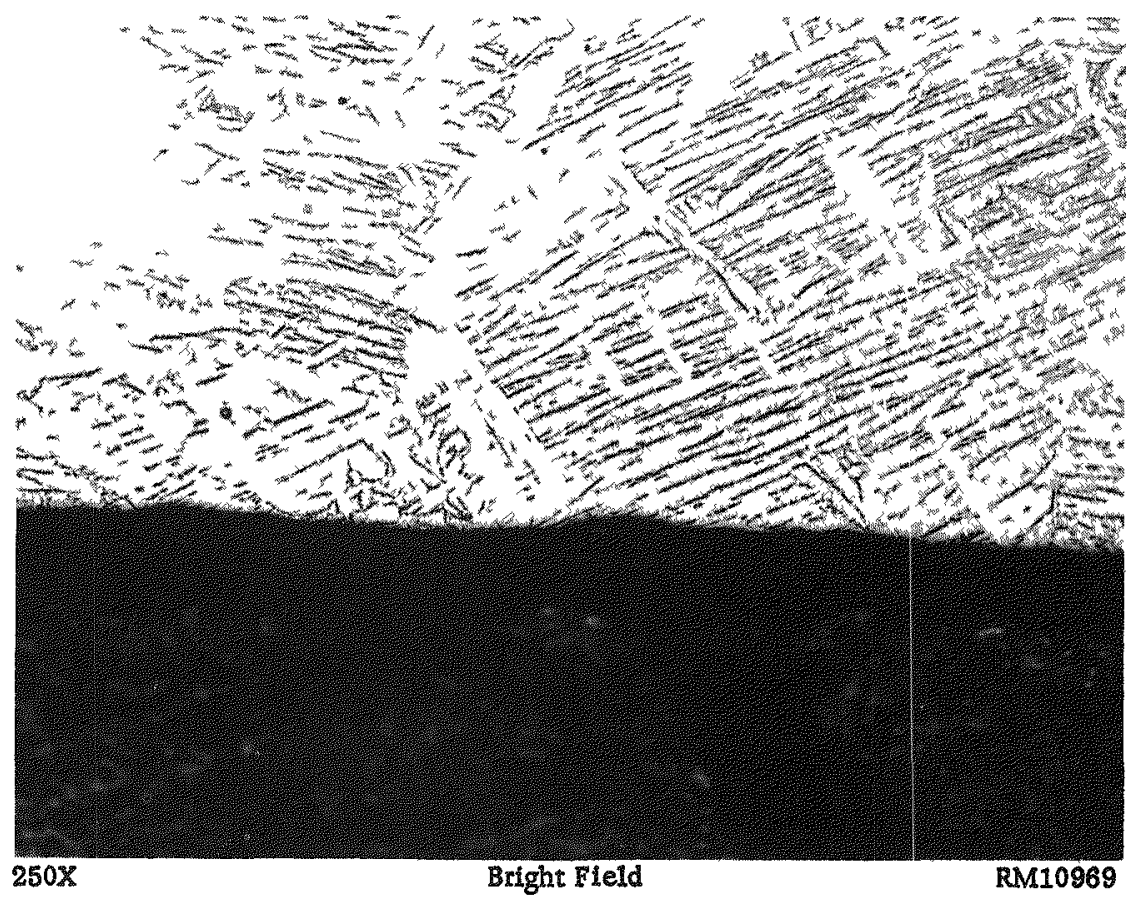

FIGURE 26. INTERF ACE BETWEEN GRAPHITE-COATED CORE AND ZIRCALOY CLADDING
Bond interface

Zircaloy-2

Graphite barrier layer

100 per cent $\mathrm{UO}_{2}$

Same specimen as shown in Figure 25. 
TABLE 14. RESULTS OF PEEL TESTS OE BONDS IN ZIRCALOY-CLAD FLAT-PLATE UO ${ }_{2}$ FUEL ELEMENTS

\begin{tabular}{|c|c|c|c|c|c|c|c|c|c|}
\hline \multirow{2}{*}{ Specimen } & \multirow{2}{*}{$\begin{array}{l}\text { Core } \\
\text { Coating }\end{array}$} & \multirow{2}{*}{\multicolumn{3}{|c|}{ Pressure-Bonding Conditions }} & \multirow{2}{*}{\multicolumn{2}{|c|}{ Heat Treatment }} & \multicolumn{3}{|c|}{ Peel-Test Results } \\
\hline & & & & & & & $\begin{array}{l}\text { Bond } \\
\text { Along } \\
\text { Ribs }\end{array}$ & $\begin{array}{l}\text { Bond Along Edges } \\
\text { (Excluding Edge- } \\
\text { Effect Zone) }\end{array}$ & $\begin{array}{l}\text { Depth of Edge } \\
\text { Effect, in. }\end{array}$ \\
\hline$P-5$ & Graphite & 1550 & 4 & 10,000 & 1850 & 5 & Good & Good & $1 / 8$ \\
\hline $\mathrm{P}-6$ & None & 1550 & 4 & 10,000 & 1850 & 5 & Good & Good & $1 / 32$ \\
\hline$P-9$ & None & 1550 & 4 & 10,000 & None & None & Good & Good & $1 / 16$ \\
\hline$P-10$ & None & 1550 & 4 & 10,000 & 1850 & 5 & Good & Good & None \\
\hline $\mathrm{P}-11$ & Graphite & 1550 & 4 & 10,000 & 1850 & 5 & Good & Good & None \\
\hline$P-47$ & Graphite & 1500 & 4 & 10,000 & 1850 & 5 & Good & Good & $1 / 8$ \\
\hline $\mathrm{P}-52$ & Graphite & 1450 & 4 & 10,000 & 1850 & 5 & Failed & Good & $1 / 16$ \\
\hline
\end{tabular}


A similar zone at the extreme ends of the elements was about $1 / 4 \mathrm{in.}$ wide. Except in this edge-effect region, the bond at the edge could not be separated in any of the specimens tested.

\section{Bend Tests}

A number of the pressure-bonded elements exhibited brittle failure of a portion of the cladding when the element was separated from the Ti-Namel spacers and the protective can after bonding. Many of the specimens exhibited both ductile and brittle cladding areas; consequently, investigations were conducted using bend tests of the cladding in conjunction with chemical analyses and metallographic observations to determine the causes of the inconsistent ductility of the cladding.

A tabulation of bend-test results is presented in Table 15. Results of bend-test specimens taken from cladding plates in the areas which failed during decanning showed that these areas were quite brittle, having an average $\mathrm{T}$-value of about 5 . The brittleness was not caused by core-cladding reaction, since the cladding from an element with the most severe reaction $(P-70)$ demonstrated very ductile behavior.

Portions of the cladding removed from areas adjacent to brittle fractures were subjected to metallographic examination. Results of these studies indicate that the se areas have a high concentration of hydride, as shown in Figure 27, or are high in iron. The thickness and integrity of the chromium plating applied to the Ti-Namel spacers to attempt to prevent diffusion of iron into the Zircaloy was not always suitable for this application and localized bonding occurred between the spacers and cladding. Figure 28 shows a section of ruptured cladding which reveals severe reaction between the cladding and spacers, and a structure heavily contaminated with hydrogen and iron.

Chemical analyses of these brittle elements showed hydrogen contents of 175 to $450 \mathrm{ppm}$. Oxygen contents were generally in the same range as in the as-received cover plate. This content was rather high (1320 ppm) but did not seem to affect the ductility of the cladding. A tabulation of chemical analyses is presented in Table 16 . The results indicate that chromium, nickel, nitrogen, and uranium did not contribute a significant amount to the brittleness of clad fuel elements.

A piece of brittle cladding, which was subjected to a solution heat treatment for hydrogen by heating at $750 \mathrm{~F}$ for $1 \mathrm{hr}$ followed by quenching, showed significantly improved ductility during bend testing. The beta heat treatment and quench employed after pressure bonding also improved the ductility of the cladding.

The results of the bend tests, chemical analyses, and metallographic examination indicated that the brittle behavior of the cladding during decanning was due primarily to high concentrations of hydrogen and iron. Stress applied in attempting to remove the spacers, which had bonded to the cladding in some areas, caused rupture of the embrittled cladding. In some cases, failure may have been aided by cracks in the brittle oxygen-rich zone of the Zircaloy surrounding the cores, which resulted from corecladding reaction. This latter effect will be discussed more fully in the next section on corrosion tests and core-cladding reaction. 
TABLE 15. RESULTS OF BEND TESTS OF ZIRCALOY-2 EROM PRESSURE-BONDED ELEMENTS

\begin{tabular}{|c|c|c|c|c|c|c|c|c|c|}
\hline \multirow[b]{2}{*}{ Specimen } & \multirow[b]{2}{*}{$\begin{array}{l}\text { Core } \\
\text { Coating }\end{array}$} & \multicolumn{3}{|c|}{ Pressure-Bonding Conditions } & \multicolumn{2}{|c|}{ Heat-T reatment } & \multirow[b]{2}{*}{$\begin{array}{l}\text { Location } \\
\text { of Sample }\end{array}$} & \multirow[b]{2}{*}{$\begin{array}{c}\text { Bend-Test } \\
\mathrm{T}-\mathrm{V} \text { alue }\end{array}$} & \multirow[b]{2}{*}{$\begin{array}{c}\text { Remarks Concerning } \\
\text { Element }\end{array}$} \\
\hline & & $\begin{array}{c}\text { Temperature, } \\
\mathrm{F}\end{array}$ & $\begin{array}{c}\text { Time, } \\
\text { hr }\end{array}$ & $\begin{array}{l}\text { Pressure, } \\
\text { psi }\end{array}$ & $\begin{array}{c}\text { Temperature, } \\
F\end{array}$ & $\begin{array}{l}\text { Time, } \\
\text { min }\end{array}$ & & & \\
\hline $\mathrm{P}-\mathrm{S}$ & - & - & - & - & - & - & $\begin{array}{l}\text { Cladding } \\
\text { plate }\end{array}$ & 0.67 & As-received material \\
\hline $\mathrm{P}-\mathrm{S}-1$ & $\cdots$ & - & -- & -- & $\begin{array}{l}1550 \\
\text { (in vacuum) }\end{array}$ & 240 & $\begin{array}{l}\text { Cladding } \\
\text { plate }\end{array}$ & 0.76 & As-received material \\
\hline$P-A-1$ & -- & 1550 & 4 & 10,000 & 1850 & 5 & End & 0.53 & Cladding plates \\
\hline$P-A-2$ & -. & 1550 & 4 & 10,000 & 1850 & 5 & Center & 0.71 & exposed directly to \\
\hline $\mathrm{P}-\mathrm{A}-3$ & -- & 1550 & 4 & 10,000 & 1850 & 5 & Edge & 0.53 & autoclave atmosphere \\
\hline$P-9-6$ & None & 1550 & 4 & 10,000 & None & & Edge & 3.18 & Burst at low pressure \\
\hline$P-9-A$ & None & 1550 & 4 & 10,000 & None & & $\begin{array}{l}\text { Cladding } \\
\text { plate over } \\
\text { core }\end{array}$ & 16.7 & during leak testing \\
\hline$P-9-7$ & None & 1550 & 4 & 10,000 & None & & $\begin{array}{l}\text { Cladding } \\
\text { plate over } \\
\text { core }\end{array}$ & 10.0 & \\
\hline$P-12-2$ & Graphite & 1500 & 4 & 10,000 & 1850 & 5 & Edge & 6.52 & Good burst test \\
\hline$P-12-3$ & Graphite & 1500 & 4 & 10,000 & 1850 & 5 & $\begin{array}{l}\text { Cladding } \\
\text { plate over } \\
\text { core }\end{array}$ & 6.57 & \\
\hline$P-1207$ & Graphite & 1500 & 4 & 10,000 & 1850 & 5 & End & 6.47 & \\
\hline$P-13-E$ & None & 1550 & 4 & 10,000 & None & & $\begin{array}{l}\text { End; away } \\
\text { from failure }\end{array}$ & 4.36 & $\begin{array}{l}\text { Brittle failure of } \\
\text { cladding plate } \\
\text { during decanning }\end{array}$ \\
\hline $\mathrm{P}-20-1$ & Graphite & 1550 & 4 & 10,000 & None & & $\begin{array}{l}\text { End; away } \\
\text { from cracks }\end{array}$ & 2.16 & $\begin{array}{l}\text { Burst at low pressure } \\
\text { in burst test; cracks } \\
\text { visible in cladding } \\
\text { plate }\end{array}$ \\
\hline$P-20-7$ & Graphite & 1550 & 4 & 10,000 & None & & $\begin{array}{l}\text { Cladding } \\
\text { plate over } \\
\text { core; by crac }\end{array}$ & 6.75 & \\
\hline$P-20-8$ & Graphite & 1550 & 4 & 10,000 & None & & $\begin{array}{l}\text { Cladding } \\
\text { plate over } \\
\text { core; away } \\
\text { from cracks }\end{array}$ & 3.26 & \\
\hline
\end{tabular}


TABLE 15. (Continued)

\begin{tabular}{|c|c|c|c|c|c|c|c|c|c|}
\hline \multirow[b]{2}{*}{ Specimen } & \multirow[b]{2}{*}{$\begin{array}{l}\text { Core } \\
\text { Coating }\end{array}$} & \multicolumn{3}{|c|}{ Pressure-Bonding Conditions } & \multicolumn{2}{|c|}{ Heat Treatment } & \multirow[b]{2}{*}{$\begin{array}{l}\text { Location } \\
\text { of Sample }\end{array}$} & \multirow[b]{2}{*}{$\begin{array}{l}\text { Bend-Test } \\
\text { T-Value }\end{array}$} & \multirow[b]{2}{*}{$\begin{array}{c}\text { Remarks Concerning } \\
\text { Element }\end{array}$} \\
\hline & & $\begin{array}{c}\text { Temperature, } \\
\text { F }\end{array}$ & Times & $\begin{array}{l}\text { Pressure, } \\
\text { psi }\end{array}$ & $\begin{array}{l}\text { Temperature, } \\
\text { F }\end{array}$ & $\begin{array}{c}\text { Time, } \\
\mathrm{hr}\end{array}$ & & & \\
\hline $\mathrm{P}-20-14$ & Graphite & 1550 & 4 & 10,000 & None & & $\begin{array}{l}\text { Cladding } \\
\text { plate over } \\
\text { core; by } \\
\text { burst rupture }\end{array}$ & 4.74 & \\
\hline$P=20-4 A$ & Graphite & 1550 & 4 & 10,000 & None & & $\begin{array}{l}\text { Cladding } \\
\text { plate over } \\
\text { core by crack }\end{array}$ & 5.20 & \\
\hline$P-20-4$ & Graphite & 1550 & 4 & 10,000 & $\begin{array}{l}750 \\
\text { (in vacuurn) }\end{array}$ & 60 & $\begin{array}{l}\text { Cladding } \\
\text { plate over } \\
\text { core by crack }\end{array}$ & 2.47 & \\
\hline $\mathrm{P}-21-\mathrm{E}$ & Graphite & 1550 & 4 & 10,000 & None & & End & 6.32 & Piece of cladding \\
\hline$P-21-2$ & Graphite & 1550 & 4 & 10,000 & None & & Edge & 3.10 & plate ruptured during \\
\hline $\mathrm{P}-21-4$ & Graphite & 1550 & 4 & 10,000 & None & & $\begin{array}{l}\text { Cladding plate } \\
\text { over core }\end{array}$ & 4.78 & decanning \\
\hline P-25-E & Graphite & 1525 & 4 & 10,000 & None & & End & 8.43 & Brittle failure of \\
\hline$p-25-2$ & Graphite & 1525 & 4 & 10,000 & None & & $\begin{array}{l}\text { Cladding plate } \\
\text { over core }\end{array}$ & 4.14 & $\begin{array}{l}\text { cladding plate during } \\
\text { decanning }\end{array}$ \\
\hline$P-25-3$ & Graphite & 1525 & 4 & 10,000 & None & & $\begin{array}{l}\text { Cladding plate } \\
\text { over core }\end{array}$ & 5.78 & \\
\hline$P-45-1$ & Graphite & 1450 & 4 & 10,000 & 1850 & 5 & End & 0.61 & Good burst test \\
\hline$P-45-3$ & Graphite & 1450 & 4 & 10,000 & 1850 & 5 & $\begin{array}{l}\text { Cladding plate } \\
\text { over core }\end{array}$ & 0.84 & \\
\hline$P-52-4$ & Graphite & 1450 & 4 & 10,000 & 1850 & 5 & Edge & 2.23 & Intercompartmental \\
\hline$P-52-8$ & Graphite & 1450 & 4 & 10,000 & 1850 & 5 & End & 1.07 & leakage \\
\hline$P-52-9$ & Graphite & 1450 & 4 & 10,000 & 1850 & 5 & $\begin{array}{l}\text { Cladding plate } \\
\text { over core }\end{array}$ & 0.97 & \\
\hline$P-57-E$ & Graphite & 1500 & 4 & 10,000 & None & & End & 4.39 & Burst-test leakage \\
\hline P-58-E & Graphite & 1500 & 4 & 10,000 & 1850 & 5 & End & 1.10 & Burst-test leakage \\
\hline P-58-A & Graphite & 1500 & 4 & 10,000 & 1850 & 5 & $\begin{array}{l}\text { Cladding plate } \\
\text { over core }\end{array}$ & 0.99 & \\
\hline
\end{tabular}


TABLE 15. (Continued)

\begin{tabular}{|c|c|c|c|c|c|c|c|c|c|}
\hline \multirow[b]{2}{*}{ Specimen } & \multirow[b]{2}{*}{$\begin{array}{l}\text { Core } \\
\text { Coating }\end{array}$} & \multicolumn{3}{|c|}{ Pressure-Bonding Conditions } & \multicolumn{2}{|c|}{ Heat Treatment } & \multirow[b]{2}{*}{$\begin{array}{l}\text { Location } \\
\text { of Sample }\end{array}$} & \multirow[b]{2}{*}{$\begin{array}{l}\text { Bend-Test } \\
T \text {-Value }\end{array}$} & \multirow[b]{2}{*}{$\begin{array}{c}\text { Remarks Concerning } \\
\text { Element }\end{array}$} \\
\hline & & $\begin{array}{c}\text { Temperature, } \\
F\end{array}$ & $\begin{array}{c}\text { Time, } \\
\text { hr }\end{array}$ & $\begin{array}{l}\text { Pressure, } \\
\text { psi }\end{array}$ & $\begin{array}{c}\text { Temperature, } \\
\text { F }\end{array}$ & $\underset{\mathrm{hr}}{\mathrm{Time}}$ & & & \\
\hline$P-61-E$ & Graphite & 1550 & 4 & 10,000 & Nor & & & 8.3 & $\begin{array}{l}\text { Brittle failure of } \\
\text { cladding plate during } \\
\text { decanning }\end{array}$ \\
\hline$P-63-1$ & Graphite & 1500 & 4 & 10,000 & Nor & & $\begin{array}{l}\text { Cladding plate } \\
\text { at edge }\end{array}$ & 0.69 & $\begin{array}{l}\text { Can failure during } \\
\text { bonding }\end{array}$ \\
\hline$p-63-2$ & Graphite & 1500 & 4 & 10,000 & Nor & & $\begin{array}{l}\text { Cladding plate } \\
\text { over core }\end{array}$ & 1.52 & \\
\hline$P-63-3$ & Graphite & 1500 & 4 & 10,000 & Nor & & Edge & 0.13 & \\
\hline $\mathrm{P}-67-\mathrm{R}$ & Graphite & 1500 & 4 & 10,000 & Nor & & $\mathrm{Rib}$ & 0.44 & Brittle failure of \\
\hline$P-67-2$ & Graphite & 1500 & 4 & 10,000 & Nor & & $\begin{array}{l}\text { Cladding plate } \\
\text { over core; away } \\
\text { from fracture }\end{array}$ & 1.00 & $\begin{array}{l}\text { cladding plate during } \\
\text { decanning }\end{array}$ \\
\hline$P-67-5$ & Graphite & 1500 & 4 & 10,000 & Nor & & $\begin{array}{l}\text { Edge; away from } \\
\text { fracture }\end{array}$ & 2.14 & \\
\hline$P-67-8$ & Graphite & 1500 & 4 & 10,000 & Nor & & $\begin{array}{l}\text { End; away from } \\
\text { fracture }\end{array}$ & 2.09 & \\
\hline P-67-10 & Graphite & 1500 & 4 & 10,000 & Nor & & $\begin{array}{l}\text { Cladding plate } \\
\text { over core; near } \\
\text { fracture }\end{array}$ & 5.68 & \\
\hline$P-67-14$ & Graphite & 1500 & 4 & 10,000 & Nor & & $\begin{array}{l}\text { Edge; near } \\
\text { fracture }\end{array}$ & 3.15 & \\
\hline$P-70-1$ & None & 1550 & 4 & 10,000 & 1850 & 5 & $\begin{array}{l}\text { Cladding plate } \\
\text { over core }\end{array}$ & 0.75 & $\begin{array}{l}\text { Severe core-cladding } \\
\text { reaction }\end{array}$ \\
\hline P-71-C & Graphite & 1450 & 4 & 10,000 & 1850 & 5 & $\begin{array}{l}\text { Cladding plate } \\
\text { over core }\end{array}$ & 2.46 & $\begin{array}{l}\text { Stainless steel shims } \\
\text { between cladding } \\
\text { plates and Ti-Namel } \\
\text { spacers }\end{array}$ \\
\hline$P-73-E$ & Graphite & 1450 & 4 & 10,000 & 1850 & 5 & End & 1.61 & $\begin{array}{l}\text { Stainless steel shims } \\
\text { between cladding } \\
\text { plates and Ti-Namel } \\
\text { spacers }\end{array}$ \\
\hline
\end{tabular}


TABLE 16. CHEMICAL ANALYSES OF ZIRCALOY CLADDING REMOVED

\begin{tabular}{|c|c|c|c|c|c|c|c|}
\hline \multirow[b]{2}{*}{ Specimen } & \multirow[b]{2}{*}{ Core Coatıng } & \multicolumn{3}{|c|}{ Pressure-Bonding Conditions } & \multicolumn{2}{|c|}{ Heat Treatment } & \multirow[b]{2}{*}{ Location } \\
\hline & & $\begin{array}{c}\text { Temperature, } \\
F\end{array}$ & $\begin{array}{c}\text { Time, } \\
\mathrm{hr}\end{array}$ & $\begin{array}{c}\text { Pressure, } \\
\text { ps1 }\end{array}$ & $\begin{array}{c}\text { Temperature, } \\
F\end{array}$ & $\begin{array}{l}\text { Time, } \\
\text { min }\end{array}$ & \\
\hline $\mathrm{P}-\mathrm{S}$ & - & $m$ & - & $-\infty$ & $\cdots$ & - & Claddung plate \\
\hline$P-S-1$ & $-\infty$ & -- & $=$ & $=$ & $\begin{array}{l}1550 \\
\quad \text { (in vact }\end{array}$ & 240 & Cladding plate \\
\hline$P-9 \propto 7$ & None & 1550 & 4 & 10,000 & Non & & $\begin{array}{l}\text { Cladding plate } \\
\text { over core }\end{array}$ \\
\hline$P-10-1$ & None & 1550 & 4 & 10,000 & Non & & End \\
\hline$p-10-2$ & None & 1550 & 4 & 10,000 & Non & & $\begin{array}{l}\text { Cladding plate } \\
\text { over core }\end{array}$ \\
\hline$P-20=7$ & Graphite & 1550 & 4 & 10,000 & Non & & Cladding plate \\
\hline$P-21-1$ & Graphite & 1550 & 4 & 10,000 & Non & & End \\
\hline $\mathrm{P}-25-1$ & Graphite & 1525 & 4 & 10,000 & Non & & End \\
\hline$P \sim 27 m 1$ & Graphite & 1525 & 4 & 10,000 & Non & & End \\
\hline $\mathrm{P}-\mathrm{A} 1$ & -- & 1550 & 4 & 10,000 & 1850 & 5 & End \\
\hline P $\sim \mathrm{A} 2$ & $\infty$ & 1550 & 4 & 10,000 & 1850 & 5 & Center \\
\hline$P=45-3$ & Graphite & 1450 & 4 & 10,000 & 1850 & 5 & $\begin{array}{l}\text { Claddung plate } \\
\text { over core }\end{array}$ \\
\hline$P-52 m 8$ & Graphite & 1450 & 4 & 10,000 & 1850 & 5 & End \\
\hline$P=52-9$ & Graphite & 1450 & 4 & 10,000 & 1850 & 5 & $\begin{array}{l}\text { Cladding plate } \\
\text { over core }\end{array}$ \\
\hline$P-63-1$ & Graphite & 1500 & 4 & 10,000 & Non & & $\begin{array}{l}\text { Cladding plate } \\
\text { at edge }\end{array}$ \\
\hline$P \sim 63-2$ & Graphite & 1500 & 4 & 10,000 & Non & & $\begin{array}{l}\text { Cladding plate } \\
\text { over core }\end{array}$ \\
\hline$P-67 m 2$ & Graphite & 1500 & 4 & 10,000 & Non & & $\begin{array}{r}\text { Cladding plate } \\
\text { (ductule area) }\end{array}$ \\
\hline $\mathrm{P}-67-10$ & Graphute & 1500 & 4 & 10,000 & Non & & $\begin{array}{c}\text { Cladding plate } \\
\text { (brittle area) }\end{array}$ \\
\hline$P-73-1$ & Graphite & 1450 & 4 & 10,000 & 1850 & 5 & End \\
\hline$P=73-2$ & Graphite & 1450 & 4 & 10,000 & 1850 & 5 & $\begin{array}{l}\text { Cladding plate } \\
\text { over core }\end{array}$ \\
\hline
\end{tabular}


FROM ELEMENTS PRESSURE BONDED IN CONTAINERS

\begin{tabular}{|c|c|c|c|c|c|c|c|c|}
\hline \multicolumn{8}{|c|}{ Analyses of Cladding } & \multirow{3}{*}{$\begin{array}{c}\text { Remarks Concerning } \\
\text { Element }\end{array}$} \\
\hline \multicolumn{2}{|c|}{$\begin{array}{l}\text { Vacuum Fusion, } \\
\text { ppm }\end{array}$} & \multicolumn{4}{|c|}{ Spectrographic, w/o } & \multirow{2}{*}{$\begin{array}{l}\text { Fluorescent } \\
\text { for } U, w / o\end{array}$} & \multirow{2}{*}{$\begin{array}{l}\text { Kjeldahl } \\
\text { for } N_{0}, w / o\end{array}$} & \\
\hline 0 & $\mathrm{H}$ & $\mathrm{Fe}$ & $\mathrm{Cr}$ & $\mathbf{U}$ & $\mathrm{Ni}$ & & & \\
\hline 1320 & 24 & 0.09 & 0.09 & ND & $<0.1$ & $<0.002$ & 0.003 & As-received material \\
\hline$-\infty$ & - & 0.08 & 0.09 & ND & $<0.1$ & $\cdots$ & $-\infty$ & As-received material \\
\hline$\ldots$ & - & 1.1 & 0.09 & 1 & $<0.1$ & 1.2 & 0.003 & $\begin{array}{l}\text { Burst at low pressure } \\
\text { during leak test }\end{array}$ \\
\hline 1370 & 106 & $m$ & -- & $\cdots$ & $\cdots$ & -- & 0.003 & Ductile behavior \\
\hline$\infty$ & $\cdots$ & $=$ & $\cdots$ & 0.5 & $-\infty$ & 0.51 & - & Same as above \\
\hline 1290 & 300 & 0.48 & 0.09 & - & -- & $\cdots$ & 0.003 & $\begin{array}{l}\text { Leakage; burst at low } \\
\text { pressure and showed } \\
\text { cracks in the clad- } \\
\text { ding }\end{array}$ \\
\hline 1260 & 231 & 0.09 & 0.08 & ND & $<0.1$ & $\infty$ & 0.004 & $\begin{array}{l}\text { Small portion of } \\
\text { cladding plate rup- } \\
\text { tured in decanning }\end{array}$ \\
\hline 1230 & 450 & 0.17 & 0.09 & ND & $<0.1$ & 0.002 & 0.006 & $\begin{array}{l}\text { Brittle failure of } \\
\text { cladding plate } \\
\text { during decanning }\end{array}$ \\
\hline 1160 & 304 & $\ldots$ & $-\infty$ & $\infty$ & $-\infty$ & $\cdots$ & $-\infty$ & $\begin{array}{l}\text { Brittle failure of } \\
\text { cladding during } \\
\text { decanning }\end{array}$ \\
\hline 1230 & 130 & 0.09 & 0.09 & ND & $<0.1$ & $\cdots$ & 0.005 & $\begin{array}{l}\text { Cladding plates ex } \\
\text { posed directly to } \\
\text { autoclave atmos= } \\
\text { phere }\end{array}$ \\
\hline$\cdots$ & 91 & $\cdots$ & -- & $\infty$ & 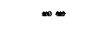 & $=$ & $\cdots$ & Same as above \\
\hline 1240 & 204 & 0.10 & 0.09 & $\cdots$ & -- & - & $-\infty$ & Fair burst test \\
\hline-- & 192 & 0.10 & 0.009 & ND & $<0.1$ & $m$ & 0.004 & $\begin{array}{l}\text { Leakage; ductile } \\
\text { cladding observed }\end{array}$ \\
\hline 1690 & 172 & 0.12 & 0.09 & $\mathrm{ND}$ & $<0.1$ & 0.002 & 0.003 & Same as above \\
\hline 1160 & 115 & 0.09 & 0.09 & -- & $-\infty$ & $\cdots$ & $\cdots$ & $\begin{array}{l}\text { Can failure during } \\
\text { bonding }\end{array}$ \\
\hline 1040 & 109 & 0.09 & 0.09 & $\cdots$ & -- & $\cdots$ & -- & Same as above \\
\hline 1320 & 79 & 0.19 & 0.09 & ND & $<0.1$ & $\infty$ & $-\infty$ & $\begin{array}{l}\text { Brittle failure of } \\
\text { cladding plate } \\
\text { during decanning }\end{array}$ \\
\hline 1420 & 175 & 0.39 & 0.07 & ND & $<0.1$ & 0.003 & 0.003 & Same as above \\
\hline 1720 & 143 & 0.09 & 0.09 & ND & $<0.1$ & $\cdots$ & 0.004 & $\begin{array}{l}\text { Stainless steel shims } \\
\text { between cladding } \\
\text { plates and spacers }\end{array}$ \\
\hline 1930 & 292 & $-\infty$ & $-\infty$ & $=$ & - & $\cdots$ & $-\infty$ & Same as above \\
\hline
\end{tabular}




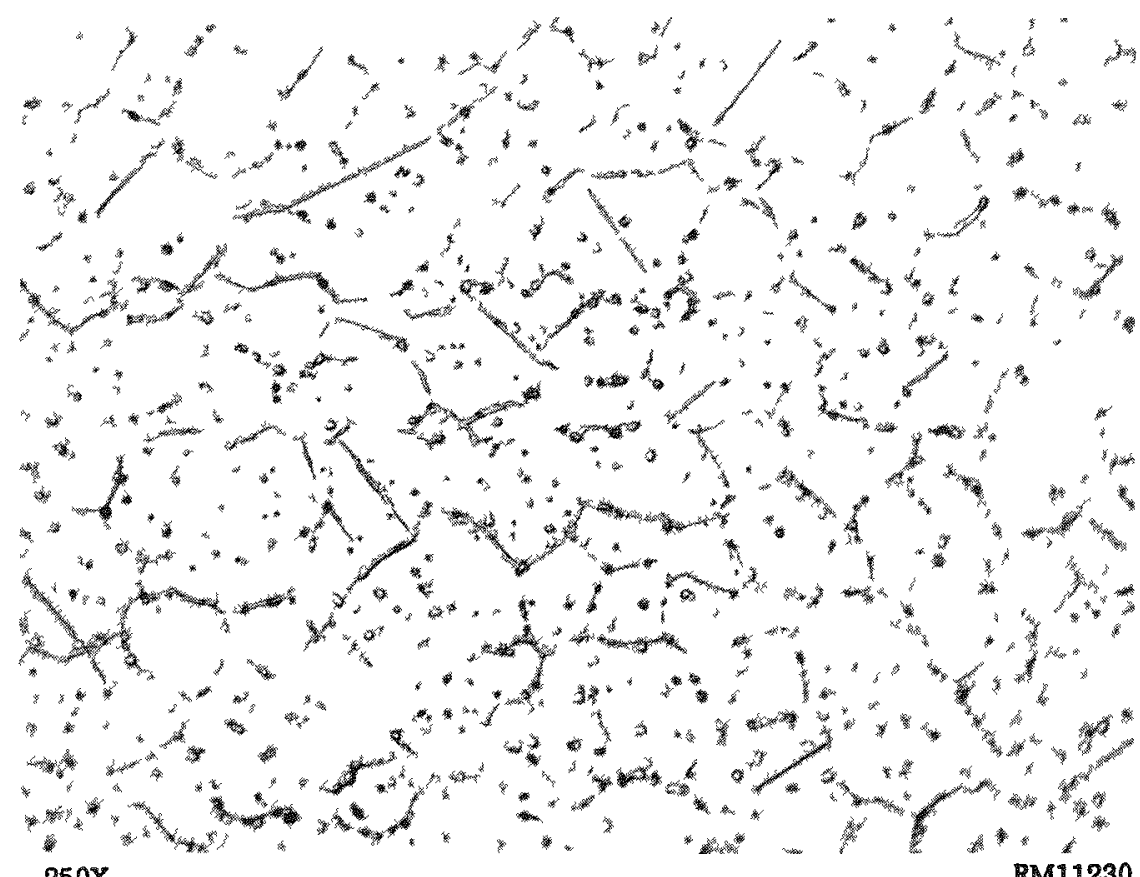

FIGURE 27. MICROSTRUCTURE OF ZIRCALOY SHOWING HIGH HYDROGEN CONTENT IN AN ELEMENT WHICH FAILED IN A BRITTLE FASHION DURING DECANNING

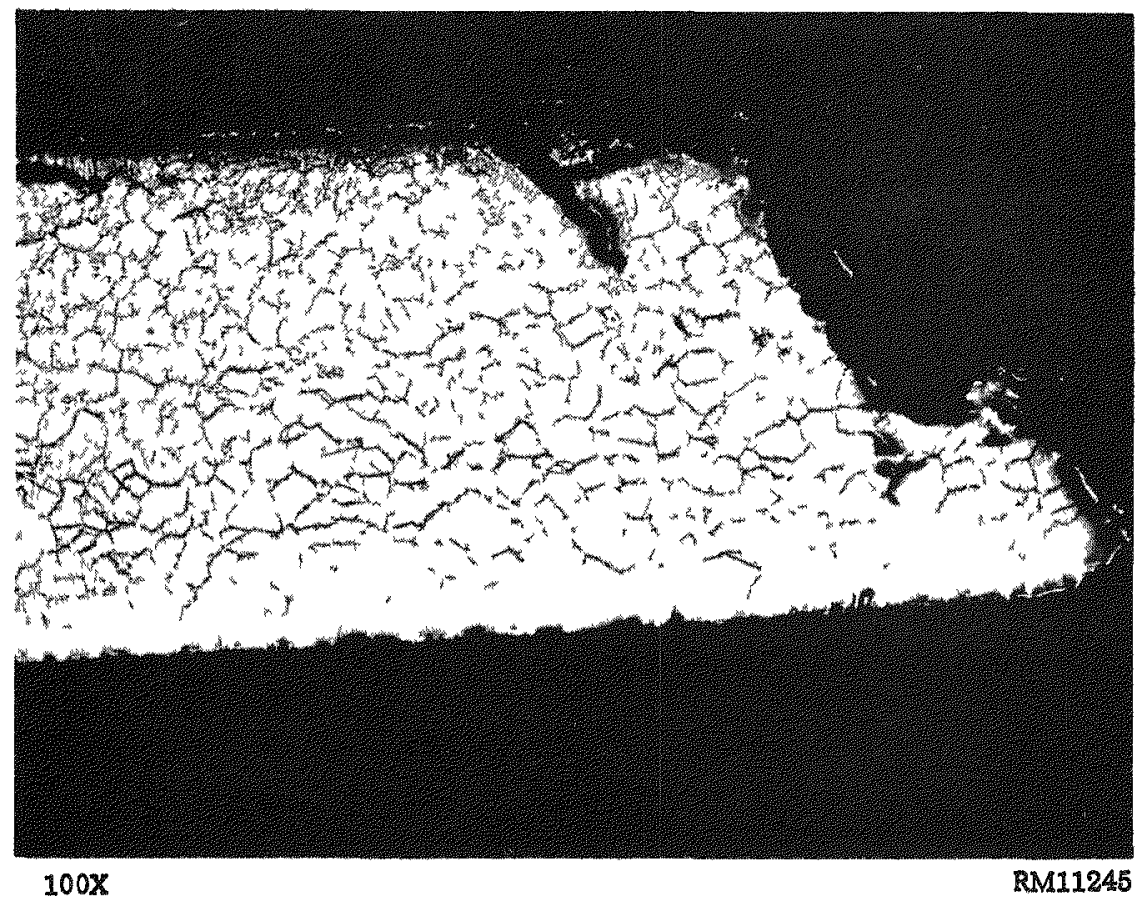

FIGURE 28. PORTION OF CLADDING PLATE FROM AN ELEMENT WHICH FAILED IN A BRTTTLE FASHION DURING DECANNING

Evidence of contammation by iron and hydrogen can be seen. (Top side of cladding plate was next to spacer; bottom was next to core.) 
The hydrogen contamination and iron were apparently introduced principally from the chromium-plated Ti-Namel spacers. The hydrogen did not appear to originate from the autoclave gas since chemical analyses of the Zircaloy from cladding plates exposed directly to autoclave gas during bonding showed the hydrogen content to be lower than in any of the elements bonded in containers Also, this cladding behaved in a very ductile fashion in bend tests, as is evidenced in Specimen P-A in Table 15. Several elements bonded with stainless steel shimming plates between the cladding plates and spacers revealed very little diffusion of iron into the Zircaloy and improved cladding ductility. However, these spacers had previously been chromium plated and the cladding of the elements contained a fairly high amount of hydrogen. It appears, therefore, that cladding embrittlement would not be a problem in elements pressure bonded in containers if the integrity of the chromium plate were improved and the hydrogen removed from the plated spacers prior to assembly, or if stainless steel shims were placed between the cladding plates and uncoated spacers.

Corrosion Tests of Purposely Defected Components

The results of $680 \mathrm{~F}$ water corrosion tests on elements with intentionally defected compartments are presented in Table 17 for short-time tests of 7 days. Additional results of corrosion tests of purposely defected compartments are contained in Table 19 in conjunction with results of intercompartmental-leakage tests. Fuel elements containing bare cores exhibited over-all thickness increases ranging from 0.003 to 0.017 in. due to localized bulging at the compartment end farthest away from the defect hole. Fuel elements containing graphite-coated cores did not bulge in 4 to 11 -day tests in $680 \mathrm{~F}$ water. Figure 29 shows one of the elements with graphite-coated cores which was pressure bonded and beta heat treated and exhibited no growth during corrosion testing. All elements gained from 0.2 to $1.6 \mathrm{~g}$ during corrosion testing, indicating the possibility of waterlogging or corrosion attack.

Although elements containing graphite-coated cores showed no swelling in shorttime corrosion tests, metallographic examination of sections of these elements revealed that the Neolube coating did not completely prevent core-cladding reaction. An oxygen-rich zone was observed around the circumference of the cores. These zones were found in elements with and without graphite barriers, although the extent of the zone was much greater in the latter, of course. Figure 30 shows such an area in a a specimen with a graphite barrier. Since the metallographic observations were not indicative of the results expected with graphite-coated cores, it was necessary to completely evaluate these specimens for core-cladding reaction.

The graphite coatings were applied by brushing graphite onto the core in the form of Neolube. The resultant coated cores were outgassed in a vacuum furnace at $750 \mathrm{~F}$. The extent of reaction of cores prepared in this manner with the Zircaloy cladding during bonding and heat treating was studied metallographically, by chemical analysis, and by microhardness measurements of the reaction zones.

The graphite coatings applied by brushing Neolube and outgassing were not sufficiently adherent and spalled due to a number of conditions. Particles of graphite, as well as $\mathrm{UO}_{2}$, were apparently flaked off during handling of the elements before pressure bonding. Graphite may also have flaked off during heating in the autoclave to $1550 \mathrm{~F}$ if intimate contact of the components was not obtained at low temperatures. Core coatings 
TABLE 17. RESULTS OF CORROSION TESTS IN $680 \mathrm{~F}$ WATER OF PRESSURE-BONDED FUEL ELEMENTS WITH INTENTIONALLY DEFECTED COMPARTMENTS

\begin{tabular}{|c|c|c|c|c|c|c|c|c|c|}
\hline \multirow[b]{2}{*}{ Specimen } & \multicolumn{3}{|c|}{ PressuremBonding Conditions } & \multirow[b]{2}{*}{$\begin{array}{l}\text { Core } \\
\text { Coating }\end{array}$} & \multicolumn{2}{|c|}{ Heat Treatment } & \multirow[b]{2}{*}{$\begin{array}{l}\text { Exposure Time, } \\
\text { days }\end{array}$} & \multirow[b]{2}{*}{$\begin{array}{l}\text { Thickness Increase } \\
\text { From Corrosion, mils }\end{array}$} & \multirow[b]{2}{*}{ Remarks } \\
\hline & $\begin{array}{c}\text { Temperature, } \\
F\end{array}$ & $\begin{array}{c}\text { Time, } \\
\text { hr }\end{array}$ & $\begin{array}{l}\text { Pressure, } \\
\text { psi }\end{array}$ & & $\begin{array}{c}\text { Temperature, } \\
\text { F }\end{array}$ & $\begin{array}{l}\text { Time, } \\
\text { min }\end{array}$ & & & \\
\hline$p-3$ & 1550 & 4 & 10,000 & None & 1850 & 5 & 7 & $10-15$ & $\begin{array}{l}\text { Slight bulging of } \\
\text { compartments at } \\
\text { ends opposite defects }\end{array}$ \\
\hline$P-49$ & 1550 & 4 & 10,000 & None & 1850 & 5 & 7 & $9-12$ & $\begin{array}{l}\text { Slight bulging of } \\
\text { compartments at } \\
\text { ends opposite defects }\end{array}$ \\
\hline $\mathrm{P}-17$ & 1550 & 4 & 10,000 & Graphite & 1850 & 5 & 7 & None & No apparent attack \\
\hline$P-53$ & 1450 & 4 & 10,000 & Graphite & 1850 & 5 & 7 & None & No apparent attack \\
\hline
\end{tabular}




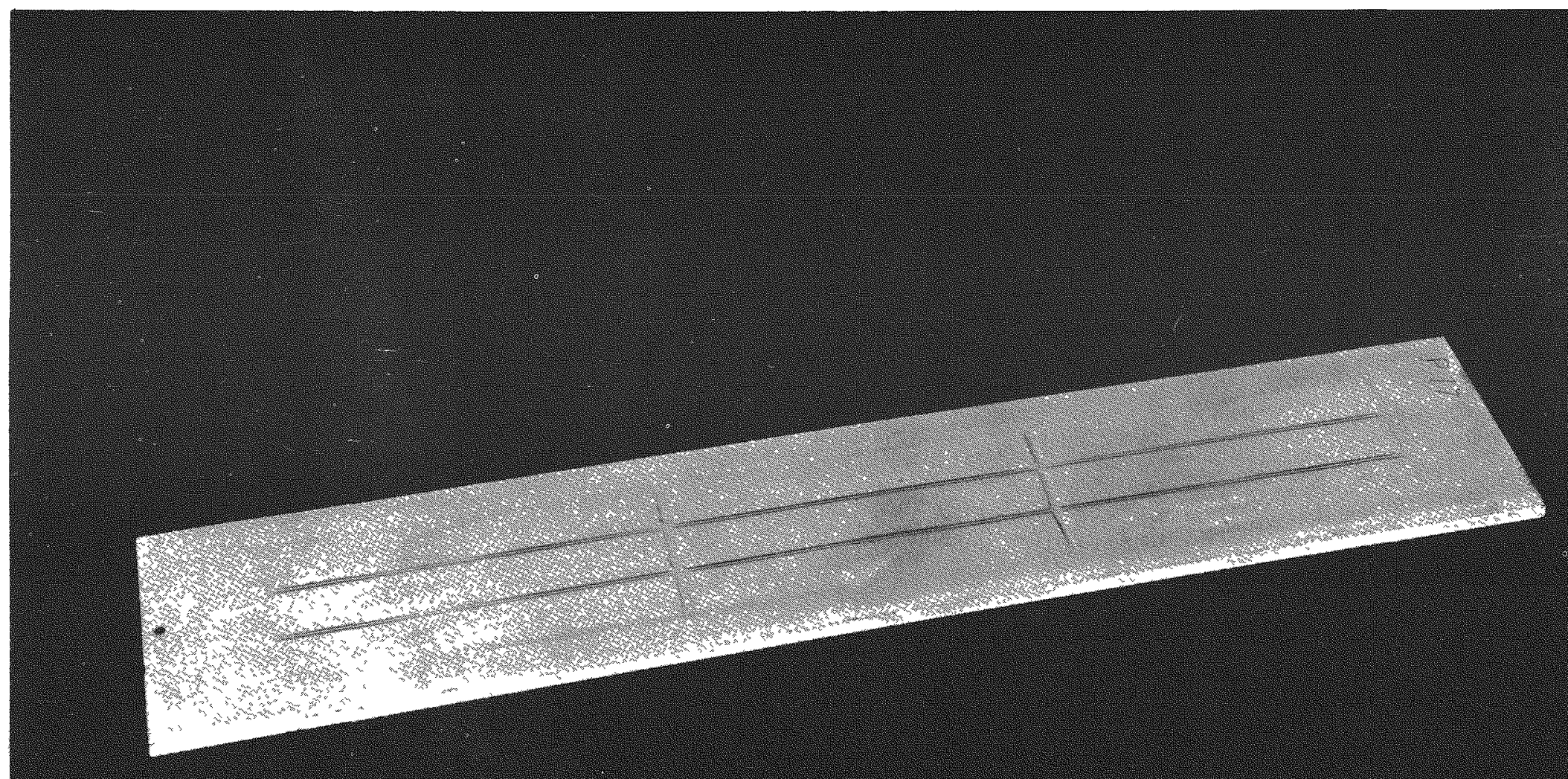

FIGURE 29. PRESSURE-BONDED AND HEAT-TREATED FUEL ELEMENT WITH PURPOSELY DEFECTED COMPARTMENTS CONT AINING GRAPHTTE-COATED CORES THAT SHOWED NO SWELLING DURING CORROSION TESTING

This element was pressure bonded at $1550 \mathrm{~F}$ and $10,000 \mathrm{psi}$ for $4 \mathrm{hr}$ and heat treated at $1850 \mathrm{~F}$ for 5 min in a salt bath. Compartments were defected with 0.005 -in. holes. Corrosion testing was for 7 days in $680 \mathrm{~F}$ water. 
which were adherent after heating in vacuum at $750 \mathrm{~F}$ have been observed to spall when similarly heated to $1550 \mathrm{~F}$. Particles of $\mathrm{UO}_{2}$ have also been observed to be blown off during such a cycle. The graphite coatings along with particles of $\mathrm{UO}_{2}$ were also removed at the corners of cores where excessive flow of the cladding occurred to accommodate undersize ribs present in all of the pressure-bonded elements. In addition to core-cladding reaction, the removal of the graphite and $\mathrm{UO}_{2}$ from core corners was accompanied by transport of these contaminants along the interfaces between the $\mathrm{r} 1 \mathrm{bs}$ and cladding plates, which resulted in poor bonding and intercompartmental leakage. Figure 30 shows such contamination extending from the corner of a core. The most extensive reaction and contamination were observed in elements with the greatest amount of cladding deformation. This condition as discussed further in connection with intercompartmental leakage.

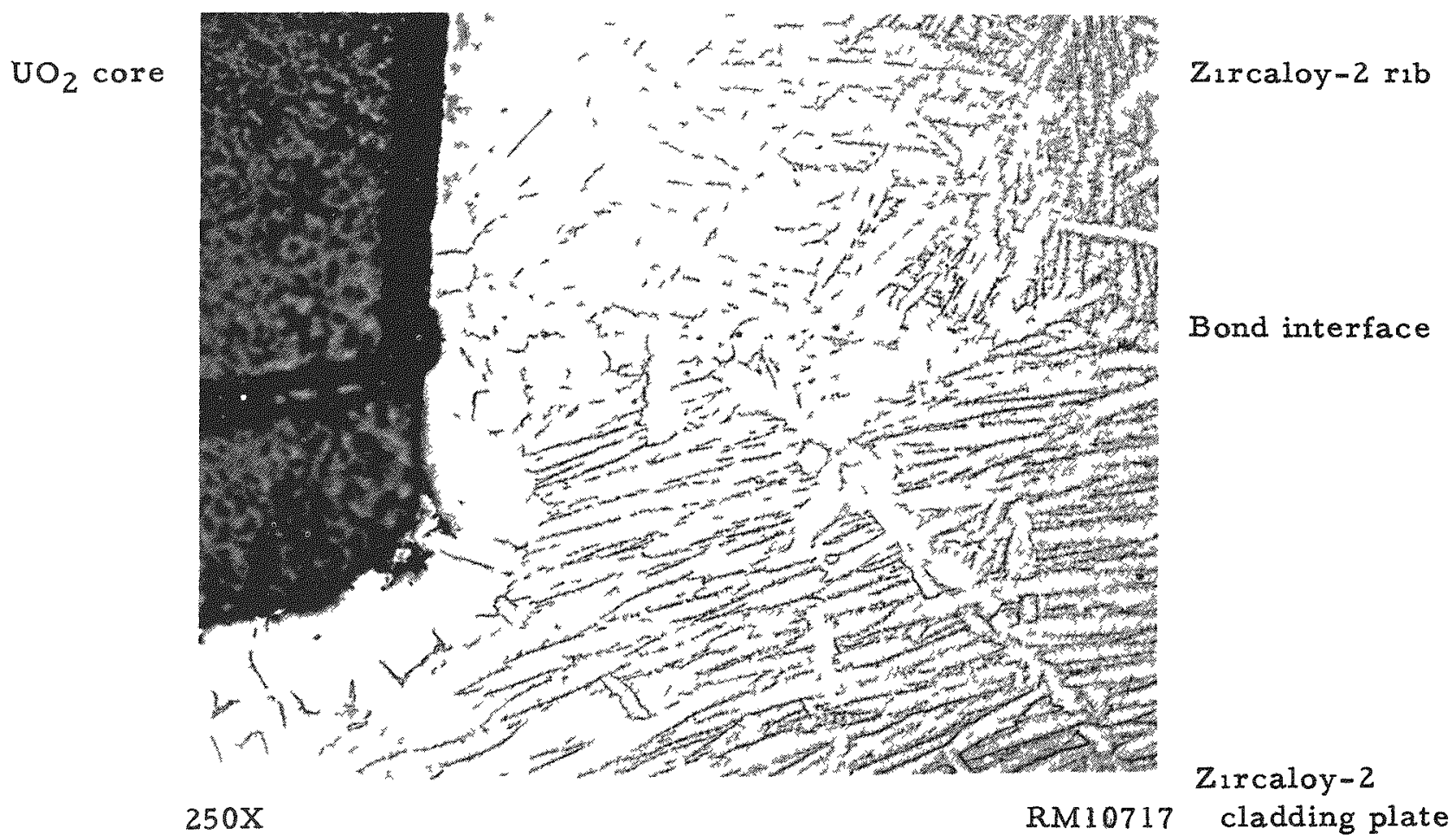

FIGURE 30. CORE-CLADDING REACTION AT CORNER OF GRAPHITE-COATED UO 2 CORE

Note apparent $\mathrm{UO}_{2}$ along bond line.

Microhardness studies revealed that the oxygen-rich zones adjacent to the cores were extremely hard. Figure 31 is a photomicrograph of one of the specimens tested showing the location and values of Knoop hardness tests. It is readily seen that the oxygen-rich zones at the corners of the cores possessed much higher hardnesses than the Zircaloy away from these zones. This hard zone contains cracks, as shown in Figures 32 and 33 , which may be a point of instiation of cladding failure during burst testing, as discussed later.

Chemical analyses of the cladding over cores indicated that uranium was present in all specumens. However, those elements which contained coated cores showed a 


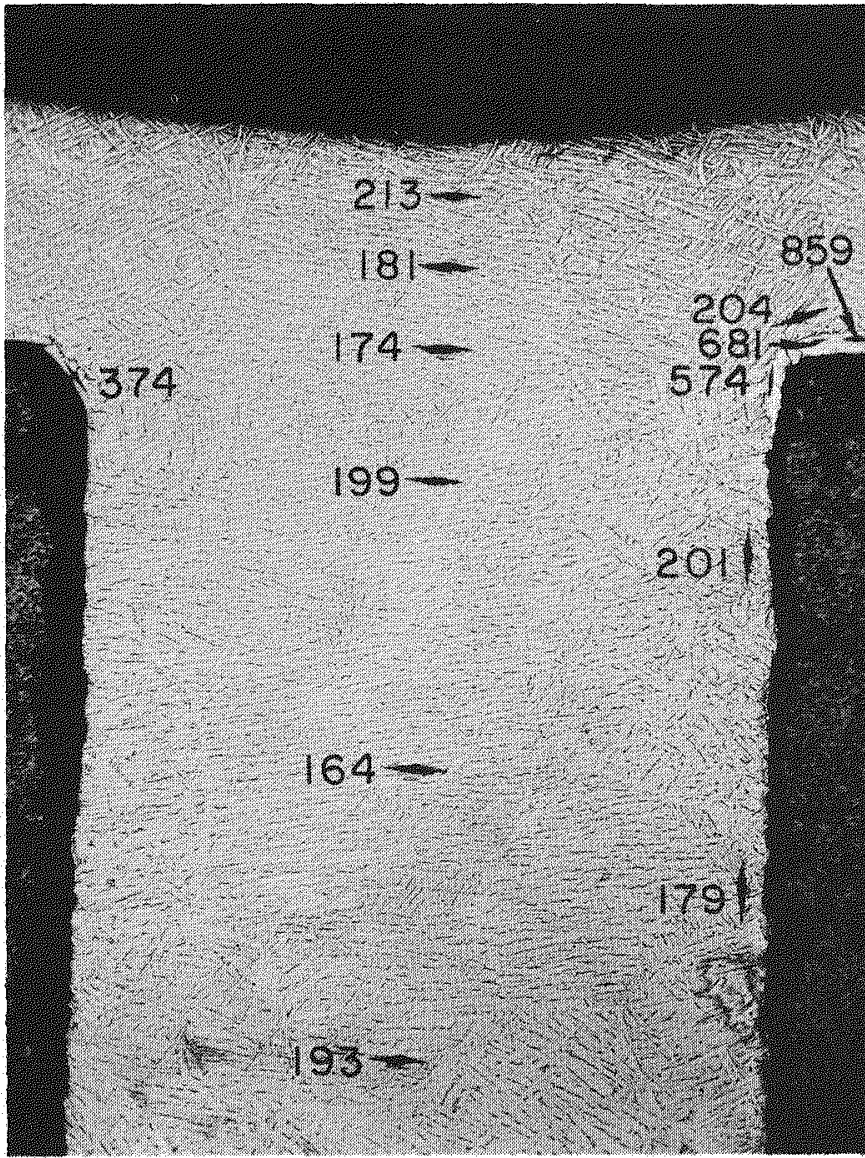

Zircaloy 2 cladding plate

$75 x$

Zircaloy $2 \mathrm{rib}$

N53379

$\mathrm{UO}_{2}$ core

FIGURE 31. KNOOP HARONESS VALUES AT RIB OF ELEMENT CONTAINING GRAPHITE-COATED CORES Note high hardness of oxygen-rich zone at corners of cores. 


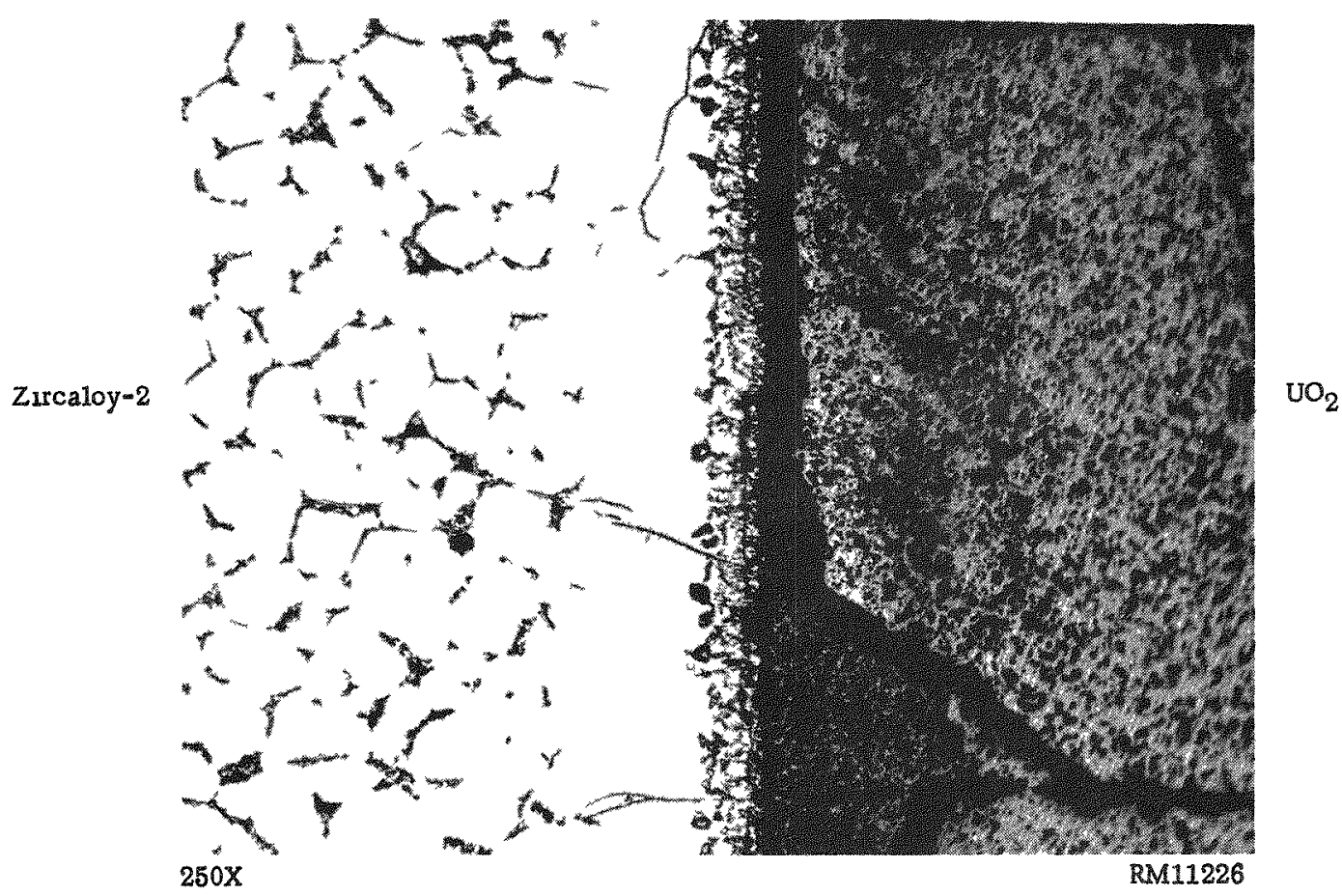

FIGURE 32. CRACKS IN BRITTLE OXYGEN-RICH ZONE OF ZIRCALOY AT CORE-CLADDING INTERF ACE OF PRESSURE-BONDED ELEMENT CONTAINING UNCOATED UO 2 CORES

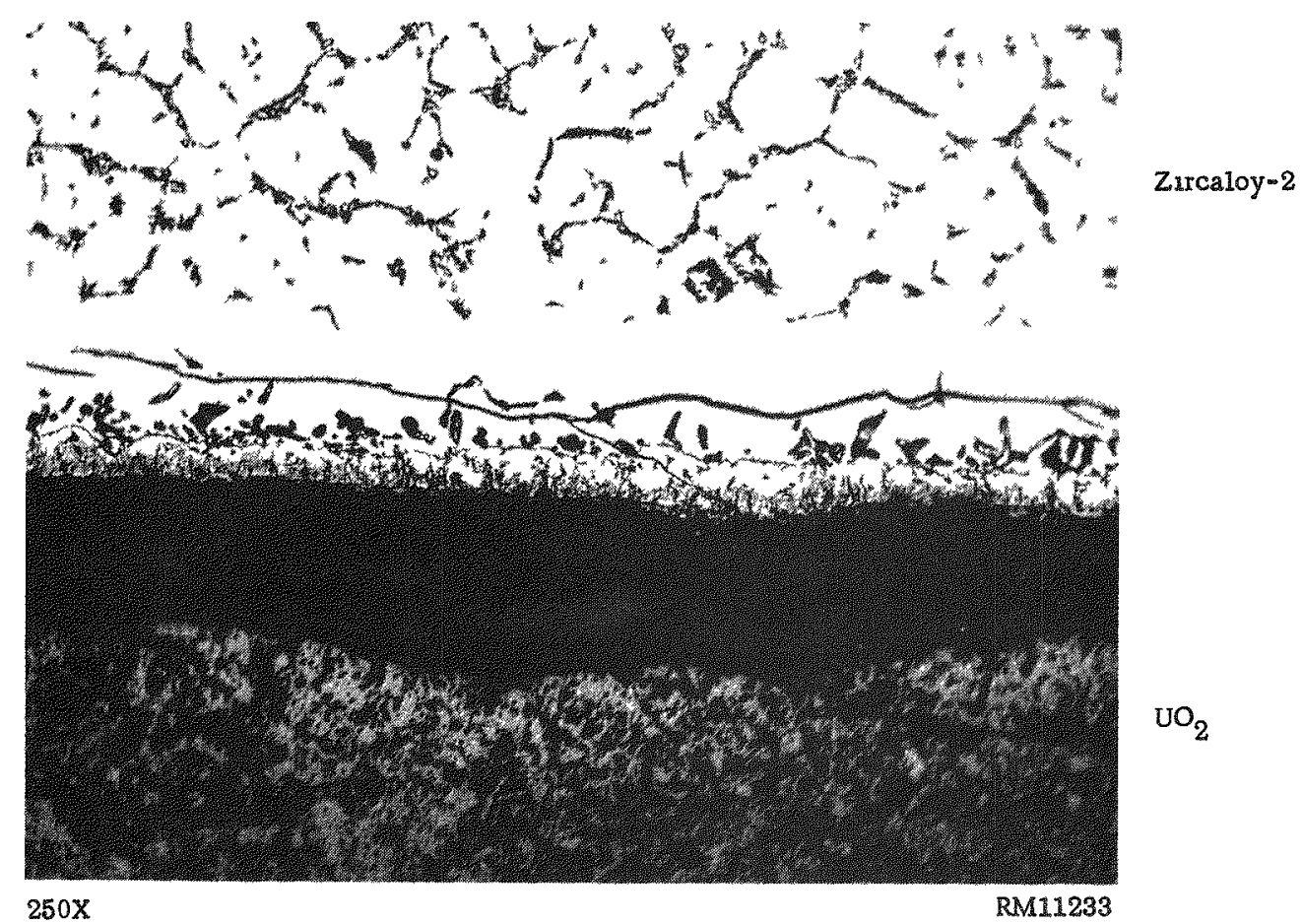

FIGURE 33. CRACKS SHOWING BRITTLENESS OF OXYGEN-RICH ZONE RESULTING FROM REACTION BETWEEN UNCOATED UO 2 CORE AND THE ZIRCALOY CLADDING 
much smaller uranium content $(0.002 \mathrm{w} / 0)$ than did those with uncoated cores $(0.5$ to $1 \mathrm{w} / 0)$. Bend tests showed that the uranium did not affect the ductility of the cladding.

Irradiation specimens bonded at Battelle containing cores coated with graphite by Bettis using a spray gun and Aquadag, a suspension of graphite in water, did not show evidence of core-cladding reaction, except in a few small areas. These were almost exclusively at the corners of cores where excessive flow of the cladding to fill void space caused the removal of the graphite. This indicated that the use of this method of coating the cores along with improved dimensional control to avoid void space and undersize ribs should reduce core-cladding reaction and associated problems in pressure-bonded elements.

Burst Tests

The results of the burst tests are summarized in Table 18. Except where noted, the deflection and bursting were restricted to the one compartment which had been defected in each element. The pressure required to burst samples ranged from 500 to 2800 psi, while the maximum deflection of the cladding before bursting ranged from 0.007 to $0.047 \mathrm{in}$. The first indication of deflection was observed at pressures as low as $100 \mathrm{psi}$ and as high as $2500 \mathrm{psi}$. Deflection increased gradually with increasing pressure in most specimens; however, in several specimens, no deflection was observed until the bursting pressure was reached. At the bursting pressure, the cladding in these specimens gradually deflected until bursting occurred. These types of failures were classified as gradual and sudden, respectively. The sudden fractures were characteristic of specimens containing bare cores in which excessive core-cladding reaction had resulted in the cladding being bonded to the core. This bond was not broken until a relatively high pressure was reached, and deflection and failure of the cladding then followed at the same pressure. The fractures could furthex be classified by their location on the side of the compartment containing the defect, the front, or on the side opposite the defect, the back. Failure of the cladding on the back side, which was the more normal behavior, occurred either by blowing off a portion of the cladding or by fracturing the cladding along the edge of the compartment. Figure 34 shows an example of a burst-tested element. On the front side, the failure consisted of a small break in the cladding after it had swelled in the vicinity of the seal ring over the defect. The results in Table 18 indicate that the strength and ductility of the cladding were significantly improved in specimens which had received a beta heat treatment.

Metallographic examination of elements which demonstrated poor behavior during burst testing indicated that a major cause for the erratic results was the brittle oxygenrich zone in areas surrounding the cores. These zones were observed most frequently at the corners of cores, where the graphite coating as well as particles of $\mathrm{UO}_{2}$ had apparently been removed from the core during flow of the cladding to accommodate undersize ribs. The brittleness of these zones is demonstrated by the cracks visible in such areas, as shown in Figures 32 and 33. Microhardness measurements in these zones show a hardness more than twice that of the Zircaloy in adjacent areas (Figure 31). The examination of metallographic sections indicated that the burst-test failures initiated from cracks in the brittle zone at core corners, where the stress from the applied gas pressure was also the highest. Figure 35 shows the progression of cracking in an area adjacent to where total failure occurred at a low pressure. Figure 36 is a photomicrograph of the corner of a core in another element showing cracks where failure could originate. 
TABLE 18. RESULTS OF BURST TESTS OF PRESSURE -BONDED FUEL ELEMENTS

\begin{tabular}{|c|c|c|c|c|c|c|c|c|c|c|c|}
\hline \multirow[b]{3}{*}{ Specimen } & \multirow{2}{*}{\multicolumn{3}{|c|}{ Bonding Conditions }} & \multirow[b]{3}{*}{$\begin{array}{l}\text { Core } \\
\text { Coating }\end{array}$} & & & \multicolumn{2}{|c|}{ Bursting Conditions } & \multirow[b]{3}{*}{$\begin{array}{l}\text { Type of } \\
\text { Failure }\end{array}$} & \multirow[b]{3}{*}{$\begin{array}{l}\text { Location of } \\
\text { Burst Failure }\end{array}$} & \multirow{3}{*}{$\begin{array}{l}\text { Occurrence of } \\
\text { Intercompart- } \\
\text { mental Leakage }\end{array}$} \\
\hline & & & & & \multicolumn{2}{|c|}{ Heat Treatment } & \multirow{2}{*}{$\begin{array}{l}\text { Bursting } \\
\text { Pressure, } \\
\text { psi }\end{array}$} & \multirow{2}{*}{$\begin{array}{l}\text { Maximum } \\
\text { Deflection, } \\
\quad \text { in. }\end{array}$} & & & \\
\hline & $\begin{array}{l}\text { Temperature, } \\
\text { F }\end{array}$ & $\begin{array}{l}\text { Time, } \\
\text { hr }\end{array}$ & $\begin{array}{l}\text { Pressure, } \\
\text { psí }\end{array}$ & & $\begin{array}{c}\text { Temperature, } \\
\text { F }\end{array}$ & $\begin{array}{l}\text { Time, } \\
\text { min }\end{array}$ & & & & & \\
\hline$P=2$ & 1500 & 4 & 10,000 & None & 1850 & 5 & 1900 & 0.042 & Gradual & $\begin{array}{l}\text { Back; } 80 \text { per cent of } \\
\text { cladding blown off } \\
\text { compartment }\end{array}$ & None \\
\hline$P-12$ & 1550 & 4 & 10,000 & Graphite & 1850 & 5 & 1600 & 0.038 & Gradual & $\begin{array}{l}\text { Back; } 80 \text { per cent of } \\
\text { cladding blown off } \\
\text { compartment }\end{array}$ & None \\
\hline$P-20$ & 1550 & 4 & 10,000 & Graphite & & & 700 & 0.009 & Sudden & $\begin{array}{l}\text { Back; burst along one } \\
\text { edge of compartment }\end{array}$ & None \\
\hline$P-30$ & 1525 & 4 & 10,000 & Graphite & & & 800 & 0.014 & Gradual & $\begin{array}{l}\text { Back; burst along one } \\
\text { edge of compartment }\end{array}$ & None \\
\hline $\mathrm{P}-36$ & 1500 & 4 & 10,000 & Graphite & & & 1100 & 0.044 & Sudden & $\begin{array}{l}\text { Back; burst along one } \\
\text { edge of compartment }\end{array}$ & None \\
\hline$P=40$ & 1550 & 4 & 10,000 & None & 1850 & 5 & 2500 & 0.019 & Sudden & $\begin{array}{l}\text { Back; } 80 \text { per cent of } \\
\text { cladding blown off } \\
\text { compartment }\end{array}$ & None \\
\hline$P \sim 44$ & 1450 & 4 & 10,000 & Graphite & & & 800 & 0.029 & Sudden & $\begin{array}{l}\text { Back; burst along one } \\
\text { edge of compartment }\end{array}$ & None \\
\hline$P=45$ & 1450 & 4 & 10,000 & Graphite & 1850 & 5 & 1100 & 0.047 & Gradual & Front; burst at seat & Leakage \\
\hline $\mathrm{P} \backsim 46$ & 1500 & 4 & 10,000 & Graphite & 1850 & 5 & 1500 & 0.038 & Gradual & $\begin{array}{l}\text { Back; } 40 \text { per cent of } \\
\text { cladding blown off } \\
\text { compartment }\end{array}$ & None \\
\hline$P=50$ & 1450 & 4 & 10,000 & Graphite & 1850 & 5 & 2800 & 0.046 & Gradual & Front; burst at seal & Leakage \\
\hline$P-57$ & 1500 & 4 & 10,000 & Graphite & & & 500 & 0.007 & Gradual & Front; burst at seal & Leakage \\
\hline$P \sim 58$ & 1500 & 4 & 10,000 & Graphite & 1850 & 5 & 700 & 0.027 & Gradual & $\begin{array}{l}\text { Back; edge of com- } \\
\text { partment and ad- } \\
\text { jacent compartment }\end{array}$ & Leakage \\
\hline $\mathrm{P}-74^{(\mathrm{a})}$ & 1450 & 4 & 10,000 & Graphite & 1850 & 5 & 1500 & 0.035 & Gradual & $\begin{array}{l}\text { Back; burst along one } \\
\text { edge of compartment }\end{array}$ & None \\
\hline
\end{tabular}

(a) Element contained stainless steel barrier between the spacers and cladding. 


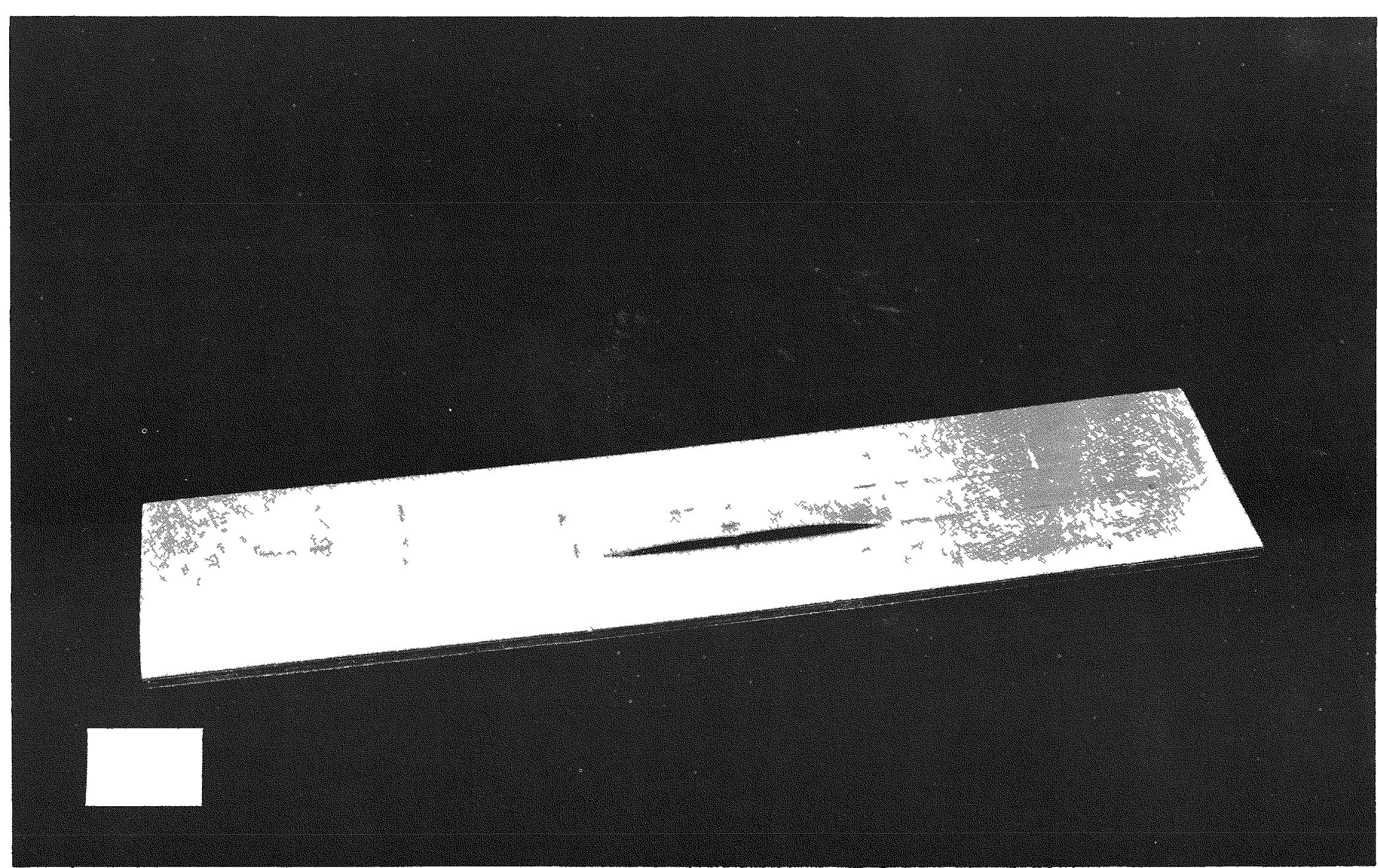

FIG URE 34. PRESSURE-BONDED ELEMENT WHICH WAS BURST TESTED

Failure of cladding occurred along the edge of a compartment at $1100 \mathrm{psi}$ after $0.044 \mathrm{~m}$. of deflection. This

element contaned graphite-coated cores. It was pressure bonded at $1500 \mathrm{~F}$ and $10,000 \mathrm{psi}$ for $4 \mathrm{hr}$ and was not heat treated. 


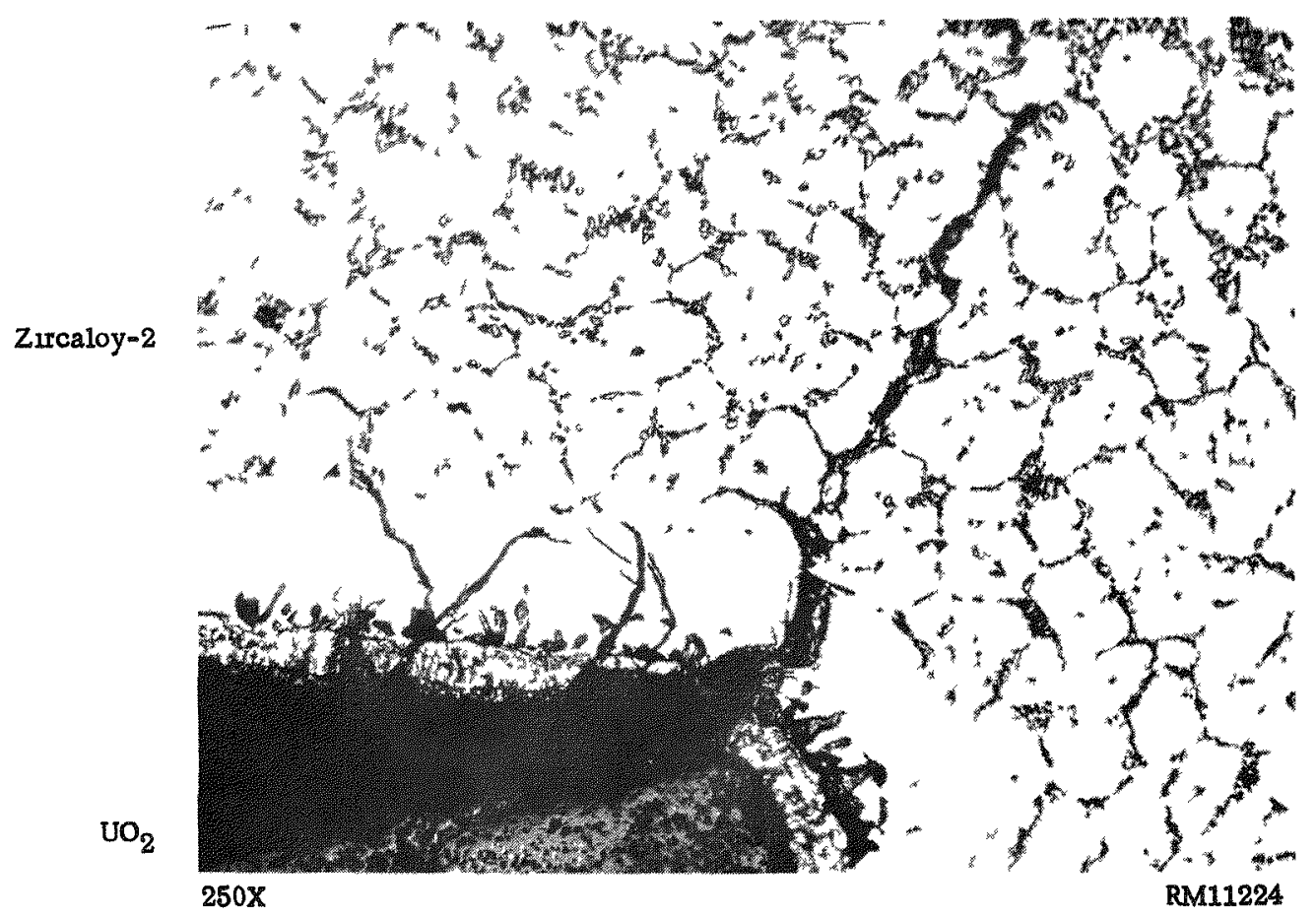

FIGURE 35. PROGRESSION OF CRACKING AT THE CORNER OF A CORE ADJACENT TO CORNER WHERE TOTAL FAILURE OCCURRED DURING BURST TESTING

Thus core was not graphite coated. Part of the core was removed during sectioning.

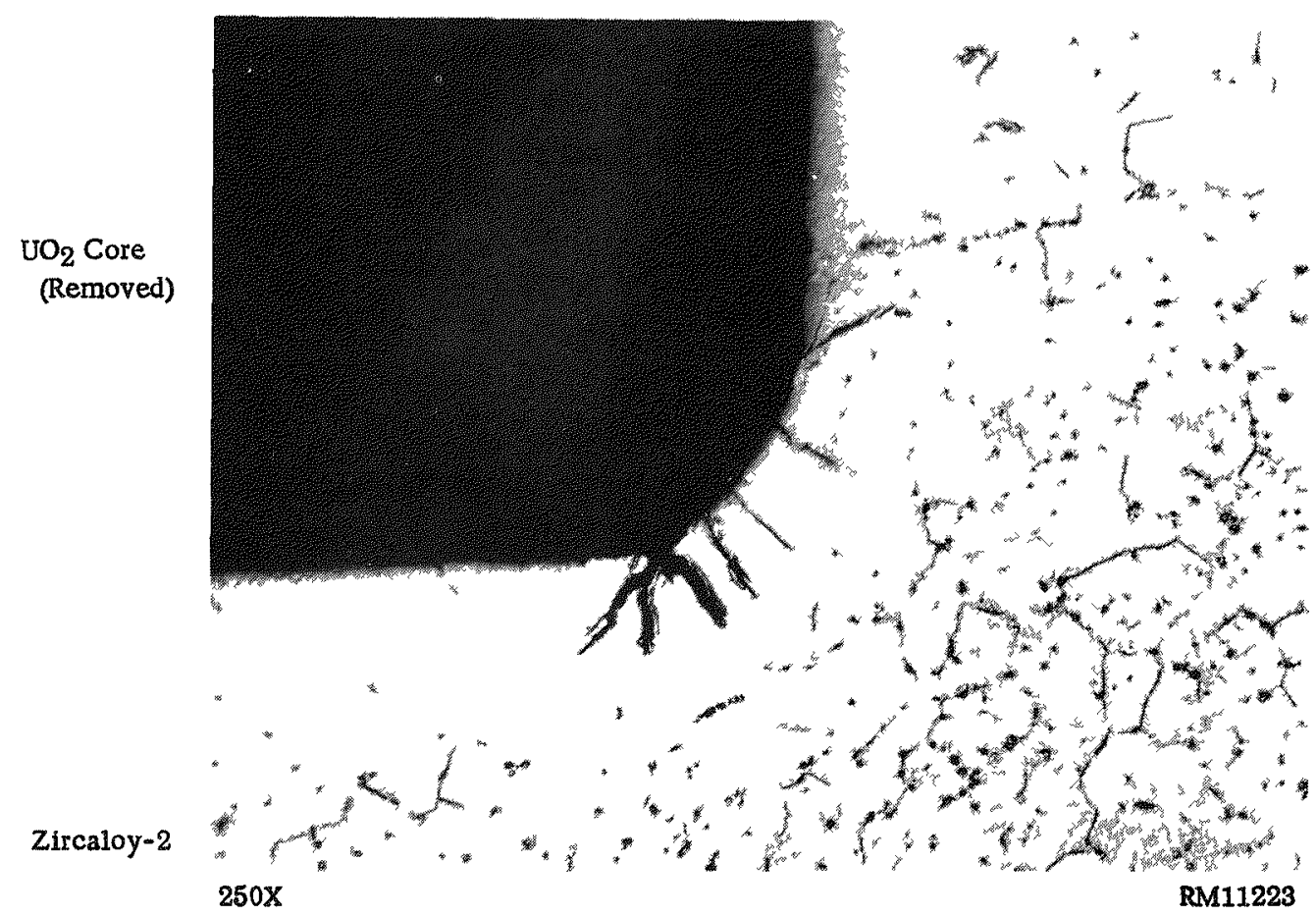

FIGURE 36. CRACKS AT A CORNER OF A GRAPHITE-COATED CORE

Failure could initiate at these cracks if stress were applied. The core was removed during sectioning. 
Only one of the beta-annealed elements $(P-58)$ demonstrated very poor behavior during burst testing. This element leaked between all compartments, which resulted in bulging of an entire end of the element. After considerable deflection, failure occurred at a low pressure due to increased stress produced by the large section of bulged cladding. Bend tests showed this cladding to be very ductile. The beta-treated elements, other than the one which failed in association with intercompartmental leakage, demonstrated reasonably good behavior during burst testing. However, the values of pressure and deflection at failure were not as high as should be achieved if the brittle oxygen-rich zone and thinning and contamination of the cladding were not present.

Thus, the inconsistent burst-test results were primarily obtained due to brittle oxygen-rich Zircaloy zones surrounding the cores and due to decreased cladding thickness as a result of flow to accommodate undersize ribs. The excessive flow of the cladding material in these areas may also have increased the extent of the brittle oxygenrich zone by rubbing away the graphite coating and particles of the $\mathrm{UO}_{2}$ core. Contamination of the cladding by hydrogen and iron also lowered the values obtained in burst testing.

Intercompartmental-Leakage Tests

The results of intercompartmental-leakage tests of elements before and after corrosion testing are presented in Table 19. Three of the fourteen specimens tested allowed pressurized gas to escape from one compartment into another. Two of the specimens leaked before corrosion testing while the third did not leak until after 4 days of exposure in $680 \mathrm{~F}$ water. These leaks were believed due to contamination of the bonds with graphite and oxide and to improper abrading of the xibs, since abrading was performed after the picture frames were punched. Those elements which contained bare cores exhibited swelling after corrosion testing while those containing graphite-coated cores did not swell. These results are the same as those observed in the other defectedcompartment corrosion tests.

Intercompartmental leakage between two or more compartments was observed in approximately 25 per cent of the specimens tested for intercompartmental failure or burst tested. A detailed study was made of the three specimens that failed by intercompartmental leakage, and a partial study was made on the remainder of these specimens. The major direct causes of failure appeared to be undersized ribs with subsequent deformation and thinning of the cladding and large particles of oxide and graphite between the cladding and core, which resulted in poor bonding. A fourth specimen that did not exhibit intercompartmental leakage was examined in a similar manner to determine if this specimen lacked any of the possible causes of defects observed in the elements that leaked between the compartments. This specimen did not contain any major defects, and was completely satisfactory except for very light contamination in some areas between the cladding and rib, which was observed to a greater or lesser degree in all of the specimens as a result of improper graphite coating and undersized ribs. It appeared that graphite had been transferred to some areas of the bonds from the graphite coatings on the cores during handling or during heating in the autoclave.

Radiographs were taken of these three specimens and part of the other bonded specimens in an attempt to verify the deposit of uranium between the cladding and $r$ ib in the form of particles of uranium oxide. A series of 14 specimens was examined in this manner. Eight of these exhibited spots of oxide along the rib with some of the ribs being heavily contaminated. Oxide was observed the full width and, in some cases, the full 
TABLE 19. RESULTS OF INTERCOMPARTMENTAL-LEAKAGE TESTS OF PRESSURE-BONDED FUEL ELEMENTS BEFORE AND AFTER CORROSION TESTING IN 680 F DEGASSED WATER

Specimens contained intentional defects.

\begin{tabular}{|c|c|c|c|c|c|c|c|c|c|c|}
\hline \multirow[b]{2}{*}{ Specimen } & \multicolumn{3}{|c|}{ Bonding Conditions } & \multirow[b]{2}{*}{$\begin{array}{l}\text { Core } \\
\text { Coating }\end{array}$} & Heat Trea & & \multicolumn{2}{|c|}{$\begin{array}{c}\text { Intercompartmental } \\
\text { Leakage } \\
\end{array}$} & \multirow{2}{*}{$\begin{array}{c}\text { Time on Test } \\
\text { in } 680 \mathrm{~F} \text { Water, } \\
\text { days }\end{array}$} & \multirow{2}{*}{$\begin{array}{c}\text { Thickness Increase } \\
\text { from Corrosion, } \\
\text { mils }\end{array}$} \\
\hline & $\begin{array}{l}\text { Temperature, } \\
\text { F }\end{array}$ & $\begin{array}{l}\text { Time, } \\
\mathrm{hr}\end{array}$ & $\begin{array}{l}\text { Pressure, } \\
\text { psi }\end{array}$ & & $\begin{array}{c}\text { Temperature, } \\
\text { F }\end{array}$ & $\begin{array}{l}\text { Time, } \\
\text { min }\end{array}$ & $\begin{array}{l}\text { Before } \\
\text { Corrosion }\end{array}$ & $\begin{array}{l}\text { After } \\
\text { Corrosion }\end{array}$ & & \\
\hline $\mathrm{P} \sim 68$ & 1550 & 4 & 10,000 & Graphite & \multicolumn{2}{|c|}{ None } & No & Yes & 4 & None \\
\hline $\mathrm{P}-4$ & 1550 & 4 & 10,000 & None & 1850 & 5 & No & No & 10 & $11-13$ \\
\hline $\mathrm{P}-5$ & 1550 & 4 & 10,000 & Graphite & 1850 & 5 & No & No & 11 & None \\
\hline$P-6$ & 1550 & 4 & 10,000 & None & 1850 & 5 & No & No & 11 & $6-15$ \\
\hline $\mathrm{P} \sim 8$ & 1550 & 2 & 10,000 & None & \multicolumn{2}{|c|}{ None } & No & No & 11 & $3-7$ \\
\hline$P-10$ & 1550 & 4 & 10,000 & None & 1850 & 5 & No & No & 10 & $11-17$ \\
\hline$P-11$ & 1550 & 4 & 10,000 & Graphite & 1850 & 5 & No & No & 11 & None \\
\hline $\mathrm{P}-14$ & 1550 & 4 & 10,000 & Graphite & 1850 & 5 & No & No & 10 & None \\
\hline$P-39$ & 1550 & 4 & 10,000 & None & 1850 & 5 & No & No & 11 & $8-11$ \\
\hline$P-47$ & 1500 & 4 & 10,000 & Graphite & 1850 & 5 & Yes & Yes & 4 & None \\
\hline$P-52$ & 1450 & 4 & 10,000 & Graphite & 1850 & 5 & Yes & Yes & 4 & None \\
\hline$P-71$ & 1450 & 4 & 10,000 & Graphite & 1850 & 5 & No & $m$ & None & $-\infty$ \\
\hline $\mathrm{P} \times 73$ & 1450 & 4 & 10,000 & Graphite & 1850 & 5 & No & $\infty$ & None & - \\
\hline$p-74$ & 1450 & 4 & 10,000 & Graphite & 1850 & 5 & No & - & None & $\cdots$ \\
\hline
\end{tabular}


length of the compartment. Since all of the specimens examined had been subjected to some type of testing, it was felt that some of the oxide may have been introduced during testing rather than during assembly or bonding. Examination of an as-bonded specimen, however, revealed sufficient contamination to produce intercompartmental failure during leak or burst testing by complete failure of the cladding-to-rib bonds.

A dimensional study was made of these specimens which had exhibited intercompartmental leakage and was also made on a punched receptacle that had been abraded for bonding. In some instances, ribs were found to have been excessively abraded in some areas until they were only 57 to $58 \mathrm{mils}$ in height, as compared to an intended height of 80 to 82 mils. Undersized ribs were observed in all of the specimens and were very obvious in the defective specimens. The excessive flow necessary to fill the void space of a rib 20 mils undersize results in thinning of the cladding and rubbing of the graphite and oxide from the corners of the cores as flow occurs. Also, the effective pressure may be reduced to a point where it is no longer adequate to produce bonding between the ribs and cladding, and a complete change in the surface condition of the cladding may occur during the excessive flow. The effect of thin cladding on burst-test results has been discussed. The rubbing off of the oxide during the excessive flow is apparent from the pattern of the oxide-containing layers between the ribs and cladding plates. Excessive oxide was pushed into the interfaces nearer the core and lesser amounts further away from the core. If an extensive amount of flow is required to fill a void space, the effective pressure exerted through the can, spacers, and the cladding-to-rib interface may approach a value insufficient to produce flow. In pointing out the seriousness of the problem of undersized ribs, it should be kept in mind that this is not encountered in $r e-$ ceptacles punched from previously abraded stock and is not a serious problem in bonding piece components, which will be discussed in a later section.

The cause of the defects observed in the specimens exhibiting intercompartmental leakage can be minimized or eliminated by improving the graphite coatings, using ribs abraded to the proper thickness, and assembling the specimens in a horizontal plane and handling the specimens in a like manner until they are inserted for pressure bonding. The rib dimensions can be controlled by abrading before punching or using piece components. Improved graphite coatings can be obtained by spraying Aquadag instead of brushing Neolube on the cores.

Waterlogging Tests

Waterlogging tests were conducted on two fuel elements bonded $4 \mathrm{hr}$ at $1500 \mathrm{~F}$ and $10,000 \mathrm{psi}$. The cores in one element were coated with graphite and those in the other element were bare. Both specimens were heat treated for $5 \mathrm{~min}$ in a salt bath at $1850 \mathrm{~F}$ after bonding. The elements were corrosion tested $18 \mathrm{hr}$ in $680 \mathrm{~F}$ water prior to immersion in $700 \mathrm{~F}$ molten lead.

All fuel compartments in the specimens with bare cores were bulged after corrosion testing as a result of corrosion of the reaction zone between the cladding and the cores. Thickness increases ranged from 0.009 to 0.011 in. Total weight gain of the element was in excess of $3 \mathrm{~g}$, indicating the possibility of waterlogging. When the element was plunged into the molten lead, sufficient steam was released to cause a quantity of the lead to bubble out of the container. For this reason, the top three compartments were not covered by the lead. Severe swelling occurred in the remainder of the compartments, resulting from steam being generated in the waterlogged cores. Thickness increases of the element ranged from 0.032 to $0.074 \mathrm{in}$. 
There was no detectable swelling after coxrosion testing of the element containing graphite barrier layers. However, the element exhibited a weight increase of about $0.8 \mathrm{~g}$, indicating the possibility of waterlogging of the cores. Upon immersion in the molten lead, three of the nine compartments bulged. Over-all thickness increases over these compartments ranged from 0.010 to $0.044 \mathrm{in.}$. It is felt that, even with no coreto-cladding reaction and a minimum amount of void space in the compartments as a result of metal flow during pressure bonding, the cores may still waterlog. However, it should be kept in mind that this test is much more severe than can be expected in reactor operation. Heating and cooling of the elements during reactor operation are slow enough to permit some of the steam to flow from the defect hole. In the waterlogging test, the element is plunged into the lead bath and the pressure buildup is very rapid.

\section{Zircaloy -2 Corrosion Tests}

Corrosion results obtained in 750 F 1500 -psi steam for the Zircaloy-2 coupons taken from a corner of the fuel elements are summarized in Table 20. After 7 days of exposure, all but two samples were covered with adherent black films and had weight gains of less than $20 \mathrm{mg}$ per $\mathrm{dm}^{2}$. This behavior is normal for Zircaloy-2 exposed under these conditions. The other two samples exhibited a gray film and weight gains of $42 \mathrm{mg}$ per $\mathrm{dm}^{2}$. These coupons came from fuel elements which had not been beta heat treated; all other specimens were from fuel elements which had been heat treated for $5 \mathrm{~min}$ at $1850 \mathrm{~F}$.

TABLE 20. CORROSION RESULTS OBTAINED IN $750 \mathrm{~F}$ 1500 PSI STEAM FOR ZIRCALOY -2 COUPONS CUT FROM PRESSURE BONDED FUEL ELEMENTS

\begin{tabular}{|c|c|c|c|c|c|c|c|c|}
\hline \multirow[b]{2}{*}{ Specimen } & \multicolumn{3}{|c|}{ Bonding Conditions } & \multicolumn{2}{|c|}{ Heat Treatment } & \multirow[b]{2}{*}{$\begin{array}{c}\text { Exposure Time, } \\
\text { days }\end{array}$} & \multirow[b]{2}{*}{$\begin{array}{l}\text { Total Weight } \\
\text { Gain, mg per dm }\end{array}$} & \multirow[b]{2}{*}{ Appearance } \\
\hline & $\begin{array}{c}\text { Temperature, } \\
\text { F }\end{array}$ & $\begin{array}{l}\text { Time, } \\
\text { hr }\end{array}$ & $\begin{array}{l}\text { Pressure, } \\
\text { psi }\end{array}$ & $\begin{array}{c}\text { Temperature, } \\
\text { F }\end{array}$ & $\begin{array}{l}\text { Time, } \\
\text { min }\end{array}$ & & & \\
\hline$P=8$ & 1550 & 2 & 10,000 & None & & 7 & 42 & Gray mottle \\
\hline$p-9$ & 1550 & 4 & 10,000 & None & & 7 & 42 & Gray film \\
\hline$P-4$ & 1550 & 4 & 10,000 & 1850 & 5 & 7 & 18 & Black film \\
\hline$P=5$ & 1550 & 4 & 10,000 & 1850 & 5 & 7 & 19 & Black film \\
\hline$P-6$ & 1550 & 4 & 10,000 & 1850 & 5 & 7 & 13 & Black film \\
\hline$P-10$ & 1550 & 4 & 10,000 & 1850 & 5 & 7 & 19 & Black film \\
\hline$P-11$ & 1550 & 4 & 10,000 & 1850 & 5 & 7 & 8 & Black film \\
\hline$P-14$ & 1550 & 4 & 10,000 & 1850 & 5 & 7 & 11 & Black film \\
\hline$P-39$ & 1550 & 4 & 10,000 & 1850 & 5 & 7 & 14 & Black film \\
\hline$P-47$ & 1500 & 4 & 10,000 & 1850 & 5 & 3 & 11 & Black film \\
\hline
\end{tabular}

Evaluation of Gas-Pressure-Bonded 3-Ft-Long Fuel Element

One element of the same configuration as the other elements bonded in protective cans except for greater length was pressure bonded to determine problems which might be encountered during bonding of a long element. This element was approximately $3 \mathrm{ft}$ in length and had belt-abraded cladding components that were punched prior to belt abrading. Stainless steel shims were placed between the Zircaloy and the chromiumplated Ti-Namel spacers to minimize diffusion between the cladding and the spacers This element, shown in Figure 37, gave very encouraging results. No difficulties were presented in bonding or removing the element from its envelope and spacers, and no warping occurred. There was also no apparent edge effect or cladding embrittlement in 


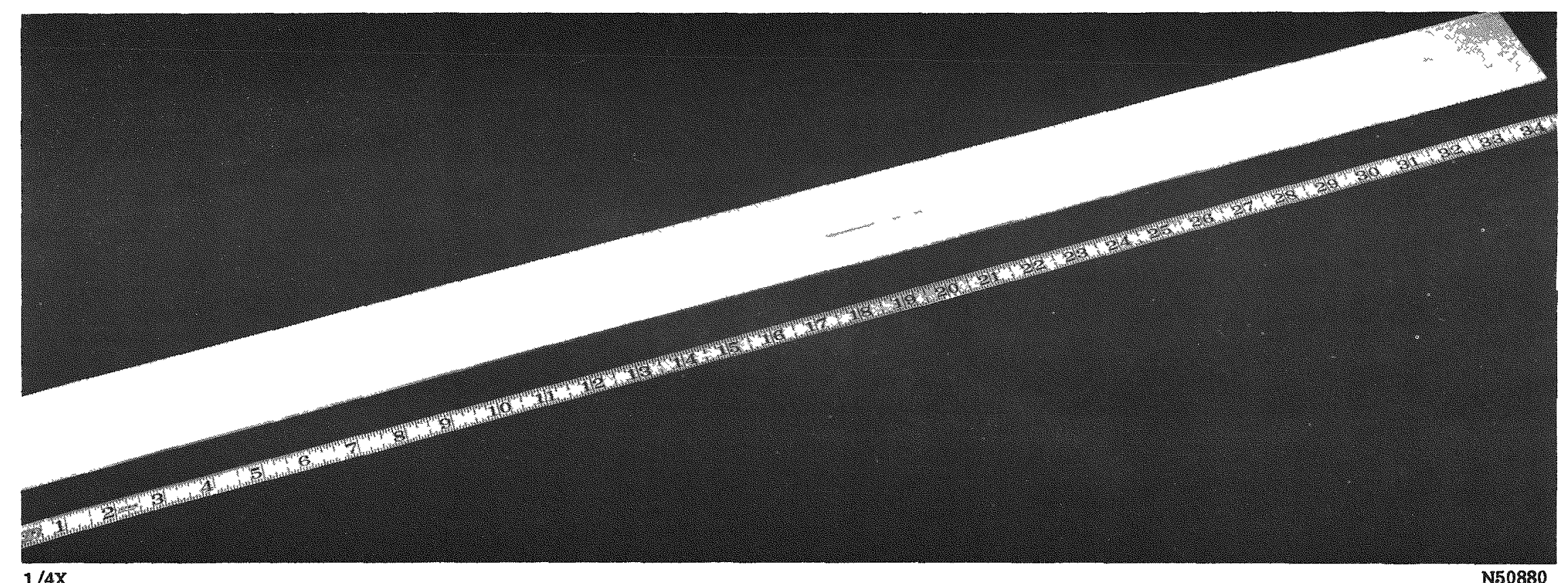

FIGURE 37. ZIRCALOY-CLAD FLAT-PLATE UO 2 FUEL ELEMENT PRESSURE BONDED AT 1450 F FOR 4 HR WITH A 10,000 PSI HELIUM PRESSURE Approximate length of element was 3 ft. Element was pressure bonded in a protective container. 
this specimen. Metallographic examination of the element revealed good bonding; a sample which was bend tested showed no separation of the bond.

Investigation of Bonding Fuel Elements Prepared With Piece Zircaloy Components

Three specimens were pressure bonded in protective containers using strip components to form the compartmented picture frames of the elements; this type of picture frame has an economic advantage over the one-piece punched frame. The specimens were prepared to determine if good bonds could be obtained between all sides of the various components to produce elements without any intercompartmental leakage. Each of the specimens had a different frame configuration as shown in Figure 38 . Components for a picture frame of this type are shown assembled in Figure 39. The specimens had machined bonding surfaces for this cursory study. Stainless steel shims were placed between the Ti-Namel containers, as illustrated in Figure 39. Pressure bonding was performed at $1450 \mathrm{~F}$ and $10,000 \mathrm{psi}$ for $4 \mathrm{hr}$. After pressure bonding, the elements were heat treated for $5 \mathrm{~min}$ in a salt bath at $1850 \mathrm{~F}$.

The elements were visually inspected for improper shifting of components during bonding, and apparently no such difficulties had occurred. The elements were all tested for intercompartmental leakage by the procedure already described. No leaks were found in any of the specimens, indicating a high degree of bond integrity. The bonds between the picture-frame $r$ ibs and the cladding plates could not be caused to fail in peel tests, nor could the bonds along the edges. A very narrow edge effect, detected by peel testing, was present only along one side of one of the elements. An element which was burst tested exhibited good behavior, failing at 1400 psi after 0.035 in. of deflection of the cladding. The failure did not extend to compartments other than the one under test, demonstrating no intercompartmental leakage. No cladding embrittlement was observed in these elements, which had stainless steel barriers between the spacers and cladding.

Metallographic examination revealed generally good bonds between the ribs and the cladding plates. Although light contamination was visible in some areas along these bond interfaces, grain growth had occurred across the interface. The bonds of the various sheared ends of the $r$ ibs and edge strips to each other showed discontinuous areas where there was no grain growth across the bond line. This was caused by not subjecting the sheared surfaces to an additional surface-preparation treatment.

The results of this study demonstrated that strong leaktight bonds could be obtained using a frame composed of piece components. The metallographic evaluation, however, indicated that all mating surfaces of the element components should be surface prepared to avoid areas without bond-line grain growth. 
(a)

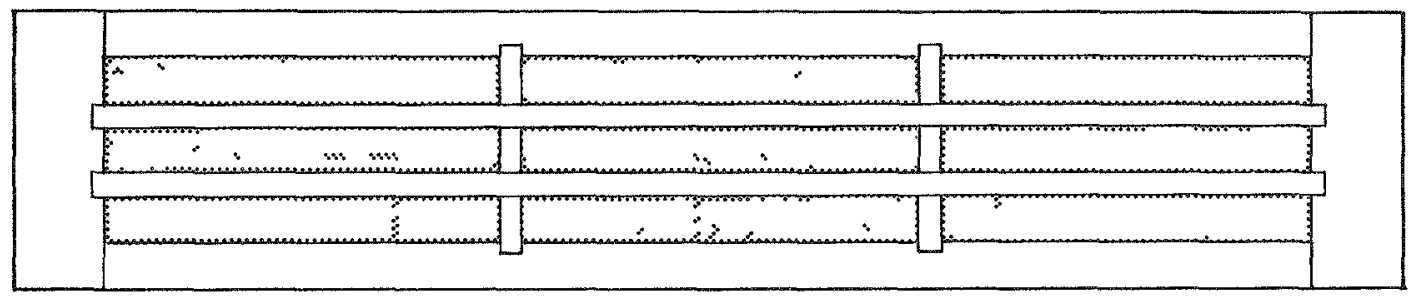

(b)
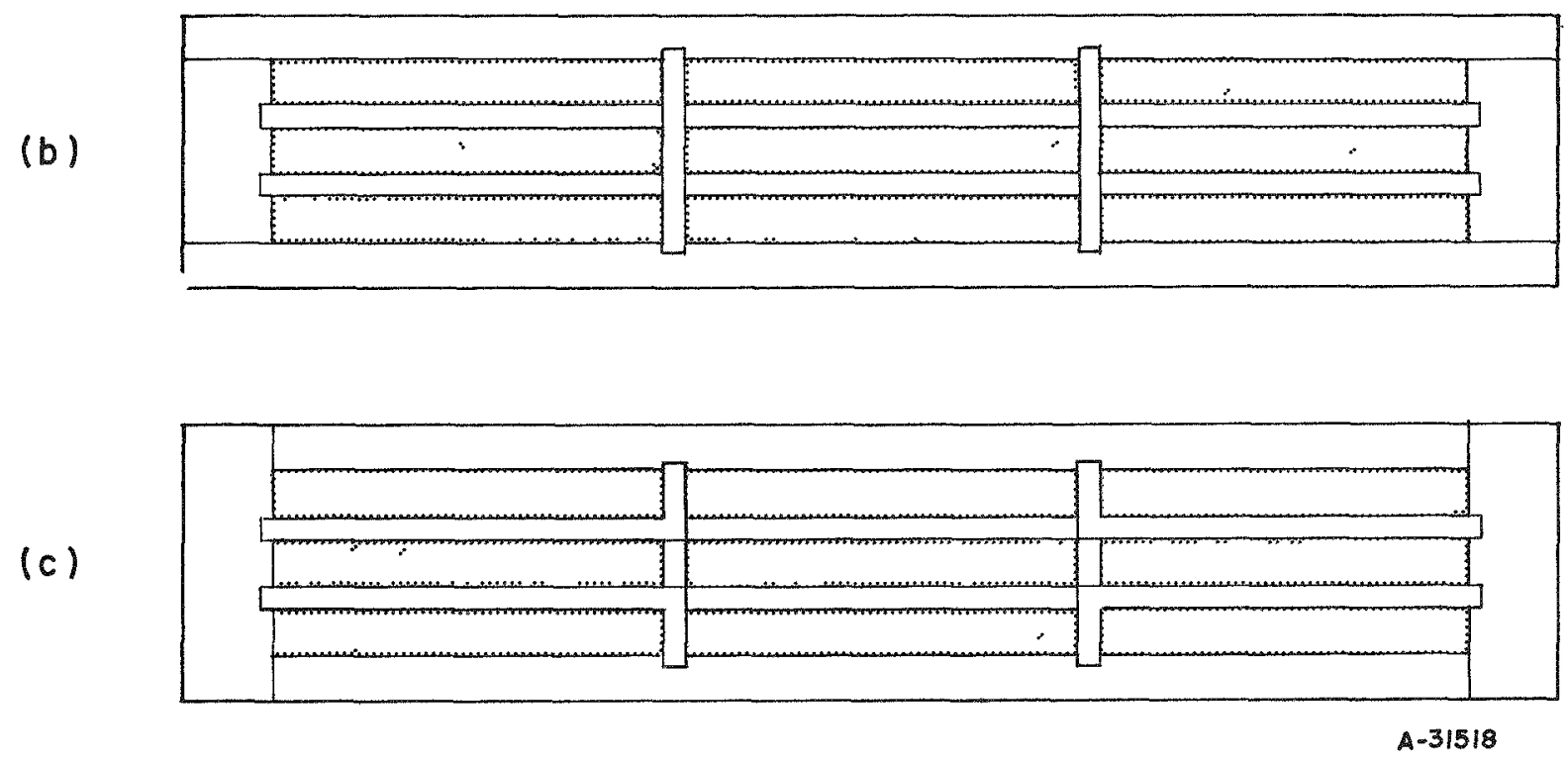

FIGURE 38. CCNFIGURATIONS OF PIECE-COMPONENT PIC TURE FRAMES USED IN THREE PRESSURE-BONDED FUEL ELEMENTS PREPARED IN PROTECTIVE CONTAINERS 


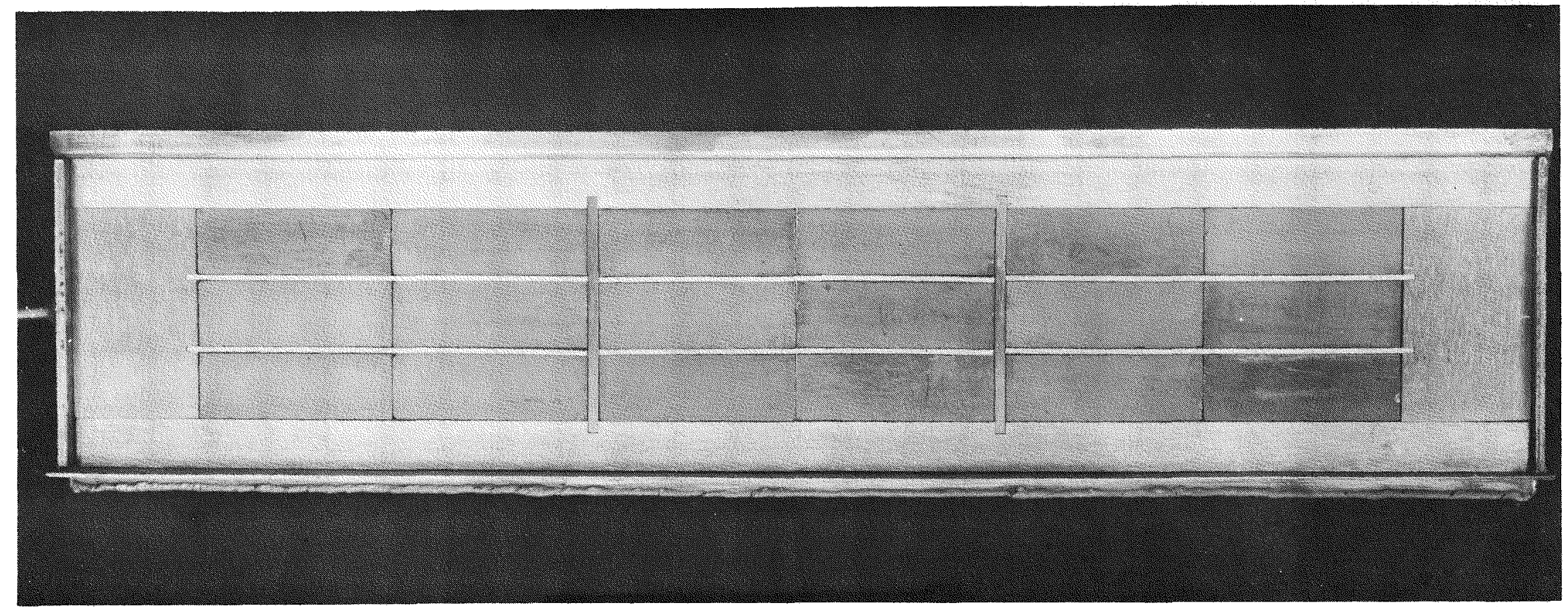

FIGURE 39. PHOTOGRAPH OF A PICTURE FRAME ASSEMBLED FROM PIECE COMPONENTS AND CONT AINING UO ${ }_{2}$ CORES

Specimen is shown assembled into protective container. After the top cladding and spacer plates were added, the final side of the container was welded in position. 


\section{GAS-PRESSURE BONDING OF EDGE-WELDED ELEMENTS}

Several series of the flat-plate Zircaloy-clad fuel elements containing compartmented uranium dioxide cores were pressure bonded without use of a protective container. The edges of the components were fusion welded to form a gastight assembly. Where applicable, techniques developed in previous phases of the program were incorporated in the preparation of these elements. Edge-welding of the cladding components of an element was studied because it affords several distinct advantages as compared with assembling the components into a container for bonding. Because the edges are welded, elements prepared by this technique should not be susceptible to an edge effect. Also, contamination of the cladding material with iron from the Ti-Namel spacers is, of course, eliminated. The picture frames for these elements were assembled from strip Zircaloy components, except for a number of preliminary elements which were prepared using one-piece punched picture frames. The use of piece-component picture frames is advantageous because of the difficulty of punching large frames to proper tolerances and because less Zircaloy is required.

Based on the process study of the elements pressure bonded in containers, several modifications in addition to edge welding and piece-component picture frames were incorporated into the study. The graphite coatings applied to the uranium dioxide cores to serve as a barrier to core-cladding reaction were sprayed onto the cores using Aquadag, a suspension of graphite in water, instead of brushing on a coating of Neolube, a suspension of graphite in alcohol. As discussed earlier, results of a few specimens containing cores with the sprayed Aquadag coatings indicated that this coating was more adherent and uniform. Also, in these specimens the thickness of the ribs was controlled so that they were as thick, or several thousandths of an inch thicker, than the cores in order to prevent excessive flow of the cladding plates.

Fusion edge welding of these elements was performed in a helium-atmosphere tank to avoid contamination of the Zircaloy during welding. The specimens for the preliminary studies and the initial specimens in the process-development study were not evacuated before final sealing and contained an atmosphere of air. Later, it was established that evacuation would be necessary, and two techniques were developed for evacuating the elements during final sealing, as discussed in a subsequent section.

The investigation of the preparation of elements by the edge-welding technique utilizing a piece-component picture frame consisted of preliminary studies and a process-development study. The purpose of the preliminary studies was to determine the feasibility of the technique and to determine if the basic studies of surface preparations and bonding parameters for specimens bonded in containers were applicable for edge-welded specimens. The process-development study consisted of bonding a large number of elements in order to develop techniques for producing consistently satisfactory elements by this method. The elements were evaluated in both the as-bonded condition and after a $5-\mathrm{min}$ heat treatment in an $1850 \mathrm{~F}$ salt bath. The tests used for the evaluation of these series of specimens included visual examination, metallographic examination of bond quality and core-cladding reaction, peel tests of bonds, intercompartmental-leakage tests, burst tests of compartments, corrosion tests of purposely defected compartments, and chemical analyses. 
PRELIMINARY STUDIES OF EDGE-WELDED ELEMENTS

Two preliminary series of elements were pressure bonded utilizing fusion welding of the edges of the cladding plates to the edges of the picture frame in order to determine the feasibility of this technique. Exploratory investigations of bonding parameters and surface preparation were included to assure that results obtained in previous studies with specimens bonded in containers were also applicable to edge-welded specimens. The first series of specimens was prepared using one-piece punched picture frames; the second series utilized piece-component picture frames to determine the feasibility of bonding leaktight specimens by this method.

\section{Specimens With One-Piece Punched Picture Frames}

Eleven edge-welded specimens incorporating punched picture frames were gaspressure bonded. The components for the se elements were the same as those which were used for the process-development study of elements bonded in containers (shown in Figure 2). Five of the eleven elements had cladding plates and picture frames which were belt abraded under the same conditions as the enveloped specimens. The remaining six elements were prepared with components which had been pickled in 5 volume per cent $\mathrm{HF}-45$ volume per cent $\mathrm{HNO}_{3}-50$ volume per cent $\mathrm{H}_{2} \mathrm{O}$. The cores for these elements were not graphite coated, since it was desired to eliminate all possible sources of contamination in order to isolate the effect of the welding operation. After fusion welding the edges of the elements in a helium-atmosphere tank, the final closure was made with air instead of helium sealed inside the element, as described in the previous section on assembly of components. It was considered that entrapped air would be preferable to helium, since part of the air might be absorbed by the Zircaloy during bonding. It was desired to determine from the preliminary studies whether evacuation of the elements would be necessary. The six pickled elements were bonded using various conditions of temperature and pressure as described in Table 21; the belt-abraded elements were bonded at $1550 \mathrm{~F}$ and 10,000 psi for $4 \mathrm{hr}$. All of the elements received a 5-min heat treatment in an $1850 \mathrm{~F}$ salt bath after bonding.

Information obtained from metallographic evaluation of the bonds in some of these elements is tabulated in Table 21. The bonding obtained using belt-abraded components appeared very promising and is illustrated in Figure 40 . Bonding in the pickledcomponent specimens was not consistent, as was found in the surface-preparation study, but was generally of fair quality at the higher bonding temperatures. There was no edge effect visible in the samples examined, such as had been found in the specimens bonded in a protective container, and apparently no contamination of the bonding surfaces of the components had resulted from the welding operation. The core-cladding reaction, as observed metallographically, was excessive due to the bare cores. No visible hydriding or other contamination had occurred. 
TABLE 21. METALLOGRAPHIC RESULTS OE EDGE-WELDED SPECIMENS WITH ONE-PIECE PICTURE FRAMES

All samples heat treated for $5 \mathrm{~min}$ at $1850 \mathrm{~F}$ subsequent to pressure bonding.

\begin{tabular}{|c|c|c|c|c|c|c|c|}
\hline \multirow[b]{2}{*}{ Specimen } & \multirow[b]{2}{*}{ Surface Preparation } & \multicolumn{3}{|c|}{ Pressure-Bonding Conditions } & \multicolumn{3}{|c|}{ Bond Results } \\
\hline & & $\begin{array}{c}\text { Temperature, } \\
\text { F }\end{array}$ & $\begin{array}{c}\text { Tume, } \\
\mathrm{hr}\end{array}$ & $\begin{array}{c}\text { Pressure, } \\
\text { psi }\end{array}$ & $\begin{array}{l}\text { Type A, } \\
\text { per cent }\end{array}$ & $\begin{array}{l}\text { Type } B, \\
\text { per cent }\end{array}$ & $\begin{array}{l}\text { Type C, } \\
\text { per cent }\end{array}$ \\
\hline AR -2 & Pickled & 1200 & 4 & 3,500 & 0 & 3 & 97 \\
\hline$A R-1$ & Pickled & 1350 & 4 & 3,500 & 6 & 90 & 4 \\
\hline$A R=5$ & Prckled & 1400 & 4 & 5,000 & 80 & 20 & $\cdots$ \\
\hline AR-6 & Pickled & 1400 & 4 & 5,000 & 40 & 60 & -- \\
\hline$A R-3$ & Pickled & 1500 & 4 & 5,000 & 70 & 30 & -- \\
\hline $\mathrm{AR}-4$ & Pickled & 1500 & 4 & 5,000 & 5 & 95 & -- \\
\hline$A R-39$ & Belt abraded & 1550 & 4 & 10,000 & 75 & 25 & -- \\
\hline
\end{tabular}

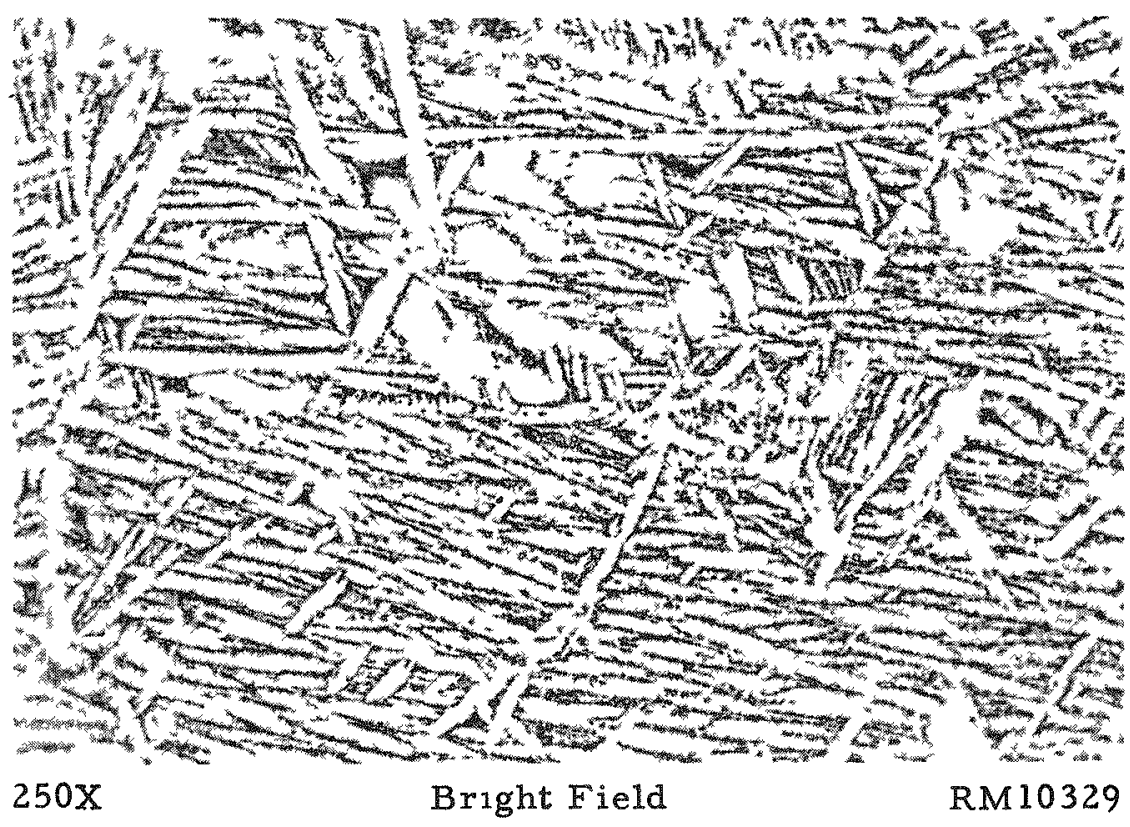

Bond interface

FIGURE 40. ZIRCALOY-TO-ZIRCALOY BOND IN ELEMENT PREPARED

BY EDGE WELDING THE COMPONENTS PRIOR TO

PRESSURE BONDING INSTEAD OF INSERTING THEM INTO A PROTECTIVE CONTAINER

The bond between cladding plate and rib of the one-plece picture frame is shown here. The element contained beltabraded cladding components, and was pressure bonded at $1550 \mathrm{~F}$ and $10,000 \mathrm{psi}$ for $4 \mathrm{hr}$ and heat treated at $1850 \mathrm{~F}$ for $5 \mathrm{~min}$ in a salt bath. 
One of the belt-abraded specimens was tested for intercompartmental leakage in the manner described previously. There was no leakage between compartments either before or after corrosion testing in $680 \mathrm{~F}$ water for 11 days, although 0.008 to $0.011 \mathrm{in}$. of swelling occurred in corrosion because no barrier layer was used. Another one of these belt-abraded specimens was burst tested by the method discussed earlier, and bursting occurred at 2500 psi after 0.019 in. of deflection. This was more deflection than anticipated, since the lack of a barrier layer between core and cladding has been found to reduce the amount of deflection during burst testing, due to the cladding sticking to the cores. This element after testing is shown in Figure 41 . The ductility of the cladding of an element at the end, edge, and $\mathrm{rib}$, and of the cladding plate over a core, was also examined by bend testing to determine if any embrittlement had occurred due to the material being exposed to the autoclave atmosphere. The specimens demonstrated excellent ductility giving $T$-values (die radius/specimen thickness) of less than 1.5 in all areas. Vacuum-fusion analyses of the Zircaloy cladding showed a hydrogen content of 91 to $130 \mathrm{ppm}$ and an oxygen content of about $1230 \mathrm{ppm}$. In a peel test of a beltabraded specimen, the cladding itself failed before the bond along the ribs or edges could be ruptured. No edge effect was observed in the test. During a 7-Jay corrosion test in $750 \mathrm{~F}$ steam, a piece of Zircaloy-2 from an edge-welded specimen showed good corrosion behavior, forming a typical black film characteristic of corrosion-resistant Zircaloy. The results thus showed that the technique of fusion edge welding the elements prior to pressure bonding was feasible for the preparation of this type of fuel element.

Specimens With Piece-Component Picture Frames

Eight small edge-welded specimens were gas-pressure bonded utilizing picture frames assembled from strip components. The purpose of these preliminary specimens was to determine the feasibility of preparing leaktight elements by this technique. Each of these small specimens contained four uranium dioxide cores, which were 1.500 by 0.500 by 0.100 in., separated by $0.100-$ in. -wide Zircaloy ribs. The ribs were prepared $0.002 \mathrm{in}$. thicker than the cores. A drawing of the assembled frame and cores is shown in Figure 42. The specimens had all belt-abraded components, all pickled components, or abraded cover plates in contact with pickled frame components. The pickling solution used was 5 volume per cent $\mathrm{HF}-45$ volume per cent $\mathrm{HNO}_{3}-50$ volume per cent alcohol. The cores were coated with a thin layer of graphite applied by spray coating with Aquadag and outgassed at $750 \mathrm{~F}$, as described in detail in a subsequent section. The average amount of coating applied was approximately $1.0 \mathrm{mg}$ of graphite per in. 2 of core surface. After edge welding, the specimens were sealed containing air, as described previously. Pressure bonding was performed at 10,000 psi for $4 \mathrm{hr}$ at a temperature of 1550 or $1750 \mathrm{~F}$. Some of the elements were heat treated at $1850 \mathrm{~F}$ for 5 min in a salt bath after bonding.

Sections of the specimens were examined metallographically for quality of bonding and extent of core-cladding reaction. The results of the metallographic study of the bonds are contained in Table 22. As was found for the enveloped elements, the specimens with all belt-abraded components showed generally good bonding at $1550 \mathrm{~F}$, especially after the additional 5-min heat treatment at $1850 \mathrm{~F}$. The bonds of the frame components to each other were comparable with those between the frame components and the cladding plates, which indicated that piece-component frames could be satisfactorily bonded. The bonds obtained between the belt-abraded components are 


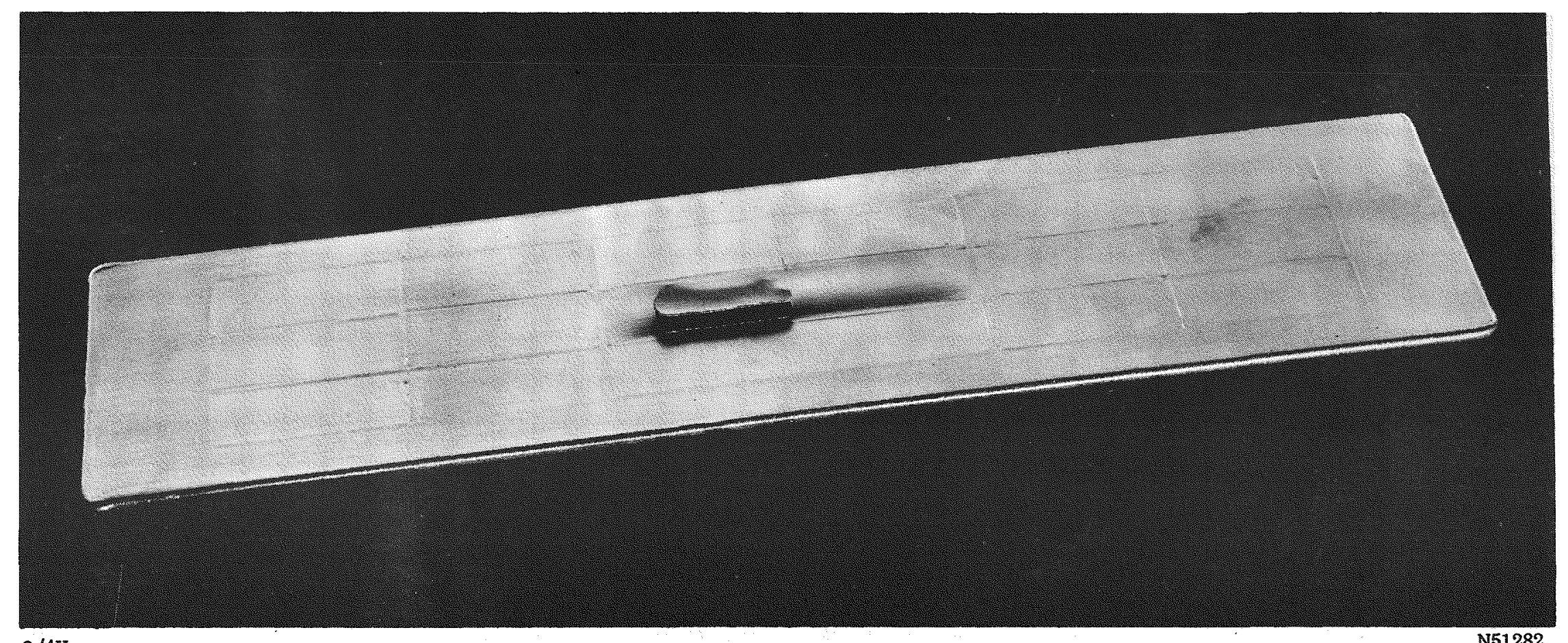

FIGURE 41. BURST-TESTED PRESSURE-BONDED ELEMENT PREPARED UTILIZING EDGE WELDING

Failure of cladding occurred along edge of compartment and across it at $2500 \mathrm{psi}$ after $0.019 \mathrm{in}$. of deflection. The element contained a one-piece picture frame and bare cores, and was heat treated at $1850 \mathrm{~F}$ for $5 \mathrm{~min}$ after pressure bonding at $1550 \mathrm{~F}$ and $10,000 \mathrm{psi}$ for $4 \mathrm{hr}$. 


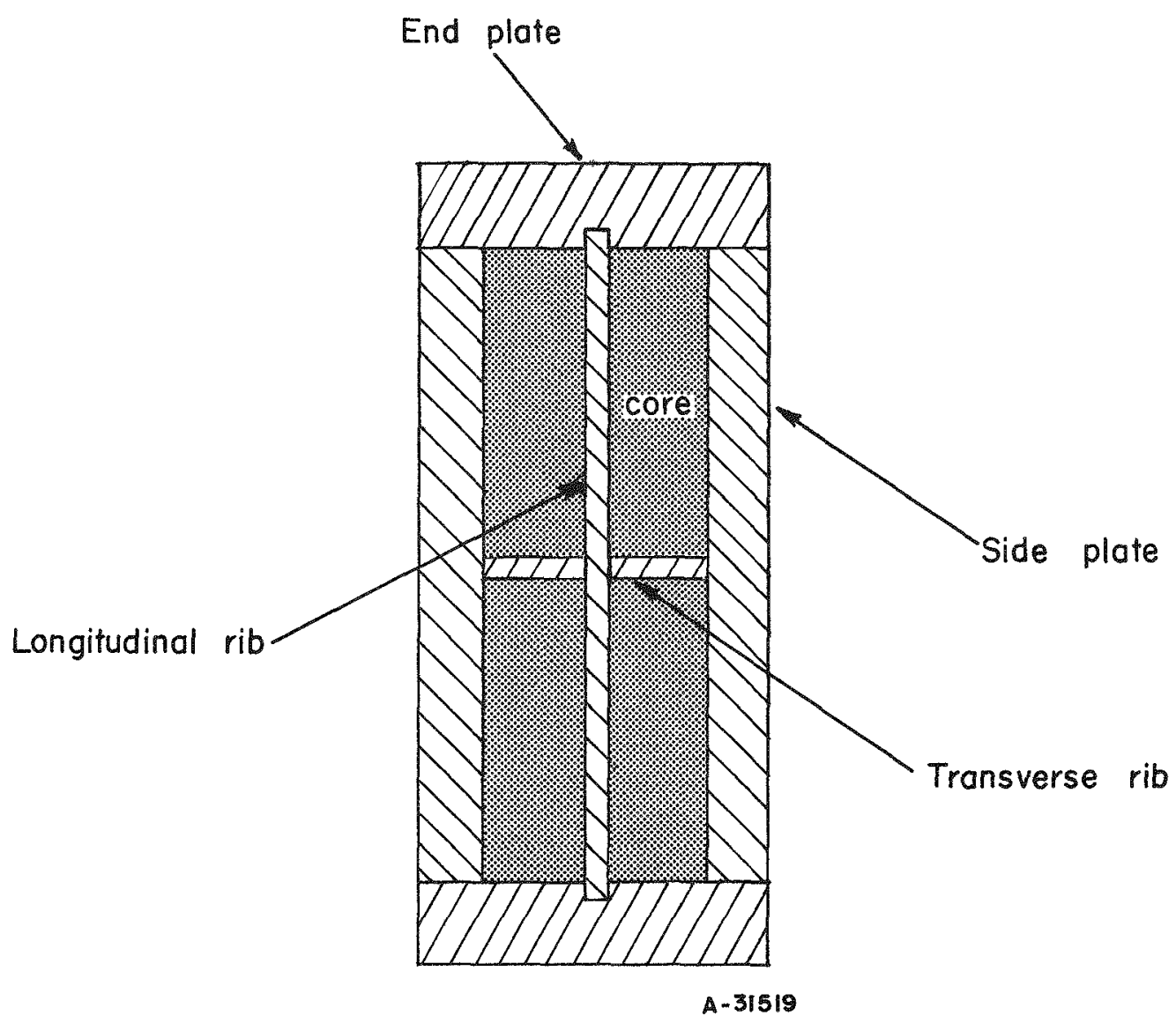

FIGURE 42. DRAWING SHOWING CONFIGURATION OF PIECE-COMPONENT PICTURE FRAMES USED IN PRELIMINAR Y EDGE-WELDED ELEMENTS (ACTUAL SIZE) 
TABLE 22, METALLOGRAPHIC EVALUATION OF PRELIMINARY EDGE-WELDED SPECIMENS HAVING PIECE-COMPONENT PICTURE FRAMES

All specimens were pressure bonded at 10,000 psi for $4 \mathrm{hr}$ at temperatures listed.

\begin{tabular}{|c|c|c|c|c|c|c|c|c|c|c|c|c|}
\hline \multirow[b]{3}{*}{ Specimen } & \multirow{3}{*}{$\begin{array}{l}\text { Pressure-Bonding } \\
\text { Temperature, F }\end{array}$} & \multicolumn{2}{|c|}{ Heat Treatment } & \multirow{2}{*}{\multicolumn{2}{|c|}{ Surface Preparation }} & \multirow{3}{*}{$\begin{array}{l}\text { Location } \\
\text { of Sample }\end{array}$} & \multicolumn{3}{|c|}{ Frame-to-Cover Bond Evaluation } & \multicolumn{3}{|c|}{ Rib-to-Rib Bond Evaluation } \\
\hline & & \multirow{2}{*}{$\begin{array}{c}\text { Temperature, } \\
\text { F }\end{array}$} & \multirow{2}{*}{$\begin{array}{c}\text { Time, } \\
\text { min }\end{array}$} & & & & Type A, & Type B, & Type C, & Type A, & Type B, & Type C, \\
\hline & & & & Cover Plates & Frames & & per cent & per cent & per cent & per cent & per cent & per cent \\
\hline$G-2-1$ & 1550 & 1850 & 5 & Abraded & Abraded & At rib & 90 & 9 & 1 & 90 & 10 & -- \\
\hline$G-2-2$ & 1550 & 1850 & 5 & Abraded & Abraded & At core & 80 & 20 & -- & $-\cdots$ & -- & -- \\
\hline$G-2-3$ & 1550 & 1850 & 5 & Abraded & Abraded & At rib & 80 & 19 & 1 & 80 & 19 & 1 \\
\hline$G-3-1$ & 1550 & None & -- & Abraded & Abraded & At core & 50 & 50 & -- & -- & -- & -- \\
\hline$G-3-2$ & 1550 & None & -- & Abraded & Abraded & At rib & 70 & 30 & -. & 70 & 30 & -- \\
\hline$G-3-3$ & 1550 & None & - & Abraded & Abraded & At core & 50 & 50 & $\ldots$ & -. & -- & -- \\
\hline$G-4-1$ & 1550 & 1850 & 5 & Abraded & Pickled & At rib & -- & 100 & -. & -- & 100 & $=$ \\
\hline$G-4-2$ & 1550 & 1850 & 5 & Abraded & Pickled & At core & 50 & 50 & -- & -- & -- & -- \\
\hline$G-5-1$ & 1750 & 1850 & 5 & Abraded & Pickled & At rib & 95 & 5 & -- & 100 & -- & -- \\
\hline$G-5-2$ & 1750 & 1850 & 5 & Abraded & Pickled & At core & 90 & 10 & -- & -- & -- & -- \\
\hline$G-6-1$ & 1750 & None & $-\ldots$ & Abraded & Pickled & At rib & -- & 90 & 10 & -- & 10 & 90 \\
\hline$G-6-2$ & 1750 & None & -- & Abraded & pickled & At core & 25 & 50 & 25 & -- & - & -- \\
\hline$G-8-1$ & 1750 & None & $\ldots$ & Pickled & pickled & At rib & -. & 20 & 80 & -. & -. & 100 \\
\hline$G-8-2$ & 1750 & None & -- & Pickled & Pickled & At core & 25 & 25 & 50 & -- & -- & -- \\
\hline$G-8-3$ & 1750 & None & -- & Pickled & Pickled & At rib & - & 80 & 20 & -- & -- & 100 \\
\hline
\end{tabular}


illustrated in Figure 43. The specimen with abraded cladding plates and pickled frame components which was bonded at $1750 \mathrm{~F}$ and heat treated showed good bonding also. However, the lower bonding temperature of $1550 \mathrm{~F}$, which produced satisfactory bonds between all belt-abraded components, is more desirable to minimize core-cladding reaction. The bond areas listed as Type B in Table 22 exhibited small spherical voids along the bond interfaces, indicating entrapped air or entrapped residual helium. No contamination of the bonds by graphite or $\mathrm{UO}_{2}$ was observed metallographically in this series of specimens. Also, radiographic examination of these specimens revealed no $\mathrm{UO}_{2}$ in the bond interfaces. Narrow zones of oxygen-rich Zircaloy were observed along some of the bond interfaces. The cause for these zones could not be isolated; possible causes are discussed in a subsequent section. The metallographic examination revealed no visible uranium-zirconium reaction zones in the specimens, but bands of oxygenrich Zircaloy were present in some areas around the cores in all specimens. These bands, which were about 0.001 to $0.002 \mathrm{in}$. wide, were most prevalent at the corners and edges of cores and in the specimens bonded at $1750 \mathrm{~F}$.

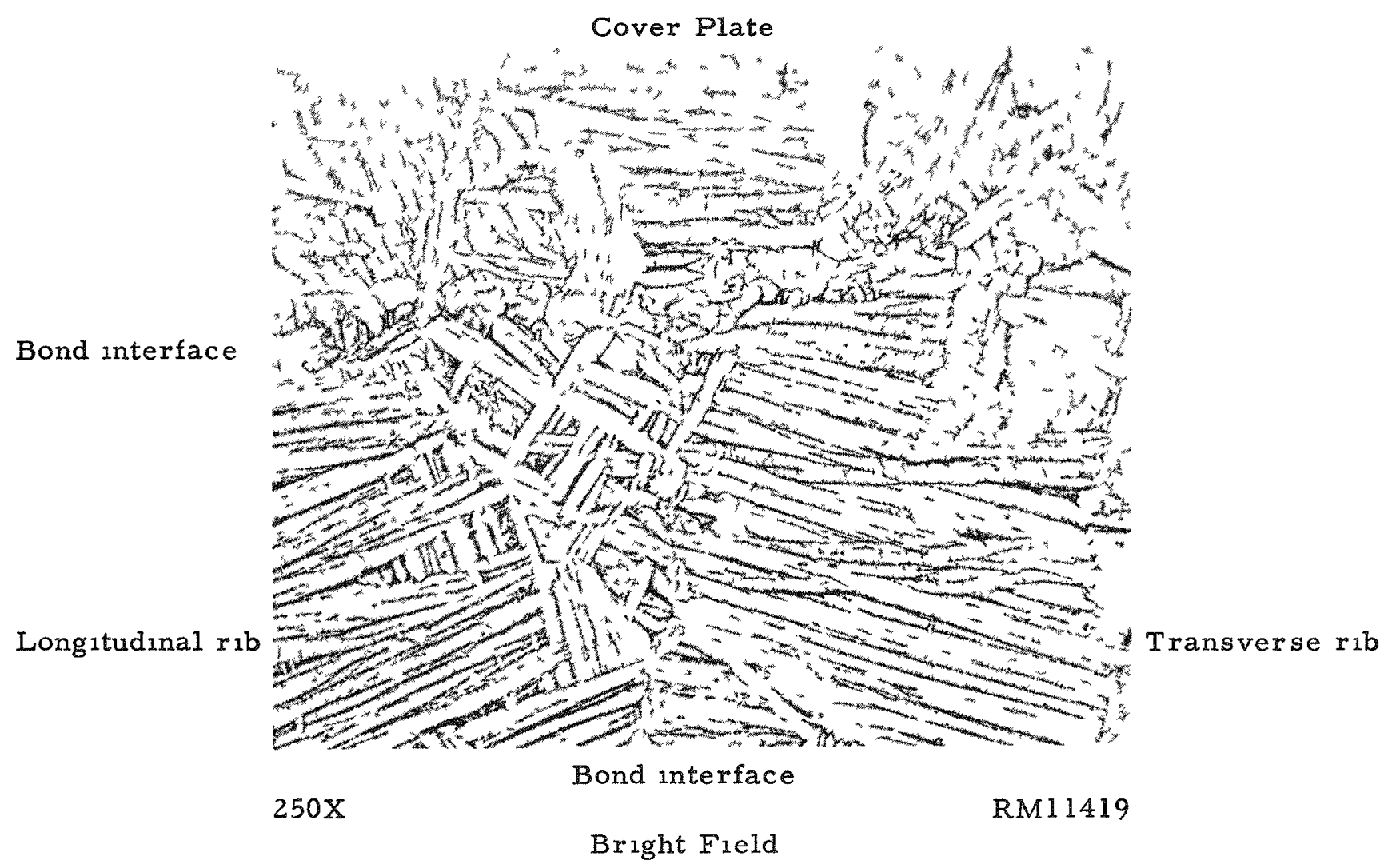

FIGURE 43. ZIRCALOY-TO-ZIRCALOY BONDS IN ELEMENT PREPARED UTILIZING EDGE WELDING AND A PIECE-COMPONENT PICTURE FRAME

Bonds between longltudinal $\mathrm{rib}$ and transverse $\mathrm{rib}$ and between the ribs and the cladding plate are shown in the photomicrograph. This element contained belt-abraded cladding components and was pressure bonded at $1550 \mathrm{~F}$ and $10,000 \mathrm{ps} 1$ for $4 \mathrm{hr}$ and heat treated at $1850 \mathrm{~F}$ for $5 \mathrm{~min}$ in a salt bath. 
Intercompartmental leakage, as revealed in the 700-psi leakage tests or burst tests, did not occur in any of the eight specimens. The results of the 700-psi intercompartmental leakage tests are contained in Table 23 in conjunction with the defectedcompartment corrosion tests in $680 \mathrm{~F}$ water. The results of these long-time corrosion tests indicated that core-cladding reaction apparently had not been sufficiently reduced in all areas by the thin graphite coatings on the cores, especially in the specimens bonded at $1750 \mathrm{~F}$. The specimens bonded at $1550 \mathrm{~F}$ exhibited extremely low growth after 4 months of corrosion testing. The cladding plates of all of the specimens appeared ductile during burst testing, as shown in Table 24. The ductility was improved somewhat by the $1850 \mathrm{~F}$ heat treatment.

The evaluations of these preliminary specimens thus demonstrated the feasibility of preparing leaktight edge-welded specimens with piece-component picture frames by gas-pressure bonding. Belt-abraded cladding components pressure bonded at $1550 \mathrm{~F}$ for $4 \mathrm{hr}$ at 10,000 psi produced the best results. The coatings of sprayed Aquadag in the amount of $1 \mathrm{mg}$ per in. 2 did not appear to result in contamination of the bond interfaces. Preparing the frame components several thousandths of an inch thicker than the cores minimized flow of the cladding plate and accompanying problems with bonding which had been encountered in the enveloped specimens made with punched frames that had undersized ribs following surface preparation by abrasion. The results indicated, however, that the thickness of the graphite coating on the cores should be increased in order to attempt to decrease the zones of oxygen-rich Zircaloy surrounding the cores, and that the technique by which the elements were sealed containing air would not produce optimum bonding.

\section{GAS-PRESSURE BONDING OF EDGE-WELDED ELEMENTS} FOR PROCESS DEVELOPMENT

A series of 39 large-scale elements was prepared utilizing edge welding of the components and piece-component picture frames in order to obtain a comprehensive evaluation of the procedures used. Preparation of these elements was based on the results of the earlier studies in this program. It was desired to determine any unsatisfactory properties of the elements prepared by this technique and to attempt to eliminate any such undesirable characteristics.

Preparation of Elements

The element design chosen for this study was similar to Design (a) shown in Figure 38 except that the notches were removed from the side plates and the size of the element was increased. It was determined later that to improve dimensional control it was necessary to eliminate the notches from the head plates also. The final design of the element, which consisted of 115 cladding components and cores, is shown in Figure 44. The approximate over-all size of the se elements was 15.0 by 4.3 in., with a thickness of 0.146 in., consisting of two 0.023-in. -thick cladding plates and a $0.100-$ in. - thick compartmented picture frame. A 0.25 by 2-in. extension was machined as an integral part of the top end plate of all except the first four elements of the series to provide a means for evacuating the specimens. Each picture frame consisted of twenty 
TABLE 23. RESUL TS OF INTERCOMPARTMENT AL LEAKAGE AND DEFECTED-COMPARTMENT CORROSION TESTS OF PRELIMINARY EDGE-WELDED SPECIMENS HAVING PIECE-COMPONENT PICTURE FRAMES

All specimens were pressure bonded at 10,000 psi for 4 hr at temperatures listed.

\begin{tabular}{|c|c|c|c|c|c|c|c|}
\hline \multirow[b]{2}{*}{ Specimen } & \multirow[b]{2}{*}{$\begin{array}{l}\text { Pressure-Bonding } \\
\text { Temperature, F }\end{array}$} & \multicolumn{2}{|c|}{ Heat Treatment } & \multirow[b]{2}{*}{$\begin{array}{l}\text { Total Time } \\
\text { on Test, days }\end{array}$} & \multirow{2}{*}{$\begin{array}{l}\text { Total } \\
\text { Growth, } \\
\text { mils }\end{array}$} & \multicolumn{2}{|c|}{$\begin{array}{l}\text { Intercompartmental } \\
\text { Leakage }\end{array}$} \\
\hline & & $\begin{array}{c}\text { Temperature, } \\
\text { F }\end{array}$ & $\begin{array}{c}\text { Time, } \\
\text { min }\end{array}$ & & & $\begin{array}{l}\text { Before } \\
\text { Corrosion }\end{array}$ & $\begin{array}{c}\text { After } \\
\text { Corrosion }\end{array}$ \\
\hline$G-1$ & 1550 & 1850 & 5 & 126 & 2 to 4 & None & None \\
\hline$G-3$ & 1550 & None & - & 119 & 2 & None & None \\
\hline$G-4$ & 1550 & 1850 & 5 & 112 & 0 & None & None \\
\hline$G-5$ & 1750 & 1850 & 5 & 119 & 4 & None & None \\
\hline$G-6$ & 1750 & None & $-\infty$ & 112 & 5 to 6 & None & None \\
\hline$G-7$ & 1750 & None & $-\cdots$ & 56 & 3 to 13 & None & None \\
\hline
\end{tabular}

TABLE 24. RESULTS OF BURST TESTS OF PRELIMINARY EDGE-WELDED SPECIMENS WITH PIECE-COMPONENT PICTURE FRAMES

All specimens were pressure bonded at 10,000 psi for $4 \mathrm{hr}$ at temperatures listed.

\begin{tabular}{|c|c|c|c|c|c|c|}
\hline \multirow[b]{3}{*}{ Specimen } & \multirow[b]{3}{*}{$\begin{array}{l}\text { Pressure-Bonding } \\
\text { Temperature, } F\end{array}$} & \multirow{2}{*}{\multicolumn{2}{|c|}{ Heat Treatment }} & \multicolumn{2}{|c|}{ Bursting Conditions } & \multirow[b]{3}{*}{$\begin{array}{c}\text { Intercompartmental } \\
\text { Leakage }\end{array}$} \\
\hline & & & & Maximum & & \\
\hline & & Temperature, F & $\begin{array}{c}\text { Time, } \\
\text { min }\end{array}$ & $\begin{array}{l}\text { Deflection, } \\
\text { mils }\end{array}$ & $\begin{array}{c}\text { Pressure, } \\
\text { psi }\end{array}$ & \\
\hline$G-2$ & 1550 & 1850 & 5 & 40 & 4300 & None \\
\hline$G-2$ & 1550 & 1850 & 5 & 40 & 1500 & None \\
\hline$G-3$ & 1550 & None & -. & 30 & 1200 & None \\
\hline$G-4$ & 1550 & 1850 & 5 & 52 & 2400 & None \\
\hline$G-5$ & 1750 & 1850 & 5 & 45 & 2500 & None \\
\hline$G-6$ & 1750 & None & - & 32 & 3000 & None \\
\hline$G-8$ & 1750 & None & - & 34 & 1000 & None \\
\hline$G-8$ & 1750 & None & -- & 32 & 1200 & None \\
\hline
\end{tabular}




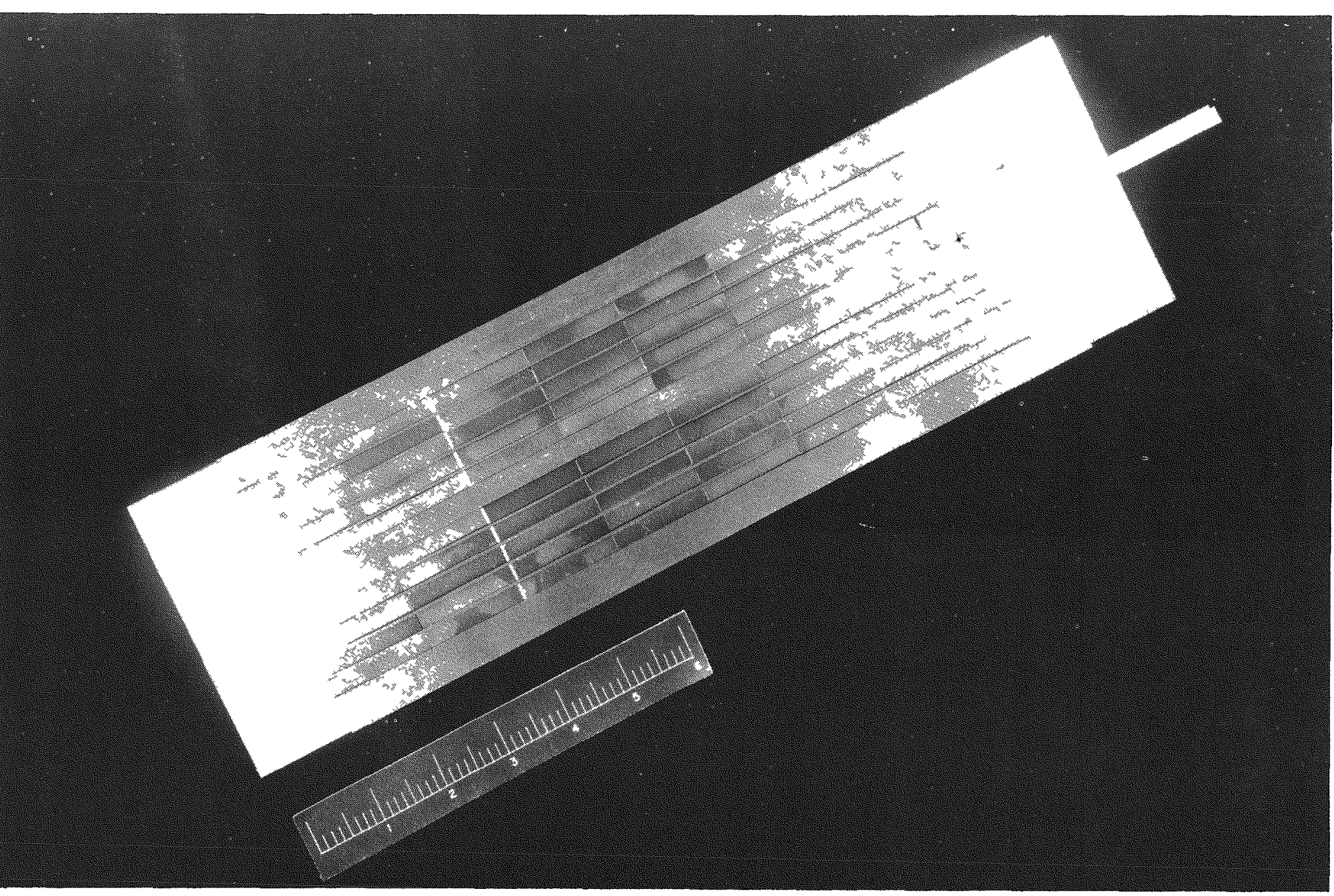

FIGURE 44. PHOTOGRAPH OF ASSEMBLED PIECE-COMPONENT PICTURE FRAME AND CORES

This picture-frame design was used to prepare pressure-bonded fuel elements for process development utilizing the edge-weldng techuque. The lateral vold space visible in some areas of the photograph was removed from the elements durung assembly by using side pressure and then clamping. 
0.25 by 3 -in. and ten 0.25 by 6 -in. fuel compartments, separated from each other by 0.040-in. -wide Zircaloy ribs. A 0.330-in.-wide strip of Zircaloy was placed longitudinally down the center of each picture frame to facilitate sectioning after bonding. All cladding components were surface finished by machine belt abrading using 60-grit silicon carbide belts operating at a speed of $2200 \mathrm{ft}$ per min with sulfonated oil coolant.

Each element contained 80 graphite-coated cores with dimensions of 0.100 by 0.250 by $1.500 \mathrm{in.} \mathrm{Coating} \mathrm{of} \mathrm{these} \mathrm{cores} \mathrm{was} \mathrm{accomplished} \mathrm{by} \mathrm{spraying} \mathrm{Aquadag,} \mathrm{a}$ suspension of graphite in water, onto the $\mathrm{UO}_{2}$ cores preheated to approximately $150 \mathrm{~F}$. The most adherent coatings were obtained when four passes per side were made with the spray gun. The feed was varied so that amounts of coating from 1 to $9 \mathrm{mg}$ of $\mathrm{graph}$ ite per in. 2 of core surface were applied. The coated cores required an outgassing treatment at $700 \mathrm{~F}$ in vacuum to remove all volatiles from the graphite coatings. Since the specimens bonded in the preliminary study showed that coatings of $1 \mathrm{mg}$ per in. 2 were not sufficient to minimize core-cladding reaction, the first several specimens in this series contained cores that were graphite coated with 2 to $3 \mathrm{mg}$ pei in. 2 of surface. When examination of these specimens revealed that this amount of coating did not completely prevent reaction, two specimens containing controlled amounts of coating from 1 to $9 \mathrm{mg}$ per in. 2 were prepared. Later elements contained cores coated with 5 to 6 mg per in. 2 of graphite. It was found during the latter part of the study that a buffing treatment after outgassing was necessary for coatings greater than $3 \mathrm{mg}$ per in. 2 in order to prevent contamination of the bonding surfaces. The cores for the last three specimens prepared were coated with $5.5 \mathrm{mg}$ per in. ${ }^{2}$ and were buffed to a high luster after coating by rubbing them firmly with a soft cloth; approximately $0.5 \mathrm{mg}$ per in. ${ }^{2}$ of the coating was removed from the cores by this operation.

Fusion edge welding was performed in a helium-atmosphere tank with the elements clamped between copper cooling blocks. In the initial elements of this series, a small opening was left in one end through which the helium could be evacuated. Air was then allowed to enter the elements and final sealing was done in air to attempt to prevent helium from being entrapped in the element. After the first few elements, two methods for evacuating and sealing elements containing a vacuum were developed and successfully employed. Both methods utilized a 0.25 by 2 -in. projection of the head plates at the top of each specimen as shown in Figure 44. A groove 0.015 in. deep and 0.060 in. wide was machined in the surface of the head plate to provide a channel for the evacuam tion of the entrapped gas. The elements were fusion welded in the helium-atmosphere tank on all sides so that only the end of the evacuation extensions remained open.

The first method of evacuation involved the use of a vacuum manifold and a resistance-welding machine. The evacuation extension of the edge-welded element was connected to a vacuum manifold by means of an adapter and a rubber hose. The specimen was evacuated to less than $1 \mu$ and then sealed by resistance-upset welding at approximately the center of the evacuation extension. The specimen was then disconnected from the vacuum manifold and the tip of the extension was sealed by helium-shielded arc welding to insure a gastight seal. In the second technique developed, the edgewelded element was placed in a vacuum chamber which contained a high-frequency induction coil. The element was held in a jig which positioned the tip of the extension so that it was in the center of the induction coil. The entire chamber was evacuated and the final seal of the specimen was accomplished by melting the tip of the extension by means of the induction coil. 
Although both techniques produced satisfactory results, the induction-sealing method was used on most of the specimens, since complete evacuation is more probable by this technique. In the resistance-upset-welding technique, as soon as evacuation begins, the cover plates are pressed tightly against the picture frame, and this restricts the passage of gas from one compartment to another during evacuation. The inductionsealing method, however, since the entire chamber is evacuated, tends to allow the cover plates and picture frame to remain slightly separated so that more complete evacuation can be accomplished.

The elements in this series were pressure bonded at $1550 \mathrm{~F}$ for $4 \mathrm{hr}$ at a pressure of $10,000 \mathrm{psi}$ in the large autoclave described earlier. Initial elements in the series were separated by Zircaloy shimming plates and were completely surrounded with tightly packed microquartz when loaded into the autoclave. Since the specimens loaded in this fashion showed poor dimensional control and contaminated cladding, the autoclave-loading technique was revised so that no insulating material would be near the specimens and the specimens would be given rigid structural support. This revised loading scheme is illustrated in Figure 45. To provide adequate jigging for the elements during bonding, a rectangular Zircaloy loading tube was constructed to very close tolerances and a Type 310 stainless steel tube was then fit closely around the Zircaloy tube to provide strength at the bonding temperature. This composite loading tube contained a bottom but the top was left open for loading. Four specimens, separated by Zircaloy spacers, were tightly packed into the loading tube for each run. Zircaloy chips were placed in the top of the loading tube to getter the atmosphere. Two half-cylinders of copper were machined to fill all void space in the inside of the autoclave furnace except for a 1-in. -wide slot in the center into which the loading tube containing the elements was placed. Pieces of copper bar were used to fill the remaining void space in the slot. The copper in the assembly served to minimize temperature gradients in the furnace.

After pressure bonding, each element was sectioned longitudinally through the center. One of the halves of each element was then heat treated for $5 \mathrm{~min}$ in a barium chloride salt bath at $1850 \mathrm{~F}$ and cooled between flattening dies in a stream of helium to prevent distortion and excessive oxidation. After bonding and after heat treatment, the specimens were vapor blasted and pickled in a hydrofluoric acid solution to clean the surfaces.

\section{Test Procedures}

Each pressure-bonded element was longitudinally sectioned prior to evaluation. One half of the element was evaluated in the as-bonded condition, while the remaining half was evaluated after being heat treated at $1850 \mathrm{~F}$ for $5 \mathrm{~min}$. In the tables of results presented, the suffixes $A$ and $B$ to the element number designate the as-bonded and the beta-heat-treated portions, respectively. The tests used for evaluation included visual examination, metallographic examination of bond quality and core-cladding reaction, peel tests of bonds, intercompartmental-leakage tests, burst tests of compartments, corrosion tests of purposely defected compartments, and chemical analyses. Tests were conducted in essentially the same manner as described in the section on pressure bonding of elements in containers for process development. In the leakage, corrosion, and burst tests, the diameter of the drilled holes was changed from 0.005 to $0.040 \mathrm{in}$. and the pressure used in the leakage tests was increased from 200 to 700 psi. 


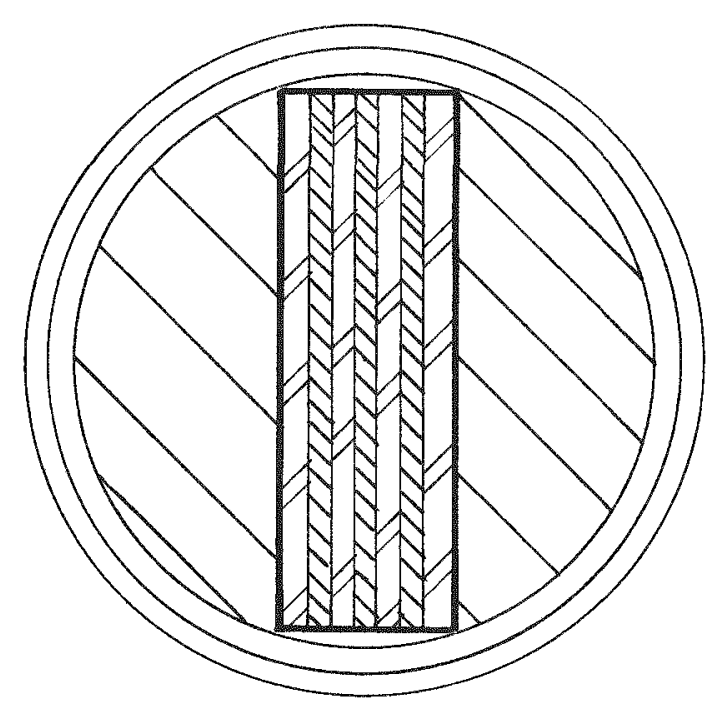

(a) Cross Section of Autoclave Looding Assembly
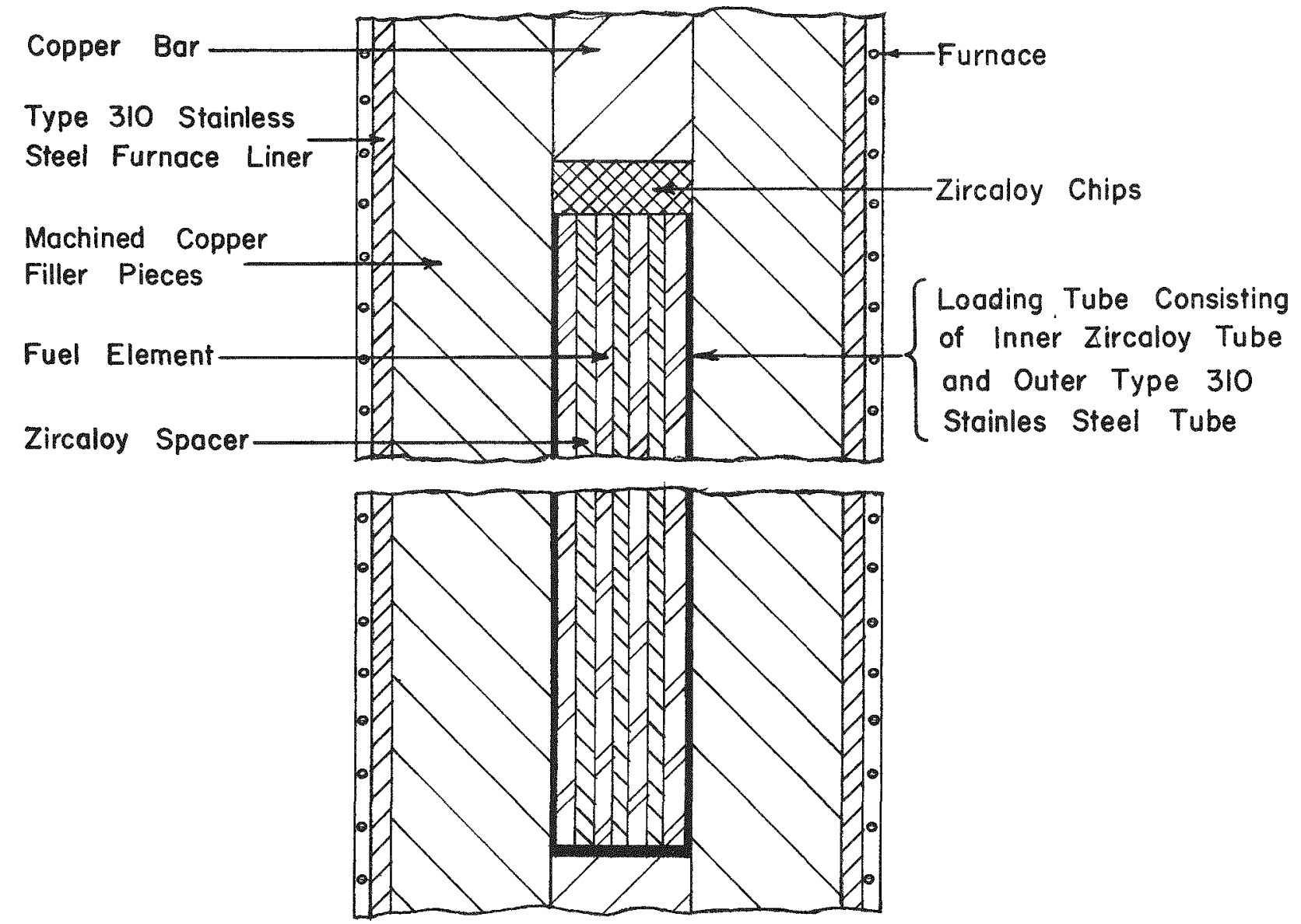

(b) Longitudinal Section of Autoclave Loading Assembly A-31520

FIGURE 45. SECTIONAL DRAWINGS OF AUTOCLAVE LOADING ASSEMBLY USED TO GAS-PRESSURE BOND EDGE-WELDED ELEMENTS FOR PROCESS DEVEIOPMENT STUDY 
Most of the elements in this series were burst tested in two compartments of the lower portion of the element; the remaining portions were tested for intercompartmental leakage and defected-compartment corrosion behavior. Metallographic and peel-test specimens were usually obtained from the lower portion of the element after burst testing, but other portions of the elements were also periodically checked by these techniques. In later elements in the series, the importance of the burst test to reveal weak bonds became apparent, and additional compartments from other sections of the elements were tested in this manner.

Test Results

\section{General Evaluation}

Earlier edge-welded elements in this series exhibited a number of uniatisfactory properties which were eliminated in later specimens. The problems encountered in these elements were wrinkling of the cladding, warping and bowing of the elements, contamination of the cladding, entrapped gas in the elements, and weak bonds in elements which contained thick graphite coatings. The first two problems listed are discussed in the section on general evaluation, while the third and fourth are discussed in the section on metallographic examination. The problem of weak bonds is discussed in connection with both metallographic and burst-test evaluations.

Initial edge-welded specimens utilized the notched-head-plate design with the thickness of the ribs being greater than that of the cores by 0.004 in. It was observed after bonding that the cladding plates contained wrinkles in areas over the longitudinal ribs and that the elements had increased in thickness up to 0.020 in. in these areas. Analysis of this phenomenon indicated that it was caused by the flow of excess cladding plate material in a lateral direction which built up along the slightly elevated longitudinal ribs. It was determined that dimensional tolerances needed for machining the notches in the head plates caused excessive lateral void space in the assembled elements. This allowed the elements during pressure bonding to decrease in width in the core areas while retaining the original width dimension across the solid head plates. This effect caused poor dimensional control and resulted in excess cover plate material over the cores. Since the edges of the cladding plates were welded to the side plates, they were forced to flow inward as the lateral void space was filled, thereby causing wrinkling of the cladding plates. This wrinkling occurred at the location of the oversize longitudinal ribs since these points offered the greatest resistance to the lateral flow of the cladding material. This problem was not encountered in the longitudinal direction since most of the void space in this direction was removed by placing small shims at the top of each row of cores.

Based on the above analysis, it was necessary to alter the design of the piececomponent picture frames. The notches were removed from the head plates and the width of the head plates was reduced to coincide exactly with that of the assembled cores and ribs with no void-space allowances. With the notches in the head plates removed, the cores and frame components were free to move laterally and it was possible to remove almost all of the void space during assembly. With this modified design, it was considered desirable to place a 0.040-in. -thick shim, not exceeding the width of the cores, at each end of each row of cores to form a "pieced notch". This technique made 
allowances for cores which were oversize in length and which might otherwise have held the headplate away from the ends of the longitudinal ribs, thereby preventing bonding from occurring. Additional 0,005-in. -thick shims were placed at the top end of a row of cores if needed to fill longitudinal void space. The thickness of the picture-frame components was also reduced to the exact thickness of the cores.

Elements containing picture frames of the modified piece-component design were prepared and pressure bonded. Examination of these specimens showed that the coverplate wrinkling problem and dimensional-control problem had been eliminated. One of these pressure-bonded elements is shown before sectioning in Figure 46. It was also found in the intercompartmental leakage tests, discussed later, that leaktight compartments could be formed using this picture-frame design.

Slight warpage and longitudinal camber occurred during the pressure bonding of the initial elements. As described earlier, later elements were bonded using a different autoclave-loading technique. The incorporation of the stainless steel loading tube provided structural support for the elements during bonding and virtually eliminated longitudinal camber and warpage in subsequent specimens. Slight warpage of some of the elements which had been sealed by induction welding still occurred, however, due to the small bulbs of flowed metal that were formed on the ends of the extensions during the induction sealing. When these elements were placed side by side in the loading envelope, the bulbs pressed against the extensions of the adjacent elements producing a sufficient force to cause warping at bonding temperatures. The use of thicker shim material between elements in the loading tube prevented contact of the extensions and eliminated the difficulty. This problem was not encountered in the elements sealed by the resistance-upset welding technique.

In these elements, a problem was experienced with the excessive flow of the cladding plates into void areas in the picture frame due to chipped cores or excessive assembly tolerances in the longitudinal direction. This resulted in undesirable cladding depressions, and, in extreme cases, in thinning of the cladding. When large void spaces were present between two cores not separated by a Zircaloy rib, the cladding was thinned to rupture, as shown in Figure 47.

Void space due to assembly tolerances in the longitudinal direction was minimized by placing a sufficient number of the 0.005-in.-thick shims at the end of the row of cores to fill the space. Void space less than $0.005 \mathrm{in}$. in one location did not result in any depression, even when located between two cores not separated by a rib. Void space in the picture frame due to chipped cores can be eliminated only by selection of unchipped cores for assembly. It would be desirable to determine the maximum amount of void space of both types which is permissible in the frame assembly of elements to be pressure bonded, and also to determine a method of minimizing this effect in a manner such that elimination of void space is not as critical. These aspects are being investigated in a newly initiated study. 


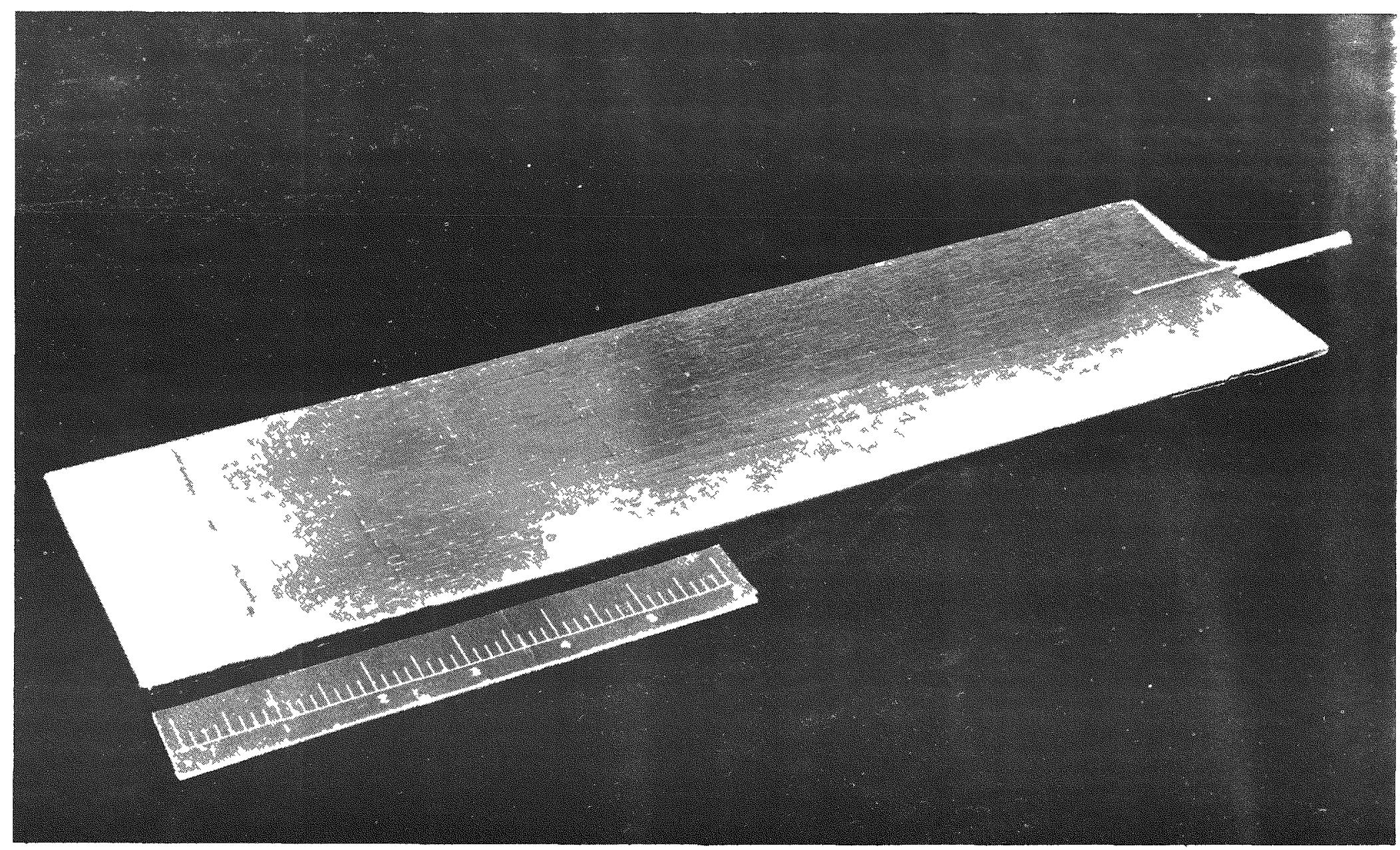

FIGURE 46. PHOTOGRAPH OF EDGE-WELDED FUEL ELEMENT PRESSURE BONDED AT 1550 F AND 10,000 PSI FOR 4 HR

The element was prepared using a piece-component picture frame of the improved design shown in Figure 44. 


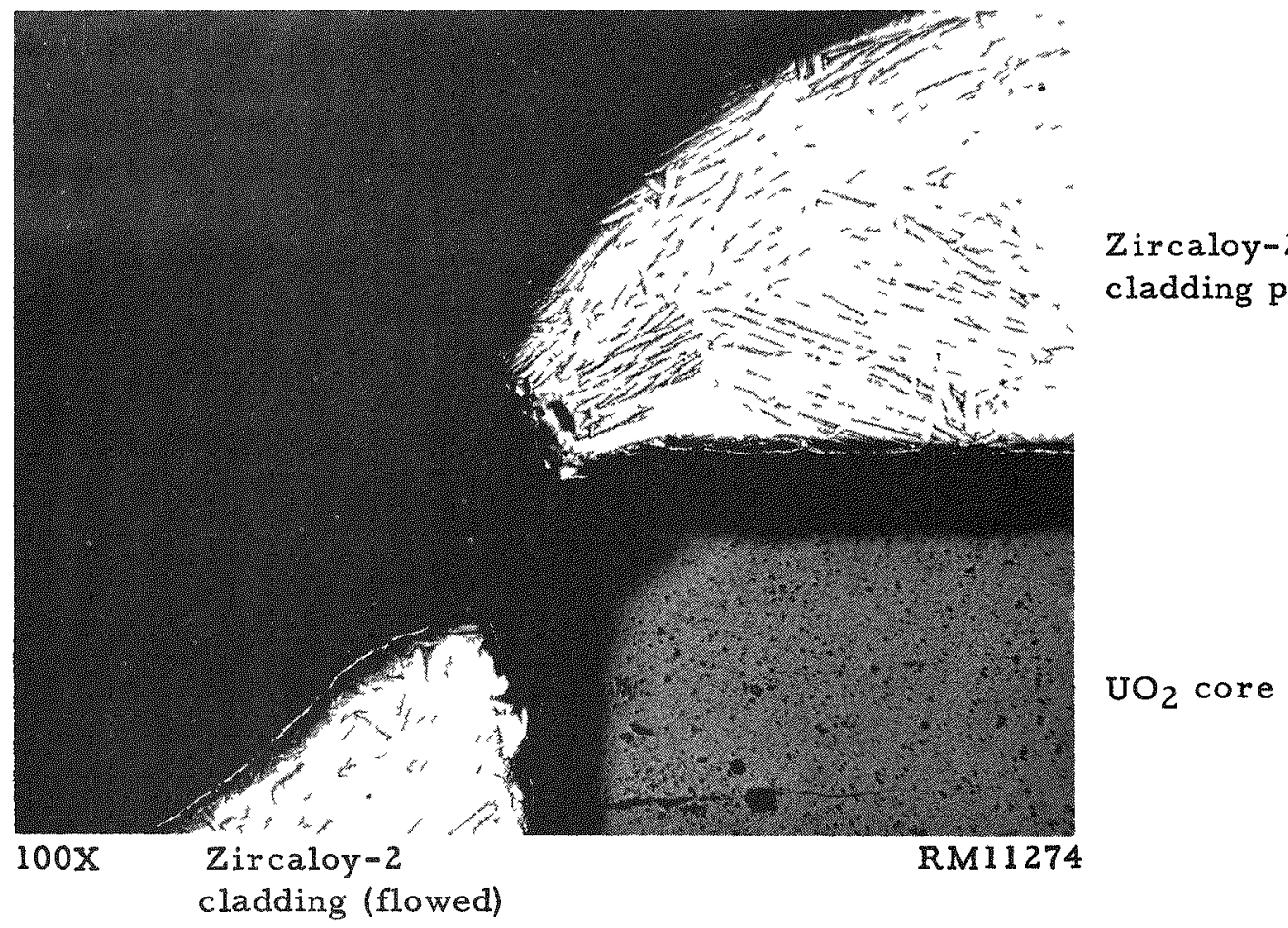

FIGURE 47. AREA OF AN ELEMENT IN WHICH THE CLADDING PLATE FLOWED EXCESSIVELY DURING PRESSURE BONDING INTO A LARGE VOID SPACE BETWEEN TWO CORES CAUSED BY A CHIP IN ONE OF THE CORES

The excessive flow produced thinning and, eventually, rupture of the cladding plate.

\section{Analyses of Cladding}

Analyses of the hydrogen, nitrogen, and oxygen contents of portions of the Zircaloy cladding removed from some of the elements were made in order to detect contamination of the Zircaloy during bonding. Samples of the cladding were also analyzed after the additional heat treatment at $1850 \mathrm{~F}$ for $5 \mathrm{~min}$. The results of these determinations are in Table 25.

Zircaloy shimming plates accompanied the elements in all runs in the autoclave. After bonding, these plates were bend tested to determine their relative ductility, and, in some cases, a portion was analyzed for gas content. Although embrittlement of the Zircaloy cladding had not been encountered in the preliminary specimens, it was found that the shimming plates accompanying the first few large-scale elements were very brittle. Burst tests of these elements, as discussed later, revealed rather brittle behavior of the cladding plates. Vacuum-fusion analyses of cladding removed from one of the se elements $(T-4 B-E$ and $T-4 B-C$ in Table 25) showed high hydrogen contents of 120 to $140 \mathrm{ppm}$ and an oxygen content which compared to the base material before bonding. The major difference between the preparation of the large-scale elements and the preliminary elements was that the large elements were bonded in a different, larger autoclave. Investigation showed that this autoclave contained moisture, especially in the insulating material, which acted as a desiccant. To eliminate the moisture, the 
TABLE 25. RESULTS OF GAS-CONTENT ANALYSES OF ZIRCALOY CLADDING FROM ELEMENTS PRESSURE BONDED UTILIZING THE EDGE-WELDING TECHNIQUE

Elements were bonded $4 \mathrm{hr}$ at $1550 \mathrm{~F}$ and $10,000 \mathrm{psi}$.

\begin{tabular}{|c|c|c|c|c|c|c|c|}
\hline \multirow[b]{3}{*}{ Specimen } & \multicolumn{3}{|c|}{ Heat Treatment } & \multirow[b]{3}{*}{ Location } & \multirow{2}{*}{\multicolumn{2}{|c|}{$\begin{array}{l}\text { Vacuum-Fusion Analysis } \\
\text { of Cladding, } \mathrm{ppm} \\
\end{array}$}} & \multirow{3}{*}{$\begin{array}{l}\text { Kjeldahl Analysis } \\
\text { for Nitrogen, } \mathrm{ppm}\end{array}$} \\
\hline & \multirow[b]{2}{*}{ Temperature, $\mathrm{F}$} & & \multirow{2}{*}{$\begin{array}{l}\text { Time, } \\
\text { min }\end{array}$} & & & & \\
\hline & & F & & & Oxygen & Hydrogen & \\
\hline$S-1^{(a)}$ & -- & & -- & Claddıng plate & 1300 & 9 & - \\
\hline$s-2(a)$ & -- & & - & Cladding plate & 2200 & 36 & -- \\
\hline$T-4 B-E$ & 1850 & & 5 & End & -- & 120 & -- \\
\hline$T-4 B-C$ & 1850 & & 5 & $\begin{array}{l}\text { Cladding plate } \\
\text { over core }\end{array}$ & 1000 & 140 & -- \\
\hline$T-6 A-C$ & & None & & $\begin{array}{l}\text { Cladding plate } \\
\text { over core }\end{array}$ & 670 & 11 & -- \\
\hline$T-6 B-C$ & 1850 & & 5 & $\begin{array}{l}\text { Cladding plate } \\
\text { over core }\end{array}$ & 1600 & 40 & $\cdots$ \\
\hline$T-8 A-E$ & & None & & End & - & 19 & $-\infty$ \\
\hline$T-8 \mathrm{~A}-\mathrm{C}$ & & None & & $\begin{array}{l}\text { Cladding plate } \\
\text { over core }\end{array}$ & 1070 & 18 & 50 \\
\hline$T-8 B-C$ & 1850 & & 5 & $\begin{array}{l}\text { Cladding plate } \\
\text { over core }\end{array}$ & 1600 & 32 & 60 \\
\hline$C-8$ & & None & & $\begin{array}{l}\text { Zircaloy shim run } \\
\text { with } \mathrm{T}-8 \mathrm{in} \\
\text { autoclave }\end{array}$ & 1600 & 38 & 60 \\
\hline$T-14 A-C$ & & None & & $\begin{array}{l}\text { Cladding plate } \\
\text { over core }\end{array}$ & 1200 & 50 & $-\infty$ \\
\hline$T-14 A-R$ & & None & & $\mathrm{R} \mathbf{b}$ & 1400 & 55 & -- \\
\hline$T-14 B-C$ & 1850 & & 5 & $\begin{array}{l}\text { Cladding plate } \\
\text { over core }\end{array}$ & 1800 & 62 & - \\
\hline$T-15 A-C$ & & None & & $\begin{array}{l}\text { Cladding plate } \\
\text { over core }\end{array}$ & 1300 & 27 & \\
\hline $\mathrm{T}-15 \mathrm{~B}-\mathrm{E}$ & 1850 & & 5 & End & 1500 & 33 & \\
\hline$T-15 B-R$ & 1850 & & 5 & $\mathrm{R} d \mathrm{~b}$ & 1500 & 68 & \\
\hline$T-15 B-C$ & 1850 & & 5 & $\begin{array}{l}\text { Cladding plate } \\
\text { over core }\end{array}$ & -- & 71 & \\
\hline
\end{tabular}

(a) As-received material, not bonded. 
autoclave was emptied and dried, and all of its contents were baked completely dry before replacing them. Afterwards, the autoclave was sealed from external moisture between runs. In addition, the method of loading the elements in the autoclave was modified, as discussed previously, in order to minimize contamination of the Zircaloy and warpage of the elements. In this method, the elements were loaded along with Zircaloy shim plates and Zircaloy chips into a stainless steel loading tube with an internal Zircaloy liner. The auxiliary Zircaloy in this loading as sembly gettered the autoclave gas, and the loading tube served to protect the elements from convective currents of gas which had not been gettered.

These modifications of the pressure-bonding process eliminated embrittlement of the cladding as evidenced by bend and burst-tests, and reduced the hydrogen content, as shown in Table 25. It can be noted in the table that the amount of hydrogen in the Zircaloy was increased during the 5 -min heat treatment in an $1850 \mathrm{~F}$ barium chloride salt bath. It is believed that this increase can be avoided by utilizing a degassed salt bath under an inert-atmosphere blanket.

Intercompartmental-Leakage Tests and Corrosion Tests of Purposely Defected Compartments

Intercompartmental-leakage tests were conducted as described previously by defecting the compartments of an element with 0.040-in.-diameter holes, pressurizing the compartments successively with 700 psi of helium, and detecting any passage of gas to other compartments. After the pressure tests, the elements were subjected to defected-compartment corrosion tests in $680 \mathrm{~F}$ water. Periodically, the elements were removed from corrosion testing and measured for growth in thickness. They were again pressurized to detect intercompartmental leakage, and then were exposed to further corrosion testing. About 175 compartments were tested for leakage in these elements.

There was no evidence of intercommunication between any of the compartments before corrosion testing. After corrosion exposure, three of the elements which contained cores with thick graphite coatings that were not buffed exhibited intercompartmental leakage. This leakage was apparently associated with preferential, severe corrosion of bonds contaminated by graphite from the cores. This bond-contamination problem and its elimination in later elements by buffing the coated cores is discussed in connection with the burst-test and metallographic results. The corrosion tests of the defected compartments produced no swelling of the elements for exposure times up to 105 days, demonstrating that the graphite coatings had minimized core-cladding reaction to an acceptable level. The results of the se leakage and corrosion tests are listed in Table 26. Except in areas of some of the elements which had not been sufficiently cleaned, during corrosion exposure the Zircaloy cladding of the elements formed the shiny black film characteristic of corrosion-resistant Zircaloy. An element with purposely defected compartments which was corrosion tested for 70 days in $680 \mathrm{~F}$ water is shown in Figure 48. 
TABLE 26. RESULTS OF CORROSION TESTS AND INTERCOMPARTMENT AL-LEAKAGE TESTS OF GAS-PRESSURE-BONDED ELEMENTS PREPARED UTILIZING EDGE WELDING AND PIECE-COMPONENT PICTURE FRAMES

Elements were bonded $4 \mathrm{hr}$ at $1550 \mathrm{~F}$ and $10,000 \mathrm{psi}$

\begin{tabular}{|c|c|c|c|c|c|c|c|c|}
\hline \multirow[b]{3}{*}{ Specimen } & \multirow{2}{*}{\multicolumn{2}{|c|}{ Heat Treatment }} & \multirow[b]{3}{*}{$\begin{array}{l}\text { Amount of Graphite } \\
\text { coating, mg per in. } 2\end{array}$} & \multirow[b]{3}{*}{$\begin{array}{c}\text { Number of Compartments } \\
\text { Tested }\end{array}$} & \multicolumn{2}{|c|}{ Results of Corrosion Tests } & \multirow{2}{*}{\multicolumn{2}{|c|}{$\begin{array}{c}\text { Evıdence of Intercompart - } \\
\text { mental Leakage }\end{array}$}} \\
\hline & & & & & & Total Increase in & & \\
\hline & $\begin{array}{c}\text { Temperature, } \\
\text { F }\end{array}$ & $\begin{array}{l}\text { Time, } \\
\text { min }\end{array}$ & & & $\begin{array}{l}\text { Total Exposure } \\
\text { Time, days }\end{array}$ & $\begin{array}{c}\text { Thickness of Element, } \\
\text { mils }\end{array}$ & $\begin{array}{l}\text { Before } \\
\text { Corrosion }\end{array}$ & $\begin{array}{c}\text { After } \\
\text { Corrosion }\end{array}$ \\
\hline$T-1 B$ & 1850 & 5 & 2 & 22 & 105 & Negligible & None & None \\
\hline$T-4 B$ & 1850 & 5 & 3 & 22 & 98 & Negligible & None & None \\
\hline $\mathrm{T}-6 \mathrm{~A}$ & \multicolumn{2}{|c|}{ None } & 3 & 10 & 77 & Negligible & None & None \\
\hline$T-8 A$ & \multicolumn{2}{|c|}{ None } & 3 & 10 & 77 & Negligible & None & None \\
\hline $\mathrm{T}-11 \mathrm{~A}$ & \multicolumn{2}{|c|}{ None } & 3 & 10 & 70 & Negligible & None & None \\
\hline$T-11 B$ & 1850 & 5 & 3 & 10 & 70 & Negligıble & None & None \\
\hline$T-13 A$ & \multicolumn{2}{|c|}{ None } & 5 to 9 & 10 & 70 & Neghingle & None & None \\
\hline$T-13 B$ & 1850 & 5 & 1 to 5 & 10 & 70 & Negligible & None & None \\
\hline$T-14 \mathrm{~A}$ & \multicolumn{2}{|c|}{ None } & 3 & 5 & 70 & Negligible & None & None \\
\hline$T-14 B$ & 1850 & 5 & 3 & 5 & 70 & Negligible & None & None \\
\hline $\mathrm{T}-15 \mathrm{~A}$ & \multicolumn{2}{|c|}{ None } & 1 to 5 & 10 & 70 & Negligible & None & Yes \\
\hline$T-15 B$ & 1850 & 5 & 5 to 9 & 10 & 70 & Negligible & None & None \\
\hline$T-16 \mathrm{~A}$ & \multicolumn{2}{|c|}{ None } & 5 & 5 & 70 & Negligible & None & Yes \\
\hline$T-16 B$ & 1850 & 5 & 5 & 5 & 70 & Negligible & None & None \\
\hline$T-23 B$ & 1850 & 5 & 5 & 10 & 70 & Negligible & None & Yes \\
\hline$T-28 \mathrm{~A}$ & \multicolumn{2}{|c|}{ None } & 5 & 10 & 70 & Negligible & None & None \\
\hline$T-37 \mathrm{~A}$ & \multicolumn{2}{|c|}{ None } & 5 (buffed) & 5 & 63 & Negligible & None & None \\
\hline$T-37 \mathrm{~B}$ & 1850 & 5 & 5 (buffed) & 10 & 63 & Negligible & None & None \\
\hline
\end{tabular}




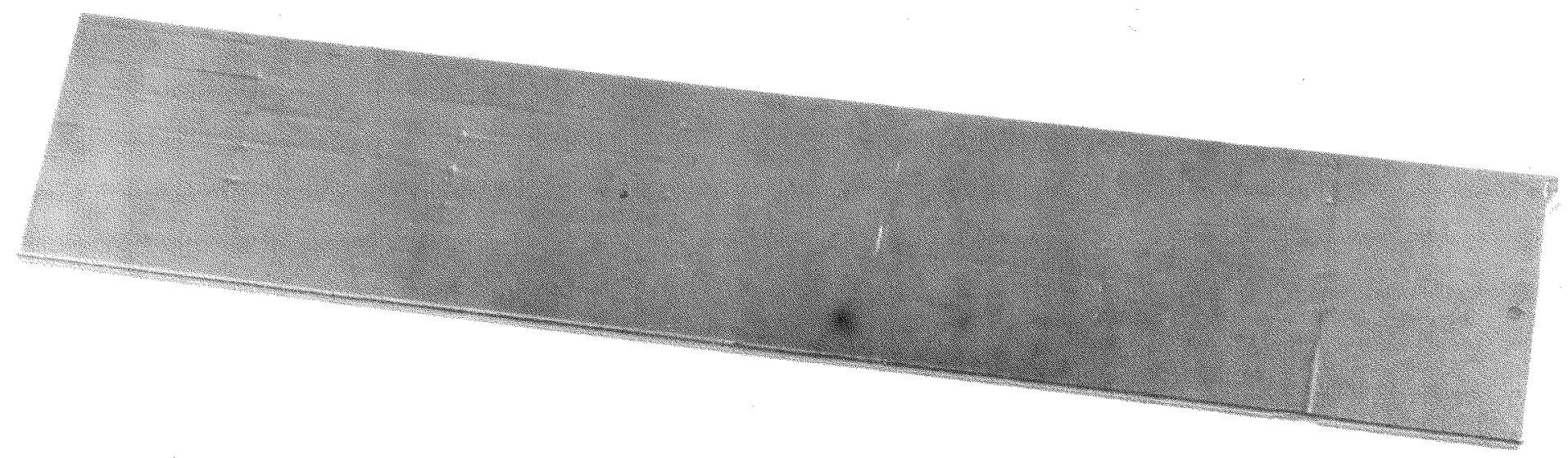

FIGURE 48. PRESSURE-BONDED ELEMENT WITH PURPOSELY DEFECTED COMPARTMENTS CORROSION TESTED FOR 70 DAYS IN 680 F WATER

This element was prepared utilizing the edge-welding technique and a piece-component picture frame, and was pressure bonded at $1550 \mathrm{~F}$ and $10,000 \mathrm{psi}$ for $4 \mathrm{hr}$ and heat treated at $1850 \mathrm{~F}$ for $5 \mathrm{~min}$. The element showed no swelling during corrosion exposure and developed a shiny black film typical of corrosion-resistant Zircaloy. 
Burst Tests of Compartments

Compartments in all of the elements evaluated were subjected to burst tests, conducted as described in a previous section. In this test, the purposely defected compartments were subjected internally to increasing pressure until rupture of the cladding plate or failure of a bond interface occurred, and the pressure and deflection resulting in failure were measured. Figure 49 shows the as-bonded portion of an element which failed through the cladding in a normal manner.

Burst tests of compartments in the elements which were bonded before moisture was eliminated from the autoclave and the loading method was modified, as discussed in the section on chemical analyses, produced only small amounts of deflection on the cladding before rupture occurred. In Table 27, which contains the results of all of the burst tests, this brittle behavior of the cladding can be noted for Specimens $T-1 B$ and $\mathrm{T}-4 \mathrm{~B}$, which were bonded before the discussed modifications were made. Bend tests confirmed that embrittlement of the Zircaloy cladding had occurred and chemical analyses revealed the high hydrogen content of the cladding as described previously. Results of the elements following Specimen $\mathrm{T}-4 \mathrm{~B}$, as shown in Table 27, revealed improved ductility of the cladding due to the described modifications which were made at that time. Bend tests and chemical analyses, discussed earlier, substantiated these results.

The most frequent and serious problem encountered in these elements was the relatively weak bonds in some areas of some of the elements which failed at high pressures during burst testing. This type of failure, instead of rupture of the claddingplate material itself, resulted in intercompartmental leakage. It can be noted in Table 27 that no bond failure occurred in the burst tests below 1000 psi, and that in most cases the failure resulted well above 2000 psi. Thus, the bond failures during burst testing were evidence of weak bonds and indicate that originally there had not been a complete lack of bonding or voids permitting leakage between compartments. Most of the burst-test bond failures were encountered in elements tested in the as-pressurebonded condition; a smaller number of elements which had received the 5-min heat treatment at $1850 \mathrm{~F}$ after bonding exhibited bond failure. Thus, the additional heat treatment appeared to improve bond strength, but did not eliminate the problem of contaminated bonds. Results of peel tests of bonds substantiated these burst-test results.

In order to eliminate the bond failures as revealed in burst testing, it was necessary to determine the cause for the weak bonds. The burst-test results were correlated with metallographic examination of bonds in good and failed areas. In addition, electron microscopy and $\mathrm{X}$-ray diffraction were utilized to identify the cause of the weak bonds observed during burst testing. The results of these studies, which are discussed in a later section on metallographic examination, indicated that the weak bonds were caused by contamination of the bond interfaces with graphite from the graphitecoated cores. It can be noted in Table 27 that bond failures were not encountered until the amount of graphite coating on the cores was increased above $5 \mathrm{mg}$ per in. ${ }^{2}$, indicating that the failures were associated with the thicker graphite coatings, which had been observed to flake and dust more readily than the thinner coatings.

To obtain a comparison with the burst-test behavior and metallographic appearances of the elements revealing bond failures during burst testing, two elements were prepared with bonding surfaces which were intentionally smeared with a very thin layer 

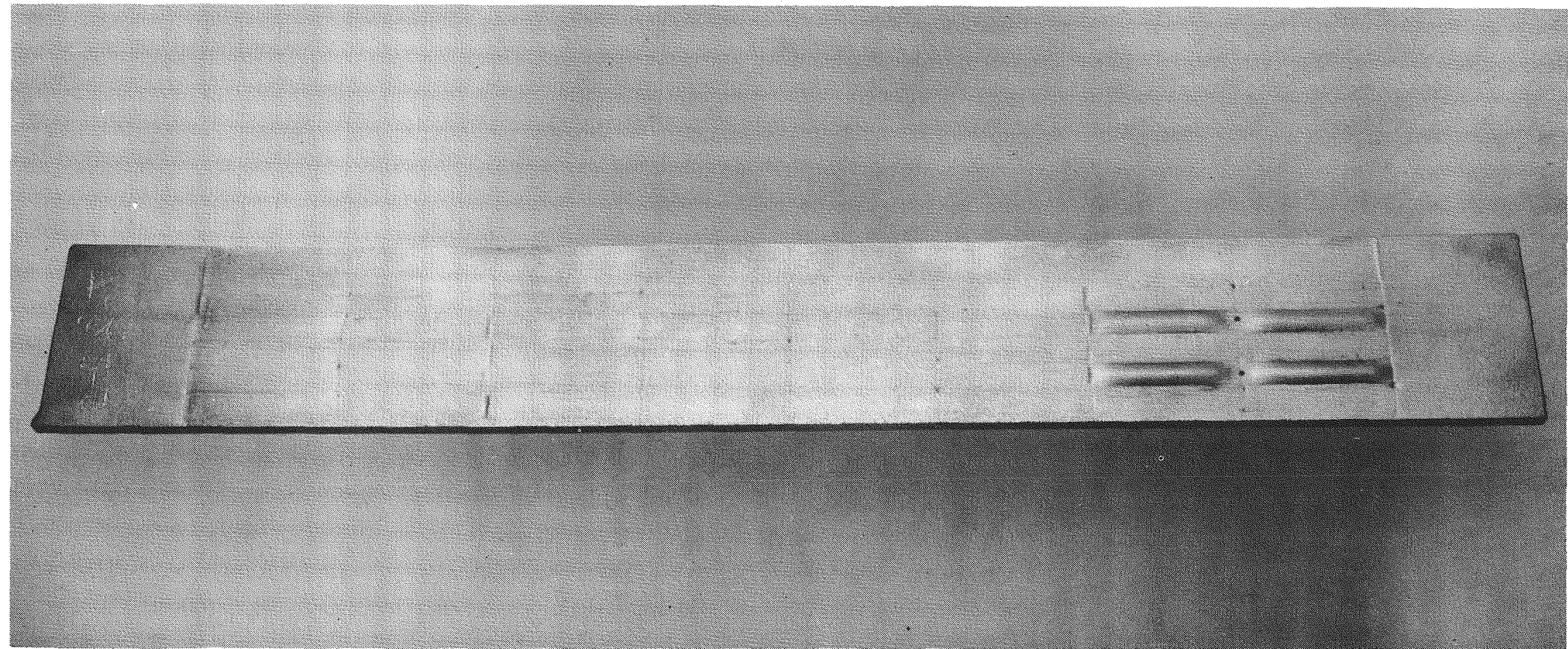

$5 / 8 \mathrm{X}$

N55889

FIGURE 49. PHOTOGRAPH OF AS-PRESSURE-BONDED PORTION OF ELEMENT WHICH FAILED THROUGH THE CLADDING IN A NORMAL MANNER DURING BURST TESTING

This element was prepared utilizing the edge-welding technique and a piece-component picture frame and was gasmpressure bond ed at $1550 \mathrm{~F}$ and $10,000 \mathrm{ps}$ for $4 \mathrm{hr}$. 
TABLE 27. RESULTS OF BURST TESTS OF GAS-PRESSURE-BONDED ELEMENTS PREPARED UTILIZING EDGE WELDING AND PIECE-COMPONENT PICTURE FRAMES

Elements were bonded $4 \mathrm{hr}$ at $1550 \mathrm{~F}$ and $10,000 \mathrm{psi}$.

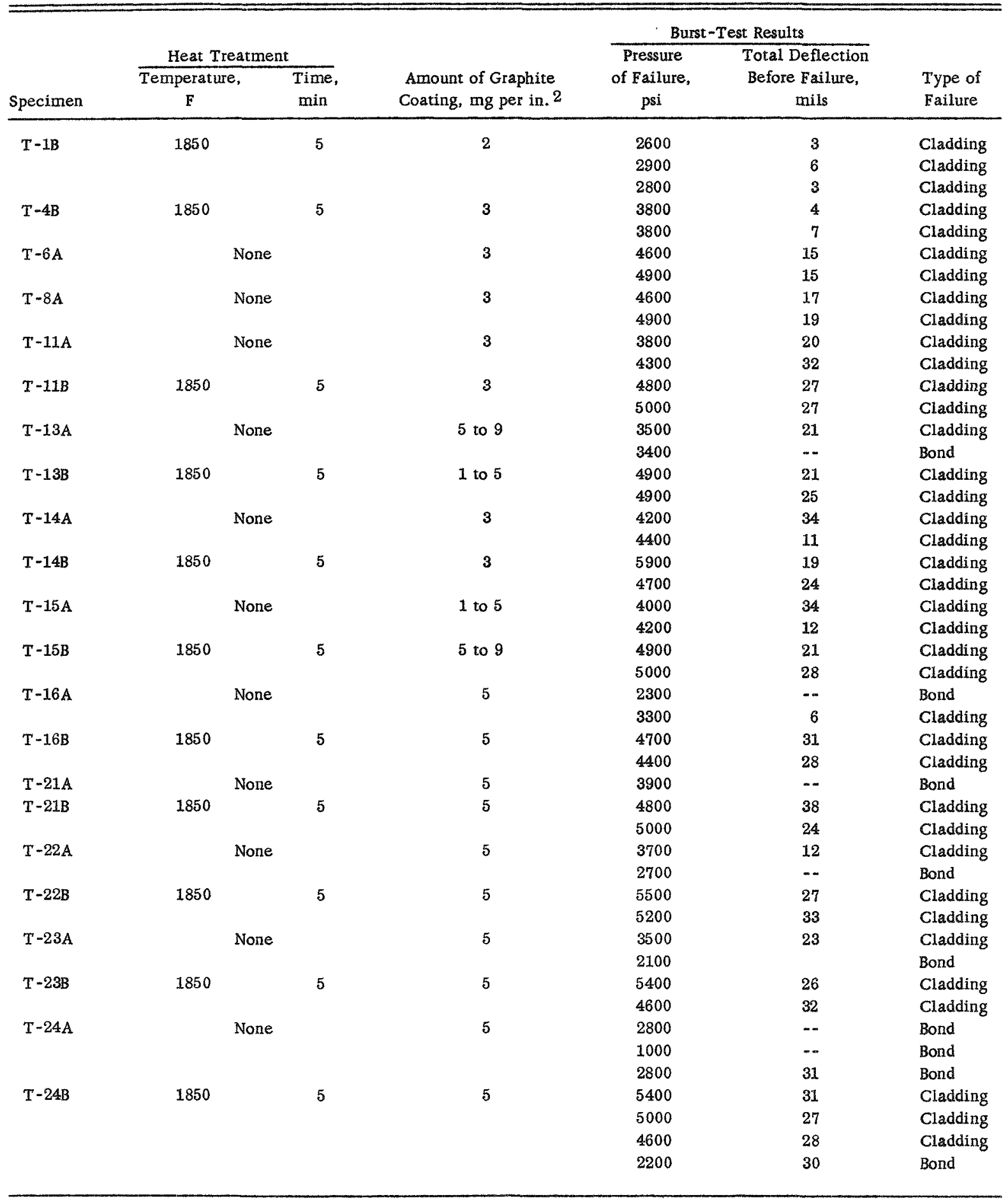


TABLE 27. (Contrnued)

\begin{tabular}{|c|c|c|c|c|c|c|}
\hline \multirow[b]{3}{*}{ Specimen } & \multirow{2}{*}{\multicolumn{2}{|c|}{ Heat Treatment }} & \multirow[b]{3}{*}{$\begin{array}{l}\text { Amount of Graphite } \\
\text { Coarung, mg per in. }\end{array}$} & \multicolumn{2}{|c|}{ Burst $-T$ Test Results } & \multirow[b]{3}{*}{$\begin{array}{l}\text { Type of } \\
\text { Fallure }\end{array}$} \\
\hline & & & & \multirow{2}{*}{$\begin{array}{c}\text { Pressure } \\
\text { of Fallure, } \\
\text { psi }\end{array}$} & \multirow{2}{*}{$\begin{array}{c}\text { Total Deflection } \\
\text { Before Fallure, } \\
\text { mils }\end{array}$} & \\
\hline & $\begin{array}{c}\text { Temperature } \\
\text { F }\end{array}$ & $\begin{array}{l}\text { T1me, } \\
\text { min }\end{array}$ & & & & \\
\hline \multirow[t]{4}{*}{$T-26 \mathrm{~A}$} & \multicolumn{2}{|c|}{ None } & \multirow[t]{4}{*}{5} & 3600 & 10 & Cladding \\
\hline & & & & 3500 & 8 & Cladding \\
\hline & & & & 3400 & 8 & Cladding \\
\hline & & & & 3500 & 10 & Cladding \\
\hline \multirow[t]{3}{*}{$T-26 B$} & \multirow[t]{3}{*}{1850} & \multirow[t]{3}{*}{5} & \multirow[t]{3}{*}{5} & 2500 & -- & Bond \\
\hline & & & & 1000 & -- & Bond \\
\hline & & & & 5300 & 26 & Cladding \\
\hline \multirow[t]{2}{*}{$T-28 \mathrm{~A}$} & \multirow{2}{*}{\multicolumn{2}{|c|}{ None }} & \multirow[t]{2}{*}{5} & 4000 & 27 & Cladding \\
\hline & & & & 4000 & 12 & Cladding \\
\hline$T-28 A$ & 1850 & 5 & 5 & 5300 & 27 & Cladding \\
\hline & & & & 5500 & 27 & Cladding \\
\hline $\mathrm{T}-29 \mathrm{~A}$ & & & 5 & 3100 & $\ldots$ & Bond \\
\hline & & & & 3300 & 16 & Bond \\
\hline$T-29 B$ & 1850 & 5 & 5 & 5900 & 32 & Cladding \\
\hline & & & & 5100 & 29 & Cladding \\
\hline $\mathrm{T}-30 \mathrm{~A}$ & & & 5 & 3700 & 11 & Cladding \\
\hline & & & & 4200 & 4 & Cladding \\
\hline$T-30 B$ & 1850 & 5 & 5 & 5700 & 24 & Cladding \\
\hline & & & & 5300 & 21 & Claddnng \\
\hline $\mathrm{T}-34 \mathrm{~A}(\mathrm{a})$ & & & 5 & 2400 & - & Bond \\
\hline & & & & 2600 & -- & Bond \\
\hline$T-34 B(a)$ & 1850 & 5 & 5 & 5400 & 32 & Cladding \\
\hline & & & & 5100 & 28 & Cladding \\
\hline$T-35 A(a)$ & & & 5 & 2500 & $\cdots$ & Bond \\
\hline & & & & 2200 & $\ldots$ & Bond \\
\hline$T-35 B^{(a)}$ & 1850 & 5 & 5 & 5700 & 23 & Cladding \\
\hline & & & & 5100 & 36 & Cladding \\
\hline$T-36 A$ & & & 5 (buffed) & 3700 & 15 & Cladding \\
\hline & & & & 3700 & 11 & Cladding \\
\hline & & & & 3600 & 12 & Cladding \\
\hline & & & & 3700 & 16 & Cladding \\
\hline & & & & 3700 & 14 & Cladding \\
\hline & & & & 3700 & 9 & Cladding \\
\hline$T-36 B$ & 1850 & 5 & 5 (buffed) & 4900 & 39 & Cladding \\
\hline & & & & 4800 & 37 & Cladding \\
\hline$T-37 A$ & & & 5 (buffed) & 3800 & 17 & Cladding \\
\hline & & & & $410 \mathrm{C}$ & 12 & Cladding \\
\hline & & & & 3800 & 18 & Cladding \\
\hline & & & & 4100 & 7 & Cladding \\
\hline$T-37 \mathrm{~B}$ & 1850 & 5 & 5 (buffed) & 5800 & 28 & Cladding \\
\hline & & & & 5200 & 37 & Cladding \\
\hline$T-88 \mathrm{~A}$ & & & 5 (buffed) & 3700 & 17 & Cladding \\
\hline & & & & 3800 & 18 & Cladding \\
\hline & & & & 3700 & 14 & Cladding \\
\hline & & & & 3600 & 15 & Cladding \\
\hline$T-38 B$ & 1850 & 5 & 5 (buffed) & 5100 & 35 & Cladding \\
\hline & & & & 5200 & 31 & Cladding \\
\hline$T-39 A$ & & & None & 4300 & 14 & Cladding \\
\hline & & & & 4300 & 24 & Cladding \\
\hline & & & & 4300 & 17 & Cladding \\
\hline & & & & 4600 & 12 & Claddung \\
\hline & & & & 4100 & 19 & Cladding \\
\hline & & & & 4100 & 13 & Cladding \\
\hline $\mathrm{T}-39 \mathrm{~B}$ & 1850 & 5 & None & 5400 & 25 & Cladding \\
\hline & & & & 4500 & 34 & Cladding \\
\hline
\end{tabular}

(a) Zurcaloy bonding surfaces were purposely smeared with graphite. 
of graphite during as sembly. These elements (T-34 and T-35 in Table 27) both exhibited intercompartmental leakage in the as-bonded condition but not after an additional $1850 \mathrm{~F}$ heat treatment for $5 \mathrm{~min}$; these results indicated behavior characteristic of the other failed specimens. Metallographic examinations, which revealed a similar comparison with regard to bond-line contamination, are discussed in the next section.

Based on the evidence that graphite contamination of the bond interface had caused the weak bonds that failed during burst testing, four specimens were prepared to attempt to eliminate this defect. Three of these specimens were bonded containing cores which were spray coated with graphite using Aquadag and outgassed, as had been done for the previous elements. A buffing treatment, which was described earlier in this section, was then incorporated into the preparation of the coated cores for these three elements in order to remove loose graphite. The fourth element was prepared with cores that had not been graphite coated so that graphite would not be present in the element. Contamination of the bonds in this element would have indicated that graphite was not the single cause of the bond weakness in these elements. These elements were handled very carefully in an attempt to avoid any bond-line contamination. The results of the burst tests of these elements $(\mathrm{T}-36, \mathrm{~T}-37, \mathrm{~T}-38$, and $\mathrm{T}-39)$ are contained in Table 27. A total of 20 compartments in the three elements containing the buffed graphite-coated cores were burst tested in the as-pressure-bonded condition and after the additional $1850 \mathrm{~F}$ heat treatment, and no bond failures occurred. Burst tests of eight compartments in the element with uncoated cores resulted in no bond failures. Results of the metallographic examination, which revealed good bonds, are discussed in following paragraphs. Thus, based on a small number of elements, buffing of the sprayed-graphite coatings on the cores eliminated the problem of failure of graphitecontaminated bonds during burst testing.

Metallographic Examination

Sections from the elements were examined metallographically to determine the quality of the bonds and the extent of core-cladding reaction. With regard to reaction between the cladding and the graphite-coated cores, no uranium-zirconium reaction zones were visible in any of the sections, indicating that the graphite coatings on the cores had minimized reaction. A representative area of an interface between the cladding and a graphite-coated core is illustrated in Figure 50. Zones of oxygen-rich Zircaloy were observed, however, in some areas around some of the cores which suggested that slight reaction had occurred. These zones were most prevalent at the edges and corners of cores where the graphite coating was the thinnest. Figure 51 shows corners of two graphite-coated cores in an $1850 \mathrm{~F}$ heat-treated specimen; one of the corners has an adjacent zone of alpha grains in the otherwise prior-beta structure of the Zircaloy. The existence of alpha grains after the $1850 \mathrm{~F}$ heat treatment was apparently a result of the raising of the alpha-to-beta transformation temperature due to the high oxygen-content of the Zircaloy. The small elements bonded in the preliminary study which had $1 \mathrm{mg}$ per in. 2 of graphite coating had shown such oxygen-rich zones; therefore, the first few large-scale elements were bonded containing cores coated with 2 to $3 \mathrm{mg}$ per in. 2 of surface. This amount of coating still resulted in zones of oxygenrich Zircaloy about 0.001 in. wide in some areas adjacent to the cores. Two elements were then prepared containing cores which had graphite coatings ranging from 1 to 9 $\mathrm{mg}$ per in. 2 to determine the amount necessary to minimize the zones of oxygen-rich Zircaloy. Metallographic examination of these bonded elements showed that coatings 


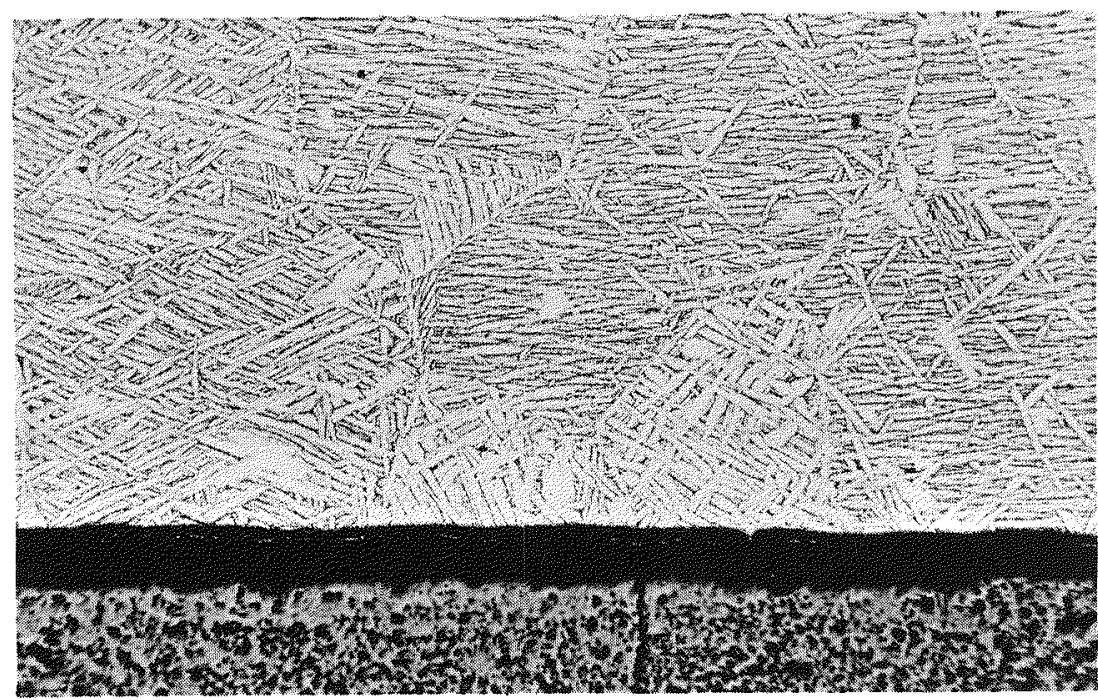

Zircaloy cladding plate

$100 \mathrm{X}$

RM11824

Graphite barrier layer

$\mathrm{UO}_{2}$ core

FIGURE 50. REPRESENTATIVE AREA OF INTERFACE BETWEEN CLADDING AND GRAPHITE-COATED CORE SHOWING NO EVIDENCE OF REACTION

This element contained cores coated with $5 \mathrm{mg}$ of graphite per in. ${ }^{2}$ of core surface and was pressure bonded at $1550 \mathrm{~F}$ and $10,000 \mathrm{psi}$ for $4 \mathrm{hr}$ and heat treated at $1850 \mathrm{~F}$ for $5 \mathrm{~min}$.

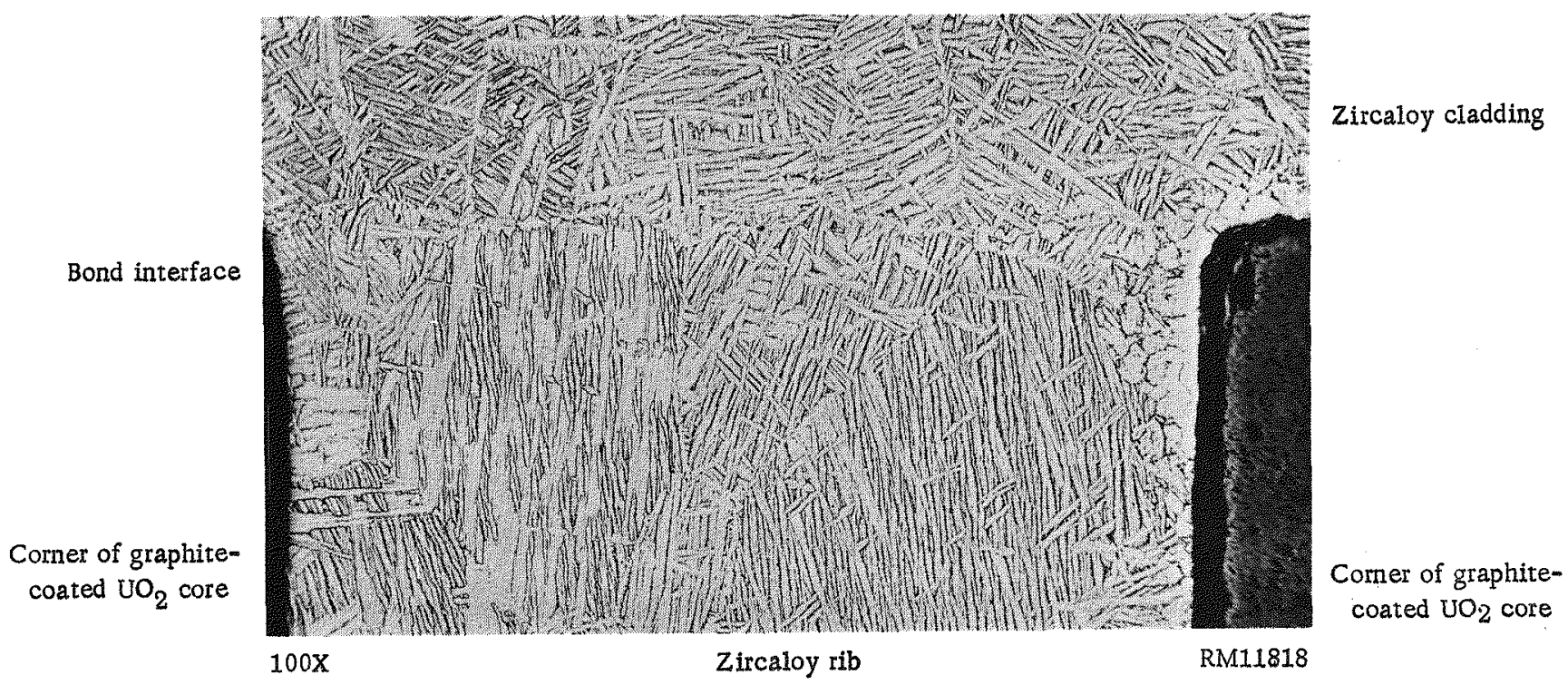

FIGURE 51. TWO CORNERS OF GRAPHITE-COATED CORES, ONE OF WHICH HAS AN ADJACENT ZONE OF ALPHA GRAINS IN THE ZIRCALOY INDICATING SLIGHT CORE-CLADDING REACTION

Note the alpha grains in the otherwise prior-beta zircaloy structure at comer of core on the right, indicating a zone of oxygen-rich Zircaloy. Such zones had no apparent adverse effect on the corrosion behavior of purposely defected compartments. This element contained cores coated with $3 \mathrm{mg}$ of graphite per in. 2 of core surface and was pressure bonded at $1550 \mathrm{~F}$ and $10,000 \mathrm{psi}$ for $4 \mathrm{hr}$ and heat treated at $1850 \mathrm{~F}$ for $5 \mathrm{~min}$. 
of $5 \mathrm{mg}$ per in. 2 and greater appeared to be effective barriers. With these thicker coatings, the zones of oxygen-rich Zircaloy were restricted to narrow bands in only a few scattered areas, principally at corners of cores. Subsequent elements, prepared with coatings from 5 to $6 \mathrm{mg}$ per in. 2 , yielded similar results. In the final set of elements in this series in which the graphite-coated cores $\left(5 \mathrm{mg}\right.$ per in. ${ }^{2}$ ) were buffed before assembly, as discussed elsewhere, the amount of oxygen-rich Zircaloy was further reduced, apparently due to improved quality and uniformity of the coating present. As noted earlier, the results of the corrosion tests of purposely defected compartments showed that the oxygen-rich Zircaloy zones had no deleterious effect on corrosion behavior.

Small spherical voids had been observed in the preliminary series of specimens, indicating entrapped residual helium or entrapped air in the element. The first four large-scale elements were sealed by a helium-shielded arc after a prolonged evacuation. The final weld was applied as quickly as possible in an attempt to obtain a small partial pressure from the atmosphere with a minimum amount of helium introduced into the element. Metallographic examination of the bonds obtained with these elements still revealed the presence of small spherical voids, and it became apparent that the elements would have to be sealed while being evacuated. Two techniques were developed for accomplishing this; these techniques were described in the section on the preparation of this series of elements. Subsequent elements were sealed containing a vacuum by resistance-upset welding or induction-welding techniques, both of which proved to be satisfactory. Examination of the bonds in these evacuated elements showed that the characteristic bond-line voids had been eliminated.

Zones of alpha grains of Zircaloy were observed along some of the bonds in some of the beta-heat-treated specimens, indicating areas of high oxygen content. The location of these zones was not restricted to any particular area of the element, nor could they be correlated with any known process variable. Such zones were not present in the specimens which had buffed graphite-coated cores, however. The oxygen could have originated from core-graphite or core-cladding reaction, core outgassing, adsorbed moisture on cor $\in S$, entrapped air, or the Zircaloy itself.

Elements containing cores which had been spray coated with 5 to $6 \mathrm{mg}$ of graphite per in. ${ }^{2}$ of core surface and had not been buffed were observed metallographically to have bond-line contamination in some areas and resulting lack of grain growth across the interface. The bonds in these elements in the as-pressure-bonded condition averaged about 50 per cent Type $A$ and 50 per cent Type C, classified according to Figure 3. Thus, about half of the bond areas did not exhibit grain growth across the interface, indicating that the bonds would be weak in those areas. The amount of grain growth across the interface was improved by the $1850 \mathrm{~F}$ heat treatment; however, the problem was not eliminated in areas which apparently had relatively large amounts of bond-line contamination. These bonds were classified, on the average, as 70 per cent Type A, 10 per cent Type B, and 20 per cent Type C. These observations correlated with the failures of weak bonds in the elements during burst testing, which was discussed previously. Examination of these bonds in the electron microscope confirmed that the defective areas contained contamination, rather than voids. The contaminant was positively identified as graphite by X-ray diffraction. Contaminated bond areas which were examined by this technique disclosed the zirconium carbide phase, which had been shown to be the product formed during pressure bonding by the Zircaloy cladding and the graphite from the coated cores. Also, in other studies, metallographic examination has 
shown that a graphite film only 200 A thick on Zircaloy bonding surfaces can prevent bonding. (7) To further confirm the adverse effect of graphite in the bond interfaces, the two elements having bonding surfaces intentionally smeared with graphite, which were described in connection with the burst-test results, were prepared. Metallographic study of the bonds in these elements showed bond-line contamination similar in appearance to that observed in the other elements containing weak bonds.

Based on the establishment of graphite as the cause for weak bonds, four elements were prepared in an attempt to avoid this bond-line contamination. These elements were described in the discussion of the burst-test results; three of the elements contained cores which were spray coated with graphite and buffed to remove loose graphite, and the fourth contained uncoated cores. The bonds in these elements were examined metallographically for contamination and extent of grain growth across the bond interface. The bonds averaged greater than 90 per cent Type A, classified according to Figure 3. The remaining 10 per cent or less of the bond areas were generally Type $C$ in the as-bonded elements and Type B in the $1850 \mathrm{~F}$ heat-treated elements. Representative areas of good bonds in these elements are shown in Figures 52 and 53 for asbonded and heat-treated elements, respectively. The bonding in these elements, therefore, was considered to be good metallographically; the burst results showed the bonds to be consistently strong. Bond-line contamination in these elements was significantly reduced to an apparently acceptable level; very small dots of contaminant were observed in only a few areas of the bonds in the four elements. Since these small dots were present in the element with uncoated cores, the contamination must have originated from the $\mathrm{UO}_{2}$ cores or the Zircaloy bonding surfaces. It was concluded that the buffing treatment performed on the graphite-coated cores significantly improved the bond quality in this limited number of elements.

The results of this process-development study indicated that with regard to bond strength, corrosion resistance, compartment integrity, cladding ductility and strength, and dimensional control, satisfactory elements could be produced by gas-pressure bonding utilizing the edge-welding technique, piece-component picture frames, and cores sprayed with a graphite coating and buffed. 


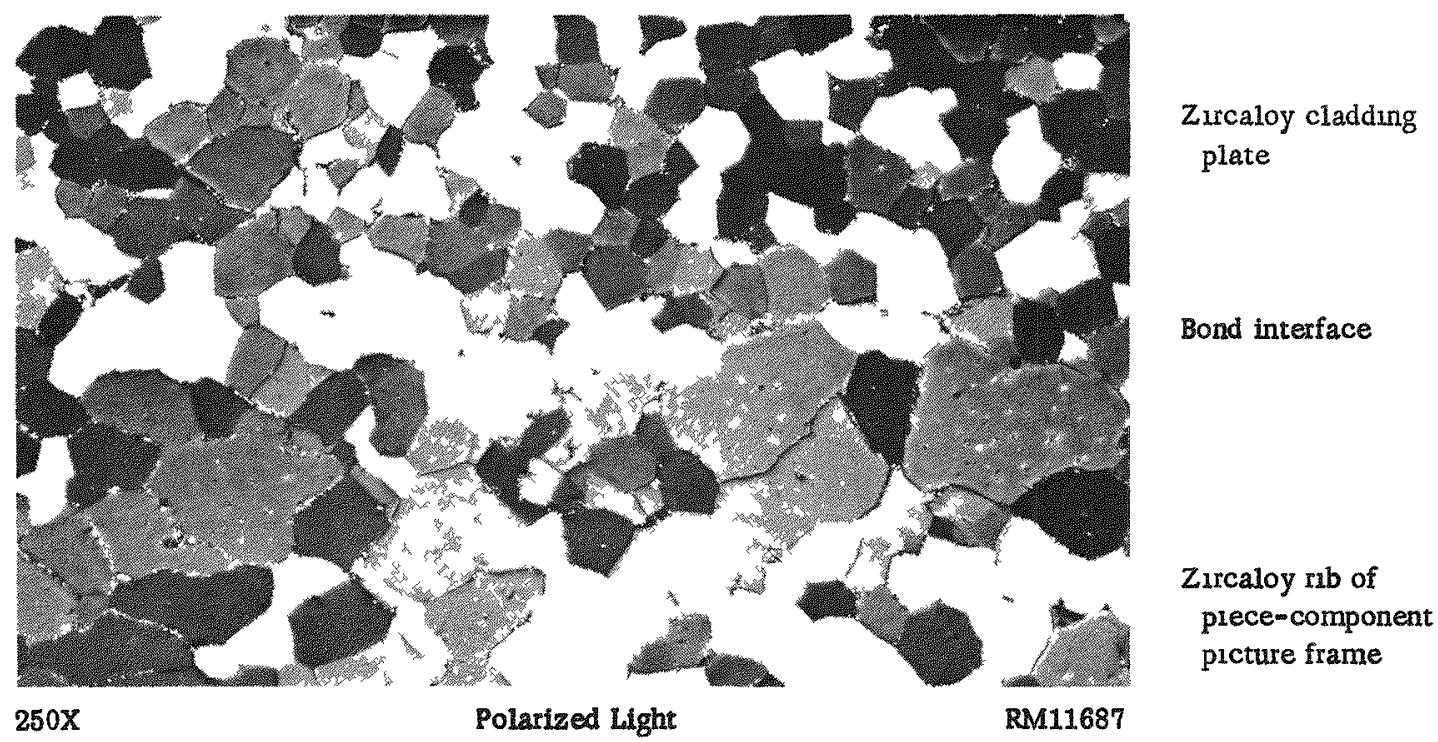

FIGURE 52. ZIRCALOY-TO-ZIRCALOY BOND IN AS-PRESSURE-BONDED ELEMENT WHICH WAS PREPARED UTILIZING THE EDGE-WELDING TECHNIQUE, PIECE-COMPONENT PICTURE ERAME, AND BUFFED GRAPHITE-SPRAYED CORES

Thus element was pressure bonded at $1550 \mathrm{~F}$ and 10,000 psi for $4 \mathrm{hr}$. Note that the approximate location of the bond interface can be observed by the difference in gram size of the components, which originated in the different materials from which the various components were prepared.

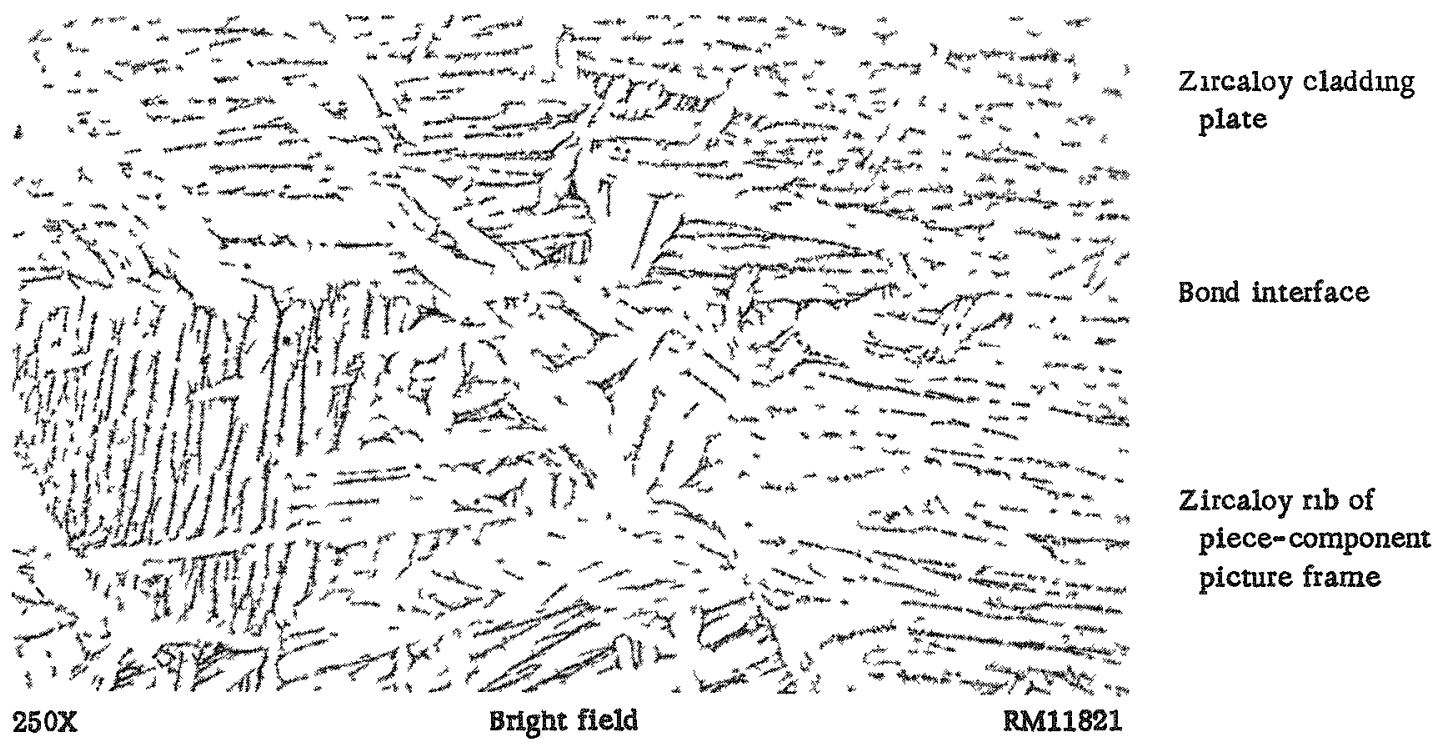

FIGURE 53. ZIRCALOY-TO-ZIRCALOY BOND IN 1850 F HEAT-TREATED PORTION OF ELEMENT SHOWN IN FIGURE 52

Subsequent to pressure bonding, this portion of element was heat treated for 5 min in an $1850 \mathrm{~F}$ salt bath. 


\section{SUMMARY AND CONCLUSIONS}

The gas-pressure-bonding technique appears to be a feasible method for the preparation of Zircaloy-clad flat-plate uranium dioxide fuel elements. A solid-state bond is achieved between the Zircaloy picture frame and the cladding without fragmentation of the brittle uranium dioxide cores if reasonable tolerances are maintained. The most satisfactory pressure-bonding conditions for this type of fuel element consist of bonding at $1550 \mathrm{~F}$ and 10,000 psi for $4 \mathrm{hr}$. Procedures have been developed for preparing the various components that result in excellent metallurgical bonding in the as-bonded condition. An additional heat treatment for $5 \mathrm{~min}$ in a salt bath at $1850 \mathrm{~F}$ subsequent to pressure bonding serves to induce increased grain growth across the bond interface and to strengthen the bonds in specimens containing components which have not received the optimum type of preparation. This heat treatment does not remove bond-line contamination, however. In production, the additional heat-treating operation would be costly and could introduce problems with surface contamination and dimensional control. The results of this problem indicate that the heat treatment is not necessary when the components for the elements are prepared according to developed techniques; new studies have been initiated to confirm these results.

Since bonding is achieved with a minimum amount of deformation, the quality of the bonds is primarily dependent on the method used to prepare the surfaces of the Zircaloy. Studies concerned with the evaluation of various surface preparations have indicated that the best bonds are obtained with treatments such as machining and abrading that expose new metal and produce a disturbed and roughened surface layer. Machine belt abrading is favored because more consistent bonds have been obtained with Zircaloy prepared by this process, and because it is relatively inexpensive.

Extensive reaction occurs when bare uranium dioxide cores are gas-pressure bonded at 1450 to $1550 \mathrm{~F}$. Barrier materials such as graphite and chromium were effective in preventing reaction during pressure bonding and beta heat treating. The corrosion resistance of purposely defected compartments in elements containing cores with properly applied coatings of graphite and chromium were found to be satisfactory. Graphite may be more preferable, based on coating methods available at the present time, because it is easier to apply and lower in cost. Techniques have been developed to provide consistent protection of the cores during bonding and heat treating by spray coating the cores with 5 to $6 \mathrm{mg}$ of graphite per in. ${ }^{2}$ of core surface. These coatings are then outgassed and buffed, removing about $0.5 \mathrm{mg}$ of graphite per in. ${ }^{2}$ to prevent contamination of the bonds. A new study has been initiated to attempt to develop a satisfactory and economical method for coating the cores with chromium, since a metallic barrier would probably require less careful handling of the coated cores. A method for coating the cores with crystalline carbon is also being investigated which may be more economical and produce better-quality coatings than sprayed graphite.

Two techniques for the assembly of the elements have been investigated in this program. In the first technique, the cladding components and cores and accompanying Ti-Namel spacers are assembled into a protective stainless steel or Ti-Namel containe $r$ which is evacuated, sealed, and then pressure bonded. To limit contamination of the Zircaloy cladding by the Ti-Namel spacers, stainless steel shims are placed between them as a barrier. The second technique involves fusion welding the edges of the picture frame and cladding plates in a helium-atmosphere tank. Methods have been developed for accomplishing the final seal while the element is under evacuation. 
The edge-welding technique is preferred, since it eliminates some of the problems encountered with the elements bonded in containers, such as diffusion of iron into the Zircaloy and poor bonds at the extreme edges of the element. The use of a compartment picture frame consisting of strip components instead of a one-piece punched frame is desirable because of its economic advantage. The optimum design for elements with compartmented piece-component picture frames employed transverse ribs the width of one $\mathrm{UO}_{2}$ core, and longitudinal ribs the total length of the fuel which fit flush to the unnotched top and bottom plates.

A method of loading the edge-welded elements into the high-pressure autoclave for gas-pressure bonding has been developed which prevents warpage of the elements and satisfactorily minimizes contamination of the Zircaloy cladding by the autoclave gas.

Waterlogging of the compartments in these specimens was encountered even though a minimum of void space is present in elements prepared by gas-pressure bonding. This effect seems to be inherent with this type of fuel element. A problem encountered with these specimens which has not received a final solution is the excessive flow of the cover plates into void spaces in the picture-frame resulting from fuel which has been chipped or from poor dimensional control of the components. Determination of a method for minimizing this effect and determination of the maximum allowable void space in the assembled fuel plate are being attempted in a new program.

The most feasible process for gas-pressure bonding these fuel elements, therefore, consists of assembling belt-abraded piece Zircaloy components to form the compartmented picture frame, inserting buffed sprayed-graphite-coated cores into the compartments, fusion welding the edges of the picture frame and cladding plates, evacuating and sealing the element, gas-pressure bonding at $1550 \mathrm{~F}$ and 10,000 psi for $4 \mathrm{hr}$, and heat treating for $5 \mathrm{~min}$ at $1850 \mathrm{~F}$ to improve bonding.

\section{ACKNOWLEDGEMENT}

This work was sponsored by the Bettis Atomic Power Division of Westinghouse Electric Corporation. The authors are grateful to Dr. B. Lustman and Mr. E. Losco of Bettis for their cooperation and assistance during the course of this research.

\section{REFERENCES}

(1) "Pressurized Water Reactor (PWR) Project Technical Progress Report for the Period August 24, 1956, to October 23, 1956", WAPD-MRP-64 (October 23, 1956).

(2) "Pressurized Water Reactor (PWR) Project Technical Progress Report for the Period October 24, 1956, to December 23, 1956", WAPD-MRP-65 (December 23, 1956). 
(3) "Pressurized Water Reactor (PWR) Project Technical Progress Report for the Period February 24, 1957, to April 23, 1957", WAPD-MRP-67 (April 23, 1957).

(4) Mallett, M. S., Gerds, A. F., Lemmon, A. W., and Chase, D. L., "The Kinetics of the Zirconium-Uranium Dioxide Reaction", BMI-1028 (August 15, 1957).

(5) Bean, C. H., Macherey, R. E., and Lindgren, J. R., "Roll-Cladding UraniumZirconium and Uranium-Zirconium-Niobium Alloys With Zircaloy 2 for PlateType Fuel Elements", ANL-5628 (February, 1958).

(6) Paprocki, S. J., Hodge, E. S., Boyer, C. B., and Getz, R. W., "Gas-Pressure Bonding of Flat-Plate Fuel Assemblies", BMI- 1312 (January 20, 1959).

(7) Paprocki, S. J., Hodge, E. S., and Gedwill, M. A., Jr., Unpublished Work. 